\title{
A Text Book OF
}

\section{Agricultural ENTOMOLOGY}

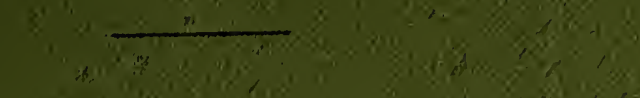

\section{fis $x^{2}$}

\section{$3 y$. wis}

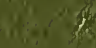

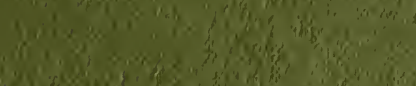




$$
\text { - }
$$




Arith

Sompliments

furm

A TEXT-BOOK

OF

AGRICULTURAL ENTOMOLOGY. 


\section{LONUON :}

WEST, NEWMAN AND CO., PRINTERS,

54, HATTOX GARDEÁ, E.C.

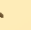




\section{$5 A$ \\ 73 \\ $073 t$ A TEXT-BOOK \\ OF \\ AGRICULTURAL ENTOMOLOGY;}

BEING

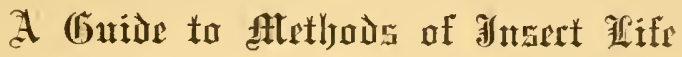

AND MEANS OF

\section{PREVENTION OF INSECT RAVAGE.}

FOR THE USE OF

Ggriculturists and Ggricultural ミtuonts.

BY

ELEANOR A. ORMEROD, F.R. Met. Soc., \&c.

LATE CONSULTING ENTOMOLOGIST OF THE ROXAL AGRICULTURAL SOCIETY OF ENGLAND, ANI

HON. MIEMBER OF FARMERS' CLUB; HON, AND CORR. MEM. OF ROYAL AG. AND HORT. SOC.,

S. AUSTRAila; HON. MEM. OF ENT. SOC. OF ONTARIO, AND CORR. MIEMBER OF

FIELd NAT. CLUB OF OTTAWA, CANADA; MEMBER OF EASTERN PROVINCE

NATURALISTS' SOC., CAPE COLONY;

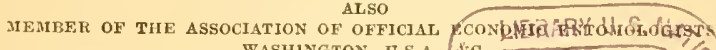

WASH1NGTON, U.S.A.,

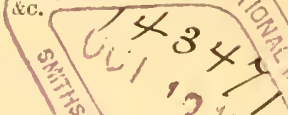

SECOND EDITION.

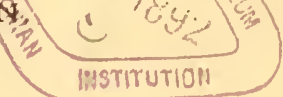

L O N D O N :

SIMPKIN, MARShaLL, imamLTON, KeN' \& CO., Lmited. 
Strive on, and if a shadow fall

To dim your forward view, Think that the sun is over all, And will shine forth anew. Disdain the obstacles ye meet, And to one course adhere ; Advance with quick, but cautious feet; Hope on, and persevere.

J. Crutchley Prince. 


\section{THE MANT FRIENDS}

TO WHON I AM INDEBTED FOR HELP AND ENCOURAGEMENT IN MY WORK

This Ilittle Dolume

IS G R A T E F U L L Y IN S C R I B E D

$B Y$

TH E W R T E R. 



\section{PREFACE.}

THe first edition of this little volume consisted of ten lectures delivered in 1883 at the Institute of Agriculture of South Kensington, in compliance with the request of the Director that I would prepare some simple and plain information regarding the methods of life of crop insects, and means of prevention of their ravages, such as might be of service to school teachers.

At that time there appeared to be but little call for such a compilation, but I complied with the request in the hope that the work might be useful for farm service; and that in its published form it might be carried to the field, or taken up at an odd minute, and give a little information without burdening the realer with a need of looking elsewhere for explanations.

The work, however, appeared likely to remain nearly useless, until, in the course of last year, 
attention was drawn to it as conveying information in one of the branches of agricultural instruction brought forward under the arrangements of the new County Councils, and the little book sold off so rapidly as to necessitate the preparation of a Second Edition, which, under the circumstances, is now issued under a slightly altered and more appropriate title.

Since 1884 (the date of the first edition), knowledge of the habits of our farm insects, and also knowledge of how to cope with them, has made great adrance, and some of the most important of these points hare been alluded to. Amongst these, orchard fruitgrowing, as a distinct agricultural industry, is almost a new branch; and in its train has come, from across the Atlantic, mucl useful knowledge as to insecticides, and implements for their application. Great adrance has also been made in information regarding habits of some of our commonest cattle insects, and notes are given in the following pages on these subjects, as well as on injurious representatives of rarious other families as the Sheep Liver Flulie, Eelworms, Slugs, itc.

'The reader' is, however, begged to observe that this little book is in no way offered as a "Manual," but. 
literally as a "Guide,"-a means of leading the student onwards to a knowledge of some of the fixed laws of insect life, which we may always rest on as the foundation of serviceable preventive measures. Descriptions of some of our infestations are given as. characteristic of methods of injury, which may be caused in some instances by one lind of insect in one stage of its life, or by some in every stage, or again in the larval or in the perfect state. These are necessarily for the most part taken from our best known attacks, but they are giren simply as examples of classes of methods of destruction falling (hoverer caused) under special classes of remedies.

As before, I have where possible used English rather than scientific terms, and for the explanation of such scientific terms as are necessarily made use of, the reader is referred to the Glossary. For the same reason (that is, as far as possible to avoid burdensome technical description of the appearance of the insects noticed), figures liave been given in all cases where they were procurable, and the scientific names of these are giren, in ease they may be required, in the "List" at 11). xiii-svi. 
Of these figures (163 in all), upwards of 57, used by courteous permission of Messrs Blackie \& Son, Glasgow, N.B., are from the well-known figures by John Curtis, given in his 'Farm Insects'; and 10 figures of Moths from Newman's 'British Moths,' are inserted by permission of Messrs. Allen \& Co. The figures of the Hop Aphis and American Blight Aphis are copied from diawings by Mr. G. B. Buckton, F.R.S., in his 'British Aphides'; and the figure of the Bee Parasite and Forest Fly, as well as two others of which the source is acknowledged accompanying, are after drawings by Prof. Westwood. The figure of Turnip Sawfly caterpillars, and a few others, are inserted by permission of Mr. T. P. Newman.

About 54 of the figures are mainly from life, in some instances drawn by myself, but for the most part by Mr. Horace Knight, artist to Messrs. West, Newman of Co. Of the remainder I think the source will be found, for the most part, to be acknowledged either beneath the figure or in the context, as, for instance, in the case of the Liver Fluke, duly acknowledged as from the paper of Prof. A. P. Tho nas, and the Stem Eehworms, copied by lind permission of Dr. J. Ritzema Bos. 
In the entomological arrangement I have mainly followed that laid down by Prof. J. O. Westwood in his 'Introduction to the Modern Classification of Insects,' and in mentioning this I camnot refrain from also acknowledging the deep obligation I am under to my much respected friend and honoured master in the study of Entomology, not only for the information derived from his published works, but for the scientific aid which, in correspondence and in occasional meetings, has extended orer a large portion of a life-time.

In the special sections, I have endeavoured to follow the lines laid down by our leading specialists, as in 'British Beetles,' by the late E. C. Rye; 'British Aphides,' by G. B. Bucliton, F.R.S.; and others of similar known standing. In the practical part, I have endeavoured to work out the teaching which appears to me to be conveyed by the observations which now, for many years, lave been placed in my hands by agriculturists throughout our country; and should this little book prove of agricultural scrvice, I much desire to point out that this will be not from speculative or theoretical views, but in great part from the 
plain statement, given by observant farmers, of what treatment answers.

For myself I only wish I could have done my part better, but I have earnestly tried to make it correct and clear, and it will be a great satisfaction to me if it should prove of use.

\section{ELEANOR A. ORMEROD, \\ Late Consulting Entomologist of the Tioyal Agricultural Society of England.}

Torrington House, St. Albans, July $26 t h, 1892$. 


\section{LIST OF ENGRAVINGS ON WOOD.}

The description being given with the English name to each figure, the scientific name alone is given in the following List.

\section{CHAPTER I.}

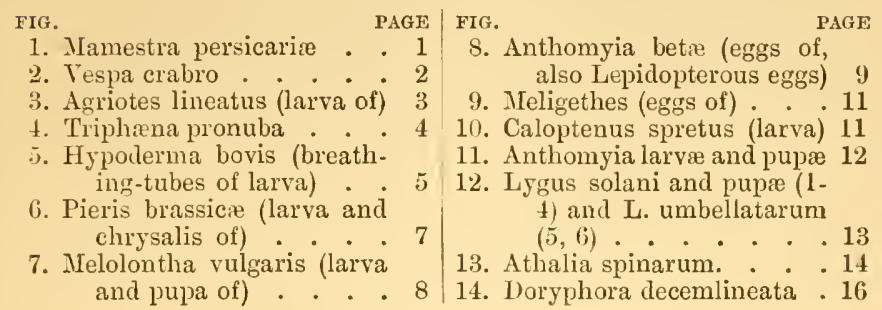

\section{CHAPTER II.}

15. Zabrus gibbus. . . . 17

16. Agrotis exclamationis . . 18

17. Apion (larva and pupa). . 19

18. Cynips kollari (larva and pupa). . . . . 20

19. Hylemyia coarctata . . 21

20. Eupteryx solani . . . 22

21. Sesia bembeciformis . . . 24

22. Psila rose . . . . . . 27

23. Pulex irritans . . . . 28

21. Tenebrio molitor . . . . 28

25. Pygæra bucephala. . . . 29

26. Pieris brassica. . . . . 29
27. Bombus lucorum (1) and B. terrestris (4). . . . 30

28. Athalia spinarum. . . 30

29. Caloptenus spretus . . . 31

30. Forfieula sp. . . . . . 32

31. Aphis brassice. . . . . 32

32. Miris dolabratus (1-4) and II. tritici $(5,6)$. . . 33

33. Thips cerealium (1-4) and

T. minutissima (5-8) . 33

34. Mormonia nigromaculata . 34

35. Stylops spencii. . . . . 34

36. Chrysopa perla. . . . 34

\section{CHAPTER III.-DIPTERA.}

37. Tipula oleracea . . . . 36 43. Anthonyia ceparum. . 49

38. Trichocera hiemalis. . . 38 4t. Diysophila flava . . . 50

39. Cecidomyia tritici . . 42 45. Anthomyia betæ . . . . 51

40. " destructor . . 4446 . ," brassice (1-3),

41. Barley-stem infested by $\mathrm{C}$. destructor . . . . 45

42. Puparia of C. destructor . 46
A. radicum $(4,5)$ and $\mathrm{A}$. tuberosa $(6-9)$. . . . 53 


\section{CHAPTER IV.-DIPTERA.}

FIG.

PAGE $\mid$ FIG.

47. Hylemyia coaretata . . 57

48. Chlorops treniopus $(1,6,11)$

and Colinius niger $(7,8) 59$

49. Tabanus bovinus. . . 63

50. Gastrophilus equi. . . . 65

51. , , , (eggs of) 66

52. $\quad, \quad, \quad$ (magrots of)". . . . . . 67

53. Hypoderma bovis. . . . 67

54. ,, ,, (mouthforks of maggot) . . 68

55. Hypoderma bovis (trachere of maggot) . . . . 68

56. Hypoderma bovis (muscles of maggot) . . . . 69

57. Hypoderma bovis (prickles of maggot) • . . . . 69

58. Hypoderma bovis (section of warble of) . . . 69

59. Hypoderma bovis (hide warbled by). . . . 70

60. Estrus (Cephalemyia) ovis 75

(11. Hippobosca equina . . 77

62. Melophagus ovinus . . 78

63. Pulex irritans (Aphaniptera). . . . . 79

\section{CHAPTER V.-COLEOPTERA.}

64. Melolontha vulgaris . . 80

65. Haltica (Chotocnema) concinna

6i. Carabus granulatus

(i7. Steropus madidus and gnawed Mangold-roots.

(is. Dytiscus marginalis

69. Oxytelus rtigosus $(1,2)$ and O. sculpturalis (3-ti) .

70. Cucujus testaceus $(2-4)$ and Trogosita mauritanica $(5-8)$.
71. Necrophorus ruspator . . 87

72. Neligethes aneus . . 87

73. Silpha opaca . . . . 88

83 74. Anisoplia agricola $(1,2)$ and A. horticola $(3-5)$. 89

84 75. Cetonia aurata . . . . 89

8576 . Melolontha vulgaris (antennæ of) . . . . 90

si 77. Elaters. . . . . . !4

78. Telephorus clypeatus . . 98

7!. Iiyturus tomentosus . . 9!

s6, 80. Xyleborus dispar . . 100

\section{CHAPTER VI.-COLEOPTERA.}

81. Apion apricans $(2-i), 6,7)$ and $A$. assimile . 101

\&.. Balaninus nueum . . 103

83. Anthonomus pomorm 101

81. Sitones crinitus $(1,2)$ and S. lineatus $(3,1) . \quad$. . 106

$8 \%$ Bruchus rufinanus $(1,2$, 4-7) and B. pisi (9, 11) . . . . . .

86. Centorliyneluas sulcicollis. 110 87. Scolytus destructor (workings of) .
88. Hylesinus fraxini (worliings of) . . . . . 113

89. Aromia moshata. . . . 114

90. Crioceris melanopa. : 115

91. Chrysomela (Phiedon) betula. . . . . 116

92. Haltica (Phyllotreta) nemoxum . . . . 116

93. Coccinella (in various stages), C. bipunctata (7), C. dispar (s), and C. septempunctata (9) . 120 


\section{CHAPTER VII.-LEPIDOPTERA.}

FIG.

94. Pieris brassice. 1.20

95. Cossus ligniperda (larva) 123

96. Pieris napi . . . . 124

97. Stauropus fagi (male) . 124

98. Pygæra bucephala. . . 125

99. Pieris lapre . . . . . 126

100. Sphinx (Acherontia)atropos. . . . . 127

101. Smerinthus ocellatus. . 128

102. Sesia benbeciformis . 129

103. " tipuliformis. . . 130

114. Cossus ligniperda . . 131

105. Zeuzera rsculi . . . 132

106. Hybernia defoliaria . 134
FIG. PAGE

107. Cheimatobia brumata . 135

108. Anisopteryx æscularia (eggs) . . . . . 137

109. Orgyia antiøua. . . . 138

110. ,, ," (cocoons of) . . . . . 138

111. Agrotis exclamationis . 141

112. ", segetum . . 141

113. Mamestra brassicr . . 142

114. Charreas graminis and caterpillars . . . 144

115. Plusia gamma . . . 145

116. 'Tortrix viridana . . . 148

\section{CHAPTER VIII.-HYMENOPTERA, \&c.}

117. Lophyrus rufus (and larva) . . . . . 14!

118. Lophyrus pini (larva and pupa). . . . 152

119. Hoplocampa testudinea and larra. . . . . 154

120. Athalia spinarum (larva and pupa). . . . 156

121. Cephus pygmens $(1-5)$ and Pachymerus calcitrator $(8,9)$. . . . 15:7

122. Sirex jurencus . . . 158

123. Cynips kollari (larva and pupa) . . . . . $15 y$

124. Neuroterus lenticularis (galls of) . . . . . 160
125. Aphis (Siphonophora) granaria (1-4), Aphidius arene $(5,6)$, and Ephedrus plagiator ( 7 , 8) . . . . 161

126. Pieris napi (1-4) and Hemiteles melanarius $(5$, (6) . . . . 162

127. Pteromalus puparum(nat. size about one line) . 163

128. Nicroglenes penetrans (1) \& Platygaster tipulæ (2) . . . . . 164 129. Vespa crabro . . . 166 130. Stylops Spencii. . . 166 131. Mormonia maculata . . 167

\section{CHAPTER IX.-HOMOPTERA, \&c.}

132. Aphis rumicis (faba) . . 16!) 133. Euacanthus interruptus. 173 134. Eupteryx solani . . . 174 135. Psylla mali and pupa of

$$
\text { P. pyii. }
$$

136. Aphis brassica . . . 17

137. Fore wing of Aphis (div. of Aphidinæ) . . . 176
138. Aphis floris-rape, Curtis (1-4), and A. rapre, Curtis $(5-8)$. . . . 178 139. A phis (Phorodon) liumuli 180 110.

"base of "antenne "and frontal tubercles of) . 18: 111. Schizoneura lanigera. . 1-3 


\section{CHAPTER IX.-Continued.}

FIG.

PAGE FIG.

112. Chermes laricis. . . 186

1.7. Miris dolabratus (1-4) and

143. abietis . . 187

144. Aleyrodes proletella . . 188

145. Aspidiotus (Mytilaspis) conchiformis . . . 190

146. Lygus solani (1-1) and

L. umbellatarum $(5$,

6) . . . . . 191 M. tritici $(5,6)$. . 191 148. Gryllotalpa vulgaris . . 192 149. Forficula sp. . . . 193

150. Caloptenus spretus . . 194 151. Thrips cerealium (1-4), T. minutissima $(5-8) \cdot 196$ 152. Knapsack pump ? . 197

CHAPTER I.-MOLLUSCA, ANGUILLULIDE, dc.

153. Limax agrestis (1), Limax (Arion) ater $(2,3)$. . 198

154. Limnæus truncatulus (1), L. pereger (2), L. stagnalis (3)

155. Fasciola hepatica .

156. Tylenchus devastatrix .213

157.

158. ", obtusus (1),
159. Tulip-rooted oat plant . 216 160. Julus Londinensis (1), J. guttatus $=$ pulchellus $(2,3)$, J. terrestris $(4)$, Polydesmus complanatus $(6,7)$. . . . 222

101. Tyroglyphus longior . . 221

11i2. Tetranychus telarius. . 225

163. Phytoptus sp. . . . 226 Aphelenchus avenæ '2), Plectus obtusus (3) 215 


\section{G U I D E}

To

\section{METHODS OF INSECT IIFE.}

\section{CH A P T E R I.}

EGGS， CATERPILLARS， \&c.

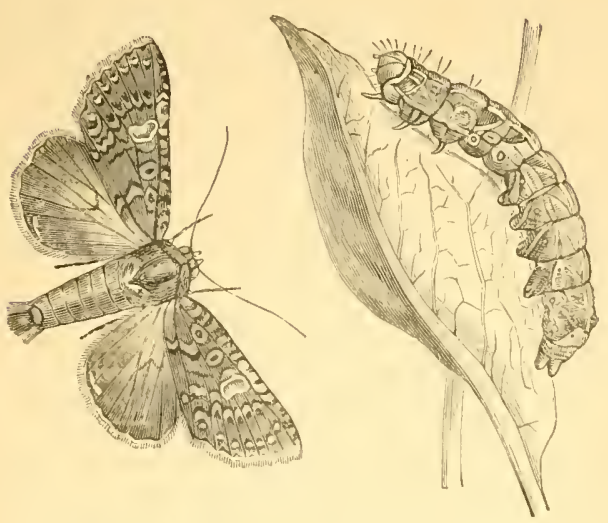

Fig. 1.-Dot Moth (Mamestra persicuria), from life ; caterpillar (after figure of Dr. Taschenbereros).

The first step in the study of insect life is to consider what an insect is; that is, what the special points are by which we may know whether what we are looking at is an insect or not.

We all know in a general way what an insect is : we know that a Wasp or a Fly, a Beetle or a Butterfly, 
is in each case an insect, and that insects begin their lives by being either produced alive or hatched from an egg as maggots or caterpillars, or in some other wingless shape; and that gradually, through various changes in the nature of the inside organs, and changes of appearance caused by moults of the outer skin, they alter to the state of the perfect insect. But without going into very minute details, such as can only be observed with the help of powerful magnifying

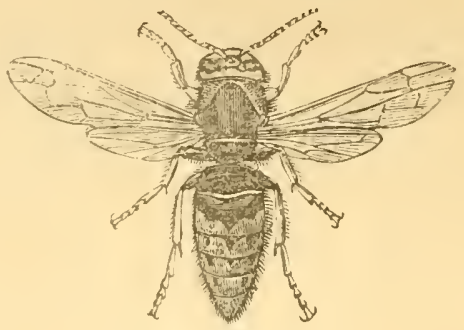

FIG. 2.-Hornet.

glasses, or described by words not generally understood; we know so much of the precise definition of what an insect is as to enable us to distinguish it certainly from spiders, mites, woodlice, julus worms, or other creatures often found in company with insects, and often known as "insect allies."

An insect (in its perfect stage), typically considered, is in-sected on cut into three distinet parts, namely, head, fore borly or thorax, and hinder body or abdomen; the head is furnished with two horns, or antenne, besides eyes, and jaws, or suckers, for feeding purposes; the thorax is commonly supplied with either one or two pairs of wings, and also with three pairs of legs; the abdomen contains the digestive organs, ife. Insects throughout their lives, that is, throughout all their three successive stages,-whether of grul and maggot; or chrysalis; or perfect winged and six-legged creature,-are annulose, that is, are 
formed of a succession of rings or segments; and they do not breathe, as we do, by drawing air through their mouths into their lungs, but by branched tracher, that is, by branched air-tubes running through all parts of the structure, and furnished with little openings at the outer end, mostly along the side of the insect, through which the air supplies are obtained.

Let us go over this point by point. Insects not having any bones, that is not having an inside skeleton, need an outside skeleton or support to keep them together. This is formed of a succession of

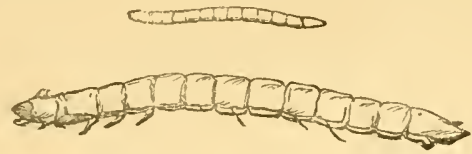

FIG. 3.- Wireworn, nat. size and magnified.

rings or segments, often of a horny texture, as you may see in a Wasp when it has been crushed on a window-pane; and the rings appear to be commonly about thirteen in number. One of these rings * forms the head, the three next support the legs and wings, and the remaining rings or segments form the abdomen, and contain a portion of the organs of digestion and those of reproduction. Thus an insect is formed of rings : it is, scientifically spealing, annulose. In the maggot or caterpillar stages, the rings or segments are sometimes horny, as in the Wireworm (Fig. 3), or soft, as with many linds of caterpillars (Fig. 1); and in the chrysalis state they are often only slightly observable.

* The absolute number of segments lias been a subject of much discussion; at one time they were considered to be typically thirteen; following on this it was considered that the three segments of the thorax were each typically composed of fuur lesser segments, and now it is given on good authority that tile head segment is composed also of four smaller ones. 
Next-Insects breathe by means of trachee. These. trachere are air-tubes communicating with the air by

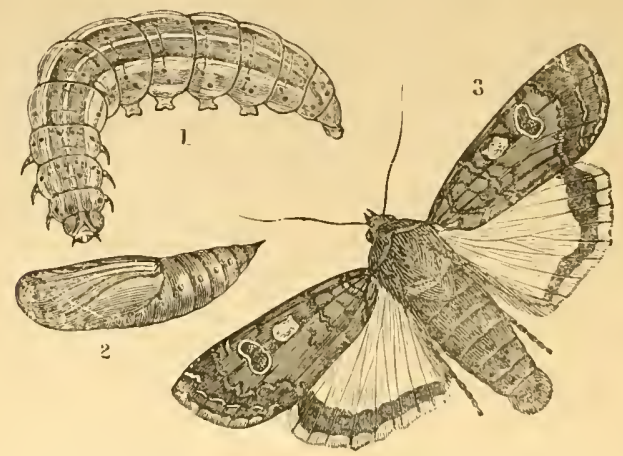

FIc. 4.-Yellow Underwing Moth : 1, caterpillar ; 2, chrysalis ; 3 , moth.

means of small openings or mouths of various shapes, called spiracles, * because through them respiration, or breatling, is carried on. They are generally placed at regular distances along the side of the insect. Fig. 4 shows the spiracles on the sides of the caterpillar and chrysalis of the Yellow Underwing Moth; but sometimes, especially in the case of Fly maggots, which live in putrid matter or wet places, the spiracles are at the end of the tail.

Of this the accompanying figure of the breathingtubes of the Warble Fly magrot (Fig. 5) is a good example. The tubes carry the air through the maggot, and the spiracles, when a little pressed out at the tip of the tail, are the little black spots so easily observable on maggots in warble-swellings on the backs of cattle.". Thus the magrot can live in the moisture that suits it, and yet draw in air by means of the exposed tip of the tail. Spiracles (or stigmata as they are sometimes called) are of very various shapes, from

* From spiro, I breathe. 
simple lips guarding the breathing opening, to the more compound form in which they may be found borne on short branched stalks placed on each side near the head of the larva, as is notably the case with rarious kinds of plant-stem-feeding fly maggots.

The various air-tubes (trachece) start from each spiracle, and then by means of branclies, which often join so as to form a net-work, they carry the air through every part of the insect, - limbs, body, and intestines. Insects do not draw in air through one mouth, as we do; neither have they lungs, but (commonly by means of the spiracles) the air-tubes bring

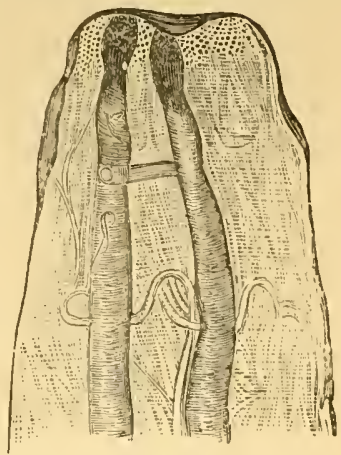

FIG. 5.-Breathing-tubes of maggot of Warble Fly, magnitied.

the action of the air to bear on the fluid answering to blood, which fills the hollow body of the insect. This fluid is not conveyed in veins, in the same manner as with us; but circulation is carried on by means of a long vessel, which may be compared to a long heart, lying down the middle of the back of the abdomen. This ressel is divided by constriction into successive chambers, and is furnished with slits at the sides. Through these slits the blood-fluid, which lies freely in the cavity around, enters the so-called heart, and by contraction or a kind of pulsation pushing it from the hinder part of the vessel, the blood is driven along it to a kind of aorta near the hearl. From this aorta it is stated to pour freely into the body eavity, and return in streams to the heart. Thus the main part of the circulation is carried on, whilst air is conveyed to the fluid by the passage of the breatling-tubes or trachere through the fluid.**

* The above short and general description of the main prineiple of the circulation is chiefly taken from Claus and Sedgwick's "Text. 
Some knowledge of the method of respiration as well as of circulation in insects is very requisite to agriculturists for practical purposes, for if the breathing-pores are choked the insect dies. The fact of the head of the insect being free is of no service, for the chief use of the head is for feeding or seeing with; but if the caterpillar or insect is so treated by being turned out. from its natural home, or by being covered with any sticky dressing that its breathing-pores are choked, it dies; and in this way we can act on some of our crop pests.

Metamorphoses or transformations of insects.-In the case of most animals, or at least of the higher orders of the animal creation, we find that there is commonly a marked difference in each instance, whether it be, say, a horse, or whether it be a ehicken, between its shape and external appearance, as well as its internal organs, in its early life, and in its mature state. But there is this noteworthy difference between this method of growth and that of insect life, that whereas with many animals the alteration goes on so gradually, from birth to mature life, that we do not see any sudden change; in the case of insects the change of appearance is often very rapid. The alteration itself goes on gradually, but from the moult of the skin (such as that of the caterpillar showing the chrysalis within it) frequently taking place in a very few minutes, the difference in appearance of the insect is often, to those not used to the matter, most astonishingly sudden, and gives rise to all hinds of unfounded ideas. These changes, which happen according to regular laws, are what are known as the "metamorpheses," or "transformations" of insects, because the insect is then, as it were, "metamorphosed" or "transformed" from one condition to another.

book of Koology,' Eng. trans., Ed. of 1889, p. 5:3:3; there is also much serviceable description of the ressels and mode of circulation in Newman's 'History of Insects,' 1'1). 1:8-1!)1. 
Insects pass their lives in three different conditions, after they have been hatched from the egg or produced alive by the parent. The first of these is that of the caterpillar, maggot or grub (or, to speak scientifically, the larra), in which the creature feeds voracionsly, often grows fast, and has no wings. The second is that of the chrysalis or pupa, in which the wings and complete internal organisation are forming. The third state is that of the perfect insect, or imago, with all its limbs and powers complete. This is the common course of insect-life through its transformations after being produced alive, or hatched from the egg; larva, pupa, perfect insect, or imago.

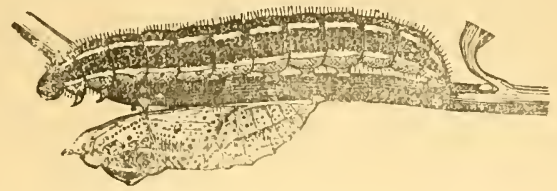

FIG. 6.-Caterpillar and chrysalis of Large Cabbage Butterfly.

It may be desirable here just to pause an instant to suggest that for many points of insect description, or of instruction in methods of insect life mainly needed for field use, where an English word has a well-known meaning, and may correctly and properly be used, it should be used.

In class or technical instruction the pupil must be made acquainted with the scientific terms customarily used; but he should at the same time (for the sake of being able to pass his knowledge on serviceably in farm life) be equally well informed as to the commonly adopted English terms. In scientific communication it is convenient, as well as correct, to describe the first stage of any insect as a larra; but there are many circumstances in which it would be quite as correct, and very much more intelligible, to deseribe a butterfly larva as a caterpillar, and a beetle larra or a fly larva as a grub or maggot. 
Larce is a Latin word, meaning a ghost or phantom, and was applied by Linnæus to the first stage of insect-life, from an idea of this being a kind of phantom-like shadowing-out of the real or complete state. It is a very fanciful idea; but the term larva luaving been adopted for the first stage of all insects, we cannot help ourselves about it.

Pupa is a Latin word, describing young animals not yet complete in their organisation; therefore it is very suitable to the state in which the complete insect is forming. This stage is also often known, especially in Butterflies and Moths, as the chrysalis state, from

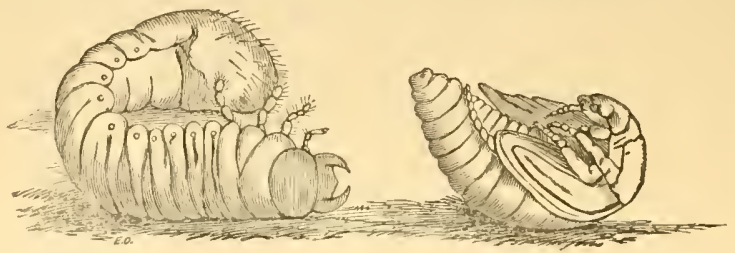

Fig. 7.-Maggot and pupa of Cockchafer.

a Greek word, signifying golden, some chrysalids being of a bright gold-colour.

Imago is the Latin for an image, or representation, and is used for any lind of insect in its complete state, - a Fly, or a Beetle, or a Grasshopper, for instance, is an imago.

Any insect in its first state is a Larra, any insect in its second state is a P'upa or Chrysalis, and any insect in its third state is an Imago. Thus the regular order of the progress of insect-life is-1st, larve hatcher from eggrs, or produced alive; 2ndly, pupe, in which state the larve change to their full powers; 3rdly, imagnes, that is, insects in their perfect state, in which they usually have wings.

If we now trace these changes forward from the beginuing, we shall be able to prove them for ourselves, as a matter of living serviceable fact, which may be given as solid instruction where needed, and 
also as practical information, fit for a reasonable man to receive, to the many who depend on the food-crops for their livelihood, and who will thankfully accept all reliable aid that may tend to lessen their yearly losses through insect attack.

In order to trace the progress of insect life onward from its very commencement, with the certainty that the eggs which we may wish to observe have been deposited by any special insect, we may take the females, when about to lay, and secure them under a glass, and thus we can study the characteristics of the eggs laid by different linds of insects.
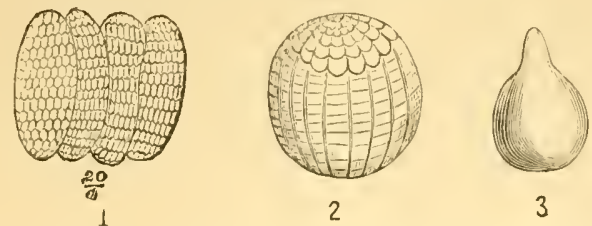

Fig. 8.-1, Eggs of Beet-fly ; $2 \& 3$, eggs of Butterflies, magnified.

Insect eggs are of various shapes: they may be round, or oval; conical, or pear-shaped; or of other forms; sometimes, as seen under a magnifying-glass, they are beautifully marked with stripes, net-work, or other patterns; and they also differ in the nature of the outer coat, which sometimes is hard and crisp, sometimes a mere flexible film. These eggs are, for the most part, laid by the parent insect on, in, or near the substance, be it plant or animal, which is to be the food of the "maggot" or" other lind of larva which will presently hatch from them. Sometimes the eggs are laid in places from whence they will be carried to a suitable feeding place for the grubs that hatch from them. The Horse Bot-fly, for instance, lays her eggs on the horse, and by means of that animal (or another) licking them off they are carried to the mouth and thence pass down to the stomach. Some linds of insects, by means of apparatus forming 
a sharp point, insert their eggs in caterpillars, or other living structures on which the grubs from the eggs feed; some lay them with a long gummy thread attached on which the eggs stand up like pin-heads on their stem. In fact, the forms of eggs and methods of deposit are endless; but such a large number are noticeably laid on decaying animal and vegetable substances as to have given rise to the popular idea that insects are "bred," as it is phrased, by rotten matter and putrid water.

It should be clearly borne in mind, and instruction carefully given, that this is never the case. Insects are only produced from insects; they are never engendered spontaneously, nor by putrid matter of any kind. They are often to be seen coming out of such filth, or the grubs and maggots are to be found swarming in it; but if watch is kept it may be seen how attack is started by noticing Gnats laying their masses of eggs ("egg-boats," as they are termed) on stagnant water; Blowflies laying their eggs, or eren their hatching maggots, on meat, bones, or carcases; Beetles laying their eggs in dead animals or cattledroppings, or in decayed wood; and with a little watching the grubs will be found hatching according to the nature of their parents.

This is an important matter to understand rightly, for it sometimes happens that there is an uneasiness as to whether varions linds of crop attack are set on foot by insects brought with manure; and although we are very safe from bones or dung "breeding" maggots, yet nothing is more likely than that various kinds of insects (for instance, cabbage and turnip-root flies) will be attracted by farm manure to lay their eggs in it or near it, and that the maggots will thence go on to the roots.

Sometimes instead of being deprosited as an egg the young insect is produced alive. 'This is often the case with the young of Aphides or Plant-lice, and also with some kinds of two-winged lilies. 
The growth of a grub before hatching may be watched by taking an egg, partly advanced towards maturity, and laying it on the stage of a microscope. If you get a transparent one, such as that of the Turnip-blossom Beetle (Meligethes (eneus), you will be able to see the grub within growing, day by day, until it gradually bursts the thin skin of the egg, and walks out of it as a complete grub, witl clawfeet, head, and jaws. Thus the history may be shown so far: we may find eggs within the female, see them laid, see the larva grow within them, and
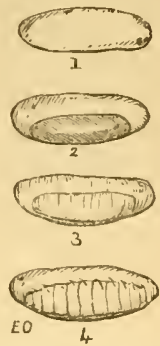

FIG. 9.-Eggs (mag.) of Turnipsee it step out of them, often, if not always, ready to attack its appointed food, whether vegetable or animal, -in some cases a live specimen of its own kind.

Larre-that is to say, insects in their first stagesmay be divided into two kinds. One kind, such as Locusts, Crickets, Earwigs, Aphides, and some others, are very like the perfect insect, to which they will presently change, in all respects, excepting being smaller, in gradually increasing in size,

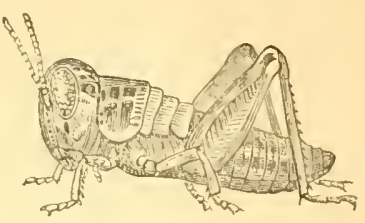

Frg. 10. - Larra of Locust. and in being wingless. The other kind, which we know as maggots, grubs, or caterpillars, are quite unlike the Beetles, or Wasps, or Flies, or Moths, or other insects, to which they will change in due time. The general appearance of these dissimilar larvæ is well-knowin, and many figures of them will be found in the following pages.

They may be said to be usually long, narrow, soft, and cylindrical ; the rings, or sucessive segments of which they are formed, often show very plainly; the 
liead, which is often horny (or, in some maggots, in a soft retractile mass), is furnished with jaws or hooks, or some means of gathering up food, and sometimes with eyes and horns; and according to their kind they are either legless, or have a pair of short jointed legs on each of the segments behind the head, or in addition a pair of sucker-feet, suited for holding by, at the end of the tail, and from one to seven pairs of suckerfeet beneath the body. By some one or other of these
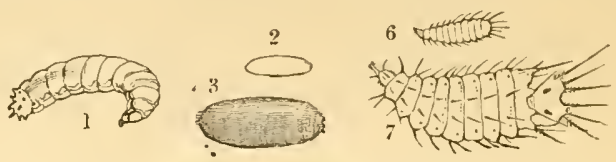

Frg. 11.-1, 6 and 7 ; larve ; 2 and 3 , pupæ of Flies, nat. size and magnified.

points they may be easily lnown from earth-worms, centipedes, milleperdes, wood-lice, and the other small creatures that infest the same lind of places.

Insect larve feed on almost every kind of animal and regetable substance, fresh or putrid, and also in stagnant water; but wherever they live, or lowever thcy may differ in appearance, they seem all to be alilie in being most roracious in their appetites. They eat and grow, until the skin not being able to stretch further they pause in feerling for a while; the outer shin beconnes loose, and is thrown off, or moulted, as it is termed. In the case of Grasshoppers, or insects nearly alike in the larval and in the perfect state, this change is a wonderful process, for the young insect has to free itself of the outer coat of its long slender limbs, and of all its onter surface, as completely as the thick fleshy grub or caterpillar, which sometimes, by taking firm hold with the pair of sucker-feet at the end of the tail, can drag itself much more easily out of its cast clothing. When the moult is completed the larva eats again. 'This progress goes on, according to weather and other circumstances, until the larra 
have reached their full growth; this may be in a few weeks or months, or it may not be for three, four, or even five years. Then an internal change takes place, and the young insect leaves off feeding; and then in the case of the "similarly changing" insects, such as Grasshoppers, Plant-bugs, and some others,

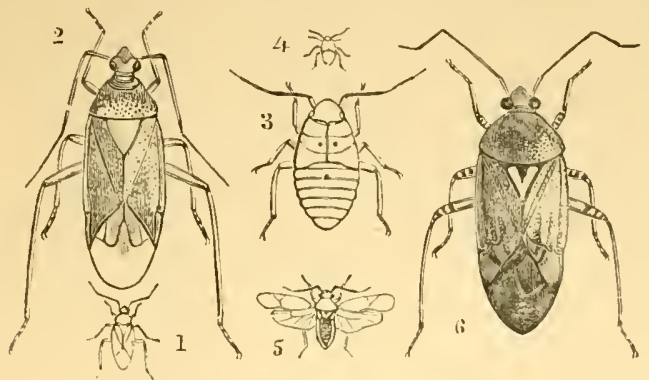

Fig. 12.-1 and 2, Potato-bug ; 3 and 4, pupre of ditto, nat. size and magnified; 5 and 6 , Hop-bug, nat. size and magnified.

the larva, for the last time in its larval life, draws itself, limb by limb, out of its dead skin, and stands as a pupa. The skin having been shed, we see that it has now made its adrance to the second stage, showing some advance towards wings and wingcases, in such kinds of insects as have them when perfect.

In the case of the varions larre, such as maggots, grubs, and caterpillars, which are "dissimilarly changing " insects, that is, in which the first stage is quite different from the two that follow, the larra, when it is going to turn to the pupa or chrysalis, commonly seeks some place, or makes use of some natural shelter, where it can lie securely during the time which it must pass inactive and defenceless whilst it is going through the pupal state, and there it casts its larval coat for the last time, and appears from within as a pupa or chrysalis.

The various changes or metemorphoses described 
above are not mere matters of curious enquiry, but can be used rery serviceably.

Insects, if circumstances permit, lay their eggs where the larva which come out from them will be able to feed at once; therefore we may prevent a great deal of coming attack by clearing away the large amount of weeds which many kinds of insect

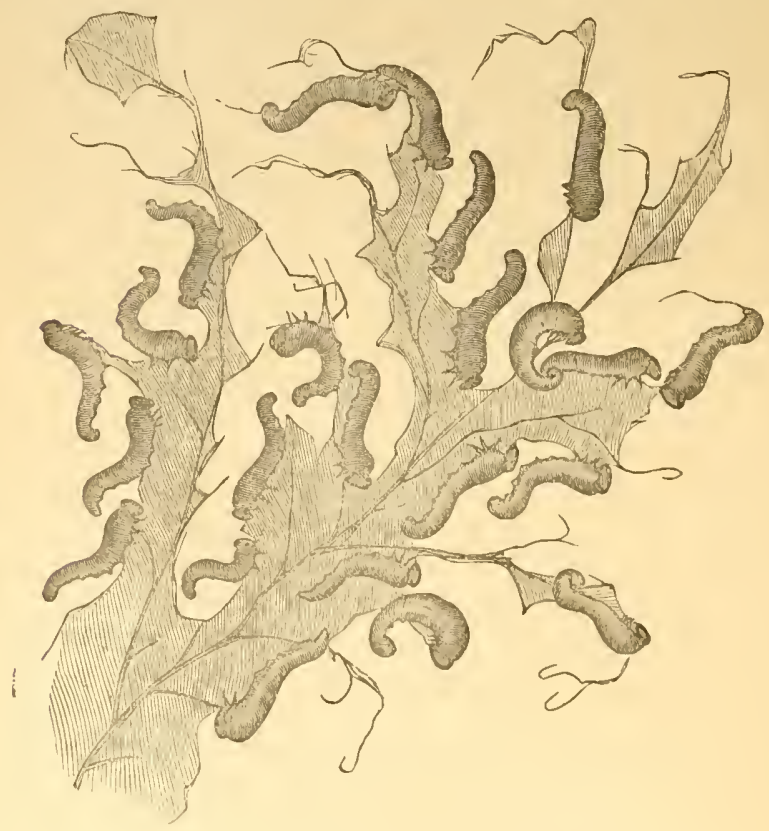

Fic. 13.-Sawfly caterpillars destroying Turnip-leaf.

larva feed on as well as the cultivated crops; and thus we greatly lessen attraction for the insects to the neighbourhood. On the same principle pasture land is dressed, or sheep folded, to lieep off egg-laying; or ground is drained where special pests prefer wet land. 
Again; the caterpillar, or grub, feeds voraciously ; and if there is nothing for it to feed on it soon dies. This is another reason for thorough cleaning of arable land. Many of the common weeds, such as Charlock, Couch-grass, and also some of the marsh-weeds, keep various of our pests alive and thriving, especially in spring, till there is crop-food for them; therefore, if we bear in mind that if these voracious appetites are not supplied the grubs die, we shall remember better to have the fields cleaned.

The point of the caterpillar changing its coat from time to time is sometimes most serviceably worked forward, as in the case of the Turnip Sawfly, which cannot quit its skin unless it is firmly fixed by the tail of the old one; if it camnot drag itself out, it perishes in the stifling wrapping of its late coat. This lnowledge is utilised by brushing; or driving sheep through the attacked fields; and thus by simply loosening the hold of a destructive pest we save much of the crop.

Caterpillars can bear a great amount of cold without any injury, so long as they remain where they have placed themselves for the winter. Some will bear being frozen hard without the least injury; but if they are disturbed from their cells under the surface of the ground, and left exposed to freezing in wet loose soil, they perish.

Probably in this many circumstances act together, -the choling of the breathing-pores for one thing, the drying up when exposed to wind for another, and also the starvation of the creature if it wakes up from its sleep in such circumstances. But however this may be, if we know the habit of some catcrpillars to be helpless and torpid during winter, we can readily act on it.

But though some kinds of larve will bear great cold, yet the size, the colour, and the date of the appearance, and also the presence or total absence of some kinds of insects, have been found to depend greatly on difference in weather influence, and amongst other 
things, as in the case of the well-known Colorado Beetle (Fig. 14), on amount of cold and on height above sea-level. Also in the fact of the hordes of insects, which fairly sweep all before them on the great continents, being suited for the climates where they are found, but not for the constant change of our island weather, we have a good reason for not fearing. their attack.
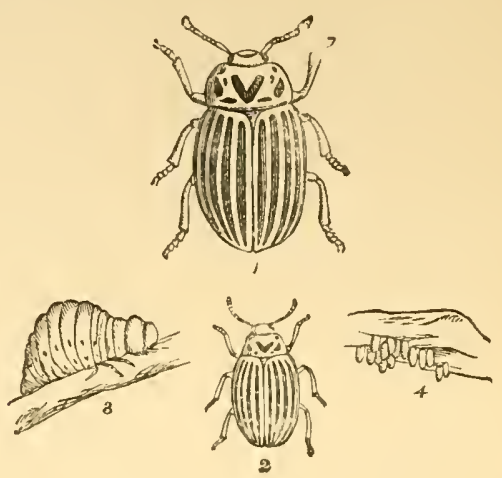

Fí. 14.-1 and 2, Colorado Beetle, magnified and natural size; 3 , caterpillar ; 4 , eggs.

The shelters which caterpillars and grubs of various: kinds make for themselves to turn to the chrysalis in, or to secure themselves in during winter, are of many kinds. Some caterpillars, like those of the Silkworm, have then the power of secreting a gummy fluid, and by means of drawing this from their mouths they can spin silken cocoons, within which they slip, or rather shuffle, off their old caterpillar-skin, and turn to chrysalids; others (as some of the common White Cabbage caterpillars) liang themselves up by a strong spun thread passed round them, which acts as a band to keep them from falling; and many of the crop-feeding kinds simply hollow a cell in the ground, in which they lie protected from moisture and sudden changes of temperature; many Fly maggots contract, and as. 
the outer skin gradually hardens it forms a safe case for the fly forming, in its pupa state, within. But whether as a Beetle grub, or a Fly maggot, or a Moth caterpillar, they, as a rule, seek or make use of some kind of shelter ; and if we know what and where this is, we can do much to lessen the great numbers of crop insects which otherwise are sure to collect where their food is to be found.

\section{CHA P TE R II.}

CHRISALIS-PERFECT INSECT-ORDERS.

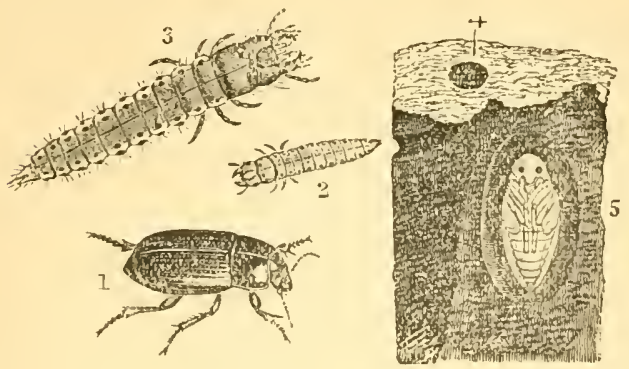

FiG, 15.-1, Corn Ground Beetle; 2 and 3, grub, nat. size and magnified; 4, burrow of grub; 5 , chrysalis.

In the preceding Chapter some amount of general description is given of the early conditions of insect life up to the stage when the maggot, or grub, or caterpillar (or larva, to use the term which includes the first stage of life of all insects), having completed this first feeding period of its life, throws off its skin once 
more, and appears as a pupa or chrysalis; also how in many instances, and especially those of insects which lie inactive and defenceless whilst in the chrysalis shape, the grub spins a web cocoon, or hollows out a cell in timber or in the ground, or in some way avails itself of some lind of shelter for the coming need of it. Here the change, which was beginning when the larva took slrelter, is gradually completed.

The accompanying figures show the change that takes place in the case of the Corn Ground Beetle, and also in the Heart and Dart Cabbage and Turnip Moth. The form of the creature, which was contained in the

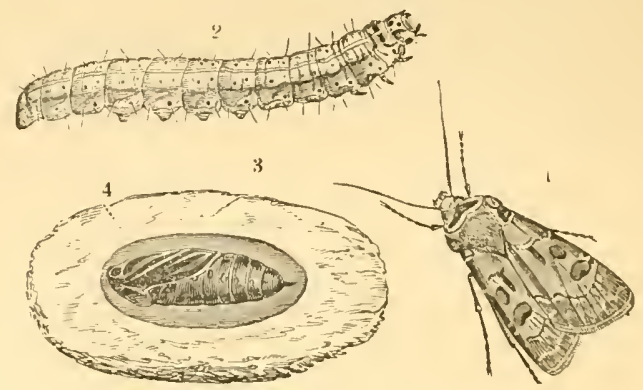

Fig. 16.-1, Heart and Dart Moth ; 2, caterpillar ; 3 and 4 , chrysalis in carth-cell.

caterpillar or grub or maggot-skin, alters; the legs, the wings, the mouth apparatus, and all the other parts which the insect will possess in its perfect state, develop, until within the old dead eaterpillar-slin, or within the contracted skin of some kinds of Fly magunts, there lies a distinctly differently shaped creature. The clange is gratual; but the operation by which the chrysilis casts off its useless coat, and appears in its changed state, is often the work of a very few minutes. This may easily be seen with some butterfly caterpillars, and especially with the spiny black-andwhite-spotted caterpillars of the Peacock Butterfly, which maty often be found in large numbers ou Nottles. 
When these are ready to change they will fasten themselves up, by the pair of sucker-feet at the tip of the tail, to web spun on anything convenient. There they hang head downwards ; and after much wriggling and twisting the black slin splits, and is gradually rolled, by the muscular struggles of the chrysalis within it, up to the tail, the briglit shiny green of the chrysalis allowing the exact progress of operations to be very clearly seen. In a short time the old skin is completely rolled up to the end of the tail, and the green moist chrysalis hangs as a defenceless body, but yet showing the shape of the legs, and wings, and mouth parts of the coming butterfly, where the black slin of the caterpillar, with its six claw-feet, hung a few minutes before. A kind of gummy secretion which is given out hardens over the surface, and preserves the insect forming within from injury.

To enable the student to see clearly, and ascertain for himself, how far development has adranced at this stage, it is a good plan to take one of the chrysalids, before the wet gum or cement on it has hardened, and drop it into anything that will melt the forming cement away (I have used a mixture of warm turpentine and Canada balsam in a phial, as this keeps the specimen expanded afterwards).

It will then be seen that the partially-formed limbs of the butterfly are all there: the three pairs of legs, the still mexpanded wings, and the trunk or prohoscis, which would have suclied honey from many a flower. It is well worth while to watch the process of change, and prepare a few specimens as abore, for thus

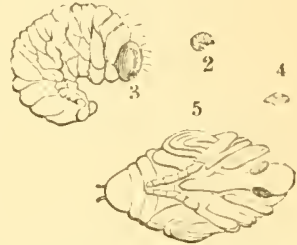

Fig. 17.-Larva and pupa of Clover Weevil, nat. size and marnified.

we can convince ourselves, and those we may have to speak to on the subject, as to what is the exact course and nature of one kind of transformation. The gummy covering gradually liardens, and within this 
the Butterfly or Moth forms and matures till its time for active life is come. Then it cracks the thin coat and steps out, the moist wings soon spread, and in a short time the insect occupies five or six times the space it did before, and is perfect.

The Beetle grub throws off its old skin, and lies as a pupa (or chrysalis) in galleries in the timber where the grub fed, or in the ground, or wherever its instinct may have taken it, inactive, but in appearance much like the Beetle, to which it will presently turn. Only till complete in all powers, it lies with its limbs, usually in separate sheaths, beneath it. (See Fig. 17, preceding page.)

The maggot of the Wasp, the Sawfly, the Gallfly, and others of the Wasp order, also change (as we may

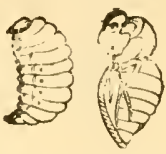

F'ig. 18.-Larva and pupa of Marble-gall FIy. see in a piece of TVasp-comb) by turning to pupre, in shape like the perfect insect; often in the comb-cell where the maggot fed; often in a cocoon in the ground, as with some Sawflies and Ants; or in the Gall, which served the grub at once for food and shelter, as with many of the Oak and other Gall Flies.

'l'he Dipterous maggot, that is the maggot of the two-winged Fly, usually, or at least often, changes to the pupa state within the oval case formed by its own hardened and contracted slin. Sometimes the change takes place in an outer film, showing the shape of the limlss within. See references, in list of Figures, to Tipula and 'Trichucera.

These different methods of change show the kind of transformations which the dissimilarly changing insects go through; that is, the insects which we know as grubs, maggots, or caterpillars, in their first stages. They leave off eating; many of the caterpillars leare the place where they were feeding, and being no longer observable on the plants, and the. 
plants themselves not showing further marks of ravage, it is often thought that the mischief is over; whereas the trouble may very likely have only ceased for a while, to arise again when a new brood of insects comes forth from the chrysalis or pupal state.
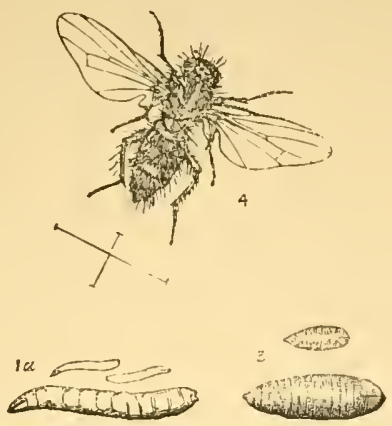

FIG. 19.-Wheat-bulb Fly, mag.; larvæ and pupæ, nat. size and mag.

It is also to be observed that many of the brightly colomed caterpillars, such as those of the Death's-head Moth, alter in colour to a livid dirty tint when they are about to cease feeding; and thus the protection, which is often given by similarity in general tone of colouring of the grub to the coloning of its food, may be changed to the protection of the more earth-like tints when they are about to bury themselres.

In the case of the Grasshoppers, Aphides, or other insects, known as the "similarly changing," which differ little in appearance and little in habits throughout the three stages of their lives, the change is not so marked. When the insect moults its old skin it lias to draw itself carefully out of its neatly fitting coat, and the operation may be observed in dutail if a fair sized insect, such as a Grasshopper, is cauglit just when it is about to moult. When I have watched it myself the operation took twenty minutes. The back of the insect, or rather of its old skin, cracked, and through the opening there came out, very slowly and carefnlly, the insect from within. Each portion 
was drawn out in orderly succession, until everything, holns included, was free, excepting the long leaping legs, the hindermost of the three pairs. These were left till the last, and seemed to need the utmost care and management to get them safely out of their tightly fitting covering; but they came out all right, and the real insect and its cast skin stood, as counterparts in. almost all respects, side hy sirle.

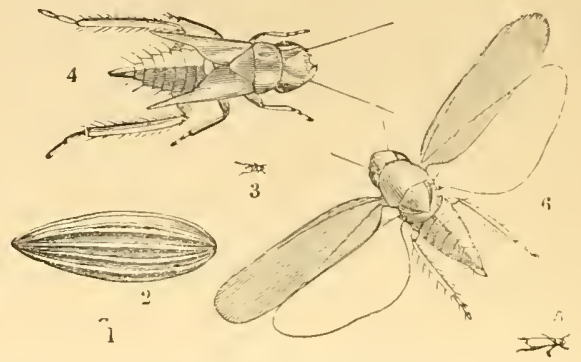

Frg. 20.-1 and 2, eggs; 3 and 4, pupe; 5 and 6, Potato Frog Fly: nat. size and magnitied.

No general rule can, however, be laid down as to distinguishing the stage of life of the "similarly changing " insects by absence of wings or wing-cases. Aplides or Plant-lice have both winged and wingless females; in some of the Cochroaches the wings are absent in the females; so are they also in both males and females of one genus of Earwigs.** Fig. 20 shows a pupa, resembling the perfect insect, except in the absence of dereloped wings and wing-cases.

Without investigation as to internal condition $\mathrm{ol}^{\circ}$ development, the precise stage of advance of the insect cannot be theoretically laid down, but without entering lere on points of internal organization (and excepting Aplides, of which the development is a most intricate study), the condition may be lnown, in a general way, as being that of lare whilst they are quite wingless, 
that of pupe when the wing-cases and forming wings show more or less, and that of perfect insects or imagos when (with all kinds that have powers of flight) they have their wings complete.**

When the insect has come out from the chrysalis or pupa, it is perfect; it will grow no more, excepting from its wings expanding in some kinds (as with Moths and Butterflies) in which they were not fully spread, or were folded tightly in the chrysalis case. The internal organs are now also perfect, and its remaining work is to propagate its species.

Many kinds, which have been ruining our crops for months as voracious grubs, are now harmless during the short remainder of their lives; but some, on the contrary, of our worst crop-pests, such as the Turnip and Mustard Beetle, live through the winter, and in their perfect state ravage as badly as or worse than they did in their first stages. These points, or points such as these, regarding the condition of insects at different times in the year, and their general habits, are what we need to know about much more than their structure, and this knowledge is to be gained in part by careful personal observation, in "part by study of sound recorded information. Therefore, before going on to field observations, it will be serviceable, firstly, to take notice of some points of structure whish all perfect insects possess in common; and afterwards to see how, by some few and very clear differences (when noticed together with the different transformations of which we have just been speaking), we may tell what order an insect belongs to, and thus advance to a general idea of its method of life. I trust to be able to show that by mastering a few simple details we may gain all the knowledge we want, as a foundation, either for field use or to carry on further study of insect life scientifically, if we wish.

* Some of the special exceptions are mentioned under the details of the different orders. 
A perfect insect has a head and body; the body is divided into the fore and the hinder body. When the insect has its full number of limbs the fore body (or thor $a x$ ) bears, or is borne, by three pairs of legs and two pairs of wings ; the hinder body (abdomen) contains a large part of the intestines and other organs of digestion, and those of reproduction. The head is distinct from the body, and has a pair of horns (antennce); and (for the most part) eyes. These are compound and simple eyes. The compound eyes are formed of a large number of lenses or facets, forming together an immov-

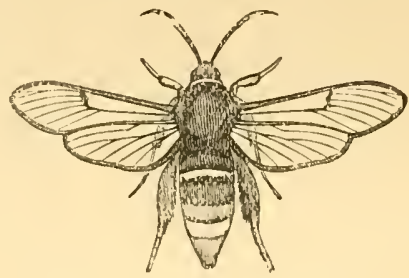

Fig. 21.-Hornet Clear-wing.

able mass, sometimes occupying nearly the whole of each side of the head. The simple eyes are each a single lens. These are little specks placed on the crown of the liead, or thereabouts, and are very few in number; I am not aware that there are erer more than three, and some insects are without them. The mouth and feeding apparatus, though it looks so different in different insects, is considered to be made up of the same six parts in all. These are an upper and an under lip, and two pairs of jaws, which in the biting insects work from side to side (laterally, not vertically) between the lips. The upper pair of jaws (mandibles) is often strong and lorny; the lower pair, or "feeler" jaws (muxillce), takes its name from laving feelers (palpi), as has also the lower lip. 'These parts of the mouth vary rery much in shape, as we may see in the trunk of a Moth, or the proboscis of a Fly; but 
still these differences are considered to be in every case only varieties in the general form just noticed. Every one of these parts has a scientific name; and thronghout the insect there is probably not a point which can be observed by powerful magnifying-glasses which has not a special distinctive name; but for the purposes at present under consideration we do not need to go into these minute points.

If we have to write or speak to naturalists of other countries, or if we speak of minute divisions, only seen by scientific means, then we need special scientific words. But for the matters of field work, which we speak of daily, and see with our own unassisted eyes, it is much the best way to use words which will be understood at once by all around us. This may generally be managed, with regard to the insect, by taking the word which would be used for the same part in other animals; and this course has been in part adopted by our best entomologists. If we speak of the horns, or (with regard to the legs) of the thigh, shank, and foot, everyone will know what we mean; and the only real difficulty in our branch of the work is to provide a counterpart in English, for the word thorax. This is the fore part of the body, and the word trunk was formerly used for it; now, however, this word is used for a portion of the mouth: but we may speak of parts of the thorax as shoulders and breast; and possibly, where thorax would not be understood, the term "fore-body" might serve.

For practical use all that we need to have is just such a lind of linowledge of the crop insects as we have of the erops; for this (that is for field purposes) it is enough for each grower to know, by the lind of injury to the crop, taken together with the appearance of the insect injuring it, what it is that is at work, and thus be able to tell, or ask for, the method of prevention of its ravages; or, if he prefers, by having a book at hand, and simply looking out the crop in the index, and then turning to Peas, or Beet, or whatever it may 
be, he will most likely, if it is any kind of attack commonly injurious to a serions extent, see a figure, history, and account of the best known means of prevention or remedy.

But in our present study we are aiming at something more. We wish to gain enough information to be able to tell which of the large divisions (orders, that is) of insects whatever insect we may be observing belongs to, because thus at once we shall know many of the chief points of its history. We shall know what changes it will pass through, which is a very useful piece of information; and if once we have the chief points of distinction of the orders firmly fixed, we have a true foundation, on which we may build up any further knowledge. This is not by any means a difficult matter.

Insects are divided into Orders, which are named according to the nature or number of their wings. This difference in the wings occurs so regularly, along with difference in the nature of their changes before they advanced to the perfect or imago state, that thus their general life-history before they got their wings may be fairly known. A common two-winged Fly had, generally speaking, a legless grub, and so on.

These orders are usually so divided as to be thirteen in number, and the scientific names of these all end in the word ptera, wings, from the Greek word pteron, a wing. The previous part of the name of each order describes the number or the form or the nature of the wings. These orders are placed in two divisions (as given below) according to whether the insects of which they are composed feed for the most part by means of jaws working horizontally or laterally, that is, from side to side like pincers lield flat; or by means of a trunk or sucker, or piercing apparatus. 
Orders of Insects.

WITH JAWS.

Coleoptera. Neuroptera.

Euplexoptera. Trichoptera.

Orthoptera. Hymenoptera.

Thysanoptera. Strepsiptera.
WITH SUCIERS.

Lepidoptera.

Homoptera.

Heteroptera.

Aphaniptera.

Diptera.

For working purposes, however, in connection with crop insect pests, it will be much more convenient, instead of studying the orders in the succession noted above, to take, firstly, those orders which are maggots, or caterpillars, in their first state, and arrange them, in succession, by the increase in the number of legs or sucker-feet of the grubs, and wings, or apparent wings, in each order; secondly, the orders wlich are nearly alike in all their states, as Grasshoppers and others; and, thirdly, just to give a few words respecting the orders which, for agricultural purposes, require some little further attention.

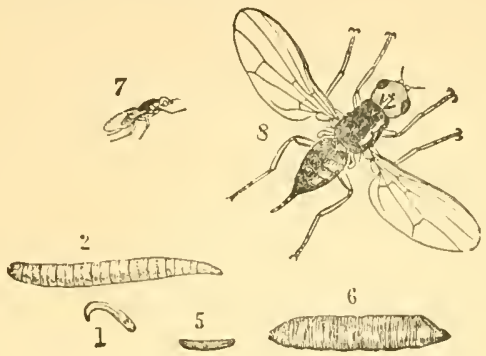

Fig. 22.-Carrot Fly: 1 and 2 , maggot; 5 and 6 , pupa. All nat. size and magnified.

Firstly, then, we take the five following orders:1, Flies; 2, Fleas ; 3, Beetles ; 4, Moths and Butterflies; and 5, the order which includes Wasps, Ants, Sawflies, Ichmeumon Flies, and many other Wasplike Flies. 
Fuies (Diptera) - two-winged-have only two wings, and a pair of poisers instead of the hinder pair. These appendages are often pin-like in shape. Maggots legless. (See Fig. 22.)

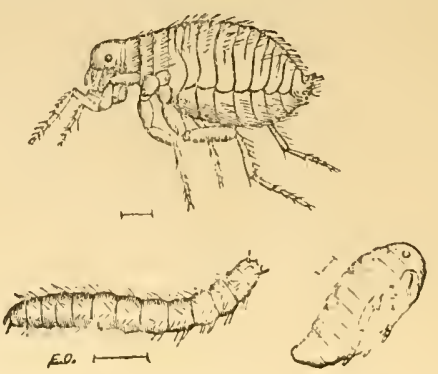

FIG. 23.-Flea, maggot, and pupa; magnitied. (Aphaniptera.)

Fleas (Aphaniptera)-imperceptible-winged-liave no real wings, but with a good magnifying-glass they will be seen to have two pairs of scales, which have been considered to represent two pairs of wings. The grubs are legless.

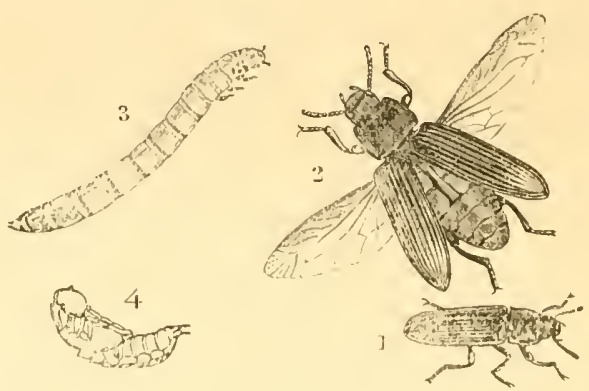

F1. 24.-Mealworm Beetle, nat. size and magnified; grub_and pupa (Coleoptera.)

Bentles (Colcopteru)-sheatl-winged-have two pairs of wings, the upper pair horny, and thus forming a kind of "slieath" for the under wings. 
Grubs sometimes legless,* sometimes with three pairs of feet, and a sucker-foot at the tip of the tail.

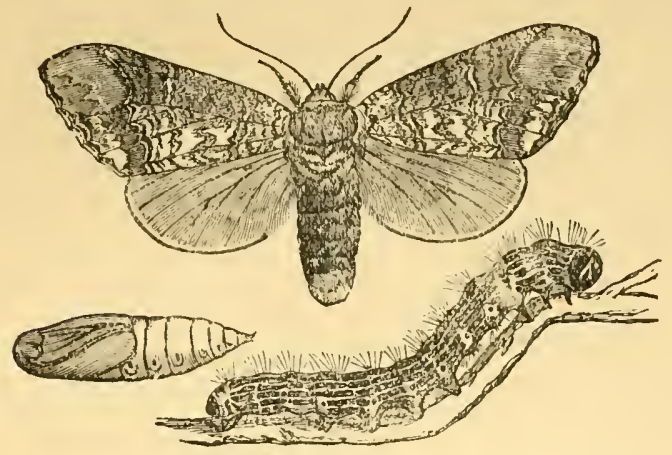

Fra. 25.-Buff-tip Moth : eaterpillar and chrysalis. (Lepidoptera.)

Moths and Butterfuirs (Lepidoptera) - scalewinged-have customarily four wings, covered with powdery dust, which is formed of differently shaped

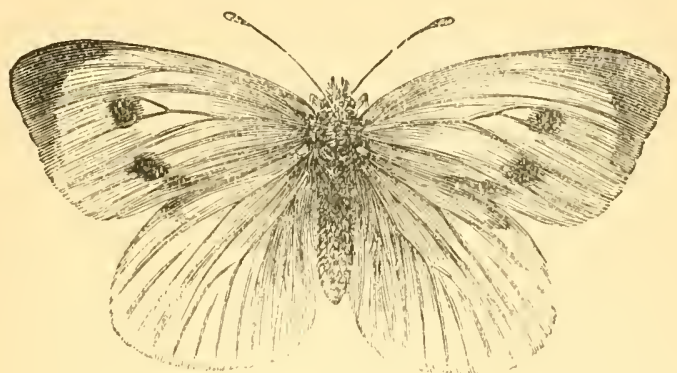

Fig. 26.-Large Cabbage Buttertiy. (Lepidoptera.)

scales. The caterpillars have commonly three pairs of claw-feet, and a sucker-foot at the end of the tail, Index.

* For figures of legless Beetle grubs, see referenees to Weevils in 
and also from one to four pairs of sucker-feet under the body.

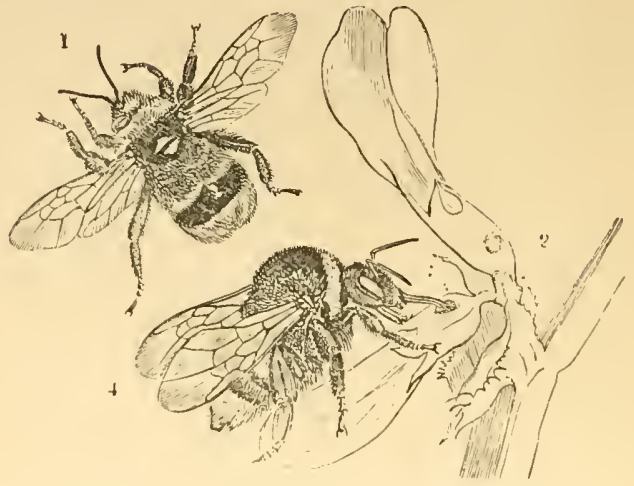

Fig. 27.-Humble Bees. (Hymenoptera.)

Bees, Wasps, Sawflies, Gallflies, IchneumonFuIEs, and others (Hymenoptera)-membrane-winged - have four transparent or thin wings, as if they were

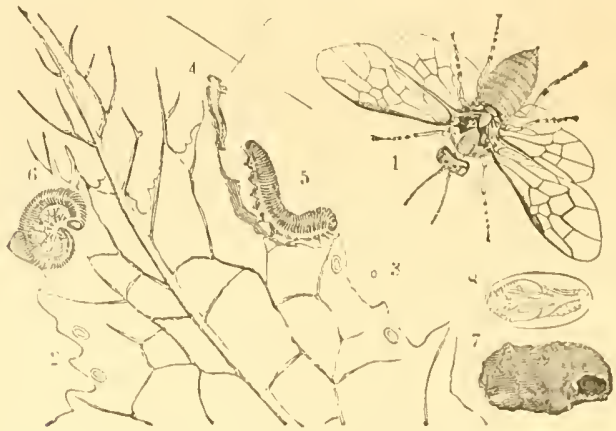

FIg. 2\$.-Turnip Sawlly, magnfied ; caterpillars, pupa, and pupacase. (Ilymenoplera.)

formed of a piece of membrane. The grubs are sometimes legless; but those of the Sawtlies, which are the grubs most injurious to plants in this order, have 
usually, besides the three pairs of claw-feet, five to seven pairs of sucker-feet under the body, and a pair at the end of the tail.

The above figures, and short notes, give just the primary distinctions between five orders of insects, in each of which the insect is completely different in its two first stages, that is, in its larval and pupal condition, to what it is in the imago or perfectly developed state. Further characteristics, especially those which are of use practically, are mentioned under the leads of the different orders; but even elementary knowledge, such as the above, is of service as a guide to the nature of crop attack which may be under observation.

Of the eight remaining orders, there are five in which the insects are nearly alike throughout their lives, and also in many cases troublesome to us: these are the orders containing, 1, the Grasshoppens, Locusts and others; 2 , the Earwigs ; 3 , the Aphides and others ; 4, the Plantr-iugs ; and 5, the Thrips.

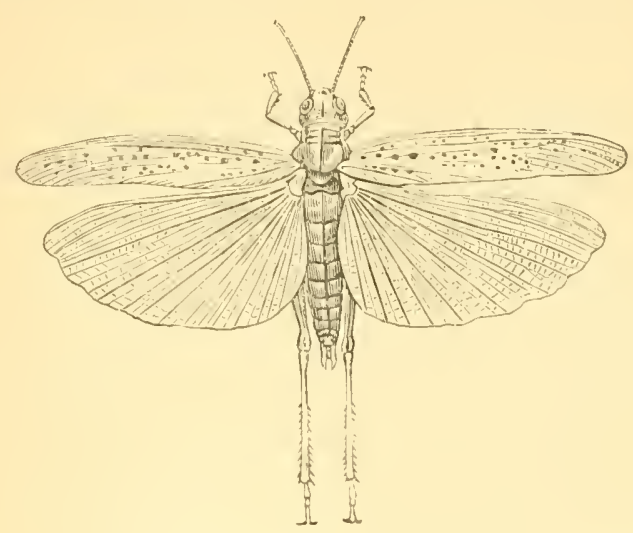

FIC. 2\%-Locust. (Orthoptera.)

Locusts (Orthoptera)-straight-winged-have the under wings folded lengthwise, or straight beneath the upper pair. 
EARwigs (Éuplexoptera) - tightly-folded wingedhave the under wings so very large, compared to the

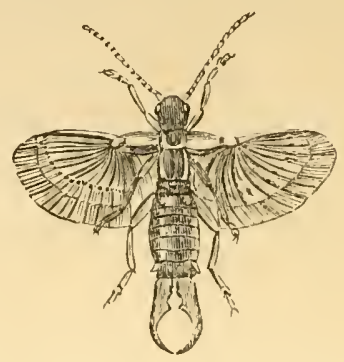

FIG. 30.-Earwig, with wings spread, magnified. (Euplexoptera.)

small upper pair (or wing-case), that they need to be very tightly folded to fit beneath them.

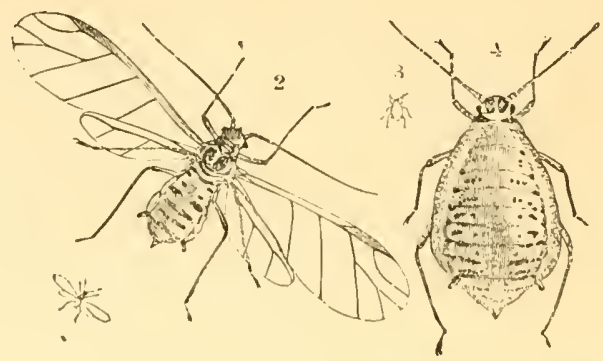

Fig. 31.-Cabbage Aphis: male and wingless female, nat. size and magnified. (IIomoptera.)

"Cuchoo-spits," Aphides, Scale, \&c. (Homoptera) - similar-winged-have the wings of the same nature throughout each, or both, of the two pairs of wings, in which they differ from the next order.

PL.1NT-Bugs (IIeteroptera, see Fig. 32)-dissimilarwinged-have a part of the upper wing that is nearest 
to the body dissimilar to the rest of the wing, which is membranous, as is also the lower wing.

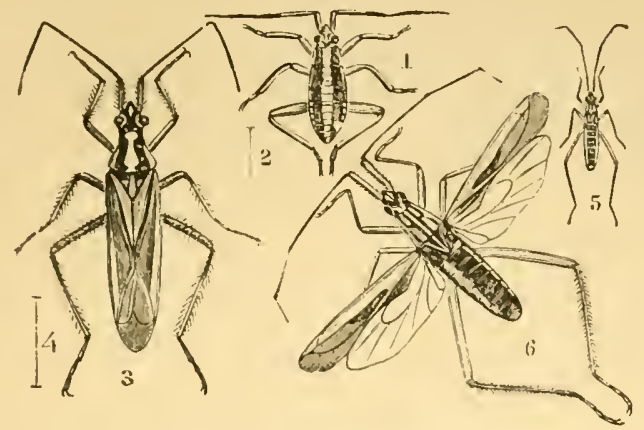

Fig. 32.-Wheat and Grass Bugs and pupa, magnified and nat. size. (Heteroptera.)

THrips (Thysanoptera) - fringe-winged - are very small insects, with four narrow wings with fringes round the edges.

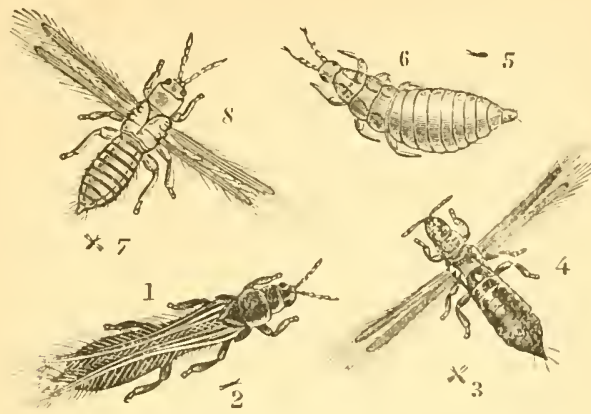

Fig. 33 - Thrips and wingless larva, nat. size and magnified. (Thysanopteru.)

The three remaining orders are those of Dragon Fuies (Neuroptera), CAddis Flies ('Trichoptera), and 
Bee Parasites (Strepsiptera), and need not be entered on; but I add a figure of Caddis Fly to show the

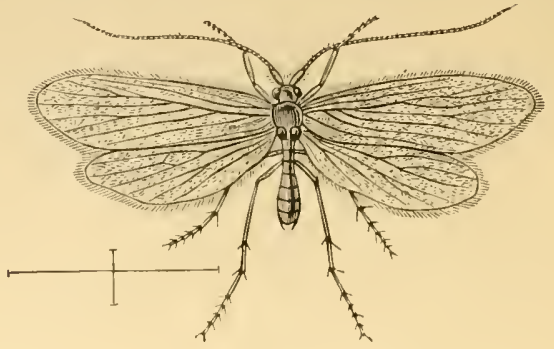

FIG. 34.-Caddis Fly, magnified. (Trichoptera.

general appearance, and also one of the Bee Parasites to show the peculiarity of the fore pair of wings, being

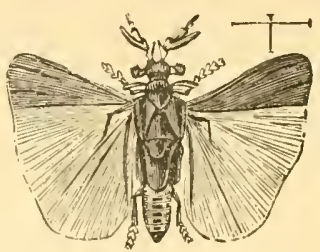

FIG. 35.-Bee Parasite, magnified. (Strepsiptera.)

only represented by a twisted growtll. The Dragon Flies also do not need illustration; but the figure

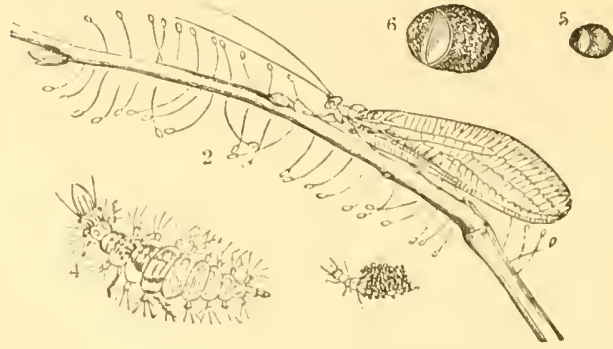

Fig. 36.-Golden Eye and stalked egres, larva and coco on, nat. size and magnificd. (Neuroptera.) 
shows a small four-winged Fly of this order, which lays each egg accompanied by a small quantity of sticky matter. This, drawing out into a fine thread with the egg at the extremity, gives it the appearance of being stalked, as shown in the figure.

In the following pages the order's of insects which most affect the welfare of the agriculturist are entered on successively, with descriptions of the most important characteristic distinctions of the divisions of these orders both in appearance and habits; also life-histories of some of our worst insect attacks, with means of prevention and remedy; and obserrations as to how knowledge of the history of the pest gives us at the same time knowledge of how it lies best under our power.

Information of this kind is useful to all who have to do with growing farm crops, or fruit or forest trees ; and year by year, as more and more land is taken into cultivation (as we are especially seeing now in the case of the fruit growing industries), we may expect to find that the feeders will multiply where the food is constantly grown on one spot, and that increased knowledge of how to counteract the increasing evil will be needed.

I would by no means adrocate, excepting for those who intend to make Entomology a special study, that they should spend their time in tedions research into matter's of structure and classification and the like, tending to no practical result, and requiring to be conveyed in words almost useless for common field service. But the knowledge of the life-history and habits of the pests (always more or less reducing the amount of crops throughout the country) is a plain matter, which with a little help may be easily acquired to a very serviceable extent. We may learn what agricultural influences we can bring to bear on them; and how, by knowing in what form they pass the time when not at work, we may, with least expense and most surely, turn them out from their shelters. And 
firstly, we will take the very injurious order of the: two-winged Flies, scientifically the Diptera.

\section{CHA P T R III. \\ FLIES (DIPTERA).}

Daddy Longlegs, Wheat Midge, Hessian Fly, Onion and Mangold Flies, \&c.

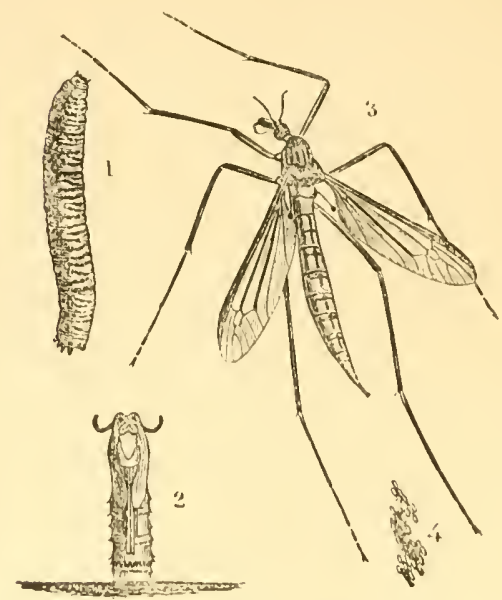

Fig. 37.-Daddy Longlegs: 1, larra ; 2, pupa-case standing up in the ground; 3 , fly; 4, eggs.

This order includes the Gnats and Corn Midges, also the Daddy Longlegs, of which the grubs are so. 
hurtful to many kinds of crops ; the Blowflies, which cause great waste to meat in summer; the Gadflies, and a very large number of other kinds, which, by means of their maggots, do boundless damage year by year to the roots of Cabbage, Onions, and other garden-crops, and likewise to the heart or stem of the growing corn; and many other linds of various habits.

All flies of this order have only one pair of wings; occasionally they are wingless. The hinder pair of wings is represented by a pair of appendages, often like a slender pin with a small head; these are known as "poisers" (scientifically, halteres), because they help, or appear to help, to poise or balance the insect. Some of these insects feed by suction, as in the case of the Gnats, to our great anmoyance.

The maggots, or larve, are fleshy and (with few exceptions) footless ; ${ }^{*}$ sometimes, like the Daddy Longlegs grub, they have a hard head, furnished with nippers or jaws; sometimes they liave a soft mass which answers for a head, commonly bearing a pair of hooks instead of jaws, with which they clear out the substance between the two sides of a T'urnip-leaf, or from the inside of an Onion-bulb, or other soft material in which they may be feeding.

The pupa-case, or chrysalis, varies in shape; in some linds, as of the Gnats and Daddy Longlegs, for instance, it is in shape much like the creature within, with its limbs folded; in many other kinds, as of the Onion Fly, Carrot Fly and others, the pupa-case consists of the hardened maggot-slin, which shelters the forming fly within.

- The maggots of two kinds of Flies (Wristalis and Helophilus) are peculiar for possessing seven pairs of what may be called a kind of claw-like feet. These magnots are known as "rat-tailed larvw," from the hinder part of the body beng lenuthened into a long slender tail-like tube, whereby they ean draw in air from above the damp or muddy places in which the margots lie. 
The flies of the division of the Diptera, including Gnats (Culicidce); and Tipulide, which includes Daddy Longlegs, and also Wheat Midges (Cecidomyice), are mostly of Gnat-like shape, with long legs, and long horns, and their grubs are to be found in the most various localities, some in water, some attacking wheat-blossom, or leaves of plants, some feeding at the roots.

The Daddy Longlegs, or Cranefly, figured in all stages at p. 36, likes damp surroundings, and thus we get.

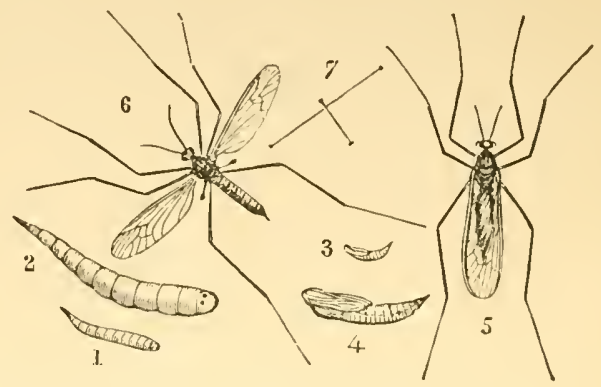

FIG. 38.-Winter Turnip Gnat: 1 and 2, grub;*3 and 4, pupa, natural size and marnified.

an idea of how to keep its numbers in check. The flies frequent damp overshadowed herbage, or marshland, or wet, neglected weed-growths, and in such places they lay their eggs.

The grubs thrive in such places, or at the roots of crops so long as the gromud is not too dry for them, and when they have fed for some months they turn to a pupa (see lig. 37, p. 36), which, by means of the spikes at its side, sets itself up in the ground conveniently for the fly to come out from.

The best way to forestall attark is to make the land unsuitable for egr-laying. Draining marsh-land, and rough mowing long grass or neglected herbage in

* The maggot fecds in decaying Turnip-bulbs. 
shady parts of pasture-fields, hedge-sides, and other like places, drives off a great deal of attack; but the chief difficulty is on land brolien up from pasture or clover-ley.

The eggs are mostly laid, towards autumn, in such localities (that is, pasture-fields or clover-ley); therefore, if these are merely broken up, without any measures having been previously taken to prevent egg-laying, or to kill the "Leather-jacket" grubs in them, it is no wonder that the next crop should often be totally devoured. Any measures that will serve either of these purposes are highly desirable.

Where pastures are to be broken up, it is a good plan to fold sheep on the ground and hand-feed them, thus making the ground obnoxious to the Cranefly for egg-laying, and also, by the trampling and soddening the ground with the droppings of the animals, destroying most of the eggs or young grubs that may chance to be on the surface. Heary dressings of hot lime are useful, and dressings of fresh gas-lime, or alkali waste, which kill everything they touch whilst in their caustic state, are an excellent preservative from attack. These two chemical dressings cost little (where they are procurable at all), and gradually turn to a manure of the same nature as gypsum."

Salt also has been found useful for dressing leys with in autumn. Laid on at the rate of 10 cwt. the acre, and ploughed in, it has been found to kill the couch-grass (a very serviceable means of prevention of insect-ravage), and there was no further trouble from either grub or wireworm.

Bush-harrowing does good, and paring and burning the surface is also an excellent remedy; but this has drawbacks, on account of the expense of labour, also wasting so much of what, in rotting, would have been fertilizing material.

Where eggs and maggots are in the ground, the most

* For amount of gas-lime that may be aplled per acre, and precautions to be observed in its use, see references in Index. 
hopeful method of meeting coming attack is to make all possible arrangements to push on a good growth, and, firstly, to secure a good start. This is one reason why deep ploughing is advised in breaking up leys. Some of the eggs and young grubs will thus be turned down too deep to hatch, or to make their way up again. Also, judging by what has been observed in other instances, those eggs which are well turned down, out of reach of the amount of air natural to them, will either not hatch or be so much retarded in date of hatching that the date of attack will also be retarded, and the young crop las a good chance to get well estublished before the grubs are ready. This first start is a very important matter ; if the young plant is stunted in its first growth, it most likely will never do as well as if it had begun heartily ; and this point should be borne in mind as one great method of counteracting injury from insect attacks to roots or leaves.

Get a good start, by using good, fresh seed, by proper treatment of the land beforehand, and, if you can, by burying the enemy so deep down that it will neither make its own way up at the natural time, nor be turned up again by after-ploughing or cultivating; and thus we get our plants so ahead in the race that we may hope to win.

This is a general principle, suited to all crops. But to return to special treatment of Daddy Longlogs grubs. If attack is found to be bad in growing corn, some fertilizer, such as guano and salt mixed, applied, say, at the rate of 4 cwt. the acre, has been found to do much good.

Nitrate of soda also acts well, both by benefiting the plant and injuring the grub. In experiments tried hy placing Daddy Longlegs grubs at a depth of one inch beneath the surface, it was found that where nitrate of soda at the rate of 2 cwt. the acre was well watered in, the grubs so treated were rery rolaxed, soft, and helpless, and so continued whilst observed 
and reported. This helplessness is a very important point, for thus the grub, instead of creeping away, is liept under the action of the solution good for the plant but bad for itself, and ultimately dies.

Special chemical applications, only intended to kill the grub, have (in the instances noted) been found not to do good, because they are so much weakened in passing through the ground that they are quite harmless by the time they reach the creature they were meant to kill. This has been the case with chemical acids, -carbolic acid, for instance; but whether we might not do good by regetable applications, such as that of mustard-calie, is a matter for future consideration.

The treatment may shortly be described thus:prevent egg-laying, if you can; bury eggs and grubs deep down out of the way; give your plant a good start, and lieep it well up under attack, if attack comes.

But, further, we should in this, and in all cases, look at the special habit of the pest. The Daddy Longlegs grubs cannot bear heat, light, and drought; therefore two linds of treatment, apparently quite opposed to each other, have been found useful, for they both bear on the above habits. Hoeing has been found useful, because thus, in dry sumny weather, the powdery, dry ground is just what the "Leatherjacket" grub dislikes. Also rolling at night, or at early dawn, does good; for then, during the cool dusk lours, we may catch many of the grubs on the surface, and they may be crushed by the Cambridge roller or Crosskill's clod-crusher; and rolling the ground firmly in this way likewise prevents some of the grubs "travelling."

There is one more point which has not been brought forward, but which, by watching the habits of the creature, 1 think might be very usefully worked in garden-ground. I find the grubs like to lie under a thin damp turf; they will collect in large numbers in such a spot. Probably it would answer well, in garden- 
ground, to lay slates, turfs, or tiles, and send a boy round every morning to clear what lay below. I have only worked this plan out myself on a small scale, but it is worth considering.

The above is one of our regular yearly attacks, especially to be looked for after a damp autumn and winter, because, as we have seen, danupness and moisture suit the Daddy Longlegs in all their stages.

The next of this gnat-like dirision of flies that may be considered is the Wheat Midge (Cecidomyia tritici),

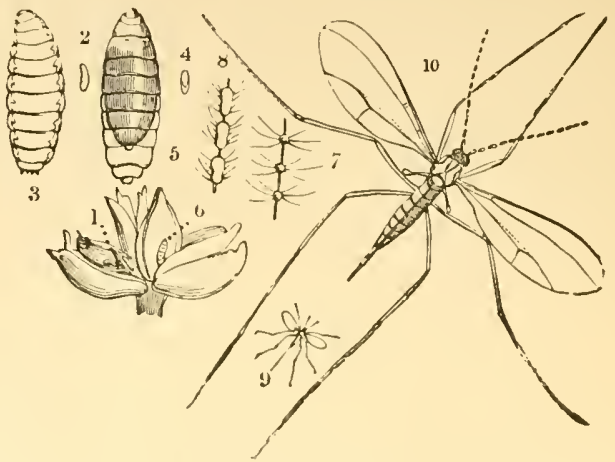

FIG. 39.-9 and 10, Wheat Nidge; 1-6, larre, nat. size and magnified; 7 and 8 , part of horns, magnified; infested floret.

the eggs of which produce the little orange or red footless grub known as the "Ped Maggot," often found in wheat-ears.

These little gnats are hardly more than an eighth of an inch long in the body, but have long legs and horms, and the female has a long ovipositor, as thin as a hair, with which she inserts her eggs in the wheat-florets, or those of such other linds of corn or grass as she may infest.

This operation is mostly performed in the evening, and we are indebted to the observations of Mr. Swanwick, of the Royal Agricultural College Farm, Cirencester, for the information that, just at the time of 
development, the flies were not only to be found attacking the wheat, but were to be found in great numbers in clover-land which was in wheat in the previous year, and also amongst rough grass at hedge-sides.

The maggots soon hatch, and feed on the germ or some part of the soft grain; they are very little grubs, hardly more than the twelfth of an inch long, yellow, orange, or scarlet in colour, and slightly pointed at the head. The loss they cause by feeding on the corn-grains sometimes amounts to as much as from one to about three sacks (that is, about half the crop) per acre. After they have left off feeding, some remain in the corn, and are carried with it; some remain in the stubble, or fall, or go down into the earth, where in time they change to chrysalids, from which the Nidge-flies come out about corn-flowering time in the next year.

In Canada, or where the weather can be reckioned on, and the date of appearance of the Wheat Midge can be reckoned on also, injury from attack is avoided by sowing so that the wheat shall flower before or after this special time. In one case the young grain is too firm for the Red Naggot to hurt it; in the other, the flower and germ are not far enough advanced for there to be anything to attack until the Wheat Nidge has passed away; consequently the corn is safe. We sometimes benefit in this way here by accidental circumstances, but we cannot depend on being able to arrange it as in less changeable climates.

Our best method of prevention is to destroy the Red Maggot (or the chrysalis, if it has turned to it) in its winter shelter. Deep ploughing, such as will turn infested stubble thoroughly down, will act well, for once deeply buried the Gnat-1ly either will not develop or cunnot come up again. It is not enough considered in these matters that we may by our own common knowledge often guide ourselves. If a weak small grub (so small that we can scarcely see it) has 
a weight of earth put on it, somewhere about as much as if at least thirty or forty yards deep of earth were placed on one of ourselves, it is very unlikely that, where it is not specially supplied with powers for piercing the ground, it will come up again as a grub; and the Gnat-Midge, if it does develop, certainly cannot make its way through.

This is one of the points that show us how to keep insects in check; we need often merely to consider

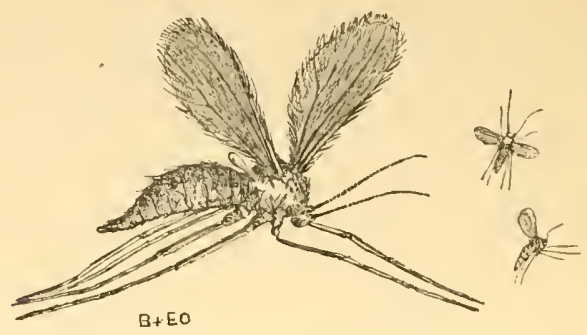

Frg, 40.-Messian Fly, nat. size and magnified.

just what is before our eyes and act on it. Once down, and left down (for, of course, if we bring the grubs up again by a second equally deep plougliung we lose our labour), we have in all probability buried the coming attack safely away.

All measures which will lessen the amount of couchgrass, or other wild grass (in which it either is lnown or believed, to lie in the heads, or shelter at the roots during winter), would help to lieep the amount of this Midge in check. Clearing and burning rough grass by hedge-sides is one method; gathering up the cornstubble and burning it, directly the com is liarvested, rets rid of whatever is at the roots; and also (and this is very important) all the dust from the threshing-marhine should be burnt uhere wheat is linow'n to be at all infested. The Red Maggot may often be seen in millions in this, and absence of attack has been found 
to follow the plan of carefully burning the infested dust.

The Hessian Fly (Cecidomyia destructor) is another of the Ceeidomyice which is very hurtful to various

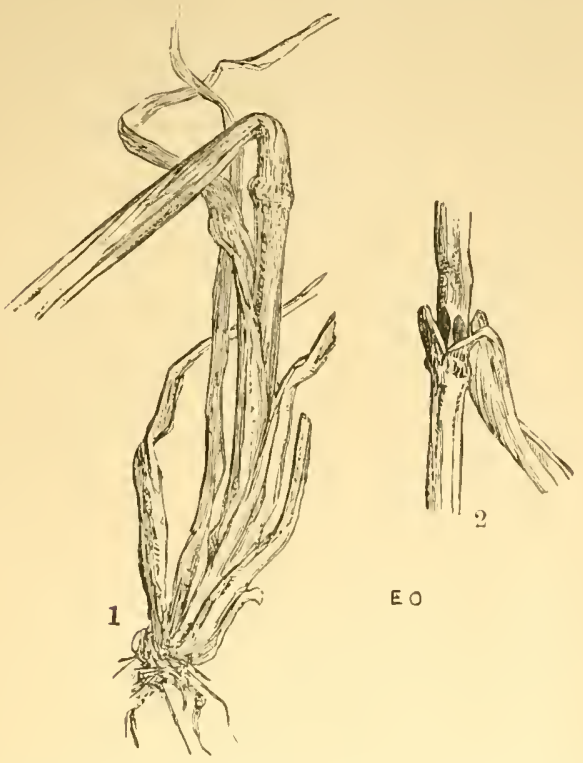

Fig. 41.-1, Barley-stem elbowed down by Hessian Fly attack ;

2 , showing position of "flax-seeds."

kinds of corn in America, and in various places on the Continent of Europe, and which was first observed in this country in the year 1886 . With us the attack is in some degree to wheat, but chiefly to barley; and it does not appear likely to be a serious crop pest here.

The perfect fly (Fig. 40, p. 44) much resembles a stout-made little brown gnat, about one-eighth of an inch in length, with one pair of smoky-grey wings, and with long horns. 
The attack may be to the young plant, but with us it mostly occurs only as a summer infestation to the growing stalk, where the small white legless maggot (which is much of the size and shape of the puparia given below, nat. size and mag.) feeds outside the stalk, but inside the leaf-sheath just a little above one of the knots. Commonly it is just above the second knot, but the attack may occur lower down at the first knot, or close to the root, or higher up above the third or fourth knot.

The mark of attack being present is the stem elbowing sharply down just above where the maggot lies. It does not commonly break, but, unless the straw is very firm, it bends at the weakened spot, and thus damage is caused to the fallen head, besides difficulty in reaping from the confused state of the straw. (See Fig. 41, p. 45.)

The maggot may live for about four weeks in this position, and then it changes, at the spot at which it fed, to a flat brown chrysalis, in

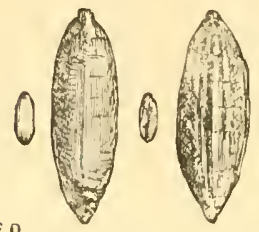

E0

Fig.42.- "Flax-seeds" or puparia in different stages of development, nat. size and magnified. size and shape and colour minutely resemibling a rather small and narrow flax-seed, whence the name of "flax-seeds" is commonly given to these chrysalis-cases or puparia. Within this hard outer husk the maggot changes to chrysalis, and the chrysalis to the perfect fly, but how long this may take depends very much on circumstances. It may occur, unter natural and firourable circumstances, so soon that the whole time occupied in the life of the fly from erge to development is only about forty-eight days; or under unfavourable circumstances it may be retarded. 'L'hus some of the Hessian Flies may come out in autumm on the fields; whilst some of the "Hax-seeds" threshed out, or stacked in the straw, or kept artificially for investigation, may very likely not liatch until Mity, or much later in the following year. 
With this attack, more than perhaps almost any other, we rest on the application of common agricultural measures, and dates of sowing, for the treatment which, joined to effects of the climate, has hitherto kept this infestation in check.

A great part of the damage caused by the maggot presence, arises from the stem being so weakened that it elbows down ; therefore all selection of kinds of seed, and all treatment calculated to give a healthy strong straw which will not give way under a moderate amount of maggot infestation, are direct means of preventing loss.

So far as wheat is concerned, our usual time of autumn wheat-sowing places the springing of the young plant well after the time when the summer Hessian Flies are about.

In the process of threshing, the so-called "flaxseeds " are thrown down with the light screenings, and can readily be gathered up with them and destroyed, thus putting an end to all chance of recurrence of attack from this cause; and, as hitherto we have only been troubled by the summer attack on the corn stems, and had no difficulties from the additional multiplication caused by a winter infestation on the young plants, it may be well hoped that this corn attack will not take the serious place in this country which it does in many other parts of the world.

These are three examples of the class of Gnat-like Flies (Tipulide, scientifically), which do as much harm. 'The Daddy Longlegs, of various species, are of the genus Tipula; the IVheat Midge and the Hessian Fly are of the genus Cecidomyia, which includes many other small Gnat Midges, some of which cause galls, and some of which feed, in the grub state, in Willow; and there are also other injurious kinds we cannot enter on now, but which, like the Willow Stem Midge, might be much lessened by noticing where they are in the chrysalis state. In this case, to burn worthless, infested shoots does much good and costs 
little; but in all such cases more care than is always thought of, should be taken to make out where the creature is, before going to expense in trying to destroy it, otherwise much cost may be incurred without the slightest use.

There is one other of this family (the Chironomus plumosus), of which the grub is known as the "Bloodworm," which deserves a word, not because it does any special harm, but because it gives a hint that where it is, affairs are not as they ought to be. This maggot is like a little bright red worm, and may be seen jerking itself about, or collecting in patches lilie a clot of blood, in water or on very wet mud, where there is a great deal of putrid matter and decaying leafage, on which the maggots feed; and they show the water is very foul. Therefore where the Bloodworm is seen in the water, or the clouds of Gnat Midges (to which they turn) above it, the water needs looking to.

In these histories we may scem, perthaps, to be merely considering crop attaclis, one after the other, together with some of the various measures which have been found serviceable for combating them; but though these are useful practically, I wish it to be particularly observed that it is not so much the detail of treatment of each case which is wished to be imparted, as the minciples on which the treatment is based. There are certain habits; certain times when the creature is inactive; certain treatment which will get rid of it equally in the egg, or the chrysulis state, and so on. Therefore, though I hope the short histories may be serriceable for fichl use further on, yet now these points are entered on chicfly as showing general methods of treatment that we may apply to all similur linds of attack.

Another very large dirision of this order of Diptera includes what may be lnown, or at least are commonly looked on, as true Flics, - such as are all more or less like a common House Fly in shape. They may be known from the Gnats and Gnat-Midges by luaving a 
short thick proboscis ; short horns of only three joints, having a bristle at the tip; and legs and wings of moderate length. The maggots often taper to the head, and are larger, and as it were cut short off, at the tail, which is often furnished with tubercles, and also with a pair of large spiracles, by means of which the maggot can draw in as much air as it needs by letting the tail project from whatever moist matter it is lying in. The head is a soft mass, furnished with

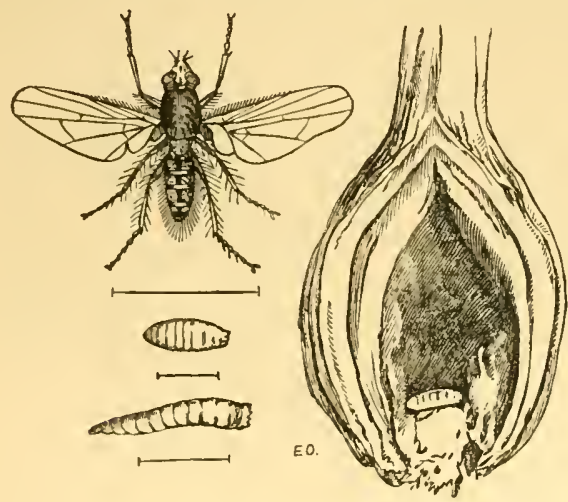

Fra. 43.-Onion Fly, maggot and pupa; magnified. Pupa in stored Onion. Lines showing nat. size.

hooks instead of jaws, by means of which the creature can draw, or reap, into itself the soft substances whereon it feeds. The head can be so completely withdrawn into the maggot as not to show externally. (For details see Fig. 47, p. 57.)

The formation of the pupa-case, or puparium, is a most important matter practically. We know it as the small brown oval case, about an eighth, or a quarter, of an inch long, which we find by maggoteaten Onions, or Cabbage-roots, or sometimes in dead animals. It is formed of the hardened skin of the maggot. This draws up, and within it the fly forms, 
and from it, in due time, cracks its way out; but meanwhile the coming Fly is wonderfully safe in all circumstances. It is in a little chamber, which protects it from drought and wet and evil influences; and consequently the common crop Flies are not as easily to be got rid of in the pupa or chrysalis state as many other attackers.

However much our crop Flies may differ in the part of the plant the maggot feeds on, there are many which are so much alike, in the maggot turning to the above kind of pupa, in the ground; that there are

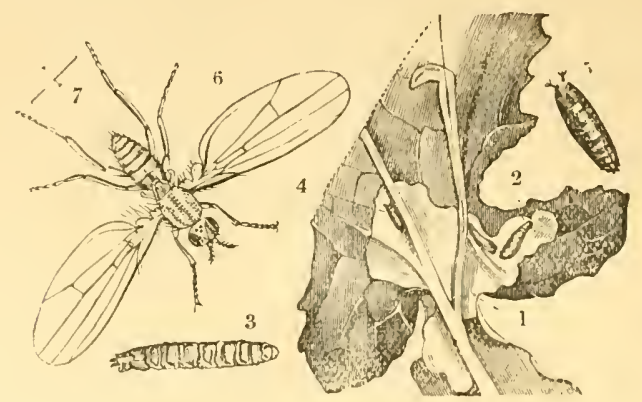

Fig. 44.-Turnip leaf-miner, Fly maggot anil pupa; nat. size and magnified. Blistered leaf.

some means of prevention which apply equally well to many kinds of attack.

The Onion maggots feed in the putrefying bulbs, and then usually leave them, and turn to brown oval pupx in the ground near the destroyed bulb, though sometimes they are stored in it during the winter.

The Cabbage-root maggots also turn to brown oval pupe in the ground, and so does the maggot of the Carrot Fly. 'This maggot, when feeding, may be seen with its tail sticking out of the rusty-coloured injured parts, which give this attack the name of rust; and in due time we find the brown pupa-cases close by. (See Fig. 22, p. 27.) 
The same happens with the maggots of the Celery or Parsnip Fly, and of some of the Turnip leaf-miners, which feed between the two sides of the leaf; and also to a great extent with the Beet Fly (Fig. 45). The pupæ of these are, respectively, either entirely or to some extent, to be found in the ground near the attacked plant; and this is one reason of the great use of rotation of crops as a means of prevention.

Where there has been an infested crop in autumn, there will be many of the pupa-cases in the earth; when spring comes the Flies crack their way out of
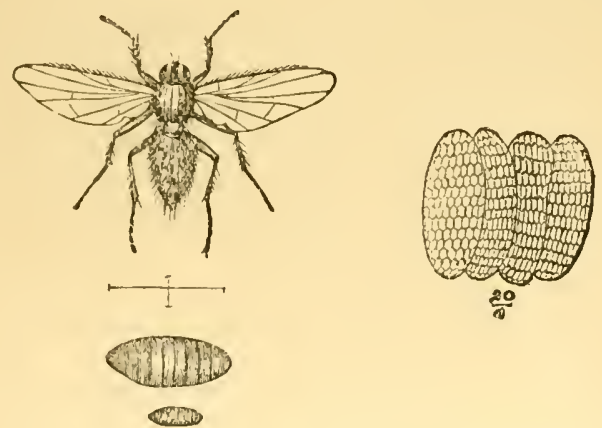

Fig. 45. - Beet Fly and pupa, mas. and nat. size; cluster of eggs, magnitied.

their husks, or puparia, and then are all ready to lay their eggs on their own food crop, if it is on the same place, or near. This is an important point in field Cabbage growing, where Cabbage crops are often repeated time after time, and also in Onion and Carrot growing. We may bury many of the pupa-cases, just as we can bury Daddy Longlegs or Wheat-midge grubs, but we must be even more careful not to bring them up again before the time for the Fly hatching out of them has passed, for the cases are firm and strong, and the Fly within them is so well protected that it will bear a deal of burying, and moving about, without any damage. 
The Onion, Cabbage, Beet, and Celery Fly, and' some others, have several broods in the summer. This is the reason why it is an object to check the very first attack, even by destroying part of the crop. Often by raising the attacked Onions with a spud or a. broad knife, or something that will quite certainly bring up all the maggots, we can check the attack, and destroy the parents of what would in a few weeks have been a devastating horde. Or it is a better plan still to pour a few drops of carbolic acid carefully on the destroyed bulb. This kills every grub it touches, and does not encourage further attack by loosening the soil, or bruising good bulbs. We may sometimes. check Celery, or Beet and Mangold Fly attack, by cutting off bits of leaf, or drawing plants which are infested. But we should be sure to destroy the drawn plants. If they are merely left on the field, or thrown to the rubbish heap, the maggots which are full grown will turn to pupæ, and the Flies develop as well as if nothing had been done.

In all cases of maggot attack to roots or bulbs, it. should be borne in mind that if we can keep the Flies from laying their eggs on, or very near, what is their maggot food, the plants will be to a great extent safe. One at least of the Onion Flies lays her eggs on the bulb, apparently on the lowest part she can reach. If Onions are knocked about, and left bare in hoeing, they are at the mercy of the Fly, which in this and other cases appears attracted by the smell of the injured crop.

With Onions, and also with Carrots, attack very often follows on thinning; but the matter may be met. I have found that in garden treatment, where Onions were in rows, earthing them well up above the collars answered well; and with Carrots it has been found, by various good growers, that thinning so early that the operation did not throw the ground open was a successful treatment, particularly if followed by copious waterings to "settle" the ground. 
These are points of general application, - a sort of physical-force treatment. Bury the enemy beforehand if you can; but if you have it in the ground where it can do harm, then (as far as you can), keep your crop grubs, and your coming crops, at a distance; and in cases where the Flies require to lay their eggs on a bulb, or to go down cracks to get at the roots, then think over the matter well as to whether some such

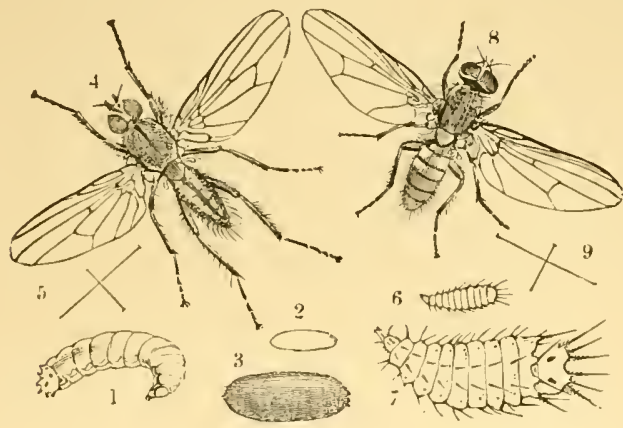

Frg. 46.-Cabbage and Potato Flies: 1-3, maggot anil pupa-case of Cabbage Fly ; 4 and 5, Root-eating Fly; 6-9, Potato Fly and maggot: all magnified, with nat. size.

way as I have suggested (or some much better way, which you may think of for yourselves) cannot be managed so as to defend the plant,- to lock the door, as it were, in face of the thief. The Fly has got to lay her eggs, and then she will die; and if we can protect our plants so that (as I have seen with Onion Fly) the eggs have to be dropped at haphazard, where they would come to nothing, it saves much future trouble.

But besides methods of prevention based on protecting the plant from egg-laying, or on burying down the infestation, or carrying it away and destroying it, something may be done by noticing, with regard to some of the common crop fly maggots, that they not 
only live on various kinds of plant roots, but also in dung; and the question therefore comes whether the use of animal manure in a state, and at the time, when it may bring maggots with it to the coming crop, is desirable. We need plenty of good strong manure if the crops are to grow, but still there are different ways of treating it before application, and different times of applying it.

The great German authority on Flies, Dr. Rudolph Schiner, says of the division of Anthomyia, to which the Beet Flies, Onion Flies, and Cabbage Flies belong, that in many cases the larvæ live in vegetable substances, and also that many seek out rotting and putrefying matter.

It has been found that the "Root-eating" Flies, the Anthomyia radicum (Fig. 46, 4), of which the maggots feed on Cabbage and Turnip roots, inhabit dung by thousands, and especially frequent nightsoil ; also that they attack crops manured with horsedung and bone-dust, whilst on ground close by plants manured with superphosphate are not at all attacked.

Another kind of Cabbage-root maggot, that of the A. floralis, was found by myself in earth round partly decayed Clover-roots.

The spiny maggots of the Anthomyia tuberosa, the Potato Fly, as it was named by John Curtis (figured with the perfect Fly, at p. 53), have been found swarming in rotten Potatoes, and also, as well as their chrysalids, in ground often occupied by Cabbage.

The maggots of the Shallot Fly (A. platura) have been found in great numbers in night-soil; and I have a note of attack of Onion maggot having showed itself in the greatest number's where cow manure liad laid for a considerable time before being dug in. All the plants, where, or near to wliere, the heaps had been, were destroyed by the 1st of July.

From these notes it would appear that, whether 
we start Fly attack or not, by much use of animal manure, at least where infested Cabbage has grown we are not likely to get rid of the grub from the ground by simply digging in stable or cow-shed manure; on the other hand, we find chemical dressings have cleared it. We have instances of grub attack not having taken place in an infested district, or having been cleared out where it existed, by the use of gas-lime, or hot lime. The gas-lime was carted on to the land during frost, and presently spread; and the land on which this was sprinkled escaped attack, whilst on that which was not dressed the crop was lost by maggot. Where the crop has been cleared by maggot, it has been found that a handful of hot lime mixed with the soil, before dibbling in the new plants, prevented any new attack. Superphosphate of lime is also recommended in continental practice.

The Fly needs a suitable material to lay her eggs in, with some instinctive prospect of food for the maggots, and the lime does not present her with either one or the other: the maggots have a poisonous material instead of food added to the soil, and altogether the position is made quite an unnatural one for the attack.

Where a plentiful supply of farm manure is used, we find (with various crops subject to Fly attack) that it answers well to prepare the ground and put the manure in during the previous winter. With Onions it has been found the most successful plan of growing is to work the soil deeply in the autumn or winter, and put a good layer of manure at the bottom of the trench, or work it well into the soil. The surface is laid up rough or ridged for the winter, and when sowing time draws near is levelled. Thus there is no fresh farm manure on the surface, although some fertiliser, such as soot or wood-ashes, lime, \&c., is usually strewn on the surface, or otherwise applied, at sowing time. With Carrots it has also been 
found to answer best thus to prepare the ground beforehand.

In this way we join many points that are wanted. It is very difficult to say, in Insect prevention, use this or that treatment; but we should bear in mind that there are certain points we want to bring about, and the chief one of these is to keep the crop safe. For this many arrangements must go on together: we need a fertile soil, but at the same time we need that the fertility should be of a kind adapted, if possible, to feed the plant, rather than the insect; and therefore in many cases chemical dressings are the most serviceable. 


\section{H A P T E R I V.}

\section{FLies (Continued) AND FLEAS.}

(DIPTERA AND APHANIPTERA).

Gout Fly, Cattle Flies, Flea, \&c.
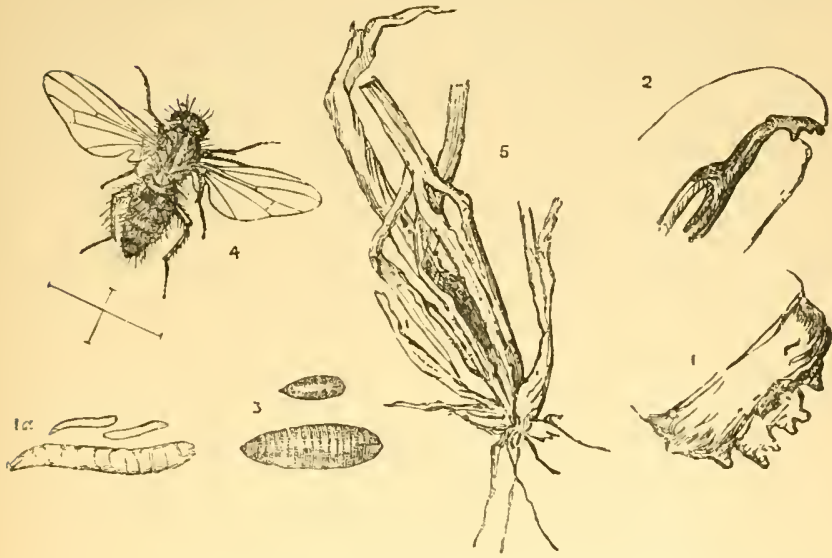

FIG. 47.-Wheat-bulb Fly (Irylemyia coarctata), magnified, and lines showing nat. size; maggots and chrysalids, nat. size and mag.; mouth apparatus, and extremity of tail, with tubercles, mag.; infested plant.

Looking at the many hundreds (or perhaps it might rather be said thousands) of species which exist of British Flies, and also considering the great resemblance which many of them, as well as of their maggots respectively, bear to one another, it is plainly impossible for anyone who does not give special attention to the subject to know more than a limited number with certainty. But still something may be done towards gaining a useful linowledge of them, by 
taking them in large divisions according to their habits, as well as their aprearance.

We have glanced at the habits of the Gnat-like Flies in their attacks to Corn and pastures, \&c., and at what we may describe as food-crop and manurefeeding Flies, and have seen that many of these Crop Flies are alike in the habit of going through all their changes or conditions-egg, maggot, pupa, and flyquickly in summer (so that there may be two or more generations); and that the pupæ of the last autumn brood often lie (if we will allow them) safely, and uninjured by cold or common amount of moisture, during winter, so long as they are in their own natural shelters; and in the case of these insects we know where they are all the year round.

But besides these, there are some kinds of Corn Flies of which (in regular course) there is a winter brood and a summer brood; the summer brood feeding in maggot state in the ear, or on the upper part of the stalk of Barley, Wheat, or Oats as the case may be; and the winter brood living in maggot condition in the heart of the young plant. To keep these attacks in check we need to know where both the winter and the summer attack is to be found, and this is just what is not the case regarding om linowledge of the habits, in this country, of the Gont Fly, which is often very injurious to Barley, and the Frit Fly, which is sometimes very injurious to the young Oat plants. In the first case we need to know the common winter locality; in the second, that of the summer brood.

The small striped Yellow Ribbon-footed Corn Fly (Chlorops teniopus), sometimes linown as the Gout Fly, lays its eggs on the growing Barley stem, at or near the base of the ear, and the magrot eats a furrow down the stem to the first linot. Consequently the growth becomes diseased or stunted, the ear often does not develop, and remains in its sielled sheath, and within the sheatl the maggot turns to a reddish brown pupa; and when the Barley has been stacked the 
little Flies sometimes are to be found by handfuls in the stacks. Now comes the winter history, which is very different. These autumn Flies have been found and recorded, in continental observations, to lay their

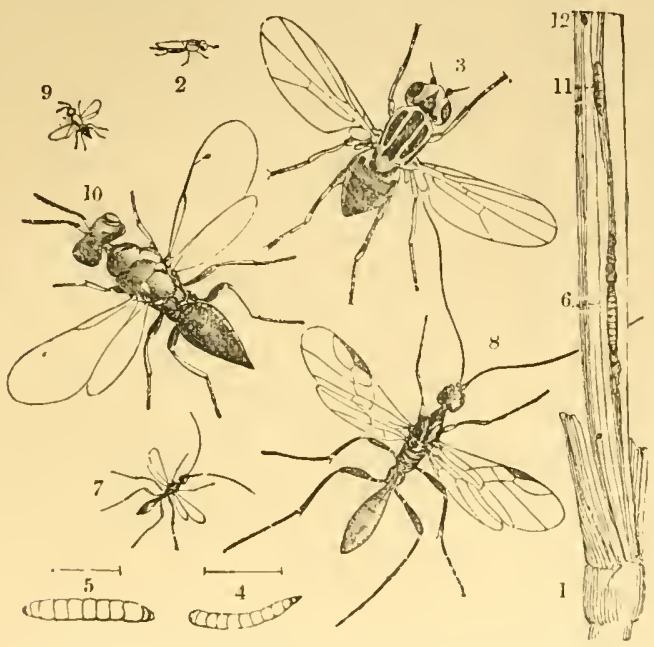

FIG. 48.-Gout Fly, grub and pupa; nat. size and magnified; with infested stem. 7, 8, 9 and 10, Parasite Flies; nat. size and magnified.

eggs on autumn-sown corn, or on wild grass; the maggot, when hatched, pierces into the heart of the young plant, and there it passes the winter. It is stated that when spring comes the unattacked parts grow as usual, but the attacked portion only produces a diseased growth of broad leares and thickened shoot, which commonly perishes. The maggot turns to the pupa within, and from this there comes out the Gout Fly, somewhere in March or April, in due season to lay its eggs and begin the summer attack.

This fact has long been linown, but as far as I am aware has never as yet been recorded in England save once, and only on the small scale of derelopment 
from a plant or two of wheat. But it is important to know that the same species of maggots can live as maggots in the young corn plants during the winter, and in the summer feed on a totally different part of the plant. In this case spring-sown Barley* is manifestly safe from attack during its early growth; and clearing away the masses of wild grass, which often are allowed to grow in strips several feet wide by hedges, would get rid of winter-quarters of the Fly, which frequently may be found especially infesting the corn by these grass headlands. It is often also found to infest patches, or an acre or more, of wet land in a field, where the rest of the crop is free; and here we get to the point of effect of the state of the land, or of special manure on amount of Fly attack.

The extent to which the condition, or special treatment of land, may influence amount of presence of some kinds of crop infestation, is markedly shown in the case of the Wheat-bulb Fly (see Fig. 47, p. 57).

In this case the harm is done by the little white legless maggot feeding within the young Wheat plants early in the year, and thus destroying the infested shoot. The presence of the attack is observable from the withering of the attacked shoot, and is noticeable by the beginning of April, or some weeks earlier. About the middle of May the maggots may be found changing to the chrysalis state in or by the destroyed shoot, and some weeks later the hairy greyish Fly appear's from the chrysalids.

But the remarkable point of this attack is that it is especially prevalent after fallow, or bare fallow, or where land has been exposed to the sun, as where a potato crop has been cleared early, or there have been

* Since writing the above in 1883 , I was favoured by an observation from Prof. W. MeCracken (of the Royal Agrieultural College, Cirencester), that on the College grounds the portion of the Barley sown in March, 1889, was practically free from injury; that sown on April 6th was injured to the extent of 2 per cent. ; and that sown on May $3 r d$ to the extent of not less than 20 per cent.-E. A. O. 
bare patches where Turnips have failed, or, again, where a preceding crop may have been mowed so close to the ground as to expose the ground to light and warmth. There does not appear to be any record of a summer brood being found of this Fly, which would give, as in the case of the Gout Fly or Hessian Fly, perfect insects in autumn to infest the young plants; and after digest of careful observations of several years, there appears every reason to suppose that the eggs of the Wheat-bulb Fly are laid in exposed land, and that it is the maggots from these which infest the autumn-sown Wheat.

Here at once we have a clue to prevention. Do not sow autumn wheat after bare fallow, or where ground has been exposed during summer, in districts liable to this attack. Also it would be useful to plough with a skim-coulter attached, so as to turn down the surface of the land, and then bury it away so that the infestation is not able to make its way up again. Deep ploughing is a good preventive, but if the slices lie hollow, then it does little or no good; the eggs or maggots are not much altered in situation, and when they have gone through their changes, the perfect insects may very likely be little lessened in number by the treatment. The great point is to put the insect. vermin so deep down that it cannot come up of itself; nor yet be brought up again by succeeding measures of cultivation.

The two preceding attacks respectively affect (or chiefly affect with us) Wheat and Barley; but there is another, that of the "Frit Fly" (Oscinis frit), which, by reason of its maggots feeding in young Oat as well as Wheat plants sometimes, as in 1888, does a deal of mischief in this country. The young maggot injures the plant much in the same manner as the Wheatbulb maggot, and is very like it in general appearance. The little Fly is rather under the eighth of an inch long, and of a bright shining black.

In this case we possibly have an example of what 
certainly needs care in some others, namely, the danger of infestation being imported. At present we have little knowledge of summer attack taking place in this country, but in both Sweden, and Bohemia, summer attack has been found respectively in ears of Barley, and amongst grains in Oat heads; and where there appears to be a chance of infestation being present, in the form of little brown chrysalis cases, not unlike those figured at $3, \mathrm{Fig} .57$, it might be well to try " pickling" the seed before sowing.

Just glancing over some of the main points of prevention for some of the corn insect attacks noticed in this, and the preceding Chapter, it will be seen that there are various measures easily practicable, and often lying quite within common farm treatment, at little additional cost. For clearing or preventing attack on ley or pasture before breaking up, handfeeding sheep on the ground is of use; for prevention of several different corn attacks, attention to date of sowing has been found effective; also regard to what has been the previous state of the land, may make all the difference between presence or non-presence of subsequent attack; infestation may be got rid of simply by gathering it up from the threshing-machine and burning it; or, if presumably remaining on the surface of the field, may be ploughed under, so as to bury it safely down. 'I'hese points may appear very simple, but it is on attention to these, or similar principles, that we depend for safety. Each special crop insect, has its own special history, its own particular way of getting its living out of the crop, which we also want for our own benefit; and the better we know what its life habits are, the better we are likely to be able to protect ourselves against its ravages. But whether we know the details or not, such broad principles as those noted above are always useful to bear in mind.

We have now glanced at the method of life of some of the order of 1)iptera, or two-winged Flies, which are especially injurious to corn and pastures; and that 
of what we may describe as food-crop, and manurefeeding Flies; but still (arranging them for convenience of farm reference, according to the special objects attacked) there is another most important kind to be considered, including the Flies which are injurious to Horses, Cattle, or other live stock.
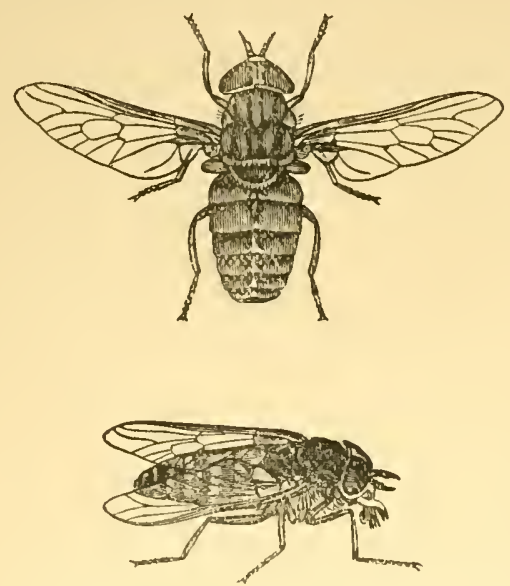

FIG. 49.-Gad Fly (Tabanus bovinus).

Gad Flies, Warble, and Bot Flies, Forest Flics, de. - The family of the Tabanide, or Gad Flies, which are injurious as bloor-suckers, include some of the largest Flies which we have in this country, and cause injury by piercing into the skin (it may be of cattle, or it may be of ourselves) with the lancet-like apparatus which they carry in their proboseis. In shape they may be described as like common Flies; but the great dark brown Fly striped across with yellow, figured above, known as Ox Gad Fly, is sometimes as much as an inch and three-quarters in the spread of the wings.

From the circumstance of the larva or maggot of 
the Tabanus bovinus having a distinct horny head, and the pupa being naked and incomplete (that is to say, in some degree resembling the perfect Fly), it will be seen that technically this family is nearly allied to those of which the Tipula (Fig. 37, p. 36) may be taken as a type. But (as above mentioned) the points under consideration, being the animals or plants attacked, I notice the Gad Flies here together with the other Cattle Flies.

With regard to the habits of the genus Tabanus whilst in maggot state, it is said by Dr. Rudolph Schiner, one of the chief authorities on the Diptera:"The larvæ live in moist earth, or in sand, or under decaying leaves and stems in damp places. The Flies are often found in cattle pastures, and by roads and paths, where they rest on neighbouring trees, and lie in wait for horses and cattle, to which the blood-sucking females are very troublesome. The males also frequent flowers, or hover, especially in the morning and evening, by roads, in the sunshine." *

As in this case it seems impossible to lessen attack by destroying the maggots, the next best way of saving the cattle from annoyance would appear to be, moving them from pastures by streams, or such localities as the Flies frequent, to more open and dryer land, where the state of the ground would not suit the Gad Fly maggots, and the Flies would not find the trees which they love to lurk amongst. In case of dressings being desirable to ward off infestation, the same that are known to answer in the preventing attack of Warble Fly would be useful.

The large family of the Estrida, popularly known as Bot Flies, differ from the Gad Flies, mentioned above, entirely, in their method of doing harm, inasmuch as, generally speaking, the mouth of the LEstridce is olsolete, only represented by a few minute

* 'Fauna Austriaca, Diptera,' vol. i., p. 29. (The grubs or maggots are to be found in grass-land, especially where it is wooded, from September until May.) 
fleshy tubercles; also the maggots of this family of Flies live within some part of the animal that is attacked. Prof. Westwood notes three principal differences in their habits:- Some live in tumours beneath the skin; some attack the cavities of the

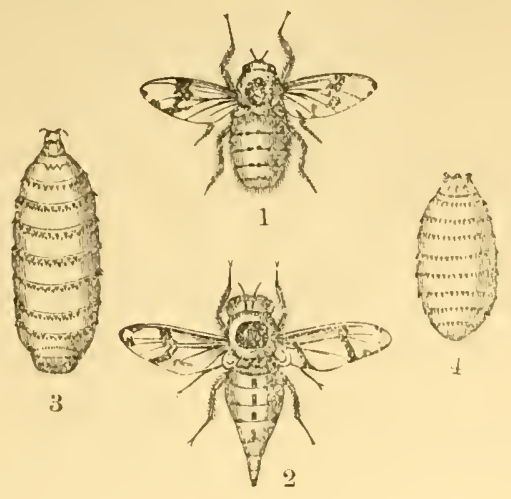

Fig. 50.-Horse Bot Fly, 1, male ; 2, female ; 3, maggot ; 4, chrysalis, nat. size, after Bracy Clark.

head, which are reached through the nostrils; and some are gastric in their attack, by the maggots being introduced into the stomach.

These Flies belong to the family of the CEstride; and the kind we are about to notice (the Gastrophilus equi, or Horse Bot Fly, see figure above), are about the size of a house Fly, or rather larger, and are somewhat gaily coloured with yellowish and dark markings, and very hairy.

In the case of this Horse Bot Fly, the female hardly touches the animal, but, whilst lightly flying to and fro, places the eggs on the hairs, until the very numerous supply are laid. These are fixed by a lind of sticky moisture on the shoulder, or on the mane, inside the knee, or on any other part selecterl. The maggot forms within the egg, and when it is ready to 
hatch (which may be in a period of from about five days to three weeks), the warmth and moisture of the hor'se's tongue in licking the infested hair, causes the kind of lid or eap to open or crack, and the maggot within sticks to the tongue, and is thus gradually transferred to the stomach. Here the maggots fix themselves to the mucous membrane * by means of two dark brown hooks, one of which is placed on each side of the slit which serves for a mouth, and there they nourish themselves by suction, and are considered to pass from eight to ten months in maggot state, attached by their mouth hooks to the lining membrane of a portion of the stomach.

Sometimes there may be only a few of these maggots present; sometimes (as I Fig.51.-E $\alpha$ grs of Horse Bot Fly, nat. size and magnified (after Bracy Clark).

have seen them myself) they are present in such numbers as to lie close up against each other over a large patch of surface, so that it hardly seemed possible to find room for auother amongst them.

Here they live until, when full-fed, they loose their hold; and, after being thrown to the ground, turn to a brown pupa, from which the Fly comes out in a few weeks.

For prevention of this attack, such treatment as combing, brushing, or clipping hair, so as to get rid of the eggs, is sure to be of use. Also the application of soaps, or washes, with scents deterrent to insect attack; and likewise freedom to the horses to shelter in sheds from Fly attack in the heat of the day. liemedies fall within the province of the veterinary adviser, as special advice is needed for their safe application.

* In observation of this infestation it is very important for the student to notice accurately to which portion of the stomach the larva are attuchel. 
The Ox Warble Fly, or Bot Fly, is a two-winged Fly, upwards of half-an-inch in length, so banded and marked with differently-coloured hair as to be not

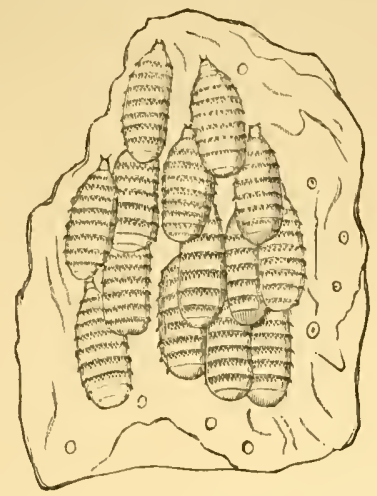

Fig. 52.- Maggots or Horse Bots attached to membrane of stomach, after Bracy Clark.

unlike a Humble Bee. The face is yellowish; the body between the wings yellowish before and black 3ehind; and the abdomen whitish at the base, black

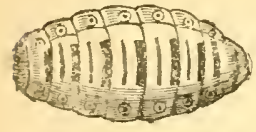

2

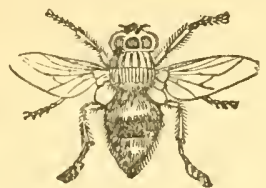

1

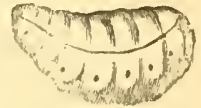

3

Futi. 53.-1, Ox Warble Fly; 2, maggot; 3, chrysalis.

in the middle, and orange at the tip. The female is furnished with a somewhat telescope-formed extension of the end of the abdomen which acts as a long egglaying tube, and the egg is white and oval, with a small brownish lump at one end.

On hatching from the egg, the maggot is not of the 
thick oval shape to which it afterwards changes, but is almost worm-like in shape, and is furnished with a pair of cutting-forks at the mouth end. By careful examinations of sections of hide in the very earliest stage of attack, a fine channel or perforation will be found leading from the outside of the hide, right.
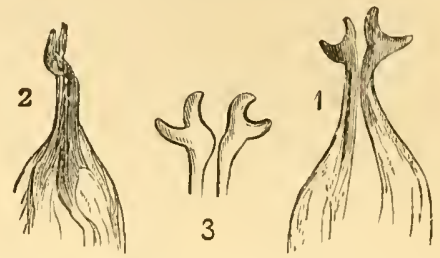

FiG. 54.-Mouth-forks of young maggot, much magnified.

through it down to the under side. Here the young maggot will be found, and by gentle pressure the cour'se of the maggot channel may be clearly traced

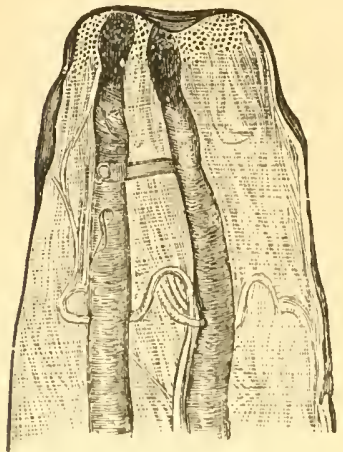

Fia. 55.-Breathing-tubes of maggot, magnified. by the little drop of blood which (in my own observation) I have found can readily be forced along it from the larval working below, till it stands as a minute drop on the outside of the hide. This chamnel I have found to be rough and jagged at the side, thus showing it was gnawed or torn (not cleanly pierced as by an ovipositor), and the direction was very various, so as even to be much curved.

'The maggot gradually increases in size, still lying with the tail end uppermost, or nearest the opening in the hide; and as it grows it presses back, and ofens the surrounding tissue, till it lies with the tail 
extremity in the opening of the boil-like swelling, commonly known as the "Warble."

Here it draws in air through what look like two small black spots in the tail, but which are really the spiracles, or masses of minute breathing openings, by which air is admitted into the breathing-tubes or trachece of the maggot. It feeds by sucking in the putrid matter flowing into tlie cavity its presence bas

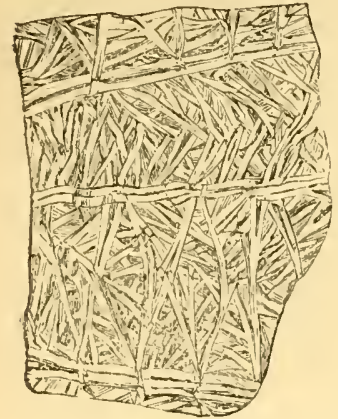

FiG. 56.-Muscles of magrot, much magnified.

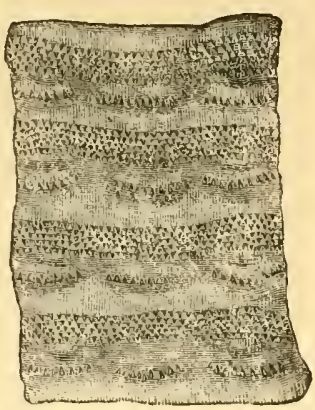

Fig. 57.-Prickles of maggot, much magnified.

caused, and there it remains until it is full grown, that is, about an inch long. This may be at any time from May to much later in the season, and then, with the help of the rows of prickles with which it is furnished outside, and the powerful net-work of

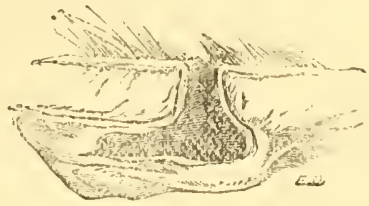

Fig. 58.-Section of Warble, after soaking in water.

muscles with which it is furnished within the skin, it drags itself through the opening of the Warble, tail 
foremost, and falls to the ground, where it finds some shelter, either in the ground or under a stone or clod, where it changes to a chrysalis. The chrysalis is dark brown or black, much like the maggot in shape, only flatter on one side; and from this brown husk the

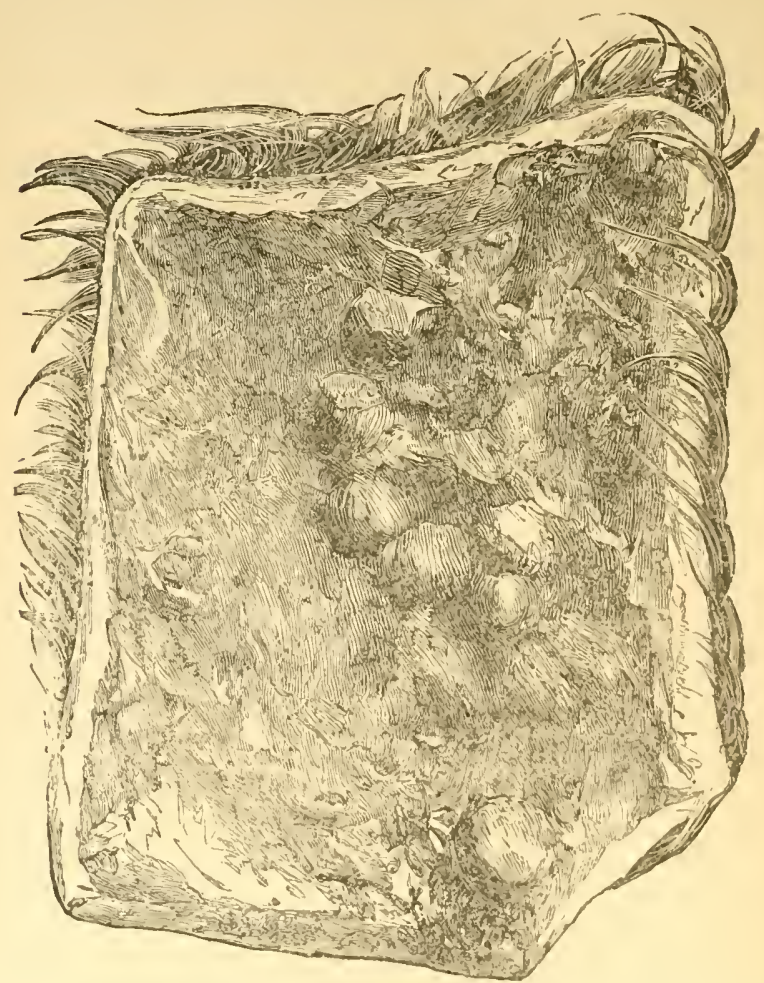

Fig. 59.-Piece of uniler side of Wrirbled hide; warbles abont half size. From a photo by Messrs. Byme, Richmond, Surrey.

Warble Fly comes out in three or four weeks, but this length of time is increased by cold weather.

Fig. 58 shows a section of a Warble cell in a hicle that has been removed from the animal, so that the 
condition immediately below the hide is shown; and the kind of false skin which has formed orer the upper part of the perforation, and prevents proper healing (and consequently damages the hide for trade purposes), is also shown.

Fig. 59 shows the under surface of a piece of hide in which the Warble maggots are as yet very far from full grown, but still it gives some idea what the state of things would be when each of the maggot-swellings was twice, or more than twice, the size figured ; but it does not at all convey the diseased state of the under side of the hide caused by the cells full of putrid matter and the inflammation.

Where this is serere, the condition of the surface of the carcase beneath linoun as "licked beef," or" "butchers' jelly," is to be found, which is a very serious drain on the health, condition and quality of the animal; thus well describea by $\mathrm{Mr}$. C. E. Pearson, wholesale butcher, Sheffield:-"I may say that the effect of Warbles on the carcase is more serious than can possibly be imagined by the outside appearance of the beast. . . . . The carcase of beef assumes a nasty yellow colour, and also a soft flabby appearance on the outside rind of the beast (where the Tarble has been in operation), so much so that the carcase has in some cases to be pared down to the Hesh to make the appearance of the animal at all presentable for the market, causing thereby a grievous amount of loss to the butcher. I am speaking from practical experience, killing on an arerage twenty beasts or more a week."

On applying to $\mathrm{M}_{\mathrm{r}}$. Hy. Thompson, M.R.C.T.S., of Aspatria, Cumberland, who has long devoted much attention to warble attack, for an exact description of the damage, he replied:- "What causes the damaged meat or beef is the chronic inflammation set up by the Warbles in the slin, which extends to the connective tissues, thence to the flesh, producing the strawcoloured jelly-like appearance of a newly slaughtered 
carcase of beef, which in twelve or twenty-four hours, when exposed to the air, turns a dirty greenish yellow colour, and thus spoils the beef, having a frothy discharge oozing from the surface, with a soapy-like look."

This state of things is only too commonly to be found; in the words of $\mathrm{Mr}$. John Child, manager of the Leeds and District Hide and Skin Co. :- "In the worst part of the Warble season, I could get you bucketsful of inflamed tissue (commonly called by the butchers, 'jelly'), cut and scraped from the carcase after the hide is taken off."

Its prejudicial nature in all points of view is thus shortly given in the last words of some observations with which I was favoured by $\mathrm{Mr}$. John Penberthy, Prof. of Pathology at the Royal Veterinary College, Camden Town, N.W., regarding some specimens on which I had requested his opinion:-_" The material is not fit for human consumption. I think it very deleterious to the health and comfort of the affected animal."

The yearly loss from this attack is enormous. Firstly, there is the loss on milk, and on many other points of damage consequent on the wild gallop of the cattle when terrified by the Fly. Secondly, there is the loss on condition of the infested animal. Every warbled hide is a sign of so much out of the farmer's pocket, for the food he spent in feeding grubs in his cattle's backs, which should have gone to form meat and milk, instead of being wasted in foul maggot-sores.*

* The following is one note taken from many which I received showing the loss to the eattle owner by waste of food not formed into ment by the warbled beast, as well as deficieney of reeeipt per stone on the carease and per pound on the hide. Mr. J. Sparkes, Wearhead, Darlington, wrote me, on the 1 oth of April, that he had lately sold to a buteher a heifer, whieh turned out a mueh lighter weight than was expeeted from the extra good food. The animal turnel out to be badly wirbled, and "down the spine frothy, loose, and mattery, or in a sort of jelly," and some of the beef has to be seraped before sending it ont. The loss on hide at $1 d$. per pound would be about 5 s. on the hide; the loss on beef, the animal being soli by the stone, fell on the owner. 
Thirdly, there is the loss falling mainly on the butchers, consequent on damage to surface of carcase known as "licked beef" or "butchers' jelly." Fourthly, there is a great loss on the injured hides. The two following returns, from Newcastle-on-Tyne and Aberdeen respectively, taken from a number of returns from hide or cattle companies, \&c., with which I was favoured in 1888, give some slight idea of the loss going on simply on this one item of perfectly needless waste. The following is from Newcastle-on-Tyne:-

"In a period of twelve months, 102,877 hides passed through the market; of these, 60,000 were warbled. Loss estimated at $£ 15,000 . "-J$. McG.

"In five monthis, from Febluary 3rd to June 24th, 61,103 hides passed, of which 14,830 were warbled. Loss, £2873."-IV. M. \& Son, Aberdeen.

The abore loss, in all its detuils, is wholly unnecessary. By the use of the simple measures mentioned below, we have now found, from the experience of our leading farmers, cattle owners and veterinary surgeons, during about nine years (that is, since attention was first directed to the subject), that the attack may to all practical purposes be stamped out.

Squeezing out the maggots is a sure method of getting rid of them; but they may be destroyed easily and without risk by dressing the Warble with a little of McDougall's smear or dip, or by a little cart-grease and sulphur, applied well on the opening of the Warble. Mercurial ointment answers, if carefully used-that is, in very small quantity, and only applied once as a small touch on the Warble; but where there is any risk of careless application it should not be used. Any thick greasy matter that will cholie the breathing-pores of the maggot, or poison it by ruming down into the cell in which it lies and feeds, will answer well; and

This was estimated as at least six stones less than it should have been, and deticiency in receipt on hile and beef was put at $50 \mathrm{~s}$. to $60 \mathrm{~s}$., to which has to be alded cost of food spent to no purpose. 
lasd or rancid butter, mixed with a little sulphur, has also been found to answer. Tar answers if earefully placed, so as to be absolutely on the hole into the Warble. Bought cattle are often badly infested, and need attention.

To prevent Fly attack in summer, train-oil rubbed along the spine, and a little on the loins and ribs, has been found useful; so has the following mixture:$4 \mathrm{oz}$. flowers of sulphur, 1 gill spirits of tar, 1 quart train-oil; to be mixed well together, and applied once a-week along each side of the spine of the animal. With both the above applications it has been observed that the cattle so dresscd were allowed to graze in peace, without being started off at the tearing gallop so ruinous to flesh, milk, and, in the case of cows in calf, to produce.

A mixture of spirit of tar, linseed oil, sulphur, and canbolic acid, has also been found useful; and anything of a tarry nature is useful, as sheep-salve (or bad butter and tar mixed with sulphur), or Stocliholm or green tar, rubber on the top of the cows' backis betreen the top of the shoulder-blade and loins. Washes of a strong pickling brine, applied two or three times during the season, are very useful. Paraffin and kerosine are useful for a time, but the smell goes off' hefore very long.

Where cattle are suffering badly from Trarbles, so that the bealth is clearly affected, and the animal wasting, the use of the old well-known "black oils" has been found to do much good.

Mr. Hy. Thompson, M.R.C.T.S., of Aspatria, Cumberland, gires the following recipe used for a bad case : -."Turpentine, $1 \frac{1}{2}$ oz.; sulphuric acid, 1 draclum (here a chemical action sets in and must be done with caution). 'To this I added $10 \mathrm{oz}$. raw linseed oil, and rubber the cow's back once a-day with the mixture. ... In a fortnight the back was cleaned, and all the maggots destroyed."

There are many other points that bear on preven- 
tion, of which one is-noting that Warble Flies are most active in heat and sunshine, and appear not to pursue cattle over water; consequently, allowing the cattle the power of sheltering themselves, and access to shallow pools, is desirable. Liliewise with regard to pastures, or standing-ground of infested cattle, it is matter of course that where the maggots have fallen from their backs the Flies will shortly appear to start new attacks.
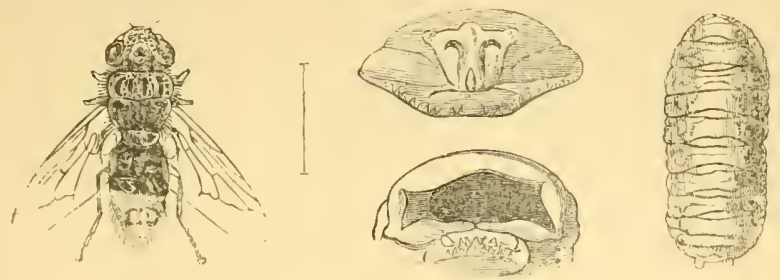

FIG. 60.-Sheep's Nostril Fly: Fly, magnified (with line showing natural length), and maggots. Also mouth-hooks of maggot, and tail segment showing spiracles, magnified (after Brauer).

The attack of the Sheep Bot Fly (the CEstrus [C'phalemyia] Oris) is a very serious matter, which canses much suffering to the animals, and loss to their owners. This Fly is rather larger than the common house Fly, and of an ashy colour, spotted witl black between the wings, the abdomen spottert with black and silvery or yellowish white. The fomale either lays her cegs, or deposits living maggots on the margins of the nostrils of the sheep, from whence the maggots crawl up the nostrils by means of the monthhooks with which they are furnished, and attach themselves to the membranes of the carities. Here they feed on the mucus; and it is stated that they at times feed on the membrane itself. Their presence causes great irritation; and where the attack is severe leads to gradual loss of strength, and convulsions (and other symptoms by which the canse of the ilness is distinguishable, which we need not enter on now), and 
the death of the animal. When full grown the maggots are about an inch in length, and in the common course of things they remain in the head of the sheep for ten months to a year before they are mature. They then leave the animal, by going down the nostrils, and fall to the ground, where they turneither amongst roots of grass, or in any convenient place above or below the surface-to a black or brown pupa, from which the Fly comes out in about six or eight weeks, or after a variable number of days, according to the climate.

The preventive in this case is to keep the Fly from getting access to the nose of the sheep. The sheep protect themselves to the best of their power by holding their nostrils down to the ground, or in any other position which will keep off the Fly, when they are aware of attack; and this principle is worked on, in the application of tar or other remedies to keep the Fly from settling.

In American practice it is said "a practical means of prevention consists in smearing the noses with a mixture of equal parts of tar and grease, or of tar and fish oil, or of tar and whale-oil." . . . "Fish or whale-oil alone is also recommended." The following ointment is also mentioned:- " Bees-wax, one pound; linseed oil, one pint; carbolic acid, four ounces. Melt the wax and oil together, adding two ounces of common rosin to give body, then as it is cooling stir in the carbolic acid. This should be rubbed over the face and nose once in two or three days during July and August." **

T'he attack of Sheep Nostril Maggot is of quite a different nature from that of the Caenurus cerebralis, or Hydatid, which in its young state causes the disease known as staggers or "gid" in sheep); but the

* The above practical recipes are taken from 'Animal Parasites of S'licep' (by Dr. Cooper Curtice), U. S. Dept. of Agriculture, Bureau of Inimal Industry. For deseription of methoil of attack, partly from my own observations, sec my 'Eleventh Report on Injurious Inseets.' 
two attacks are popularly confused. The difference is easily shown by an anatomical demonstration of the maggots in the nostrils in one case, and the hydatidinfested brain in the other.

There is another small division of Flies which infest horses, sheep and other animals, also birds, which are remarkable for their peculiar method of increase. They do not lay eggs, but feed in maggot state on secretions within the abdomen of the female Fly until they are full grown. Then they change to the pupal state, and are produced either in this condition, or quite immediately on the point of changing to it, whence this division of Flies takes the name of pupipara.

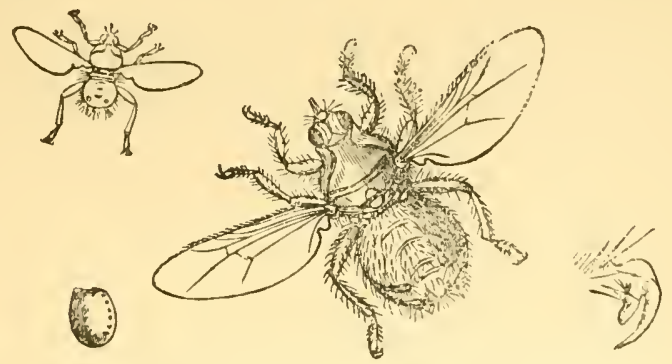

FIG. 61.-Forest Fly, nat. size and magnified. Egg-like pupa and toothed claw, also magnified.

The Forest Fly (Hippobosca equina), which infests horses and cattle, and is especially common in the New Forest in Hampshire, may be taken as a type of the division. The figure above shows the egg-like pupa, and also the peculiar toother claw. The main colours of the little Fly are brown or black, varied with some shade of yellow. It causes irritation both by blood-sucking, and by creeping, which it can do backwards, forwards, or sideways with great nimbleness, on the parts of the animal especially preferred for infestation. 
The remedies used are local applications obnoxious to the Fly, and careful attention to cleanliness.

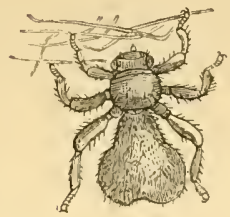

Fia. 62.-Sheep-tick, magnified.

In some cases the head of these Flies (pupipara) is so withdrawn into the body, and the horns into the liead, that, in addition to their sometimes being without wings or poisers, they have a spider-like appearance, and are known as Spider Flies. The Melophagus ovinus, known, though incorrectly, as the "Sheep-tick," which lives in the wool and sucks the blood of the sheep, is one of this division.

Those who wish to study its life-history and means of prevention will find the information excellently given in Dr. Cooper Curtice's 'Animal Parasites of Sheep' before referred to.

\section{FLEAS.}

The Aphaniptera, or Fleas, have been scientifically described as "Dipter" (that is, two-minged Flies), "with laterally compressed body, and distinctly separated thoracic rings." Whether this is precisely so or not is perhaps not very important in the present considerations.

The general appearance of our common Flea is well known; but if examined under a magnifying-glass it will be seen that there are some peculiar points in its structure. The insect is not noticeably divided like most others, but formed of a series of rings from the liead to the tip of the tail. It is to all practical purposes wingless, but at the base of the $2 \mathrm{nd}$ and $3 \mathrm{rd}$ segments firom the liead there is on each side a small scale. These two pairs of scales are considered to represent the two pairs of wings that most insects 
possess, but as they are hardly perceptibie the order has from them been named Aphaniptera (" imperceptible-winged"). The legs look as if they had two extra joints above the thigh. The one that joins to the thigh is a much enlarged form of the hip-joint, or coxa, which hardly shows in the legs of many insects, and therefore is a good anatomical example; and
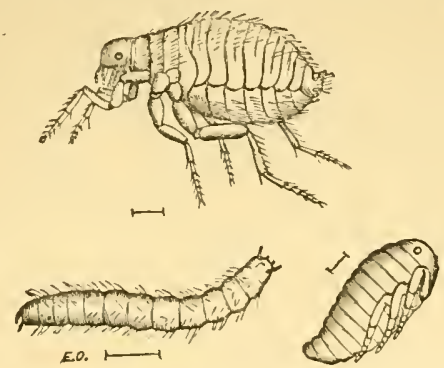

Fig. 63.-Fiea: máoso on, and pupa, magnified.

above it, joining the coxa, or hip, to the body, is a prolonged growth from the lower part of it, giving the appearance of the leg being formed of five joints.

Fleas lay about ten or twenty eggs in hair of animals, or dusty nooks or crannies, \&c., especially where infested animals lie. From these eggs, white, wormlike, footless grubs hatch, which feed on animal matter, and notably on blood. In summer they change their condition in about a fortnight, and, after casting their skin, appear as chrysalids, resembling the perfect Flea, but inactive, and with the legs folded beneath it. From these the Fleas are said to appear in rather more or less than fourteen days.

As a farm pest, I can say from personal observation that these most umpleasant creatures sometimes swarm in legions in neglected yards, where they may be seen by scores skipping in all directions about the haunts where nothing but dirt and neglect have allowed them to be reared, although hheir presence will very 
likely be stated to be "quite unaccountable." Order and cleanliness, proper clearing out of old skins and rubbish, scalding out dog-kennels and slaughter-houses, and all other head-quarters of filth, and letting brooms, scrapers, and whitewash do their work in poultry-sheds, and all other places, will promptly reduce the armies.

\section{CHAPTER V.}

BEETLES (COLEOPTERA).

Cockchafens, Clitck Beetues, \&c.
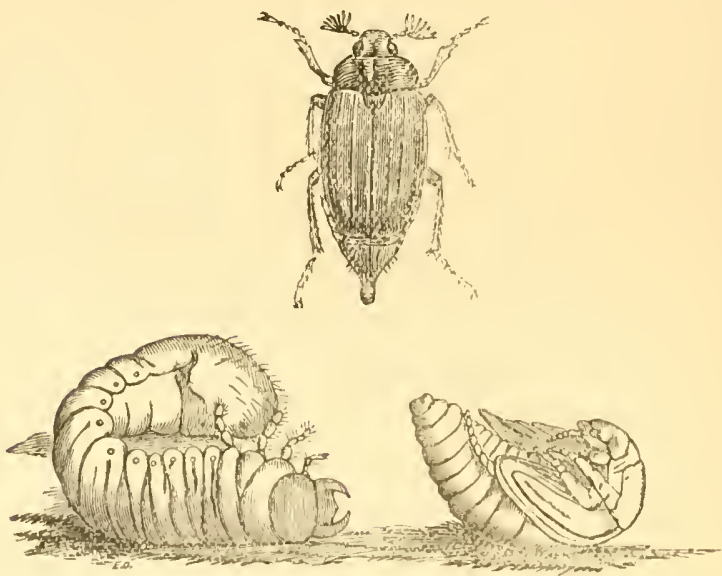

FiG. 6.1.-Common Cockchafer, magrot, and pupa.

We now pass on to the order of Beetles (Colcoptera). From the fact of there being a very large number of 
different kinds, and also from a great number of these injuring the crop, both in the grub, and in the Beetle state, this order is, perhaps, the most important of all to the farmer.

It will be noticed that, so far as we have advanced, there is just, so to say, a step onwards in the number of legs and wings in each order. Flies have usually one pair of wings, and their maggots are usually legless. Fleas have also legless maggots, but in the perfect insect the position of two pairs of wings is marked by scales. In the Beetles we find that the maggots or grubs are sometimes legless, but also sometimes have three pairs of jointed legs,-one pair on each of the three segments nearest the head, and also a sucker-foot beneath the tail, which serves to help in moving, or to hold fast with when pulled at.

Beetles, as a rule, have two pairs of wings (see Fig. 74, p. 89). The upper pair, or wing-cases, which are known as the elytra, are hard and horny, and form a cover or "sheath" for the lower pair ; and from this the order of Beetles takes its name of Coleoptera, or sheath-winged. The under wings are membranous and large when spread out in flight; when at rest they are folded both lengthwise and across, so as to fit under the wing-cases. Sometimes the under wings are absent, which is a very important consideration in preventive measures. The jaws are horizontal, somewhat like toothed pincers laid flat, so as to work against each other from side to side.

The Beetle chrysalis is much like the perfect Beetle in shape, but without power of moving about. It lies with the forming limbs, and mouth parts, beneath it, usually all cased in separate sheaths, like a thin outer skin, until it is matured, when it gradually frees its limbs, and gains its full colour and powers.*

Though there are such great numbers of different kinds of Beetles, the distinctions between the chief

* For figures of Beetles in their larval, pupal and complete condilions, see the illustrations in this and the following Chapter. 
divisions are fairly easy to observe; and I will just point out a very few of these that may be of service before going on to the practical observations.

Beetles are, or may be, firstly, divided into four sets, according to the number of joints in their feet:-

One division has all the feet usually five-jointed. This includes six sections, of which those of the carnivorous Beetles, the Cockchafers and their allies, and the Click Beetles (or Wireworm Beetles) and their allies, concern us the most. This division is named Pentamera.

The second dirision has, for the most part, the feet of the two front pairs of legs five-jointed, and the feet of the hind pair four-jointed. This division has only one section, in which various grain and meal Beetles concern us most. This division is named Heteromera.

The third dirision has all the feet apparently fourjointed, because the fourth of the five joints is so small

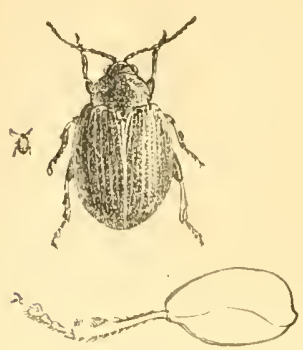

Fig. 65.-Ho\}) l'lea Beetle, and f mm-jointed loot. it can hardly be seen without a magnifier. This division, Tetramera, or Pseudo-tetramera, includes three sections, all very important to us. They are the Weevils ; the Long-horned Beetles, which are often destructive to timber ; and the Turnip Flea Beetles and their allies. The illustration shows the leg of one of the Flea Beetles with its fourjointed foot.

The fourth division has all the fect apparently three-jointed, because the third of the four joints is so small it is scarcely visible. This division, Trimera, or Pseudotrimera, induites me section, and in it the family of Ladybird wnd th ir allies is most important to us.

These a is (1) \& by number of joints may seem tedious, o truit points to observe; nevertheless it is very con un, when one wishes to linow some- 
thing of the nature of a Beetle, to be able, merely by a glance at its feet through a hand-magnifier, to know generally to which division it belongs. Amongst the thousands of British Beetles, there are many so very like in appearance, yet different in habits, that sometimes it saves much trouble, thus by a little examination to lnow whether what we have canght is a destroyer of crop pests or crops in the field, or of stored crops in our granaries.

The Gcodephaga, or Ground Beetles, which belong to the first section of the Beetles, are, in great part, carnivorous. These Beetles may be known, in a general way, by their long slender legs and horns, their strong jaws, and their great activity in running.

The grubs of these " Ground Beetles" are usually flat, long, and straight-sided; the head, and next segment to it, lard (see figure, p. 17). They have, for the most part, strong jaws, three pairs of horny legs; and at the tip of the tail there is usually a sucker-foot below, and two horny or fleshy appendages above.

For a long time these "Ground

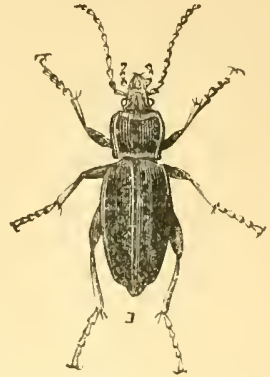

Fig. (f6.-A Ground Beetle (Carabus gramulatus).

Beetles" were supposed to live almost entirely on animal food, and therefore to help very much in keeping other insects in check; but now it is found that various kinds injure growing grain, seeds of grass, and other vegetables.

In the United States it has been found, by watching the habits and examining the contents of different linds of ilarpalus, that these feed on rootlets, seeds, and other parts of grass or corn, besides other matters animal and vegetable. In Prof. Forbes' experiments it was found that of twenty-eight specimens of Carabide examined, twenty specimens, and these belonging to eleven species, had eaten vegetable food. 
This has not been worked out fully in England, but. Curtis drew attention to the subject many years ago, and pointed out that the Zabrus gibbus (figured, p. 17) was very injurious as a kind of Ground Beetle which injured the Wheat; also he expressed doubts whether Harpalus grubs did not injure Wheat also in the same way as Wireworm.

So far as I am aware, no further observations were recorded on the subject until about the end of the.

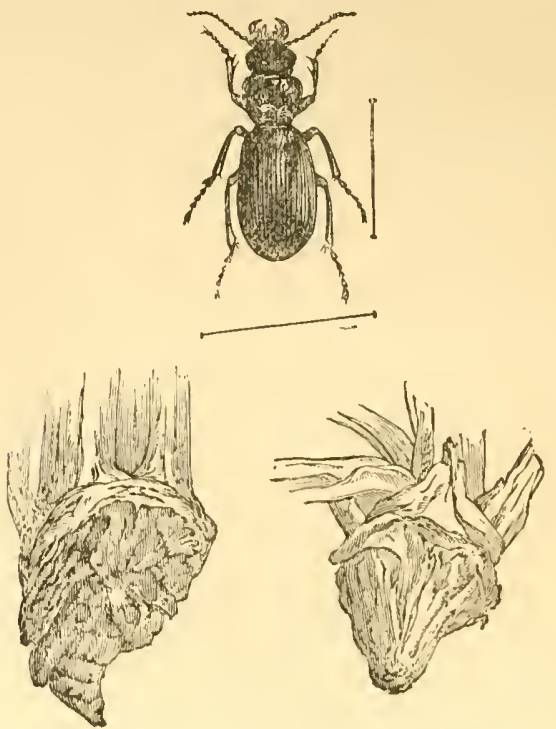

FIG. 67.-Mangold-fceding Ground Beetle (S. madidus), and gnawed Nangold roots.

winter and early spring in the year 18s8, when specimens of a grub, minutely resembling that of this species of Corn Ground Beetle, were forwarded to me as doing much mischief to young Wheat plants in various parts of the south and east of England. (For figure of $/ /$. gibbus, see p. 17).

In the summer of 1885 the night-feeding Ground 
Beetle, Steropus madidus, was sent me from near Bishop's Stortford, Herts, where specimens were captured in the act of feeding on Mangold roots. Fig. 67, p. 84, shows the Beetle magnified, and also the method in which the Mangold root was torn away by its powerful jaws. These Beetles are partially carnivorous, as one of those forwarded to me lilled one of its companions, and consumed its contents; but their field work, being abont three 'in the morning, is seldom noticed.

These observations make it very desirable to keep an eye to the habits of the many kinds of these pitchy or brownish "Ground" Beetles that we see so active in summer in corn-fields, and which have generally been supposed to be employed in clearing off insect vermin.

The water kinds (Hydradephaga) can swim as well as fly. Their somewhat flattened oval shape, and their hinder legs, being for the most part broad, with a long fringe of hair's on the inside, give them the power of rowing quickly through the water; and the large

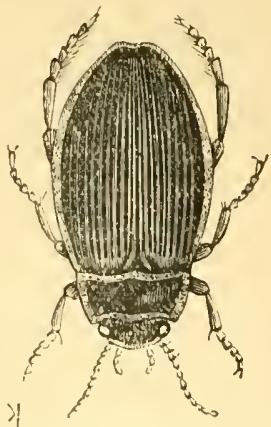

FIG. 68.-Water Beetle. wings, folded under the cases, give them the power of going to and from it as they wish.

The second section, the Brachelytra, commonly called Rove Beetles, may be generally known by the short wing-cases, and, in the case of the very common Beetles, sometimes known as Devil's Coach Horses, of which Fig. 69 represents one species, by their habit of arching up their tails when annoyed. Some feed on animal matter, including other living insects, and they much frequent rotten animal and vegetable matter. The grubs are very like those above described, but may be known by the fork above the tail being double-jointed, 
and furnished with stiff hairs. Both grubs and insects help us in clearing off other insect presence.

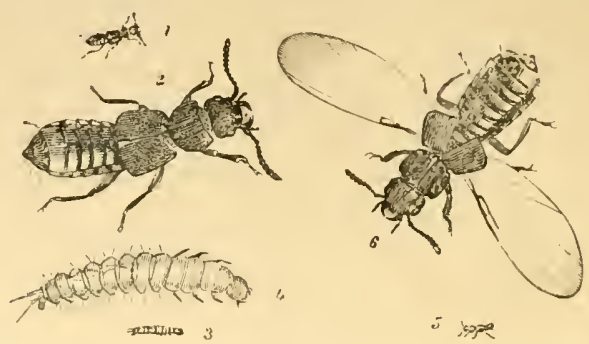

FrG. 69.-Sculptured Rove Beetle and grub; nat. size and mag.

The third section is that of the Necrophaga, or Clavicornes, which includes Beetles of very various habits,

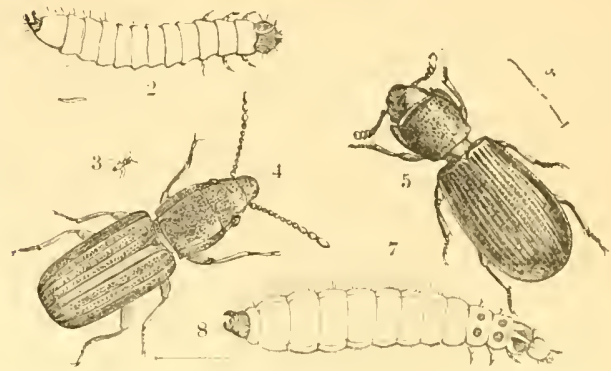

Fig, 70.-Corn Curujus and cadelle: 22-1, Cucujus testaceus; 5-8, Trogositu munritunicu; magnified, with nat. size.

but for the most part feeding on decayed matter (especially the division often known as Sexton Bectles, which live for the most part in dead animals, carrion, and what we may shortly describe as "filth" generally). Their horns are usually enlarged or clubshaped towards the tip, or bent as if they had an 
elbow; and the wing-cases usually bend down at the sides, so as to cover the sides of the abdomen.

Some, like the Cadelle, and Corn

Cucujus (Fig. 70), are Corn feeders, and various kinds frequent flowers. Of these some species of Meligethes, or Turnip Flower Beetles, are very injurious, and furnish one of the few examples of infestations which may be satisfactorily lessened when established on the plant by remedial measures. The little green Meligethes Beetles may sometimes be found on the flowering shoots of Rape,

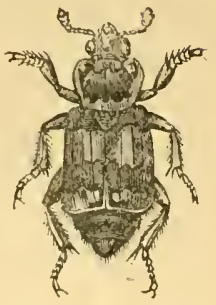

Fig. 71.-Sexton Beetle, magnified.

Cabbage, and Turnip, and cause great loss where the crops are being grown for seed.

The Beetles feed on the pollen in the flowers, and lay their eggs in the unopened blossoms; the maggots

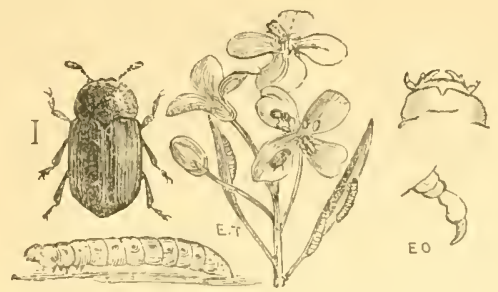

Frg. 72.-Meligethes anens: Beetle and maggot, magnifier, and infested flower, after Dr. 'Taschenberg.

from these feed in the bud and base of the flower, the stalks of the flowers, and the seed pods. As a remerly it is found to answer well to liave the infested tops and early blooms of the Turnips piekerl, and put, with the Beetles and maggots, into bags which are tied up as soon as full, and the contents destroyed. Under this treatment the growth of flowering shoots is much thickened, a great deal of the infestation is got rid of, and the crop is thrown back about a fortuight, 
which gives the rootlets increased time for action, and the plan is considered certainly beneficial in insrease of crop, independently of clearing the insects.

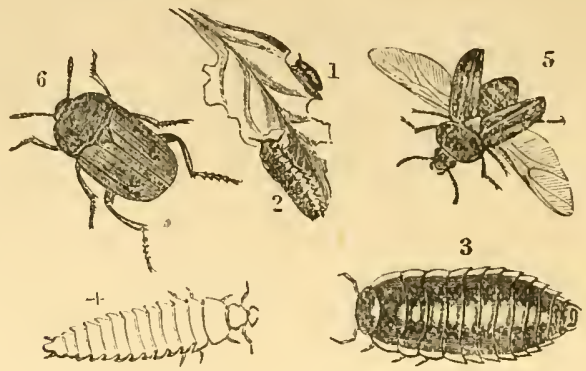

FIG. 73.-Beet-Carrion Teetle: 5 and 6, Beetles; 1-4, larva, nat. size and magnified.

In the Beet-Carrion Beetle, which takes its double name from its donble habit of feeding, we have again an example of the mischief which is, or nay be, often caused to a crop by bringing out manure in which there is a two-fold kind of feeder.

The egg of this Beetle is commonly laid in putrid matter, such as dead birds, hedgehogs, or the like; but sometimes the grubs attack Beet or Mangold Wurzel leaves in such great number's as to clear off all but the fibres, and thus ruin the crop. In some cases noted it appear's likely that oftal, or carrion, may have been mixed with the manure, and thus attracted the Beetle, and the eggs, or grubs, were carried out in the rotting substances. Thongh the attack is not common, when it occurs it is bad, and, unless care is taken, is apt to recur for some years, though possibly proper treatment of the manure would prevent recurrence. As this attack on!y lists for a fow weeks (the grulls are full-fed abont the end of June), the erop may often be saved by timely rlressings of superphosphate, or some good fertilizer. 'l'he ligure shows the Beetle and two slightly different shapes of grub. 
The fourth section is the very important one of the Lamellicornes, or Chafers. Some of these do us little liarm, like the Stag Beetles, of which the grubs, so far as I am aware, live in rotten wood; or, again, the

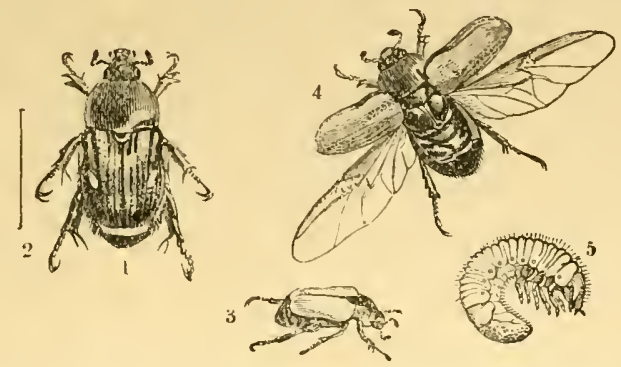

FIG. 74.-Field or Garden Chafers : 1 and 2, Anisoplia agricola;

3 , A. horticola, nat. size; 4 and 5 , the same, and grub, mag.

Click or Dor Beetles (Geotrupida), which bore down into the ground, especially where droppings are lying

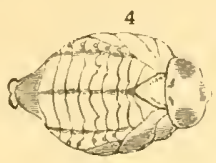

3

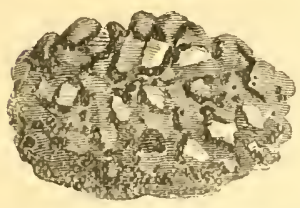

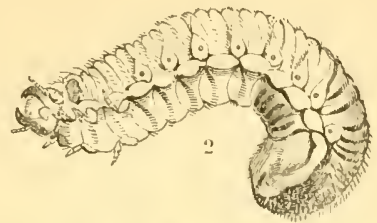

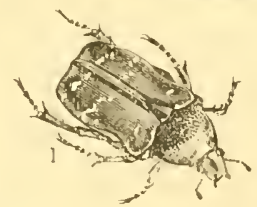

Fig. 75.-Golden Chafer': Beetle, grub, back of pupa, and earth cocoon.

in cattle pastures, and carry the dung into the soil as food for their grubs. But there are many kinds, such as the Small May-bug or Garden Chafer (Anisoplia 
horticola), 3, 4, 5, Fig. 74 (of which the grub does much harm in pasture land), together with another much rarer kind, the A. agricola; also the Common Cockchafer, the Great Golden Chafer, and others which, in this country, feed, in the beetle state, on leaves of trees, or within flowers, and as grubs on the roots of grass, corn, or other ground crops, as well as trees; and, in the colonies, on the roots of Coffee and Sugareane, and altogether cause most serious loss.

The Beetles are generally to be known by having a club of several leaves on their horns, such as the fanlike end that we see to the horn of the Cockchafer; and

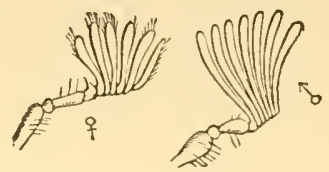

Fir. 76.-Club of male, with seven leaves; club of female, with six leaves, magnified.

the grubs are large (sometimes as thick as the finger) and fleshy, with the end of the tail curved downwards and enlarged, as if it was swollen, so that the grub usually lies on its side. By this swollen tail and arched shape, and also by having three pairs of longish legs and strong jaws, you may commonly know the Chafer grubs. (See Fig. 6, p. 7.)

The habits of different linds of Chafers vary in such matters, as the depth to which the grubs bury themselves, or at which they turn to chrysalids, the length of time they pass in these two states, and also the time of day, or evening, when the Beetles are at rest, which is a very important point in regard to getting rid of them; but the life-history of the Common Coclichafer gives a good general idea of that of the linds that we are most troubled by. (For figure in three stages, see p. 80.)

These Beetles apperr in early summer, and feed on leafage of many linds of trees. The females lay their 
eggs in ground which is either cracked, or will allow of the female burrowing down into it to lay (the state and kind of ground is an important matter); she lays from twelve to as many as thirty eggs, from about four to eight inches deep. The grubs from these hatch in a few weeks, and feed on roots; may be devastating young Fir plantations, or attacking Flax, or Carrots, or many other crops, or ruining grass fields; there is a surprising variety in the kind of crop infested. After feeding for three or four years, they go as much as two feet or more down into the ground to turn to chrysalids, from which the Beetles come up in the following summer, that is, the fourth (or, according to other opinions, the fifth) summer after they were hatched.

Many of the Chafers only fly at some special time in the day, and rest during the other hours in the leafage of trees. The only way that appears known to get rid of the Beetles is to profit by this habit. Find what trees they frequent, and at what time they are resting, and then beat them down. They may be beaten down on cloths, and gathered up in any convenient way and destroyed; but it is a simpler plan to have a drove of pigs in waiting, which will destroy the Chafers before they can be ready to fly away. This plan of beating is found to answer both in European and colonial practice, as it stops present damage to the leafage, and coming increase from eggs that would be laid.

One great point is to keep the female from going doun into the ground to lay her eggs. Sometimes, where the soil is of soft vegetable remains (as amongst the Coffee plantations in Ceylon), it is found that laying a coat of the clay subsoil on the top answers; and, for field treatment, it lias been advised to lay a good covering of some hariter material, as marl, or road-scrapings, on the surface, or to give a top-dressing of salt or gas-lime, or some application which might make the surface unsuitable for laying. Probably gas-lime would be very serviceable, and the washings 
down from this would be likely to drive any grubs near the surface away, for a time at least, and thus give the crop a respite. Gas-water applied at a strength which would not hurt the grass has been found to act well; the strength, of course, must be found by trial, as this varies much.

The attack of the grubs to roots of growing crops, whether in the field or of plantation trees, is very difficult to meet. In plantations the only"sure way appear's to be the plan practised in Ceylon, of setting people to dig up the grubs with stout wooden pegs, or any other convenient implement. In this case the ground should not be disturbed before the worker, but just sprinkled with lime. The operator then goes regularly forward, clearing to the depth at which the grubs lie, and stirring the lime into the soil; and the plan is found to answer both in benefit to the trees and in getting rid of the grub.

With such kinds as the Sugar-cane Chafer (Pentodon fossator) of Trinidad, which turn to chrysalids just below the surface of the ground, the plan of turning them out of their earth-cells by any common agricultural measure answers perfectly, at small cost; and where grubs are in unoccupied ground, that is, after the grass or erop has been killed or gathered, a great many may be got rid of by ploughing or digging deep enongh to turn them up, and calling in the help of children to collect and destroy them, or that of the pigs, which will do much work without pay. 'The wild birds also, such as sea-gulls and rooks, should on no account be livien away.

'There is, however, another treatment, not nearly enough thought of, which is applicable to all cases of infested land free of crop, and that is putting on a heary lilling dressing. Caustic gas-lime may thus be used, and alkali waste is excellent for the purpose. These are very much alike in their nature and effects; at first they destroy everything they touch, whether plant or insect, and the alkali waste is also used to 
clean the ground of deep-rooted weeds, such as Couchgrass, Coltsfoot, and Thistles, and is washed down by rain into the soil so as to make the drains run milky at a depth of three feet. This is procurable for little if any outlay beyond cost of carriage from chemical works, where it is thrown ont as waste. Now attention has been drawn to its value, and it is likely to be made available. When it (or the gas-lime) has done its first work in the caustic state, the action of the air gradually turns the poisonous properties to sulphate of lime, and they become a good manure of the nature of gypsum.

If a heavy dressing of this kind was spread on land infested by any grub at the time when it is near the surface, and without disturbing the land, we should thus take it, as it were, unawares, and it would be destroyed by the poison before it had time to get out of the way, instead of, as is often the case, being merely made to go down to a safe depth, from which it presently comes up again to attack the new crop.

Tho return to the Chafers. This is one of the classes of attacks which we can at present only hope to meet by special observations, in cases where as yet the histories have not been recorded. Where do the Beetles feed; what kind of soil do they frequent; are they attracted by farm manure? This is a very important point, for the grubs of one or more kinds will leave preying on roots to feed in manure, and it is possible this may attract the Chafer's for egg-laying. All these points and many more are what we need to know; and in the next division of injurious Crop Beetles it will be shown that equally hurtful attacks are put quite in our power by a good practical knowlerlge of these points.

The fifth section of Beetles belonging to the great division of the Pentamera, or those haring customarily five joints to their feet (tar'si), is that of Ship-jacks and their. allies, scientifically the Sternoxi. These do little if any harm in the beetle state, but in the grub-state-that is, as what we know as Wireworms-the mischief 
and loss they cause to the country are beyond calculation.

The Wireworms will feed on the roots of almost all farm crops excepting Mustard, which they frequently have been found to avoid, and live for fire years before

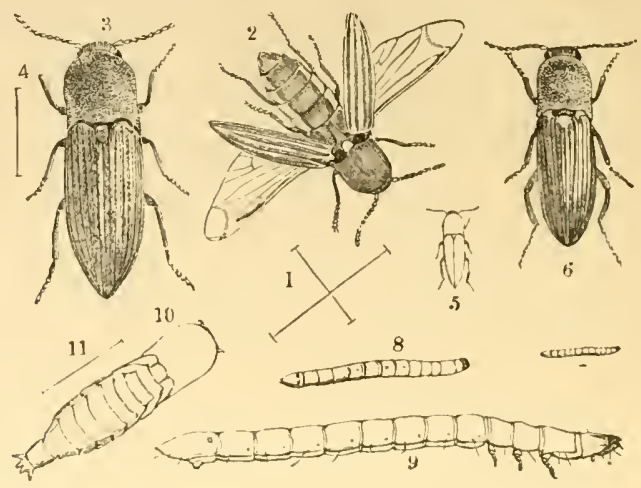

Fig. 77.-Click Beetles and Wireworms: 1 and 2, Elater lineatus; 3 and $4, E$.obscurus; 5 and $6, E$. sputator, nat. size and magnified; 7, Wireworm of E. sputator? 8 and 9 , Wireworm of E. lineatus, nat. size and magnified; 10, back of pupa of Wireworm. Lines show nat. length.

they cease eating to turn to chrysalids, and thence to Click Beetles. They are of the shape figured, and commonly of a yellowish colour, and talie their name from their great likeness to a short thick piece of flattened wire. The Click Beetles are of many linds (see above figure), commonly about a quarter to half an inch long, and about a third of that in breadth (of the shape figured), and of a brownish colour, though sometimes of a beautiful red, and take their name from their power of regaining their position when laid on their backs by a sudden jerk or skip up in the air, accompanied by a click.

The female Beetle lays her eggs on, or a little below the surface of the ground, amongst leafage or roots, 
and especially in such places as grass meadows, or clover leys, where the surface is undisturbed for a time, possibly for years, and consequently the ground below swarms with Wireworms of all ages. When the pastures are broken up, these tough-skinned grubs are in no way hurt, but remain in the ground, ready to feed on each succeeding crop that is put in, until the time for their change comes.

Clover leys and pastures are the main starting-point of Wireworm-attack to our field crops, and the method of treatment may be considered under the two heads: firstly, how to prevent egg-laying, and clear infested land, before re-cropping or sowing; secondly, how to lessen ravage, or support the plant under it, if Wireworn is found present in the growing crop.

To prevent egg-laying the ground should be made as unsuitable as it can be for the purpose. It is advised to feed down the grass as bare as possible before ploughing, or to go further, and pen sheep on it, gradually moving the hurdles forward, so that every part of the field may be thoroughly trodden. The sheep in this case are fed with Turnips and other regular feeding stufts, and the amount of liquid and other manure thus worked into the land, thoroughly prevents the field being inviting for eggs to be laid on it, and destroys any eggs that might be on the surface. Dressing pasture-land with lime brought fresh from the kiln, and spread hot so as to burn the grass, answers well. Sowing salt, at the rate of 5 to 8 cwt. per acre, on grass or ley before breaking up has also been found to answer, and good dressings of caustic gas-lime, or of alkali waste strong enough to destroy all live matter on the surface, are very serviceable. Paring the surface, and collecting and burning the parings, gets rid of a deal of Wireworm, if the burning is done whilst the Wireworm is in it; and in any case gathering up the surface rubbish, and burning it, is useful as a preventive, for, even if the Wireworm lins left the locks of roots for a time, we thus get rid of the 
knotted lumps to which it would have presently returned, and which would have kept the land open for its passage.

The habit of the Wireworm in feeding is to keep near the surface, gliding about, as its smooth glassy surface enables it to do, from one plant to another, eating out a piece here and a piece there, and thus injuring the whole crop; and, if this happens whilst the crop is in its first growth, the value even of those plants that struggle through is much lessened. For this reason the main points, in preparation of ground to carry the plant over attack, consist in treatment that will give a good seed-bed, and mixing the soil with such chemical manures as will be good for the plant and unsatisfactory at least to the Wireworm ; also so to clear the ground of rubbish and work it that it may be sufficiently firm (or admit of being sufficiently " firmed" by treatment afterwards) to prevent the travelling of the Wireworm. For this purpose it is advised to plough in good time in autumn, and work the land well so as to get it in good order and consolidated, and either by burning, rotting, or whatever means may be preferred, prevent it being lept open and full of harbours for Wirearorms; stubble and roots, cabbage stalks or bcan haulm, and all such matters, are Wireworm-helpers. If we look down the notes of special applications found serviceable to plough in, we see constantly repeated :- sait ; salt ; salt ; gas-lime; gas-lime; lot lime; lime and salt; and in a less degree (probably because it is not so well known) alkali waste is also highly recommended. Kainite also is useful, and regular fertilisers, as superphosphate and also nitrate of soda.* But it is worth

* The xeader is requested to observe that $I$ am in no sort of way advising growing crops, especially Turnips, without a liberal supply of farm manure, but merely, as ny business in the matter is to pont out where special pests harbour, I just notice that several of themWireworm amongst others-are sometimes found in stable, cow-slied, and other animal manure, anil that consequently examination of its condition, and, if found to be infested, due means of remedy, are desirable. 
notice, especially in preparation of ground for Turnips, that there is a great doubt whether Wireworm is not often encouraged by the use of farm manure. The Wireworms of two of the commonest kinds of Click Beetle have been found respectively in dung, and in well-rotted horse-dung. It is considered by some farmers that crops so manured are the most infested, and if we consider that in this manure a large portion of the material is still unchanged vegetable matter, of much the same kind as the Wireworms wonld naturally feed on, it gives a reason for attention to this point. Thorough salting of farm manure has been advised to get over this difficulty. It should also be remembered, that heaps of decayed turf are headquarters of Wireworm, unless treated with caustic lime, salt, or the like dressings; also that (take what pains we will) if grass headlands or grass strips are left across or by our fields, there we make homes for the Wireworms, and they will add all requisite comfortable provision from our crops.

The only crop which Wireworm appears to have customarily a great objection to is Mustard. This, therefore, is sometimes useful as a cleaning crop.

When Wireworm is present, strong fertiliser's - such as nitrate of soda, guano, superphosphate, or othersare serviceable; and mechanical means, such as heavy rolling, are of use, for thus the creature is prevented travelling, and some of the pests are probably set fast and killed. Treading by sheep, or cattle, or by the heavy iron-shod feet of the horses, similarly firms the soil serviceably.

The Wireworm can be drawn away from the attacked plants by dressings of rape-cake or Indian rape, that is, mustard-cake, and in the latter case has been found by experiment to perish in about a fortnight where it had no other food, and, connecting this with the power of Mustard as a cleaning crop, it suggests further experiment would be useful.

These are some of the main points of Wireworm 
prevention :-Prevent egg-laying; clear the ground of Wireworm, and get a good start for the plant; keep up the strength of the plant under attack, and keep the power of the Wireworm in check; and also do not

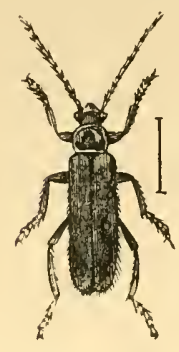

FIG. 78.-Soft dress your land with Wireworm, either in decayed turf or by letting grass homes for it be amongst your erops. The subject is one of great importance.*

The sixth section, having for the most part five-jointed feet, includes the Softwinged Beetles (Malacodermi), such as Glow-worms, and those commonly known as "Soldiers" and "Sailors"; also the Death-watch Beetles, and many other kinds of wood-boring Beetle. Beetles. But, excepting a kind injurious to Raspberry plants (Byturus tomentosus), I am not aware of their attacks being serious to fruit or crops.

In some years, as in 1891, these " Raspberry Beetles" do great harm in Raspberry plantations. They come out in the spring and attack the buds and blossoms, but this is not all. The maggots which hatch from the eggs laid by the female Beetle beside the young forming fruit, feed within it till it and they reach maturity, and thus cause a second series of losses. When mature they leave the fruit, and turn to pupal state in cocoons under Raspberry bark, or some shelter about the bushes, from which the yellowish downy Beetles come out in spring. The most satisfactory remedy appears to be shaking the infested shoots over bags soaked in paraffin oil.

Some of the Beetles of this section of Malacoderms feed, in beetle or larval state, on living insects: some on bones, dry skins or carcases; some in standing or

* Full notes by good agriculturists are to be found in the 'Journal of the Royal Agricultural Society,' part I., for 1883, and also in my ' Report on Wireworm in Observations of Injurious Insee . for 1882,' jublished in 1883. 
manufactured timber, as furniture, or rafters, where they do boundless mischief.

Amongst these the presence of the so-called Deathwatch, the Anobium tessellatum, may be easily detected
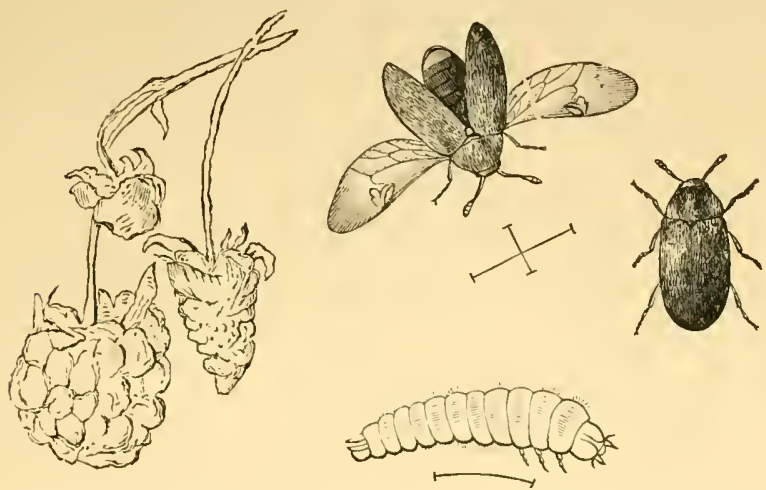

FIG. 79.-Byturus tomentosus, "Raspberry Beetles," much magnified, with line showing nat. length; maggot, magnified, with line showing nat. length, after sketch by Prof. Westwood. Raspberry Iruit.

by the dust thrown out from their little round shothole-like burrows in chairs or tables, and may be as easily cured or prevented by plentiful use of oil and turpentine.

The Xyleborus (or Bostrichus) dispar, more conveniently known as the "Shot-borer" Beetle, is noticeable for its rapid power of destruction of living trees. The very small dark brown Beetles drive their tunnels so as, in the case of quite young trees, partially to ring them, and to clear out an inch or so of the central pith, besides running other galleries, so that the tree perishes with a rapidity quite unaccountable until the presence of the infestation is found out. The Beetles are remarkable for their "disparity" of size and shape, whence the specific name. The female is about the eighth of an inch long, with the thorax (or fore body) large in 
proportion, and raised in the middle so as to form a kind of hump ; the male is only about two-thirds the length of the female, and wider in proportion, and
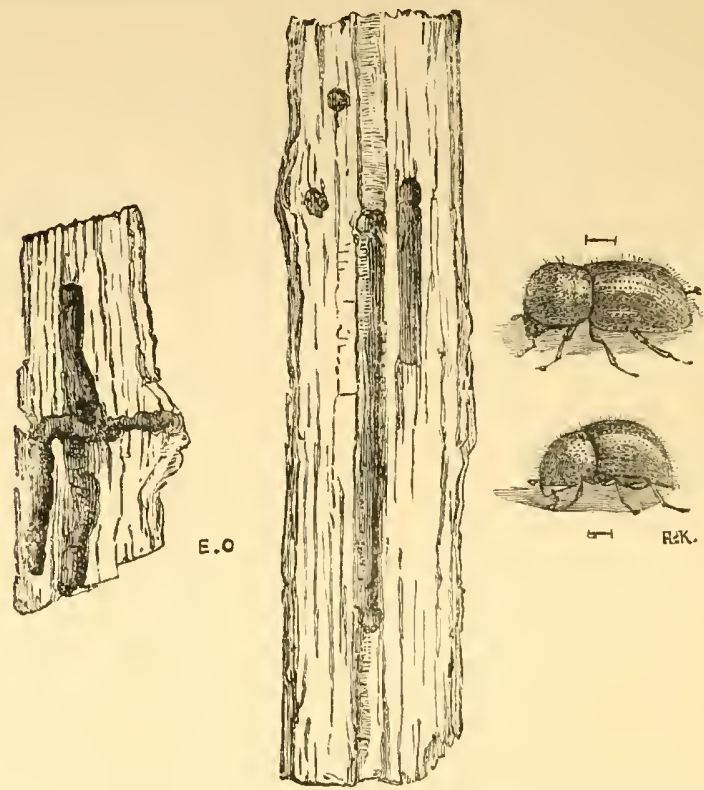

Fig. 80.-Xyleborus dispar: Male and female Beetle, magnified; lines showing nat. length. Plum stems, showing horizontal and perpendicular galleries.

flatter. Multiplication takes place in the tunnels bored by the parent Beetles, and in September the borings may be found so crowded with Beetles that there is not room for another specimen.

This is an example of the class of attacks in which the wisest course is to cut down the attacked tree and burn it as soon as the presence of the infestation is observed. It is no waste, for where the tree is to a great extent ringed and the pith clearcd, its death 
rapidly follows. The attack has hitherto been exceedingly rare in this country, but in 1889 did a considerable amount of damage to young Plum trees in two or three localities in the West of England; but by prompt measures the further spread of the pest was prevented.

\section{CHAPTER VI.}

\section{BEETLES (COLEOPTERA). (CONTINUED).}

Weevils, Turnip Flea Beetles, dc.

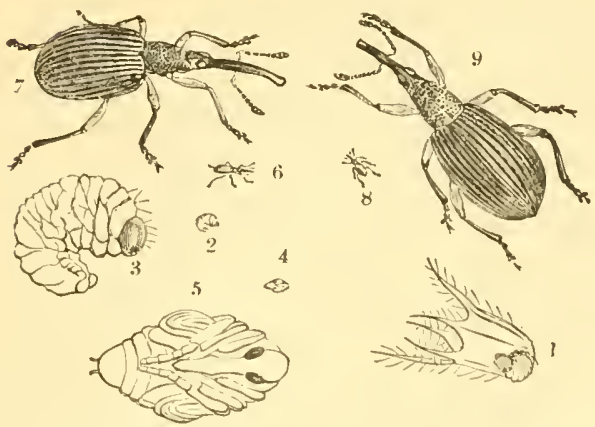

FIG. 81.--Pear-shaped Weevils: 6, 7, Apion apricans ; 2-5, maggot and pupa; 8, 9, A. assimile;-all nat. size and magnified ; 1, maggot feeding, magnified. 
The Weevils and their allies, and the Turnip Flea Beetles and their allies, are what next require especial attention; but a few observations on the other main divisions are necessary so as to give a connected idea of the arrangement of this great order of Beetles to those who may wish to carry the study further.

We have in the preceding Chapter noticed the kinds that most concern us in the first of the four large divisions, namely, those known by having five joints to each foot (Pentamera).

The next division is known by having five joints to the feet of the two front pairs of legs, and four only to the feet of the hinder pair (Heteromera). This includes Beetles of very various shapes and colours. Amongst these are the Tenebrio molitor, the parent of the Mealworm (for reference to figure see list of illustrations) ; the slow-moving black "Cellar" or Cluurchyard Beetle (Blaps), with their wing-cases soldered together; the beautiful and active red Cardinal Beetles (Pyrochroa), and the bright green Blister Beetle, formerly Cantharis, now Lytta versicatoria.

The third division of the order of Beetles, that of the Tetramera or Pseudo-tetramera, which have apparently four joints to their feet (see 8, Fig. 86), is very important agriculturally. It includes the Weevils; the Long-horned Beetles, which mainly frequent timber; and the Turnip Flea Beetles.

Of this division the Rhynchophora, or Weevils, is the first in order. Weevils may generally be known by the head having a proboscis, or snout. This is sometimes short and broad; sometimes curved and narrow, and nearly as long as the whole body; and on the side of this snout the horns are placed. 'These are commonly what is called "elbowed"; that is, the lowest joint is long, and the others are joined to it at an angle. Many of our crop Weevils are small, some only about the twelfth of an inch long, few as long as a common Wasp. 'They are usually very hard, and much rounded at the sides; and though some are 
specially named pear-shaped Weevils, this idea of the shape of a pear would fairly describe the general shape of many of this section. (See Fig. 81.)

The grubs, as far as they are known, are much like the well-known grub of the Nut Weevil. They are white and fleshy, often much wrinkled across, and legless. They are usually a little bent together (like

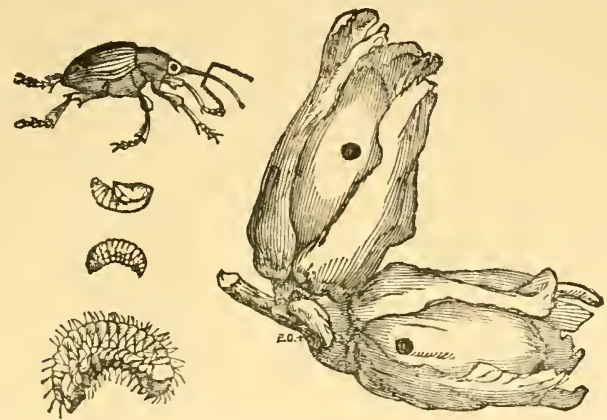

FIG. 82.-Nut Weevil, mag.; maggot, nat. size and mag. ; pupa, nat. size. Filbert pierced by Weevil.

Cockchafer grubs), and have a horny head furnished with jaws. The pupæ are like the Weevils they will turn to, but with the limbs beneath them, and inactive.

The habits of the Weevils differ very much: some of the timber Weevils attack the trees in a completely different way, according to whether they are feeding, or boring for egg-laying; others, such as the Turnip and Cabbage-gall Weevils, cause root-galls by the irritation set on foot by the egg, which they place in the root; but whether the Weevil does much harm or not, the grub is always hurtful, and there are many attacks which have so much in common that they may be classed together to be got under by one kind of remedy.

We may first notice some of the attacks that can be lessened by shaking down the Weevils. 
The Apple-blossom Weevil (Anthonomus pomorum) does much harm by laying its eggs in unopened Applebuds, where the maggot feeds, and thus destroys the young forming fruit. This Weevil shelters itself during winter under clods of earth and rubbish, and also beneath rough bark on the tree (so that keeping rough ground and bark in order serves much to

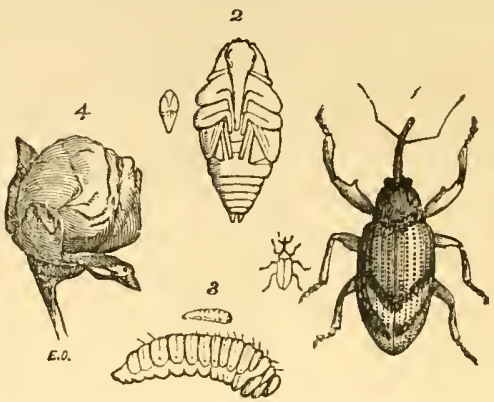

Fic. 83.-Apple-blossom Weevil, maggot and pupa, nat. size and magnified; infested Apple-bud.

diminish their numbers); but further, it comes out in the spring, and the females, it is stated, rarely fly, but crawl on the branches, and drop down on being alarmed.* By working on this habit of the Apple-

* In the life-history of this insect by John Curtis, he says :-" In March, when the flower buds are swelling, the Beetles emerge from their retreats, when the males are seen in sunny mornings flyin amongst the trees in search of the females, who generally are erawling over the branches, although they are also furnished with wings." Also, in the same paper (in the 'Gardener's Chron.' for 1814, p. 556), John Curtis says, "From various statements it seems that the females will not readily fly, and as they crawl up the trees their incursions may be stopped and the erops saved by winding tarred bandages round the npper portion of the trunks." This point of the female Beetle rarely $\mathrm{Hy}$-ing is mentioned also by Schmidberger; but in a series of observations made at one locality in Kent in 18!0, it appeared that females might then be found on the wing. As, however, the observations from which I gave the note of habits in my tirst eaition, and also the beneficial effeets of jarring to throw down the Weevils, stand on such good authority, I think it best to leave the above passage almost unaltered. 
blossom Weevil (and of some other kinds), we may clear many sorts of fruit trees and bush fruit simply by jarring the boughs. Thus the Weevil falls, and we only need to use such plans as common sense will teach us, to keep it from getting back again. With the Apple Weevil, or those that are shaken down from the trees, such methods as putting a rough rope, or a ring of anything they will not cross on the ground, round the trunk, answer well. This may be made of twisted hay (or anything preferred), which has been dipped in spirits of tar, or in tar and coarse oil, so that it may keep wet and sticky; or caustic gas-lime may be shovelled round, of course taking care not to hurt the bark.

In Cornwall, where the Pitchy-legged Weevils, or other kinds of Otiorhynchus, injure the fruit to an extent causing serious loss in the great Raspberry gardens, it is found to answer well for men to go round with freshly tarred boards, place the boards below a bush and shake; the Weevils fall on the tar and stick to it. Thus, clearing the Weevils and retarring the boards frequently, the Weevils are got rid of at a paying rate.

The principle of alarming the Weevils, so as to make them fall, may be applied to many kinds of Weevil attack, bearing in mind that the Weevils commonly fall on the first alarm; and we must give a little attention to their habits, or they may all have dropped down and secured themselves before we have set about frightening them in full form.

The Otiorhynchi (the Vine and Pitchy-legged Weevils) feed by night, and on the gleam of a light they will drop; therefore if a lantern is taken to begin operations with we are apt to find nothing to catch.

Several kinds of Weevils feed on Peas, Beans, and Clover leaves, doing thereby most serious harm.

The terribly destructive Pea Weevils (see Fig. 84, p. 106) were formerly supposed to feed only by day; then they fall at the vibration of a foot, and bury 
themselves. There may have been hundreds a minute before, but you will very likely not see one; but beat the ground with a spade and you will most likely see them all struggling up out of the earth again. More recently, however, observations have shown that they may be found at night working at the edges of the leaves, and then it is stated they are not nearly so. susceptible of alarm.

Up to the year 1882 nothing was known as to the

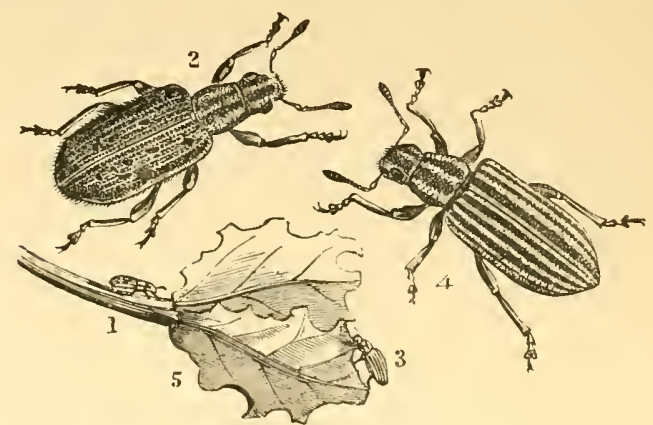

Fig. 84.-Pea and Bean Weevils, nat. size and magnified; 1, 2, Sitones crinitus ; 3, 4, S. lineatus, nat. size and magnified.

early history of these Sitones, but in that year (from different field observations) it was found that they lived in maggot state on the roots of the plants of which the Beetles devour the leafage, and that they went into pupa at the roots. These observations, made by Mr. Christy in Essex, and Mr. Thos. Hart in Kent, may be well pointed to as examples of the great benefit accruing from field observations of agriculturists, instead of simply trusting to instruction to be gained from lectures or so-called "scientific" instruction! All true teaching is good, but it should never be forgotten that what is called scientific teaching, in agricultural matters, is the recorded result of observation, or of deductions from observations. The practical observation of to-day, when it has been 
verified and put in form, becomes the "scientific". instruction of a later date.

Returning now to the ravages of the Sitones, commonly known as "Pea and Bean Weevils," these may be told by the semicircular scoops eaten out of the leaves. We find these attacks the worst to the leafage of young plants, especially when, from weather or other circumstances, the plant is kept back, so that it cannot grow away from them; but the Weevils are to be found in legions later in the year, and sweeping these up, as they are to be found in the waggons when Clover or Peas are being carried, would get rid of some amount of coming attack. The main point we seem to need here is to prevent the settlement of the autumn brood of Beetles. These fly well, and have been found to shelter themselves in the top joint of Corn stubble, and from this they come out to set on foot attack in Trifolium, or Clover, drilled after. Also it has been noticed that where Wheat-sheaves stood long in harvest-time, the Clover on these spots was free from attack in the following spring, although that on the rest of the field was attacked. Acting on these observations, skimming the surface stubble, so as to get rid of the shelter, has been considered useful; and a good liming, or other chemical dressing, much of which would go into the stubble and make it a very undesirable home for the Weevil, would help us. All measures which will push on good growth are valuable preventives in this case; and in gardens it would probably do a deal of good to lay the drawn and useless haulm along the rows, witl any dry rubbish, and burn it. It appears to be the nature of this Weevil to come up, not to go down, on alarm; and we might thus clear out the parents of the next spring's attack.

The small long-smouted "Pear-shaped" Clover Weevil, Apion apricans (see Fig. 81, p. 101), also does much harm to Clover leafage; but in this case the grub lives in the seed-head, and feeds on the young forming seed; and the best known method of prevention is 
cutting the Clover before the flower is fully out. These Pear-shaped Weevils (Apions) are so very small that they are hardly observable, but the damage to the leafage, or patches of brownish heads in a field in flower, shows where they are at work.

There is yet one more of the common Weevil attack of the Bean crops to notice; it is that of a small short-snouted Weevil (black with brown hairs and
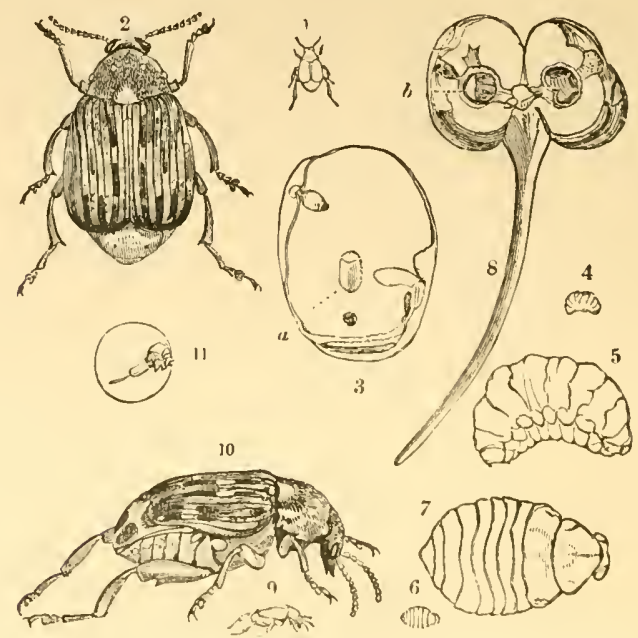

Fig. 85.-1-8, Bean Beetles, grub and pupa, nat. size and mag.; injured Beans; 9 and 10, Pea Beetle, nat. size and magnified; 11, injured Pea.

white markings), which is often found inside Broad Beans, with no signs outside of how it got there. The attack happens thus:- When the Bean-pod is still in its very youngest state, even still in the blossom, the Buetle lays its egg there; the maggot, which hatches from it, lies in one of tlie young Beans in the pod, but the hole by which the egg was put in, or the maggot crept in, is so small that it grows np completely with the growth of the Bean. When the Beans are ripe 
and garnered, the maggot is there too. It feeds within; and though it does not prevent the Bean sprouting, yet it lessens the size of the seed-leaves, and consequently weakens the first growth, and thus damages the strength of the future plant. Here one good method of prevention is to examine a sample seed, to find whether it is infested. The maggot turns to a Beetle within the seed; but before it does this it eats a tunnel to the outside, only just leaving the outer skin at the end. This, having nothing behind it, sinks in, as if a knitting-needle had been slightly pressed on it. By this little round dented-in mark you may know infested seed; if, instead of the mark, there is a small round hole, the Beetle has completed its work within, and has gone. By these two marks you may judge as to the state of the seed; and further, if there should be the mark showing the Beetle is still within, it is unsafe to sow, as attack will follow. The Beetles will presently come out, and as soon as the Beans in which they were sown have grown, and are in flower, their sometime tenants will mount to the blossoms, and lay eggs to start a new attack. The Bean Beetles begin to appear in February, and for this reason autumnsown Beans are the most likely to be infested, as the Beetles are still within.

During the last few years it has been found that dressing infested Beans, before sowing, with a mixture of $1 \mathrm{lb}$. blue vitriol, and 1 pint of McDougall's sewage carbolic to 6 quarts of water, answered well. The above mixture is enough for six bushels of Beans.

The Cabbage and Turnip Gall Weevils do harm under ground. The female lays her egg on the root or the under-ground part of the stem, or in a hole in it which she forms with her snout; and in consequence of the irritation thus set up the small lumps form, which we know as Galls. In each of these the maggot hatched from the egg feeds, until it is full fed. Then it gnaws its way out and forms an earthen case, in which it turns to a pupa, and thence to a Weevil. 
The maggot does not care for cold. It will mend its earthen case if it is broken; and even if it is buried by the galls on the Cabbage stalks being dug in, it appears to thrive as well as if they were still growing. Therefore, it is a great object to get rid of all nurseries

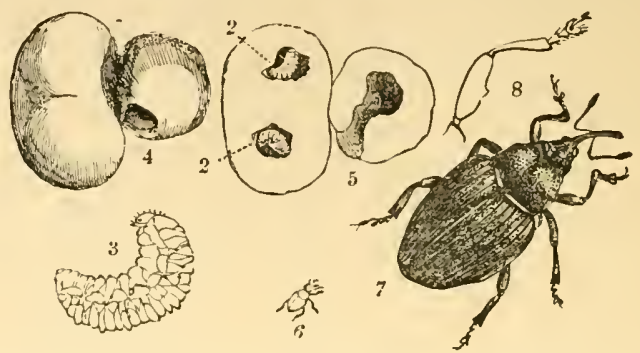

FIG. 86.-Turnip Gall Weevil and maggot, nat. size and magnified. Leg of Weevil, magnified. Turnip Galls.

of future attack by burning or otherwise destroying old stems with galls, instead of throwing them to a rubbish-heap or digging them in ; and a change of crop is useful, by presenting food that they cannot eat, or find useful to lay eggs in, to the Gall Weevils that may be waiting in the ground.

These Gall attacks are not very injurious in themselves, but in the case of Cabbage they are often found in connection with Club. They do not directly cause it. The two attacks are quite different, one being a diseased growth set up from insect attack, the other a diseased growth from presence of a fungus, scientifically the Plasmodiophora brassice, popularly a slimefungus. This fungus exists in the soil, and when established is very difficult to be got rid of, and remains of infested roots, that is, Cabbage roots with "club," or 'Turnip roots with "anbury," propagate it largely.* One great preventive of recurrence of

* When the series of Lectures, of which this little volume is a republication, were given by myself, in 1883, the fact of "club" and "anbury" being originated by fungoid presence was not, so far as I an aware, generally known in this country. A very good chapter on 
attack is gas-lime, which is also good as a preventive of the Gall Weevil attack.

Dressings of lime are very serviceable to prevent these kinds of attack, both in Cabbage and Turnip. Gas-lime and wood-ashes are also good preventives, and probably kainite, which contains much potash, and which is not nearly as much used as it ought to be, would be very useful. Marl or fresh soil is useful in old garden ground, and deep trenching, which throws fresh soil to the top, and buries the Weevil maggots so deeply that the Weevils from them have not strength to come up through the soil above them, is also a good treatment.

Before going on, it may be well to notice that these notes of method of attack are not offered as complete accounts of the history and method of prevention of any of the attacks, but as instances of special points to be looked to-of habits, that is-that many crop pests have in common, and of means of treatment, of which some one or other may be serviceable for the attacks of many insects.

In many of the Weevil attacks which we have been studying, treatment of the surface of the ground is a great point; as, for instance, where they shelter under rubbish, or down stubble, to clear away these shelters, and put on dressings which will be thoroughly obnoxious to the Weevils, is good treatment. Where the Weevils, or their grubs, are in the ground, it obviously is well to turn them out on the surface, or bury them by trenching so deeply that they cannot come up ; and also, so to dig in, or otherwise apply, chemical manures, as to make the soil unpleasant at least to the pest, and so good for the plant that it may grow away from attack.

the subject will be found in 'Diseases of Ficld and Garden Crops,' by Worthington G. Smith, pp. 94-104, published in 1884. Various conditions of land or ehemical manures were known to affect amount of "club," but, as far as I am aware, it was not known that these acted not so much by immediate effect on the plant as by destruction of the slime-fungus.-ED. 
It is in working such points as these that true serviceable plans of insect prevention consist. We need to know the habits of the crop "pests." If we can get them told to us on application, or can study them in published accounts, of course it saves time and trouble; but still these accounts, if they are worth our study, are drawn up from observations of habits, just such as we are able to make for ourselves; and if those who depend for their livelihood on the growth

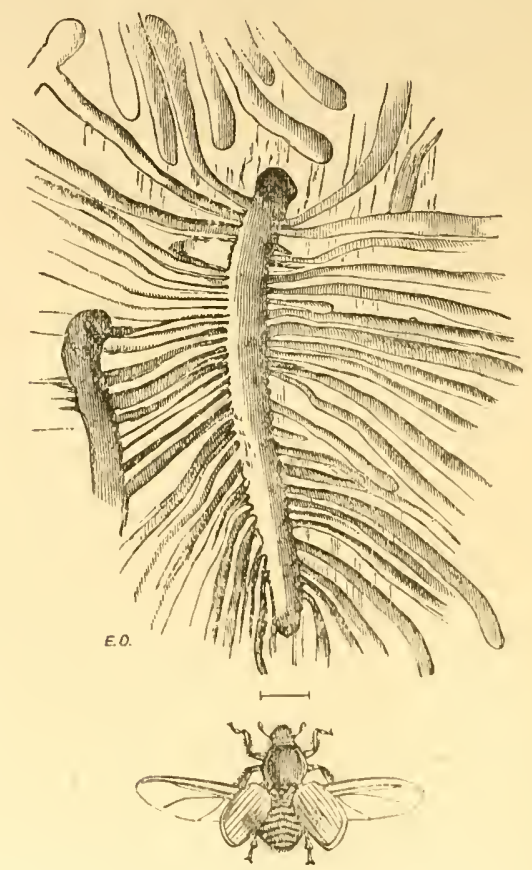

FIG. 87.-Elm-bark Beetle, magnified ; and maggot workings in Elm bark.

of their crops could be induced to believe in their own powers of gaining the needed information, and to use this, as their knowledge of farm operations would 
point out could be done, it would be an enormous saving to them and to the nation.

But to return to Weevil attacks. There is a class of Weevils which do much harm to some of our forest trees, which may be just alluded to, as the carrying out of farm service much depends on sufficient timber supply.

Fig. 87 shows workings of the Elm-bark Beetle (much like those of the Pine-bark Beetle); and Fig. 88, of the Ash-bark Beetle, which has the entrance-tunnel in the centre, and is then forked.

These various Beetles burrow under the bark, or rather between the wood and the bark, and form tunnels an inch to two or more in length, and along each side of these the female lays her eggs. Each grub hatched from these eats for itself a tunnel, running more or less at right angles with the mother's gallery, and at the end of these tunnels the grubs turn to chrysalids, from which, when the Beetles develop, they gnaw their way through the bark.

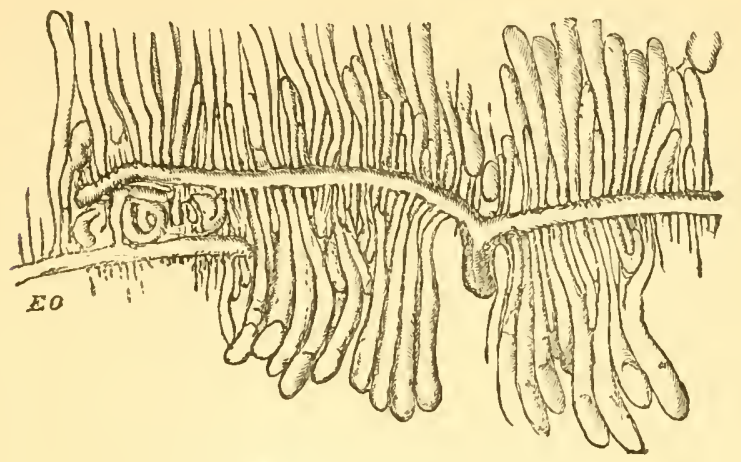

FIG. 88.-Maggot workings in Ash bark.

These Beetles mainly attack, for egg-laying, either newly-felled trees, or unhealthy timber, or broken timber or stumps left lying about; but though in 
this respect they do little harm, yet in other parts of their life they do great damage.

One kind of Pine Beetle bores up the shoots, and another devours the leafage; the Elm-bark Beetle hastens the death of many a tree, which would have stood long without the attack; and the Ash-bark Beetle pierces into good wood for its winter shelter. It is highly desirable, therefore, not to allow useless wood to be about, or infested logs, or trees to remain to attract or spread attack; but the details of this forest management we have not space for now.

The next section of beetles of the division of the Tetramera, or Pseudo-tetramera, is that of the Longhorned Beetles (Longicornes), of which the grubs

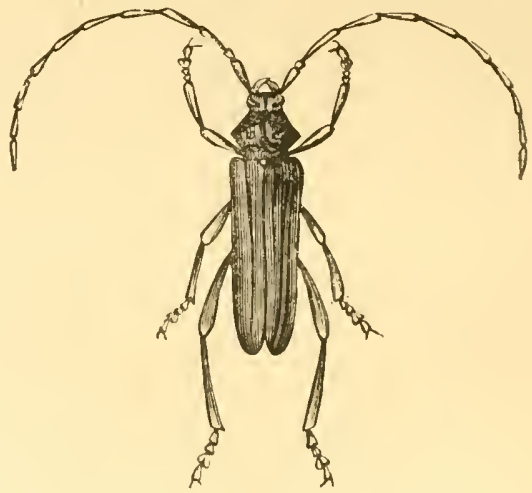

Fig. 89.-Nusk Beetle.

chiefly frequent timber. The Musk Beetle (Aromia moschata), the narrow dark green Beetle, about an inch, or rather more, in length, with two long threadlike horns, gives a general idea of the appearance of the Beetles of this section; but we will pass on to the more important one, to us, of the Turnip Flea Beetles and their allies (Eupoda or Phytophaga). 
This tenth section, the third section of the division of the Tetramera, includes-besides the Turnip Flea Beetles, and some other kinds very like them, which

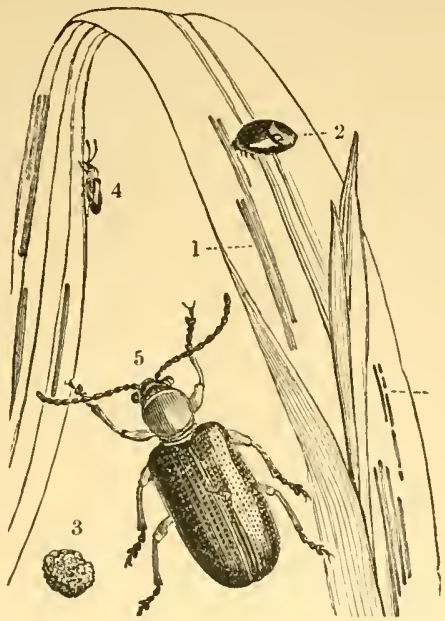

FIG. 90.-Oat Beetle, nat. size and mag. ; 2, grub; 3, cocoan.

feed on Hop-the Mustard Beetles (Fig. 91, p. 116), and others which feed (as the Oat Beetle) on the leafage of various field or garden crops, or on trees.*

We may know them, firstly, by their (apparently) four-jointed feet; and from the other two sets of Beetles of this four-jointed division we may know them by never having snouts like the Weevils, and by (generally) not having long horns. They are commonly of small size, oval shape, and bright colour,

* The attack of this Beetle may be known by the brownish slug-like grub eating the skin of the leaf in lines, as slown in the figure. 'The Beetle is not uncommon from spring to autumn on corn or rushes. It is of a deep greenish blue, with reddish orange fore body, and somewhat less than a quarter of an inch long. Sce Curtis's 'Farm Insects,' p. 307. 
with the head sunk into the fore part of the body up to the eyes.

The figures will give a better idea of the appearance of these Beetles than any description.

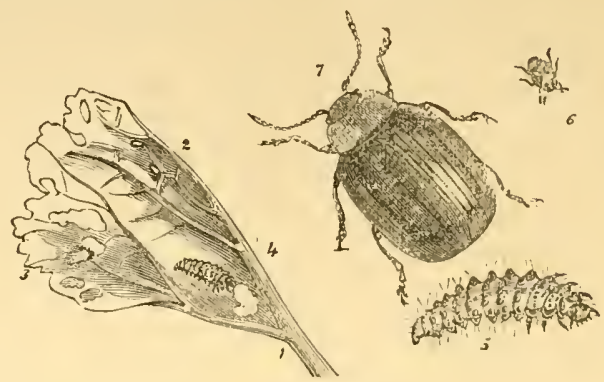

FIG. 91.-Mustard Beetle, nat. size and magnified; grub, magnified.

The Turnip Flea Beetles are well known for their leaping powers. They live during winter under clods, or in dry stone walls, or any convenient shelter, and

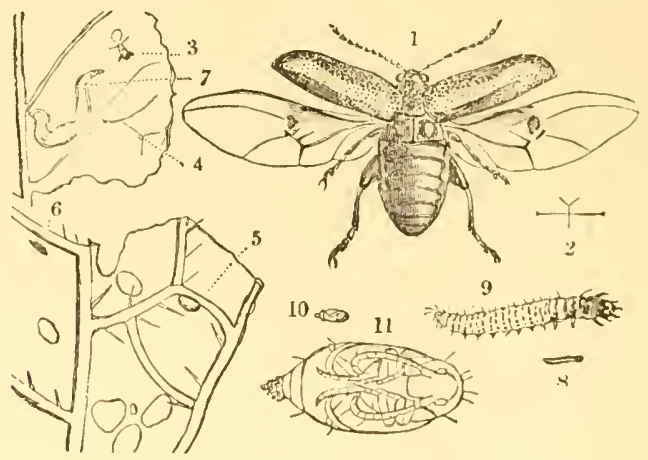

F'IG. 92.-'Turnip Flea Beetle, eggs, maggot, and pupa; nat. size and magnified.

come out with sunshine in spring. Then they feed on any plant of the Cabbage kind; Charlock is an 
especial favourite, until the young Turnip plants are come up. Presently they lay their eggs (if on Turnips) on the under side of the rough leaf, and from these the grub eats its way into the leaf, within which it feeds for about six days. It then comes out, buries itself in the ground, and turns to the chrysalis, from which the Beetle appears in about a fortnight, ready to begin a new attack.

The first point in prevention is to take care there is as little winter shelter as possible. Lumps of manure and clods of earth on the field; heaps of stones and rubbish, such as are often allowed to lie in corners of fields; large amount of dead leaves on the borders of woods; and dry dykes, or open stone walls-are all winter shelters.

Another point is to let there be as few weeds as possible to keep the "Fly" alive. If it does not find suitable food it will die, or remove itself. It has a power of perceiving where its food is; and such plants as Charlock, or the white-flowering Jack-by-the-Hedge, or Shepherd's Purse, will all help to keep it alive till our Turnips are ready. Thus we may lessen the amount of coming attack; but the great point to depend on for carrying the Turnip erop through "Fly" attack is judicious preparation of the ground,-plentiful supply of enrichment, including a good amount of artificial manure, and liberal supply of seed.

The "Fly" does most harm to the Turnips whilst they are still in the seed-leares; therefore all means should be used to give a good start, and run the plant on in a hearty growth. For this purpose the land should be well prepared beforehand. Where climate allows, autumn cultivation is best. Thus the surface soil is broken down by the winter frosts, and there is a good tilth on the surface, with absence of the clods which shelter Fly and cause a dry top, instead of the evenly evaporating surface which suits the young Turnips. When thus cultivated beforehand, the land does not require ploughing again in spring; 
scarifying is enough; and thus the supplies of moisture which have gathered below the surface during the winter remain undisturbed; whereas if the ploughs are put in, the soil is turned up to a much greater depth, and instead of a mellowed surface with good moisture below, we part with the stores which, in a dry season, would have made all the difference of life or death to the crop. The Turnip plant is of such a succulent nature, that the point of supplying it with enough moisture is one of the main things in all methods of starting it.

It is advised to let the land remain untouched for a few days before drilling, with a view to the surface not being dried by exposure just before sowing; and the effect of what seems just the opposite treatment, namely, to sow at once, when partly rotted manure is ploughed in, in spring,-is, for the same reason, to secure the moisture. But whenever it may be necessary to work the land, one great point is to secure such a state of under soil and upper tilth as will push the plant on; and by no means trust to a mere good tilth, if it is gained, as is sometimes done, by turning the land over in the sunshine and heat until we fairly see the dust rising, and, as it has been well remarked, it is as dry as if we were making hay. Turnip Fly delights in heat and drought, and the Turnips in just the opposite.

Liberal seeding-3 llos. or more per acre-answers well; for if Fly comes there is a good chance of some of the plants escaping, and if it does not the surplus quantity may easily be removed. In either case, the large number of plants helps towards a hearty start, as the many small leaves prevent the moisture beneath evaporating, as it rould from bare earth, and thus keep a damp air beneath the leaves. Good seed is also very important, so that it may sprout at once, and witl vigour.

'I'o gain this hearty and rapid growth through the time of the seed-leaves is one of the reasous of apply- 
ing artificial manure before sowing, or drilling it together with the seed. A few hundredweights of superphosphate, or other manure suitable to the land, even if there is a good supply of farm manure also, will run the plant on rapidly through the growth of the seed-leaves; and when the rough leaves are come the greatest danger is past.

Where a crop hangs back, the use of the water-cart has been found useful, and also putting in the seed with the water-drill; but if weather should be dry at the time of souving, there is fear of the small supply of moisture put in by the water-drill causing harm (by the mere temporary effect) rather than permanent growth.

When attack is present, various fertilisers have been found to do good by pushing the plant on; but all applications intended to serve by removing "Fly," or killing it, should be used either when the dew is on at night or early morning, or during damp by day.

The Turnip Fly leaps away when it finds attack coming; but if the dew or slight rain is on it, it cannot leap, because the moisture clogs the hind legs, by means of which it takes its great springs. Therefore, such measures as driving sheep through infested fields, or laying on special dressings, often fail, because they may have been clone at the time when the Fly is well able to avoid receiving harm. Turnip Fly attack is one of those that it would be well to enter on, if possible, in full detail, as an instance of those which only last for a short time, and which we conquer by methods having for the most part very little to do with the insect itself. We know that the Turnip is chiefly in danger whilst in the seed-leaves; we know exactly what will suit its growth in this state, and we make ready the ground accordingly; also we clear away weeds which would support the "Fly" when the crops are not present for it to feed on.

These principles may serve also in treatment of the Mustard-seed Beetle (Fig. 91, p. 116). This shelters 
much in old Nustard straw; this straw, therefore, should be destroyed; also the old reeds by ditches, where it harbours, and the ditch-growing plants, such as Brooklime and others, on which it feeds in spring, should not be allowed to get numerous. Sowing as early as possible, and sowing Brown instead of White Mustard, because it comes earliest of the two, and thus avoiding the special season of attack, are found to answer; and also a vigorous growth, such as will not go down at once before attack, is of great use. But, in the case of this plant, which is grown to a great extent in special districts, one great means of prevention is more frequent change of crop.
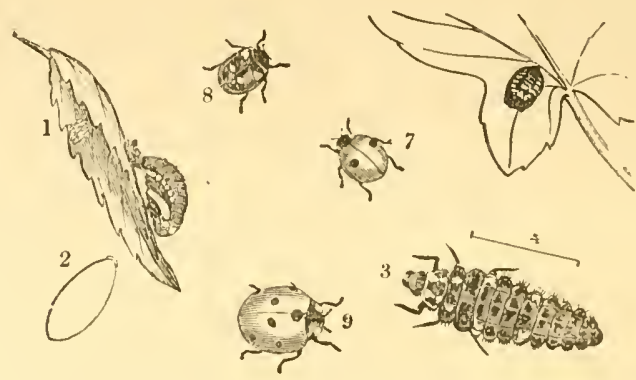

Fig. 93.-Ladybirds : chrysalis, egg, and grub, nat. size and mag.

This point of rotation of crop as a means of insect prevention will be alluded to presently.

The remaining division of Beetles is the section of the 'Trimera (or I'seudo-trimera), which includes those which liave apparently only three joints to their tarsi. "They are, however, really composed of four joints, the second, which is bilobed, receiving the very minute third, and the base of the apical joint."-E. C. Rye.

The most important family in this section is that of the Coccinellirle, which includes the well-known Ladyhird Beetles, figured above. The common red and hack-spotted linds of these Beetles are very familiar, 
and the figure shows the appearance of their sixfooted slaty and orange-spotted grubs. Both as Beetles and grubs they feed on Aphides of various kinds, and are of such great service in keeping down the Hop Aphis that they should never, on any account, be destroyed. They are best known with us for their serviceableness in keeping down Aphides or Plant Lice; but it is not only limited to this, and in other countries two distinct species are of great service in lessening amount of presence of the socalled "Australian Bug," the fluted or Woolly Scaleinsect. 


\section{CHA P TE R VI.}

\section{BUTTERFLIES AND MOTHS (LEPIDOPTERA).}

Cabbage Butterfutes, Surface Caterpillare, Weather Effects, \&C.

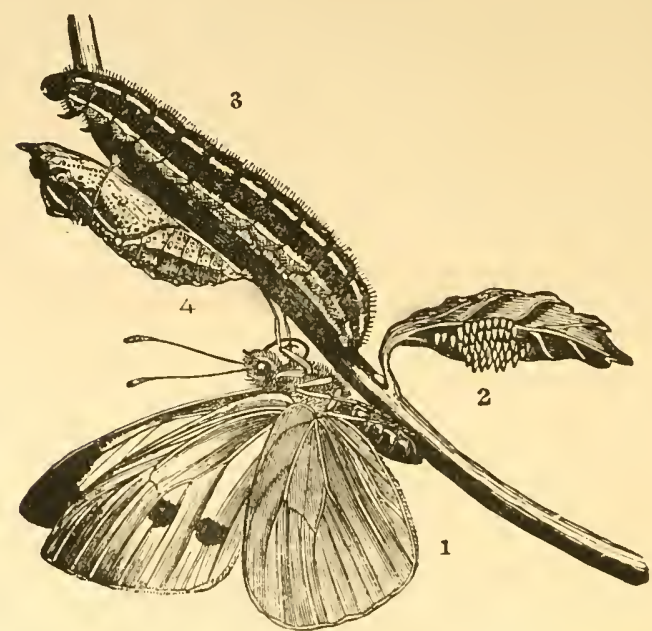

FIG. 94.-1-4, Large White Cabbage Butterfly: eggs, caterpillar, and chrysalis.

BEFore continuing this course of observations I wish once again to draw attention to their object being not so much to give an account of the different kinds of insects which attack our crops, as of the chief different methods of attack. Thus, by studying the points of some one kind of attack, we see for ourselves that all other attacks which have the same chief points may be lessened by the same kind of treatment. For instance, whether it is grub or caterpillar, or beetle, 
that is feeding on leafage of trees, if we can make them fall, and prevent them going back again, one principle of treatment will answer for them all; and thus it is in many other cases.

Therefore, in the little space which can be given here to a very large subject, I am, as far as is possible, describing the chief different kinds or classes of attack, and taking some of the worst as patterns or examples of how treatment has been found to answer in these cases, but by no means alluding to each separate kind of insect.

We will now go on to some of the main points in the habits of the order of Butterflies and Moths (Lepidoptera), and observe how far treatment can be brought to bear on the ravages of their caterpillars or grubs.

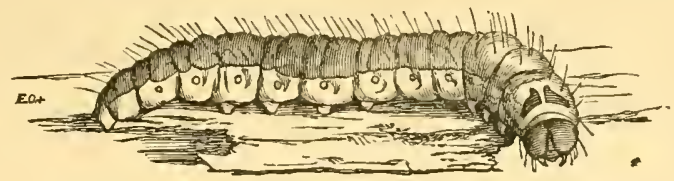

FIG. 95.-Caterpillar of Goat Moth.

We know them by sight too well to need to spend time in description, and we may in many cases know their caterpillars from those of the beetles we have just been studying by their larger number of sucker feet. Besides three pairs of claw feet, and usually a pair of sucker feet at the end of the tail, Moth and Butterfly caterpillars have for the most part from one to four pairs of sucker feet beneath the body; most commonly they have four pairs of these prolegs or sucker feet. They have heads furnished with jaws, and are often very prettily coloured, and sometimes beset with spines, sometimes thickly coated with hairs, sometimes with tubercles. When full-fed they moult off their caterpillar-skin and appear as chrysalids, with the forming limbs beneath them, but all still soft and incomplete. A kind of gum exudes from the surface, which, by 
gradually hardening, protects the insect within, and from this case of thin cement the Butterfly or Moth makes its way out when fully formed in all but the expansion of the wings. These, however, very soon spread to their full extent, and the insect is then complete.

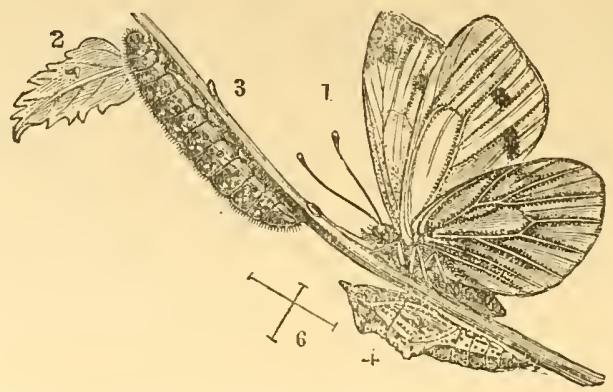

Frg. 96,-Green-veined White Butterfly: 1, female; 2, egg; 3, caterpillar ; 4 , chrysalis.

In a general way Butterflies may be known from Moths by having thin long horns ending in a kind of club-like swelling; also by being day-flyers, and by the habit, when at rest, of setting their wings upright.

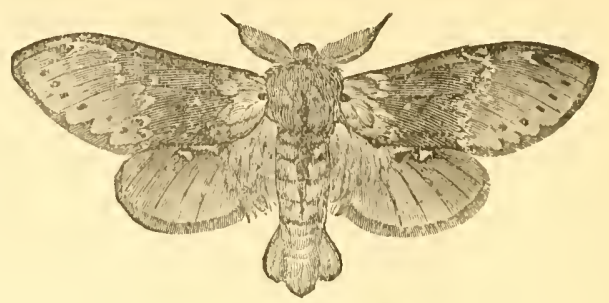

FIG. 97.-Lobster Moth.

Moths usually rest with their wings spread flatly; they have horns of many different forms, some long and thin, some comb-like, other's like feathers, and also they 
often fly at dusk rather than by day, and many are of a much heavier and thicker make than the light graceful Butterflies.

The Butterfly chrysalids (see Fig. 94) may be known from those of Moths by being much more angular, the rows of ridges scooped out or interrupted at distances, sometimes giving almost the appearance of prickles; whilst the Moth chrysalids are oval and smoother.

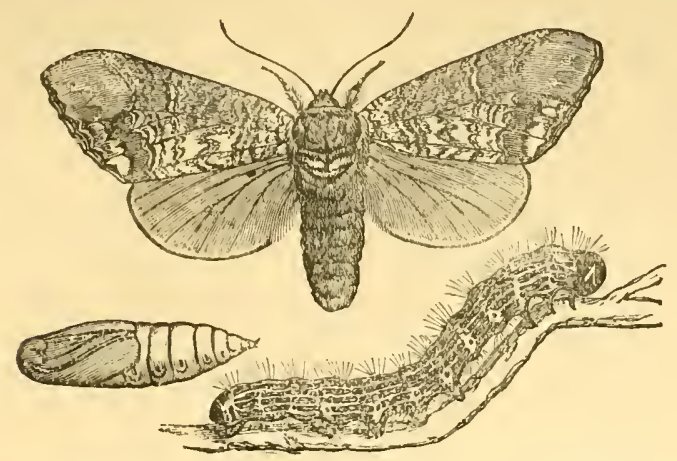

FIG. 98.-Buff-tip Moth: caterpillar and chrysalis.

Chrysalids vary very much in their method of rest during this stage. Some, like the Cabbage chrysalis, are slung up by a silken girdle passed round what we may call the waist, which was spun by the creature when about to cast off its caterpillar-skin, as a support during the coming helpless stage; some hang by the end of the tail from webs; and many go through their change in a silken cocoon (spun like that of the Silkworm by a thread from the mouth), or in earth-cells below the surface of the ground.

In this order a very large part of what we can do to prevent coming attack depends on our knowledge of where the caterpillar turns to the chrysalis state; that is, whether it buries itself, or forms a cocoon, $\mathrm{Or}^{*}$ hangs itself up in sheltered nooks. 
In the case of the White Cabbage Butterflies, of which the caterpillars often do serious mischief in gardens, they have been found not to do so much harm in proportion to field Cabbage, because the caterpillars choose a dry, well-sheltered place to change in. For this they crawl away from their food-plants, and hang themselves by a silken band under eaves, palings, or the like shelter, out of doors, or in any neglected corners in garden-sheds, where they are allowed accom-

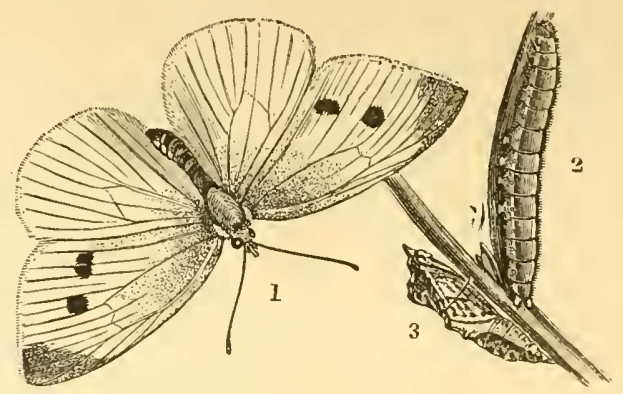

Fig. 99.-Small White Cabbage Butterfly: caterpillar, and chrysalis.

modation, and much may be done to lessen amount of attack simply by tidiness. The collections of old brooms, bits of wood, and dry rubbish of every kind in which they shelter are mucl better away, whether indoors or out; and a brush, taken along angles and in corners, and under stairs, ladders, beams, \&c., in garden-sheds, will sometimes clear the chrysalids out by the handful. A search of this lind between the time of the first and second brood in summer, and some time between November and March, would do much good.

It is an excellent principle to keep down the effect of insect-attack by broad measures of agricultural treatment which will carry the plant well on away from the power of the insect ; but at the same time it should not be forgotten that when there are a great 
number of large caterpillars or chrysalids plainly to be seen, and easily to be laid hold of-whether with fingers or by other means - the best thing to do is, forthwith, to lay hold of them. In some cases hand-picking is perfectly ridiculous, but in some it is
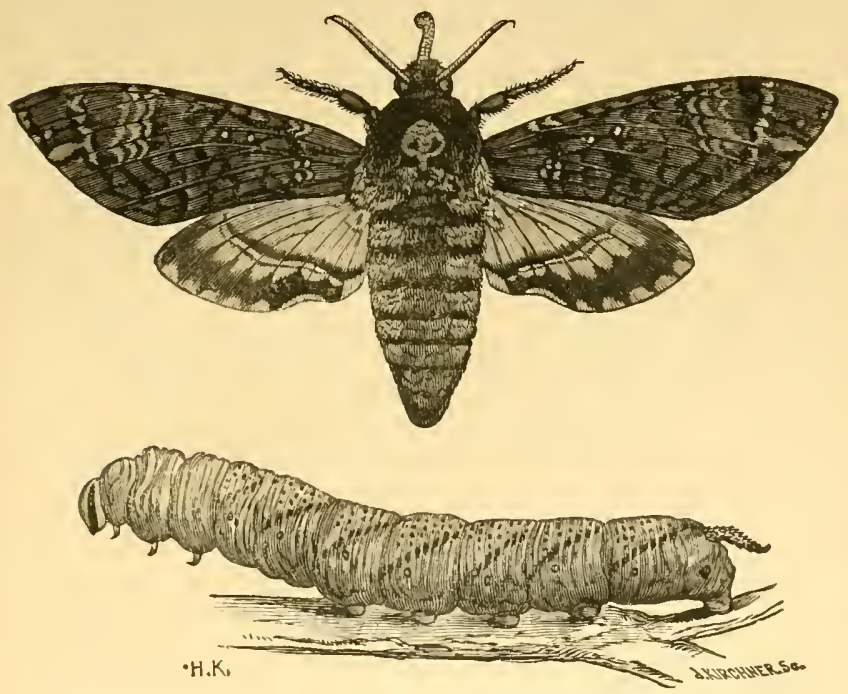

FIG. 100.-Death's Head Moth and caterpillar.

not only a sure cure, but a very cheap one. It does not follow because it is hand-picking that the caterpillars, or what not, are to be taken off one by one, or that men, at a man's proper wage, are to be employed; but if children are shown precisely what they are to do, and paid so much per hundred or per pint, they will soon prove of great service. In Germany hand. picking is much used. It is noticed at what time of day the moth or beetle, or whatever it may be, is most sluggish; commonly this is on damp, sunless days, or early in the morning. When it is linown what the best time is, the women or children shake the attacked 
plants above baskets, or above anything that will catch the falling creatures, be they caterpillars or anything else, and thus at a small sum they are collected and destroyed.

There are not many kinds of butterfly caterpillars. which are hurtful to crops in England; but amongst the hosts of different kinds of moth caterpillars that cause great loss, about the very largest of all, which is that of the Death's Head Moth, is best got rid of by hand-picking. This sometimes does much harm to

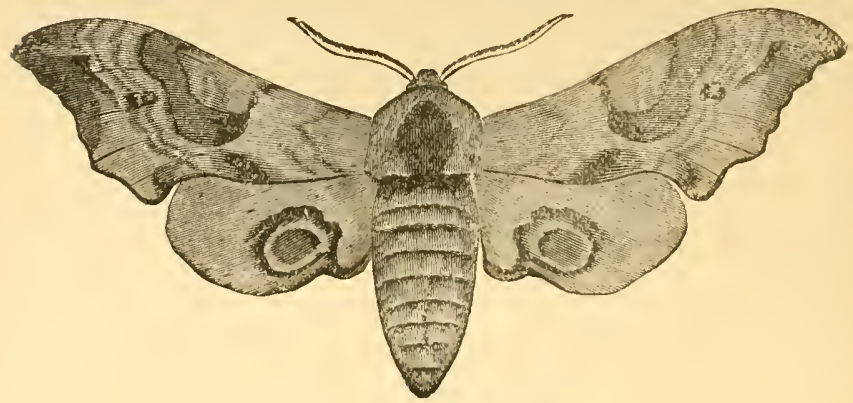

Fig. 101.-Eyed Hawk Moth.

Potatoes by feeding on the leafage. The caterpillar is as much as four or five inches long, and as thick as a finger. It is yellowish, with slanting blue or blackish and white stripes on the side, and, like most of the caterpillars of this family of Hawk or Sphinx Moths, has a kind of horn-like growth, like a short curved and pointed tail. The richly-coloured brownish Moth is the largest of the British linds; it is linown by its back being marked with a figure like a skull, whence its common name of Death's Head Moth.

The caterpillar usually liides by day, and feeds in the evening or at night; therefore, when great larm is found to be going on (either in this case or others like it) from an unseeen enemy, it is well for some trustworthy person to watch at dusk or dawn for what 
is going forward, and with large creatures like these caterpillars a very small quantity of light will be enough to see them by, as they gently move the leafage in feeding. When full-fed the caterpillar goes down into the ground to change; therefore turning up the chrysalids is an easy measure of prevention with this Potato-feeder.

This family of Sphinx, or Hawk Moth, are chiefly of large size, and of the shape of the Eyed Hawk Moth

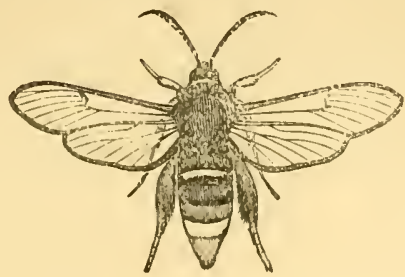

FIG. 102.-Hornet Clearwing.

(Fig. 101). The caterpillar of this feeds on Apple and Willow, and is rough, of a pale green with white stripes on the side, and has a blue tail. The caterpillars of the Sphinxes are mostly much like this, and the caterpillar of the Death's Head, in shape; and this family deserves a word on account of its great beauty.

The habits of the various kinds of Moth caterpillars do not differ so much among themselves as those of Beetle grubs. Some caterpillars of sereral families of Moths bore up stems or timber ; some of several, or at least of two, families work together in great parties, which form webs for their head-quarters; some of many of the families bury themselves to turn to chrysalids. We will therefore look at the class of habits together, and first take the borers.

There is one family amongst these, known as the Clearwings, which differ from other Moths in the body being usually straight and narrow, and the wings so 
transparent that they much resemble Flies, Wasps, or other transparent-winged insects, from which they are consequently scientifically named. One of the largest is the Hornet Clearwing, the caterpillars of which infest the Osier.

The caterpillars of the Clearwings are white fleshy grubs, with altogether sixteen feet; and they feed in

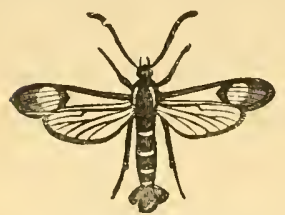

FIg. 103.-Currant Clearwing. roots, wood, branches or shoots of trees, and turn to chrysalids in the gallery which they have eaten. The Currant Clearwing sometimes does much mischief. The egg is laid early in the summer, in some crevice such as is often to be found on old or badly trimmed trees; from this the caterpillar, as soon as it hatches, eats its way into the branch, and, for several inclies downward, feeding on the pith as it goes, and feeds or lives, in the caterpillar state, within the bough till the following March.

The clirysalis is to be found about the beginning of May. Where large branches of Currant bushes wither away, or young shoots fade without known cause, it may be suspected that this caterpillar is within, and splitting the shoot open will soon show whether it is there. If so, all shoots that are, or are suspected of being, attacked should be cut off and destroyed; but the best preventive is trimming that will not leave numbers of old neglected boughs in the bushes.

Where caterpillars bore into solid growing wood, something in the way of prevention may be done (to begin with) by noticing what part of the tree is commonly chosen by the Moth for egr-laying, and using means to protect this. The habit of the Goat Moth is to lay her eggs in crevices in the rough bark near the lower part of the tree, which may be Oak, or Fim, or Willow, Apple or Pear, or various other linds of our deciduous forest or fruit trees. The 
caterpillar may be known by its great size* (for it is three inches or more in length), joined to its yellowish colour, with reddish patches or stripes down the back and black head, and the strong and peculiar smell from which it takes its name. It bores into the live wood, and lives there for three or more years before turning (in a cocoon roughly spun up of small bits of

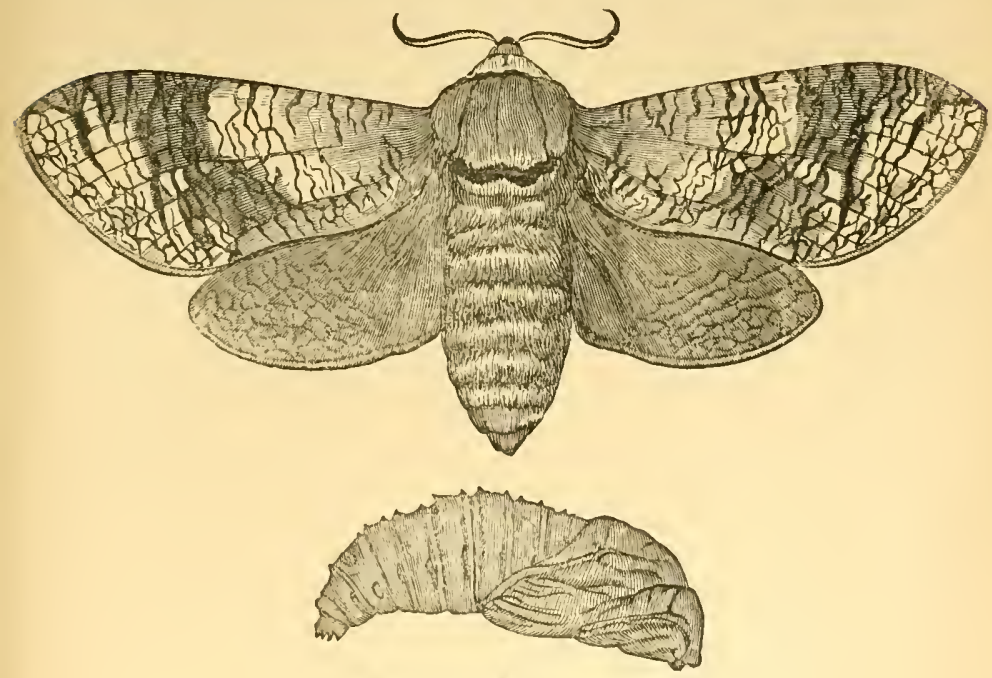

Fig. 10t.-Goat Moth and chrysalis.

wood just inside the entrance of the burrow) to the chrysalis stage.

The means by which the grub can be attacked in its burrow are applicable to many timber-burrowers. Something may be done by thrusting a stout wire up the boring; if the end comes back moist with white matter on it, the caterpillar has been reached; or, by means of a hooked wire, the caterpillar, when feeding near the outside of the tree, may be drawn out. Another very good plan, when the caterpillar is

* See figure of caterpillar, about half-grown, p. 123. 
further in, is to inject paraffin, by means of a sharpnozzled syringe, into the tunnel; any other fluid poisonous to the caterpillar would do just as well; soft-soap or tobacco-water, for instance, or fumes of anything poisonous, such as sulphur or tobacco, might be applied in the same way; and a bit of soft clay kept well pressed up to the mouth of the hole, so that it might be forced in like a plug as the syringe or tube was withdrawn, would keep the application from escaping. This seems a very simple thing to name, but for want of it an endless amount of damage goes on to the fruit and forest trees, both at home and in the colonies. Sometimes there are as many as sixty of the Goat Moth caterpillars in one tree. I have myself seen up to that number taken from an Elm, and in such cases felling the tree, and destroying the caterpillars, is the best prevention for the spread of mischief.
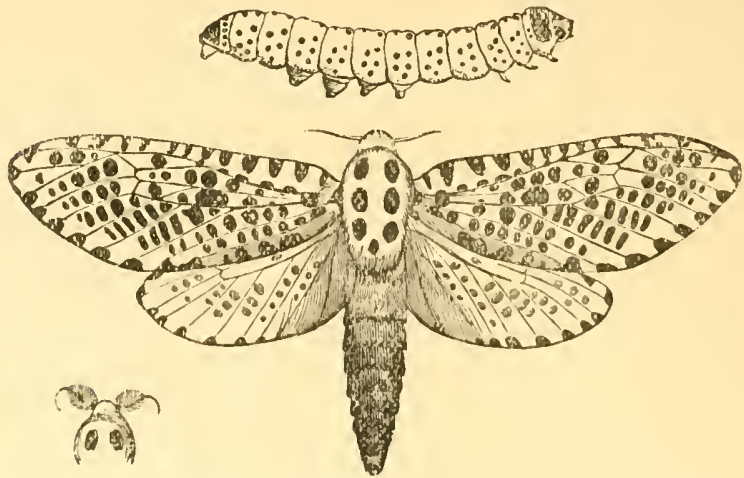

Fig. 105.-Wood Leopard Moth: female, head of male, and caterpillar.

The black and white Wood Leopard Moth is another kind, of which the caterpillars do mischief by boring passages in the living wood; but in this case the branches appear to be more especially attacked, and in my own observations I have found fruit trees morc 
affected than timber. The caterpillar is white or yellow, spotted with black (figured, p. 132), and precisely the same remedial measures are applicable as for the destruction of the caterpillar of the Goat Moth.

The various kinds of attacks of Moth caterpillars are so many, and the injuries they cause so great, that in whatever point we may select now for study it seems at the cost of leaving out something else of importance; but in these short dry details I have tried to draw attention to some four or five principles of preventing or remedying attack:-

One is taking away shelter (as in the case of Cabbage caterpillars). Another, the possibility of liand-picking, shaking down, gathering, or whatever term we use for it, being so managed as to be a practicable and paying operation, instead of a ridiculous loss of time. Another is prevention of egg-laying on fruit bushes, by keeping them so properly pruned that there is no attraction of cracks and crevices. We have also noticed that the caterpillars may be smoked or poisoned in their burrows, - a simple piece of knowledge, but yet one which some few years ago would have been of great service in saving Coffee shrubs in one of our colonies. Further, we have noticed that with webbing caterpillars it is decidedly well, before we pay our visit, to see if the family are at home.

Orchard Moth-caterpillars, that is, the caterpillars of moths of various linds, and various also in some points of their structure, and in many points of their habits (excepting that of damaging or totally devouring the leafage of our common orchard fruit trees), are a class of injurers to which for some years back attention has been absolutely necessitated.

With the great increase of the fruit industry, we have now areas of thousands of trees where formerly these were counted by hundreds, and we have a consequent increase in amount of the attendant fruit-tree insect vermin. Where there is a large extent of 
plant growth of any kind, orchard trees or otherwise, affording food in their feeding condition, and shelter in their other stages to special kinds of insects all the year round, and for successive years, there these insects are sure to be present. This has been the case in such a marked and increased degree during the past few years, in some of our fruit-growing localities, as to necessitate adoption of some special measures of prevention suitable to the special habits of some of the kinds of caterpillars, and also of remedial applications suitable for sweeping them all off and destroying them together (whatever their other habits. may be), when broadscale ravage on the leafage calls for broadscale clearance.

One very important division of caterpillars to which measures of prevention can be applied, is that of the "looper" caterpillars of various kinds of motins, of which the females are either totally wingless, or the wings are abortive to such a degree as to prevent them being of service in flying. Of these, two of the most

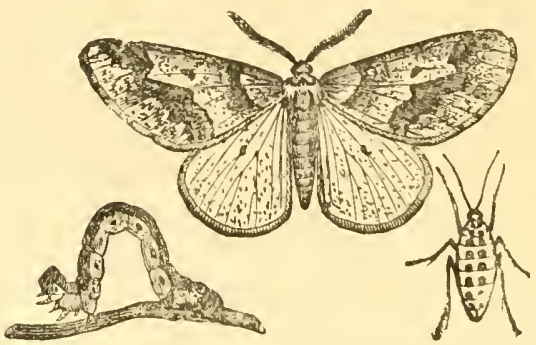

Fig. 106.-WIottled Umber Moth: male and wingless female. Caterpillar, after Taschenberg.

hurtful kinds are the Mottled Umber (IIybernia defoliaria (Fig. 106) and the too well-known "Winter Moth," sometimes also lnown as the "Evesham Moth."

The male Mottled Umber is about twice the size of the Winter Moth, with the fore wings usually of a 
pale brown or reddish yellow; the hinder wings paler. The wingless females are brown, with two spots on the back of each segment; the caterpillars may be generally described as brown above, yellow at the side, and greenish yellow beneath.

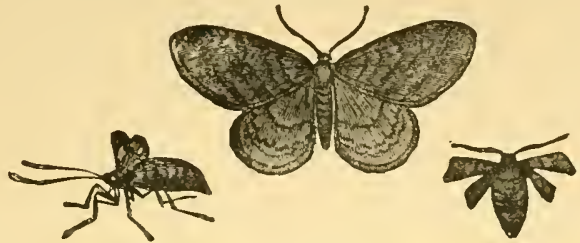

Frg. 107.-Winter Moth (Cheimatobia brumata): male and wingless females.

The male Winter Moths have the fore wings marked with various shades of grey, with paler hinder wings. The females, though not absolutely wingless, are only furnished with such short wings that they are useless for flying purposes. Their colour is grey, with darker bands, as figured. The caterpillars are so variable in colour, and differ so much after successive moults, that it is hardly possible to give a clear description; but they may be generally described as at first greyish or greyish green, with dark heads and faint white stripe along the back, and afterwards of a clearer green, this, in the last moult, being of a yellower tint; there is also a dark line more or less visible down the middle of the back.

Both of the above-named kinds of caterpillars are "loopers," that is, form an upright loop in walking (see Fig. 106). This is consequent on having, instead of four pairs of sucker-feet below the body, only one pair besides the pair at the end of the tail, so that the caterpillar cannot move continuously forward, but has to bring the sucker-fect on to where the claw-feet are holding firm, and thus progress in a series of upright loops. From this somewhat geometrical figure, like an arch or a pair of compasses, the caterpillars are 
sometimes known as "Geometricians," and the family of moths to which they belong as the Geometrida.

The method of life of both the above kinds is for the caterpillars to hatch in the spring, on the orchard trees on which the eggs have been laid, and feed on, or possibly fairly ravage, the leafage and all the soft growths, during a period which may be from about the end of March until the end of June. Then the caterpillars leave the trees, and go through the change to ehrysalis state beneath them. This may be just about the surface of the ground or a little below. From these the moths begin to come ont in October or November, and the wingless female moths creep up the trees and deposit their eggs. This habit, if the moths only went up the trees during a special period, would put means of prevention at once in our hands. But even as it is, the infestation may be greatly reduced by putting bands of sticky material round the trunks, such as will either deter the moths from trying to go up, or hold them firm if they try to cross. This plan eatches the moths by hundreds on each tree, but care must be taken lest the mixture applied should injure the bark. On the rugged thick bark of old trees, where the outside is a mere dry dead coating, it is possible that even tar may be applied without doing harm, though not without risk. But with young trees there is very great danger of serious injury, and sometimes great losses have taken place consequently on tar or grease being applied direct to the bark. The application soaks into the tissues, and the tree in such case perishes.

The safest way is to begin by passing a band of tough grease-proof paper, such as may be procured at very small eost from grocers, round the tree. This may be about seven inches wide, but the wider the better; the ends should overlap, and the paper be secured in its place by a piece of string being tied round near the upper and lower edges. On this the grease may be smeared. A flat bit of wood, like a 
paper-kuife, is a convenient implement for spreading it with, and common cart-grease answers well as a cheap and effective application. Even, however, where the tree is protected, some care must be exercised in the choice of "sticky" mixture selected, as some of the materials sold under the name of "axlegrease" contain petroleum residue, animal grease, or other components, which, like tar, would have very undesirable effects, if (as I have myself seen to happen) they should soak through the supposed greaseproof paper to the bark.

The above treatment does much good, but does not answer perfectly, for the following reason. Though the great body of these moths come out from the middle of October to December, this period by no means includes the whole appearance. We find them still at the end of January, and the later brood may be found coming up towards the end of winter; and at the end of March another kind of Moth, with wingless females, namely, the Anisopteryx rescularia, or " March Moth," which lays its eggs in bands embedded in down on the twigs, is (or very likely is) also present.

All this sufficiently accounts for sticky banding not being wholly reliable as a preventive of infestation of the wingless moths. To be reliably effective the application must be repeated and repeated again, till the aggregate cost is no trifle; and there is the further point to be considered that, bad as the attacks of the looper eaterpillars of these wingless moths are, there are other kinds of orchard moths of which the attaclis come on the wing, or in some manner which cannot be in any way prevented by applications solely calculated to stop attacks coming, on foot, up the trunks of the trees.

There are many linds of these moths. 'The female of the Orgyia antiqua, or Common Vapourer Moth, is 
wingless; but as she does not leave the outside (or the very near neighbourhood) of the cocoon spun on the
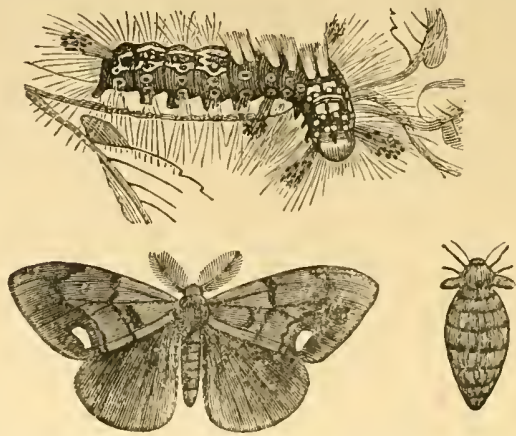

Fig. 109.-Orgyia antiqua : caterpillar (after Taschenberg); male moth; female moth, with abortive wings.

tree by the caterpillar before its change to chrysalis, and on or near which she lays her eggs (see Fig. 110), this attack cannot be stopped by banding. The cater-

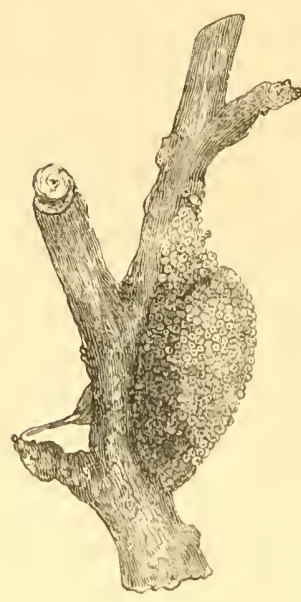

Fig. 110.-Cocoon of 0 . antiqua, covered with eggs.

pillars are very destructive, aná may easily be distinguished by the tufts of yellowish or brownish hair on the back, and the long bunches of dark pin-headed hairs at the head, sides, and near the tip of the tail. The general colour is dark grey, spotted with small red tubercles.

The nest-making caterpillars show another form of attacl. Of these, two kinds are especially troublesome in orchards. One is the Small White Ermine, of which the moths are only about three-quarters of an inch in expanse of the fore wings, and are usually livid or whitish, dotted with black, and the hind wings livid or lead-colour. 
The little ashy, dirty yellowish, or lead-coloured caterpillars, spotted with black, spin web-nests, in which they live in great companies, until the leafage all around may be destroyed and hung with the tattered remains of their successively spun webs.

The yellowish or brownish Lackey Moths, with their handsome hairy caterpillars, as much as an inch and a half in length, striped on a grey ground with scarlet or orange, blue, and black, give another example of a common web-nest-forming caterpillar.

These various kinds, including besides what may be called those of common habits, such, that is, as moths which come on the wing to the tree, and of which the caterpillars, after feeding, spin up on the bark, or in any convenient shelter, may be counteracted in some degree by measures based on knowledge of their habits. The webs of those that make nests may be cut off and destroyed with the caterpillars, or (in the case of the Small Ermine Moth) the chrysalids, within them. Cocoons corered with eggs, as in the case of the Common Vapourer Moth, may be searched for and destroyed; and, similarly, the rings of eggs of the March Moth (Fig. 108), and of the Lackey Moth, which resemble them in being laid in a band on twigs, may be got rid of in some degree by careful search, and pruning off the infested twigs where they can be reached. But for the most part these and various other means of prevention or remedy have to be applied, not as broad measures of treatment, but as special measures for each special attack, involving necessarily special outlay. For these reasons, that is, the pressing need which has long been felt of having some lind of application at hand which is cheap and sure in its action, and which can be brought to bear at once, when required, on any or all sorts of Moth-caterpillars together (whatever their various natures or previous histories may have been), and will kill the whole collection of ravaging hordes at once, without damaging the leafage, the experiments 
have been made, which have resulted, in some of our fruit-growing districts, in the successful introduction of the method of spraying caterpillar-infested leafage with Paris-green, which has long been found serviceable in the United States and Canada.

Paris-green, being an aceto-arsenite of copper, and of a poisonous nature, should be used with great care in mixing, and should never be applied to fruit or to vegetables that are used for food. But the quantity to which, in order to be beneficial, it is requisite to limit application in spraying is excessively small, and our English experiences, as well as those on the Continent of America, where Paris-green has been used regularly in farm and orchard prevention for many years, show that with proper care it may be used with perfect safety.**

Other mixtures, such as kerosine or paraffin mixed with soft-soap, may be found useful for the same purpose, though they have not yet been taken up here, and the American plan of "jarring" the branches smartly, so as to cause the caterpillars to fall on straw scattered below, which can afterwards be set on fire and the caterpillars thus destroyed, is an American remedy of old standing. But, with us, with regard to means of sweeping off the hordes of difierent kinds of caterpillars altogether, when they are ravaging in the spring or early summer for some years back, trials have been made, in many isolated

* I have not given the proportions and method of application in the letterpress, because, for safe and effective use, these points, including method of mixing and of delivering the spray, cautions to be observed in use, and many other very practical considerations, must be studied in detail, for which there is not syace in this little book. Those who wish to study them from the beginning will find them in tile Government lieports of the U.S.A. Board of Agriculture, also in the Canadian ofticial returns. The details of the rise and progress of this treatment in this eountry will be found detailed in my 13th, 11th, and 15th lieports on Injurions Insects, 1s. bd. each, Simpkin \& Co., S'tationer's' Hall Court, London, E.C. A short account of all necessary detail, with necessary addresses for supply of material or supply of sprayers, will be found in 'Paris-green, its uses,' \&c., a short pamphlet (same publishers), price '2d., but which I am always happy to forward to all applicants gratuitously. 
cases, of various kinds of treatment, which it was hoped might be of use in lessening this yearly amount of loss ; but, so far as the results of experiments were recorded, they have been of little public benefit.

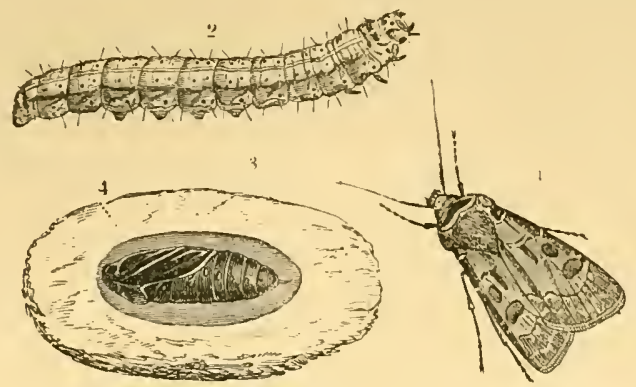

FIG. 111.-Heart and Dart Moth : caterpillar, and chrysalis in earth-cell.

Another very important division (taken agriculturally) is that of the surface caterpillars, so-called from their injurious operations being for the most part carried on near the surface of the ground.

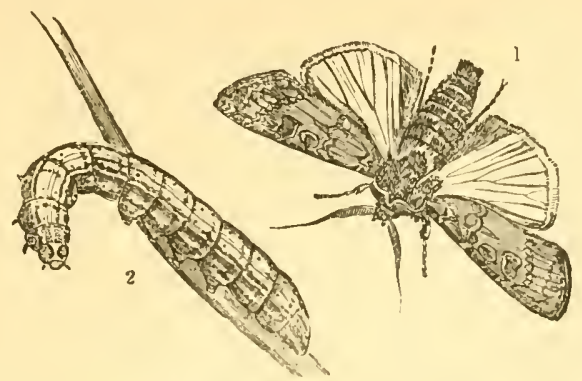

Frg. 112.-Turnip Moth or Common Dart Moth: 1, moth; 2 , caterpillar.

The family of Moths to which these belong is termed Noctuida, from the circumstance of many of them Hying chiefly at night or in the dusk. The Heart and 
Dart Moth (Fig. 111, p. 141), the caterpillar of which is almost as often found at Turnip bulbs as that of the Turnip Moth or Dart Moth (Fig. 112) ; Cabbage Moth (Fig. 113); the great Yellow Underwing (Fig. 4); and some other kinds, the caterpillars of which more or less frequent the surface of the ground, do infinite harm, botl in field and garden. In some cases, like the.Turnip Moth caterpillars, they feed at, or below, the ground-level on almost every common root crop, or corn crop, they can reach; and when the weather is

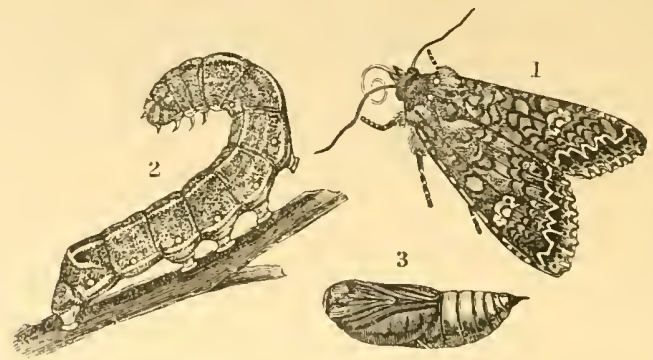

Fig. 113.-Cabbage Moth : caterpillar, and chrysalis.

too severe in winter for them to continue feeding in the Turnip bulbs, they simply go down deeper for a time, and, after coming up again to feed, turn to chrysalids in the ground in the following spring or early summer. Others, like the caterpillars of the Cabbage Moth, feed in the hearted Cabbage, and turn to chrysalids in, or on, the surface of the ground before winter. But whatever slight difference there may be in the habits of these various kinds of thick fleshy caterpillars, about an inch and a half long, which we only too often find either at the roots or on the leaves of the Cabbage and Turnip, this special point of their nsually passing the winter under ground puts them very mucli in our power.

Before the caterpillar turns to the chrysalis, it makes 
a cell in the earth, in which it is protected from wet and sudden changes of temperature, or it seeks or prepares a safe resting-place for its change, or for a time; and so long as the caterpillars are thus protected no amount of cold to which they are here exposed will, as far as we know, do them the least harm. But if they are thrown out of these shelters to the influence of drying winds or hot sunshine, or to lie soddening helplessly on the surface in moist or muddy ground, or to being frozen in these states, then their constitution will not bear it. Tho quote one of our chief American authorities, "It is evident that freezing does not injure the cut-worms" (as these surface caterpillars are called in the States), for nature has prepared them for it; but freezing in connection with loose wet soil will kill the chrysalids as quickly as it will the worm or caterpillar. This is one of the great principles of prevention:-Turn out the insect pest from its natural shelter, when it is in such a condition that it cannot regain it or make a new one. It takes a little observation of the habits of the creature to manage this properly.

If the caterpillars are turned up too soon, that is, either before they are torpid, or before they have changed to the chrysalis, they will simply go down again. If the soil is turned up when they are gone down very deep, they will not be the worse for what has been done above them. Each worker must look a little for himself, for dates and habits differ with climate and other things; but a little careful observation made by turning over the earth, so as to see where the creatures are, will be well repaid. They are quite large enough to be easily seen, if they are in numbers to need attention. This principle may be worked both in winter and summer,- with caterpillars that turn to chrysalids under ground or in cocoons above ground, and with those that frequent leafage of trees or roots of grass, as well as those we have spoken of.

It should always be remembered that when a con- 
course of caterpillars suddenly vanishes (without being cleared off), the creatures are not gone; they have only gone away to change to chrysalids in a safe place, and will reappear presently in a new shape, ready to start a new attack. They will usually be very near their food-plant: grass-feeders will most likely be in the earth beneath the grass; at least they certainly are in the case of the Antler Moth (Chareas graminis), the dark brown and pale striped caterpillars of which feed at the root of pasture grass, and the attacks of
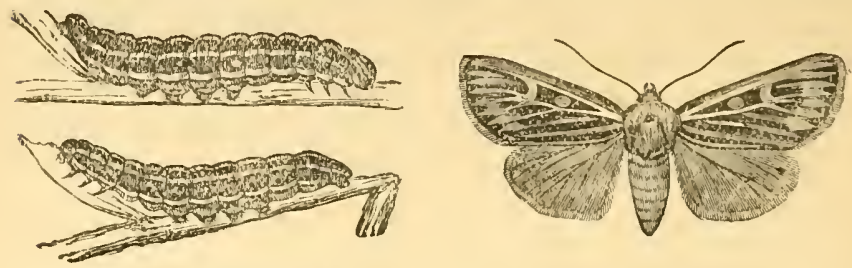

Fig. 114.-Antler Moth or Grass Moth, and caterpillars.

which are remarkable for only occurring occasionally, especially in mountainous districts, and for these appearances being in such vast numbers, and over such a large extent of country, as to be an amazement, and sometimes even the cause of local panic, to those not acquainted with their habits.

The common Cabbage and Turnip surface caterpillars will be found thus (or when time has elapsed for their change to take place), in chrysalis state, on or in the ground near where they fed.

'lhe Beet and Mangold Moth (Silver Y Motlı) caterpillar spins a cocoon on, or not very far from, the plants it infested; and in all these cases, and scores of others, much good may be done by turning up the chrysalids, destroying the weeds they harbour in, and using all other methods of treatment, which a moment's thouglit will suggest, to destroy the pests.

Clearing all weeds that attract the Moths is one method of preventing increase. The constantly in- 
creasing amount of insect attack is in part because of the constantly wider spread of cultivated land. There is much greater amount of special crops, such as special insects feed on ; and instead of there being, as in wild districts, perhaps, one plant in a hundred that may suit the caterpillar, there are districts all through the country where nine-tenths of the growth are its chosen food. If, therefore, in addition to the crop

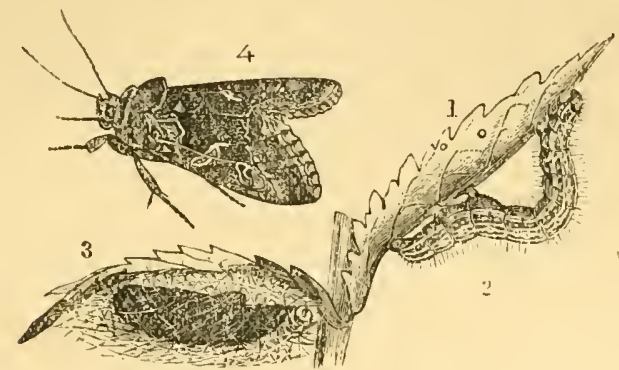

F'IG. 115.-Beet Moth, caterpillar, and chrysalis in cocoon.*

food, we let weed food collect in our borders, we add most needlessly to our troubles; and by clearing and burning these patches round garden and fields we may do a deal of good.

The enormous appetite-or necessity for eating-of some of these great caterpillars may be used as a means of getting rid of them. Where land has been infested with Turnip caterpillar, it has been found that by ploughing and cultivating it so that there is no food, and letting it thus remain for a fortnight, the caterpillars may be starved out, or will go elsewhere.

* It will be observed that this caterpillan is what is sometimes called a " half-looper." Most of the larvæ of the Noctuidie have 16 feet in all, but in some cases the first, and in some the first and second, pair of sucker-feet are absent, and the caterpillar therefore "loops" in walking, though not as much as in the case of the true loopers. 
When attack is bad, the chief thing to trust to is fertilising dressings; but sometimes dressings of gaslime on the land, and on the plants, will check attack to a serviceable extent. This has been found useful in the attack of eaterpillar to hearted Cabbage in the autumn. The gas-lime falls down among the leaves, and thus fills the parts where the caterpillars shelter by day, with what, to a certain extent, keeps them out, and is not pleasing to them.

With regard to hand-picking caterpillars from the roots, it is often said this cannot pay; but it is a regular process in some places where field Cabbage is grown; and on once asking a grower as to it answering, he simply remarked, "If we do not do it we lose our Cabbage." The grubs may be quickly cleared by women turning the soil back at the root of each plant, putting the grub or grubs in a flower-pot, and turning the soil on again. In these kinds of attacks it is quite worth while to reckon on paper the comparative cost of the total or partial loss of crop to be expected, and that of the remedy, and proceed accordingly. Grubs, of the kind we are speaking of now, commouly go on from one plant to another, and cause severe loss, each morning shows the new fallen plants; and the grub will so continue eating till it turns to the chrysalis. But it is easily seen; and once caught we have made a sure cure. This sureness of the cure is the thing to be thought of before trying it. It is often advised to sprinkle lime; but lime slakes very quickly, and, excepting as a manure, does not do nearly the good that is supposed. Dry dressings often entirely fail in effect, becanse they often do not adhere to the caterpillar; and if they do, very likely they do not hurt it.

It has, however, been observed that sudden moisture, especially after hot weather, will destroy Moth or Butterfly caterpillars. They have been recorded by our great authority, John Curtis, as being found, in such circumstances, emptied of their contents, and like mere slins; and in the great attack of Beet Moth 
caterpillars, in 1879, many were thus lilled in Essex.

It was formerly difficult to apply this linowledge practically; but now, looking at the variety of implements which have been recently introduced into this country, suitable for spraying or wushing either orchard tree leafage or that of field crops, there would be no difficulty in experimenting, at least on orchard foliage, as to the effects of cold water in clearing off caterpillar presence.

The treatment for prevention of surface caterpillars may be shortly described thus:-Turn them up by cultivation where land is known to have been infested; and where catch-cropping is practised let the field be cleared of all food at least a fortnight before a new crop is put in; keep up the strength of the crop, but use remedies if you can,--if they will be sure to destroy the grubs.

In a very large number of attacks, it is the worst possible practice to try to work directly on the grubs ; you must counteract their mischief, rather than try to get (literally) hold of them; but with the large Moth srubs, which are often one, instead of a score or hundreds, to a plant, the case is different.

For the same reuson, birds help us much with some linds of Moth caterpillars. They can bore down, and draw out these large grubs, without the broadcast destruction which often follows on their services in searching for Wireworm.

The crow, raven, jackiaw, rook, and partridge, are all said to be of use in clearing away the caterpillars of the Turnip Moth; and in the case of some of the swarms of small caterpillars which attack forest trees, especially the Small Green Oak-leaf Roller (Tortrix viriduna), the flocks of birds which collect when great attack is going forward are our only helpers.

In the preceding pages I have endeavoured to give some idea of the characteristics of the methods of life of some of the chief divisions, agriculturally considered, 
of the order of Lepidoptera (i.e., Moths and Butterflies), and to point out how we may, by acting on these, be sure of not wasting our work in applying methods of prevention and remedy. There are numbers of other.

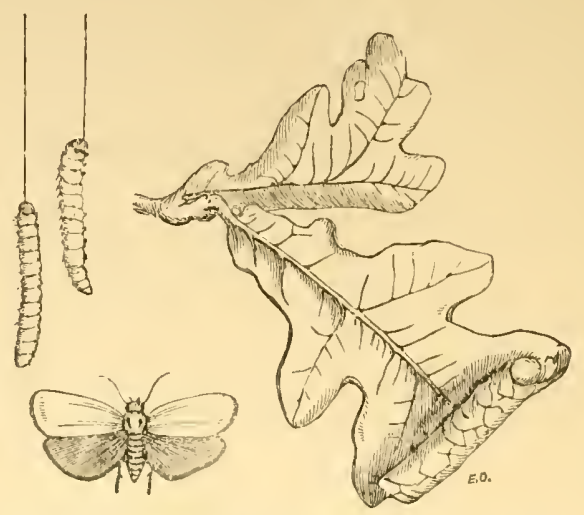

Fig. 116.-Oak-leaf Toller Moth and caterpillars.

classes of attacks, almost countless numbers of individual kinds of attack, which cannot be entered on here, but the principle holds good witl all,--find out the chief points of the life-history; reflect how these can best be met by available (and, if possible, common) agricultural treatment; and having made this ont, let the plan be soundly and thorouglily carried out. Half doing is the cause of much failure. 


\section{CHAPTER VIII.}

SAWFLIES, ICHNEUMON-FLIES, WASPS, dC. (HYMENOPTERA).

Turnip Sawfly, Parasite Maggots; Destruction of Birds; \&c.

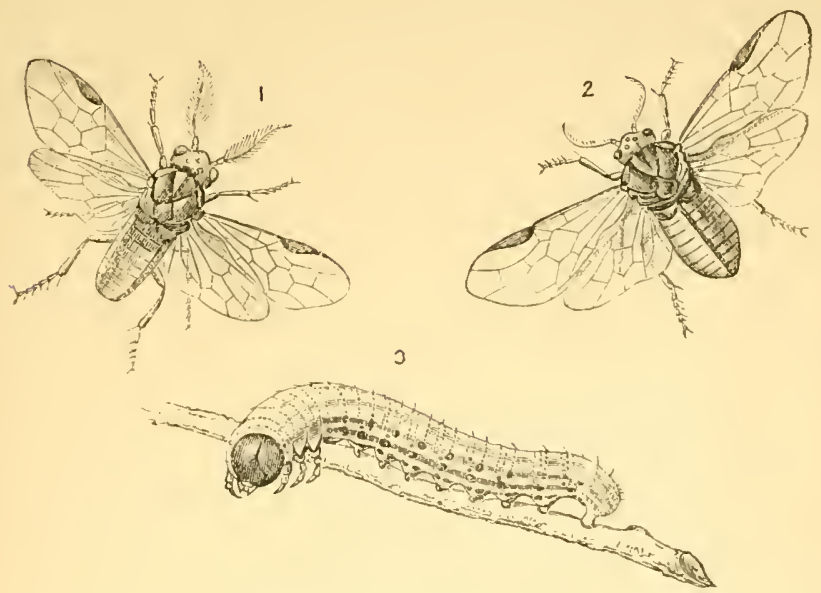

Fig. 117.-Fox-coloured Pine Sawflies (Lophyrus rufus) : 1, male; 2. female, after Prof. IVestwood ; caterpillar, after Dr. Hartig; all much marnified. Nat. size given in descriptions.

In the order which we have just been studying, there is a great likeness throughout, both in the manner of life and in the manner of transformation of all the linds; but in the order which we are now going to study the habits of life of the different families vary very much. 
The first division, that of the Sarflies (Tentheredinidce), is exceedingly hurtful to various crops and trees, by the ravage of its caterpillars to the leaves, or in some cases to the fruit; also, in some cases, by causing Galls. The second division, the Sirexes (Uroceride), feeds for the most part, if not entirely, in the caterpillar state, in timber. A third, that of the Gallflies (Cynipida), inserts its eggs in various parts of plants, thereby giving rise to variously formed gall growths. on leaf or infiorescence, shoot, or stem, or root, of which the bunch of moss-like growth on the wild rose shoots, commonly known as the "Robin's pincushion," and the Marble-gall of the oak, may be taken as examples of most different forms.

A vast number of different kinds of insects of this order, commonly known as "Parasite Flies," and belonging to the families of the Ichneumonide, Chalcidide, and Proctotrupida, help us by inserting their eggs into other insects, in which the parasite grubs feed quietly on the living material, until their hosts sink beneath the task of supporting their unwelcome guests.

Besicles these families, which concern us much agriculturally, there is a large division, including different kinds of Ants, Bees, and Wasps, known by reason of most of them possessing a sting, as the division of Aculeata.*

We need just to observe what the general appearance of the insects of this order is in each of the three stages; but the families which I wish chiefly to be noticed are those of the Sawtlies, which are very injurious, and the Parasite-flies, which are very helpful to us.

We may know the insects of this order, in a general way, by their likeness to common Wasps or Bees. They have two pairs of membranous wings; a mouth, sometimes furnished with short and thick, or with long and narrow, pincer-like jaws (mandibles), as in Wasps 
and Sawflies; and sometimes also with a kind of tongue, suited for collecting moist food, as in the case of the Bee. This trunk (as it is often called) is formed of the feeler-jaws and lower parts of the mouth in $a$ much lengthened condition.

The females have the abdomen supplied with an apparatus which acts in some cases as a sting; in some as a piercer, by which they can insert their eggs into other insects, or wherever they may select; and in some this oripositor (or egg-placing apparatus) is formed of several pieces, acting togetler like a saw, whence one division takes the name of Sawflies. The grubs are for the most part legless (much like the well-known Wasp grubs); but it is important, for practical purposes, to notice that the Sawfly division may, with very few exceptions, be known in the caterpillar state from others of this order, and from all the other kinds of caterpillars which we have noticed, by having a larger number of sucker-feet. (See Fig. 117.)

The Sawfly larvæ, or caterpillars, have three pairs of claw-feet,-like the caterpillars of Butterflies, and of some Beetles; but, with few exceptions, they lave six to eight pairs of sucker-feet. They are often called caterpillars, and much resemble Butterfly caterpillars, both in slape and in being often prettily coloured; but they may (with the exception of the Corn Sawfly, and a few others) be readily known from Butterfly or Moth caterpillars by the larger number of sucker-feet. When there are twenty-two feet in all, that is, counting true claw-feet, sucker-feet under the body, and pair of sucker-feet at the end of the tail, it, will be seen there is only one segment of the body that is legless.

When full-fed the Sawfly caterpillars often go lown into the ground, and many of them spin cocoons; and the change to the chrysalis takes place in a few days in summer: later in the year the caterpillars lie many months unchanged; they may pass through the chrysalis state in a fortnight, or less time. The chrysalis (like most others of this order) is inactive, 
but has the limbs folded beneath it, much in the same way as the Beetle chrysalis.

The shape of the Sawflies is shown by the figures (especially those at p. 149). They may be said to be very like small square-made Wasps, but with the abdomen closely applied to the body, instead of being stalked.

Sawfly caterpillars are most voracious, and they
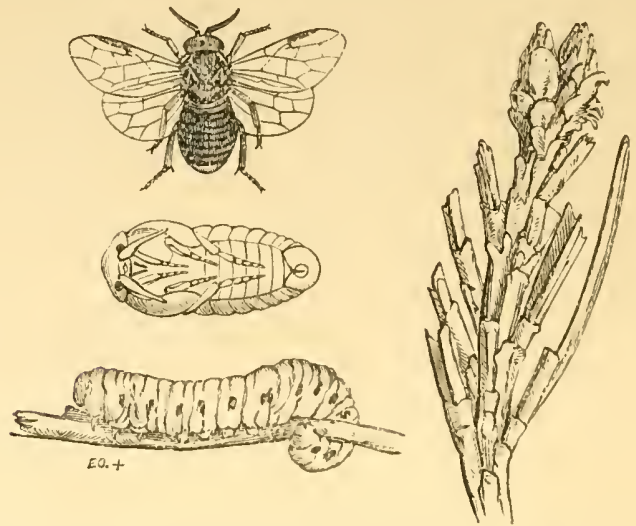

FI. 118.-Pine Sawfly, caterpillar, and pupa; magnified. Pine leaves injured by caterpillars.

are often found together in such vast numbers, on the trees or crops they attack, as to cause serious loss. The Pine Sawfly caterpillar does great damage to Pine plantations or forests in Scotland; the Gooseberry Sawfly is a constantly recurring cause of loss to bush fruit growers, and in these and other cases of Sawfly presence, where the cocoons can be got at beneath the surface, and the infested area is not too large for application of this remedial measure, attacks might be perfectly easily lept in check by utilising the habit of the caterpillars of going down for the winter, and lying in cocoons beneath the branches they have been stripping of their leaves. 
Where Pines have been infested, some of these small oval cocoons may be on the boughs, but most of them will be found beneath the tree, and most likely near the trunk, lying a little below the surface, or amongst the dry leaves or moss, or forest rubbish, sometimes in masses as large as a man's fist. By collecting these, or by collecting the surface soil, or by skimming the rough herbage and heather, and charring it in heaps (taking care of course to go down to the depth at which the cocoons may be found), the amount of the following year's attack may be much lessened.

Exactly the same kind of treatment is the best way of keeping Gooseberry Sawfly caterpillars in check. They winter in cocoons under the bushes; therefore if any trustworthy person will turn over the soil to see the depth at which the little brown cocoons lie, the earth may be scraped away to three or five inches depth, or whatever depth the caterpillar may have gone down to, according to the nature of the soil, and earried array and disposed of, so that when the caterpillar lias turned to the chrysalis, and the chrysalis has turned to the Sawfly, the Sawfly may not be just where it has only to walk or fly (as it may prefer) to the boughs close by to find itself at home in the Gooseberry leaves, and waste all our trouble. This is a point requiring attention. In one of the great fruitgrowing districts, where Gooseberries were grown in acres, I have seen the clearing of the soil from beneath the bushes well attended to, but when scraped out it was left between the rows; and the result was a hearty attack.

These caterpillars sometimes migrate in bodies, and then are completely in our power. If seen crossing a road, or from one field to another, there should not be an instant's delay in destroying them by the readiest means at hand. 'Trampling on them would be a complete cure when they are on the open ground of a road; and (when moving from one field to another) if a couple of men were set to cut a long strip of turf 
off across the line of the advancing army, or beat a line of earth flat with spades, there would be a clear space on which the caterpillars might be seen and crushed (or destroyed in any convenient way) with certainty.

Attack of Apple Sawfly (figured with its caterpillar, life size and magnified) may be taken as an example
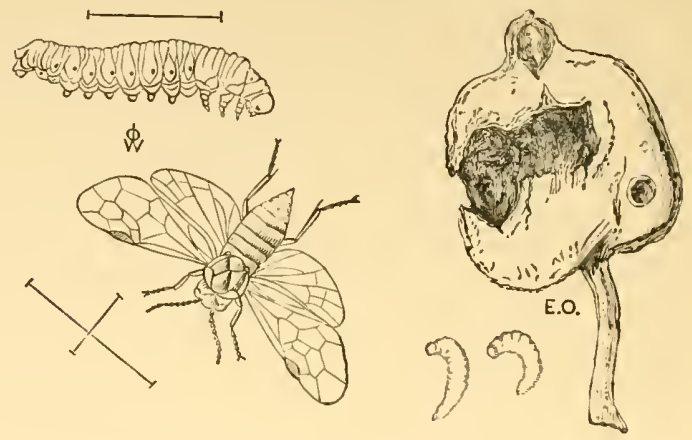

Fig. 119.-Female Sawfly and caterpillar, magnified, with lines showing nat. size, after Prof. J.O. Westwool; caterpillars, nat. size; and infested Apple.

of how easy it is, witlout careful observation, for an infestation, which bears much resemblance to some other lind, to escape requisite notice, $i . e .$, such notice as causes proper measures to be taken, instead of trouble and money being spent to no purpose on applications suited to another attack of which the clurysalis stage is passed in a different locality.

Apple Sawfly presence has long been known of in this country, but so far as I am aware has been little observed, and it was not until last summer (1891) that I had an opportunity of studying the characteristics. In many respects the attack of these caterpillars to the Apple fruit much resembles that of the too well-lnown Codlin Moth caterpillars. It may, howerer, be certainly distinguished by the Sawty 
caterpillar having a greater number of sucker-feet beneath the body, that is, six pairs (see Fig. 119), which, with the pair at the end of the tail, and the three pairs of claw-feet, make in all twenty. There is the further characteristic of the caterpillars possessing a most unpleasant bug-like smell. Thus they may be distinguished from the Codlin Moth caterpillar, the larva of the Carpocapsa pomonella.

With regard to methods of prevention; in the case of either of the attacks it is desirable to gather up and destroy prematurely fallen Apples, which from their bored and injured state show that they have fallen from caterpillar presence within, and may therefore very likely be then infested. But beyond this, the chief means of prevention are on quite different principles. The Codlin Moth caterpillar (to a great extent), after leaving the little Apples, creeps up the trees, and changes to the chrysalis state in crevices of the bark. The Sawfly caterpillar, on the contrary, goes down into the ground to form its cocoons. It is therefore needless to point out that any amount of scraping, washing, and cleaning the bark is merely money thrown away, if all the while the enemies against whom these operations are directed are lying from two to six inches under the surface of the neighbouring ground.

The Turnip Sawfly (Athalia spinarum) sometimes causes overwhelming mischief; but this is not a regular yearly attack, by reason of rotation of crops; and also because in regular course of autumn cultivation the cocoons are thrown up, or buried beneath their natural resting-places.

The progress of the injury is very rapid. The bright orange Sawflies lay their eggs in slits sawn in the leaves. One female will lay over two hundred eggs. The eggs hatch in about five days; the time varies with the state of the weather; if warm and favourable, they will hatch sooner. The twenty-twofooted grubs are greenish at first, then black, then slaty, and are full-grown in about three weeks, during 
which time they eat voraciously. They go down into the ground to change, and the new brood of Sawflies in summer comes up, ready to lay eggs and start a new attack in about three weeks. With this attack we can, as with most others, do something by ensuring vigorous plant growth; but all methods that have been found useful to check attack will be found to be based on the special habits of the caterpillar.

During its three weeks' life it changes its skin about

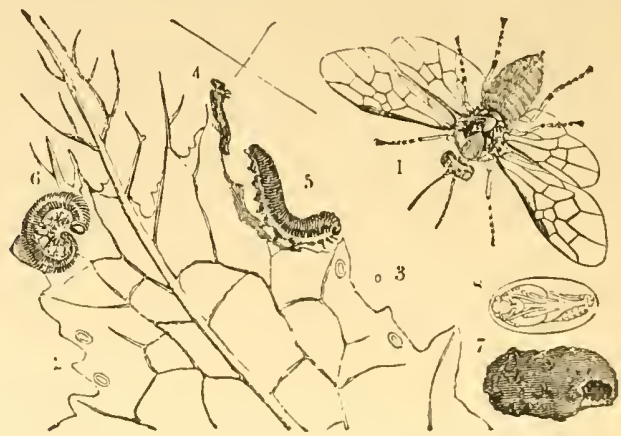

FrG. 120.-Turnip Sawfly, magnified; caterpillar, pupa, and pupa-case.

once a week, and to manage this it must hold fast, by means of the pair of sucker-feet at the end of its tail, to a leaf or stem, so as to liave something to drag against in the struggle to get free of its cast coat. If it camnot do this it dies. Also it has only the power of spinning a thread to let itself down, or come home again by in passing alarms, during the first few days of its life. After that, if it fills to the ground, it can only return by crawling.

The remedies which are chiefly used all turn directly on these habits. The plan of driving sheep through an infested field, or of brushing the plants with boughs, either carried by hand or fixed on a scuffler; or, again, dragging a cart-rope over the plants;-all turn 
on endeavouring to make the caterpillars loose their hold, which we see amounts, with a large proportion, to the same thing as lilling them outright.

As in the case of Turnip Flea Beetle, various kinds of dressings may be of use, such as lime, \&c., if applied so that they stick to the insect and leafage ; and also all measures to keep the earth moist enough to rum on a good crop, and keep the Sawfly from en-

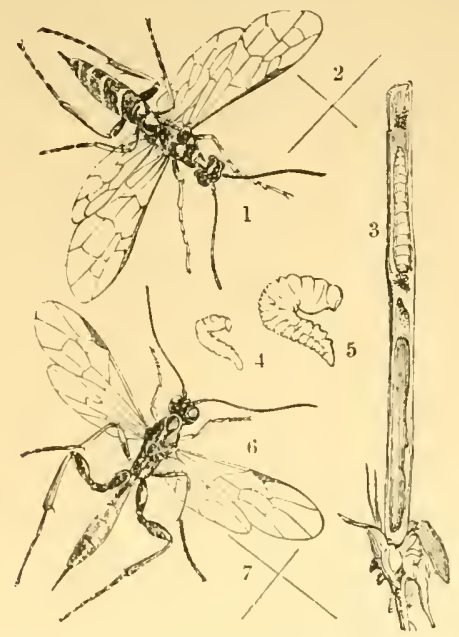

Fig, 121.-1-5, Corn Sawfly and grub, natural size and magnified; 6 and 7, Parasite Ichneumon Fly, marnified and nat. size.

joyment of the full light, heat, and drought, in which it delights, will be of serrice.

There is one other kind to be noticed, because it differs greatly from those just named in its habits. It is the Corn Sawfly (Cephus pygmans), which feeds more especially within the Wheat stalks; and its presence may be partially known by the blasted ear.

This whitish maggot has only the rudiments of the three pairs of claw-feet; and when its work of mischief 
to us is done, it rests for the winter in a silken case, very near ground-level, in the sawn-through stalk. To prevent attack recurring, it is a perfect treatment to gather together the infested stubble and burn it.

This is an exception to the usual form of life and place of change of Sawfly larvre, therefore must be treated differently; but there is the same principle to be followed as with caterpillars and chrysalids of other kinds of Sawflies, and also of Butterflies and Moths, that is, firstly, to find out where they pass the winter, and then to turn them out from their shelters.
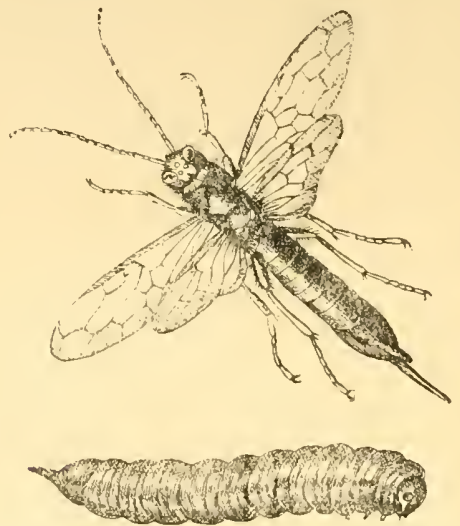

FIG. 122.-The "Common" Sirex and grub.

The amount of injury caused by Sawfly caterpillars, and especially from time to time by those of the Turnip Sawfly, is so serious that a great deal (of more or less use) has been written on the subject; but in the short notes of the five linds of attack mentioned above, it will be seen that whether as infesters of the forest tree or the garden fruit bush; as feeders within the firm fruit of the Apple, or on the succulent leaves of the 'Turnip, or carrying on their injurious works hidden within the growing Wheat-straw; or, again, 
whether the larvæ or caterpillars are possessed of 22 feet or 20 feet, or (for practical purposes) of no feet at all, there is one method of prevention applicable to them all,-to turn out the cocoons and destroy them.

The "Giant," and the "Steel-blue" or "Common" Sirex, may be taken as examples of the family of the Uroceride, which sometimes do great harm by means of the galleries gnawed by their large grubs in solid tiunber.

The Sirex gigas (or "Giant Sirex") is a splendid insect, as large as, or larger than, the Sivex juvencus (Fig. 122), and of a rich yellow colour banded with black.
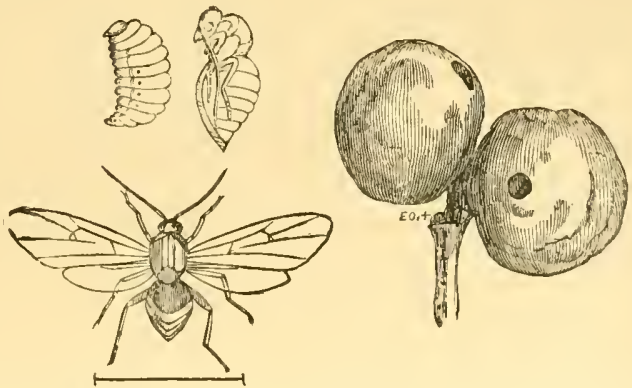

Fig. 123.-Marble Galls. Gall Fly, grub, and pupa; magnified.

The family of the Gall Flies (Cynipidce) is also one which is not of much importance agriculturally, but it may perhaps be convenient just to mention.

The female Gall-fly has a lind of pointed tube, or arrangement of bristles, by means of which she is able to insert her egg or eggs into whatever part of the plant she chooses for the purpose. In consequence of this, various growths form, such as the Oak Marble Gall; the Oak-apple; or the Spangles of the Oak-leaf; or the bright green and red moss-like bunch, which we lnow as the Pobin's Pincushion of the Rose; - and within these the legless maggots hatch, feed, change to chrysalids, and in due time from them they cmerge 
as Gall-flies, more or less resembling the one figured; but they are not mentioned for special attention now, but merely to notice their existence.

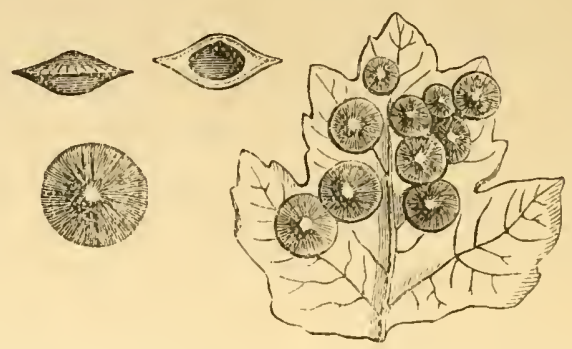

FIG. 124.-Spangle-galls on Oak-leaf; ditto, magnified.

The families of the Parasite Wasp-flies are important to us, as a means of keeping the increase of other insects in check.

One division of these is that of the Ichneumon Flies (Ichneumonide). These are much like the Ichneumon parasite of the Corn Sawfly. They are lightly-made insects, with a longish body and abdomen ; long legs; a small head with long horns, often having a ring of white on them; and an ovipositor, sometimes short, sometimes long, and often permanently extended like a large and long sting. With this they insert their eggs, for the most part into the grubs of other insects, but sometimes into their eggs, and occasionally into the chrysalids; and those linds furnished with long ovipositors pierce with them through bark or solid wood, and thus insert their eggs into Beetle grubs, or whatever their selected victim may be, which, although out of sight, their instinct tells them is within, ready to act as food to their maggots; and thus they give us help which nothing else affords.

In the case of Corn-ears which are infested by Aplides, many of the Aphides, instead of being of the 
natural colour, green or yellow, or brown or other tints, will be seen to be of a rich brown, or almost black. These have been killed by the Ichneumon. The female of the Aphidius (see Fig. 125: 5,6) inserts a single egg into the abdomen of many Aphides, one

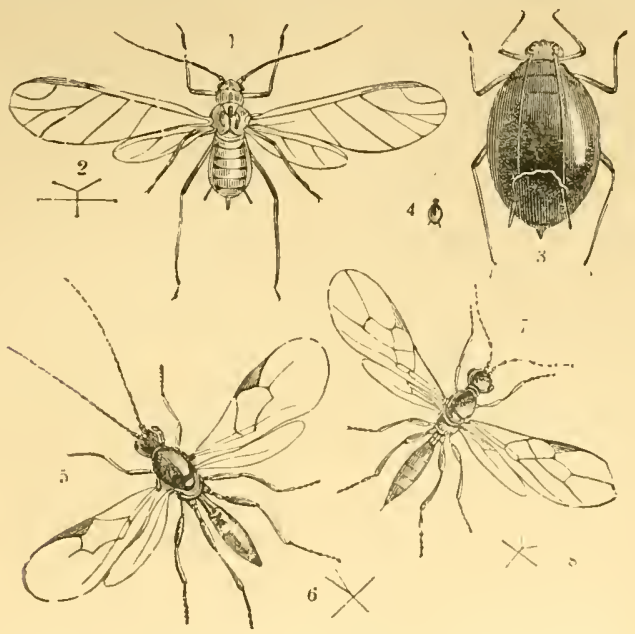

FIG. 125.-1 and 2, Corn Aphis; 3 and 4, wingless infested specimen; 5-8, Parasite Ichneumon Flies; all magnified, with nat. size.

after the other, and the maggot, which hatches from the egg, consumes all that is eatable, until its live host is reduced to a state which will not carry on life any longer. Its uninvited guest goes through its changes within to an Ichneumon Fly, and presently quits the hardened skin, which is distinguished, as we just observed, by its colour. Sometimes every Aphis on a Corn-ear is thus destroyed, and there are other kinds of allied Parasite Flies which help us similarly.

One of the forms of attack which is the plainest to be seen is that of the Cabbage Ichneumon Fly (Microgaster glomeratus). This little Fly lays a vast 
number of eggs, sometimes more than sixty, in one caterpillar of the large Cabbage Butterfly. Here the maggots hatch and feed, avoiding by instinct such parts as the consumption of would be a fatal loss, firstly, to the host, consequently to the guest. The containing caterpillar-the live food, that is-meanwhile feeds and grows, not only until it attains its full size, but it may often be known from uninfested ones by its swollen appearance. It has not, however, power to turn to the chrysalis state: when the time for this comes, the maggots within pierce its slin, and each one spins for itself a small cocoon of yellow silk, in which it goes through its changes to the complete insect by the side of the dead body of the exhausted caterpillar. These little Ichneumon Flies are one of our protections against great increase of the caterpillars, and the small sillien cocoons, which are easily seen when they lie together in masses on Cabbage leaves, should never be destroyed.

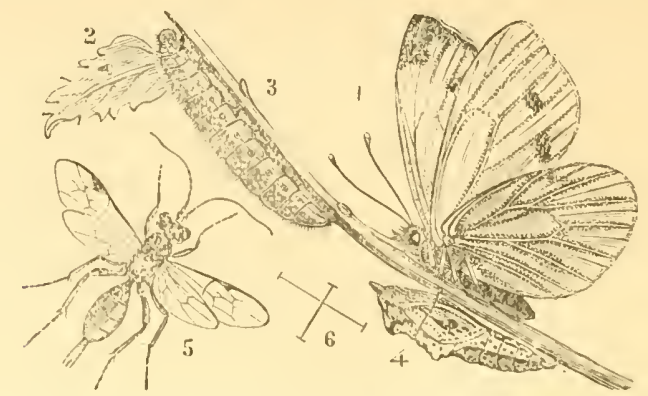

FIG. 126.-1-1, Gireen-veined White Butterfly ; 5 and 6 , Ichneumon

Fly (Hemiteles melanarius), magnified, with nat. size.

Another kind of small Ichneumon Fly (ITemiteles melanarius) preys in the same way, by means of its maggots, inside the chrysalicls of the Green-veined Cabluge Butterfly. These infested chrysalids may be linown by their dark brown colour, and slould never be destroyed, as each one is a case-a pacliage, so to say-full of checks to a troublesome crop-preyer. 
It will be noticed that these Ichneumon Flies are all very mich alike in shape, and that their wings are much veined.

The Parasite Wasp-flies of the two other families, which are most important to us (Chalcididce and Proctotrupidce), are for the most part very small, with almost, or quite, veinless wings.

The Pteromalus puparum (Fig. 127, magnified, one of the Chalcidide) is one of the kinds which destroy chrysalids of the Large and Small Cabbage Butterflies. This very small Fly is stated to lay its eggs on the outside of the chrysalis, as soon as it has cast off its caterpillar skin, and is still soft and tender. The maggots from these eggs soon hatch and eat into the chrysalis, and sometimes as many as from two hundred to three hundred live thus in one chrysalis, where they change to the perfect Parasite Fly, and

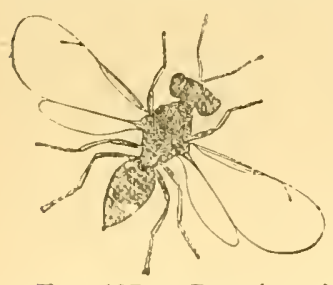

FIti. 127. - Parasite of chrysalis of Cabbage Buttertlies, magnified. come out soon in summer to continue the useful rork. In winter some remain in the chrysalis.

The use of these Pteromati is well shown by their work in North America, in cheching increase of Cabbage Butterfly.

The Small White Cabbage Butterfly made its appearance (or at least was first observed there) at Quebec about 1859, and gradually spread and caused much damage, but for several years no Parasite appeared to check it. In 1871 -that is, about trielre years after the appearance of the Butterfly -it was announced that the Parasite we are now spealing of had appeared: the British Parasite had followed the British Buttertly, and was koing its appointed work. In 1875 it (the Parasite) had become quite common in the State of New York; and later on it was obscrved to be still on the increase.

'I'he great benefit gained by natural helpers of this 
kind has caused it to be suggested that we should rear them. This matter seems rather hard to manage; also we do not often benefit much by upsetting the regular balance appointed; but it is often in our power to follow up a hint of this kind, by remembering.

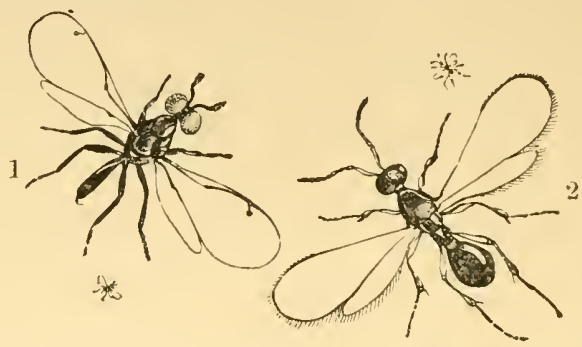

Frg. 128.-Parasite Flies of Wheat Midge maggot, nat. size and magnified.

that when an out-of-the-way insect enemy has appeared, we may very likely be able also to introduce. its regular check, and leave the results to follow in due course.

Sometimes also a new infestation may be traced home to the country from which it came by means of its accompanying Parasites. In the memorable appearance of the Hessian Fly in this country, we had no clue to lead us to the knowledge of whether it had come from America or from the Continent of Europe, until examination of its parasites showed that, with the exception of one lind common to both Continents, the others were not American, but Russian.

The Parasite Flies of Wheat Midge (fignred) show the shape of two other linds of these minute Flies. The Mucroglenes, of the family of the Chalcidide (Fig. 128: 1), is supposed, from its habits, to destroy the Midge-grubs; and the Platygaster, of the family of the I'rortotrupide (Fig. 128:2), has been watched in its operations of laying one egg in each Midgegrub it attacks. 
There are other kinds of Parasites of nearly-allied kinds, which we have not space to enter on here; but the general principle of preserving a useful amount of them is so important that, though it is a very difficult matter to protect them, it is as well to be careful about setting on foot regular measures calculated to lessen their numbers.

It may be doubted whether, in regard to help from parasitic insects, we do not suffer, rather than benefit as much as is supposed, by great encouragement of birds. TVe cannot tell accurately what amount of the small Parasite Flies are taken as bird food, for their small bodies are probably soon digested; but it appears reasonable to suppose that as we know some birds take them, others also do so, and in this way do the reverse of helping. I would not for an instant suggest clearing away birds; but it would be well to bear in mind that the works of creation are founded on a principle of order, and of relationship of one part on another; and if we use such power as we may have to alter any detail, we are likely to suffer. We have altered the amount of food for insects by the enormous necessary increase in food crops; but it appears to me that to try to keep these insects in check by calling in bird-help in legions,which grub up the plants to be protected, and eat up the eaters of the insect foes, and likewise (when insect food fails the many months) betake them to the Wheat-ears, - is very much like bringing in the rats to drive out the mice.

The families of Wasps, Bees, and Ants are included in another great section of this order, called the Aculeata, because they, or most of them, are furnished with a sting, much resembling in appearance, and pain of application, a needle; known in Latin as Acus.

These have been written on for so many years that we need not enter on them at length; but it is well to observe that the Hive Bees, the social Wasps, and 
social Ants, are remarkable for much of the work of the community being carried on neither by the males, nor as a regular thing by the large females, which.

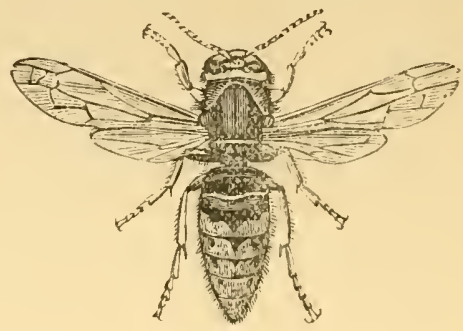

Fic. 129.-Hornet.

are commonly known as queens, but by a large body of abortive females, or neuters, commonly known as "workers."

In the case of the Queen Bee, we have a clear instance of the way in which different food and accommodation acts in altering, or rather in fully developing, the porrers; and gain matter for thought, at least, that a precisely contrary treatment, such as compressing, starving, chilling, \&c., brought about by common farming measures, will not (or probably may not) be without effect in stunting the growtli, and otherwise lessening attack.

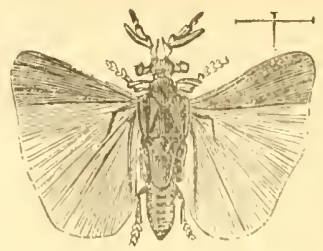

Fig. 130.-Bee Parasite.

These aculeatc Hymenoptera, howerer, are little included in the special points of farm-insect study under consideration, and for the same reason the 
three following orders need little more than just mention of their names.

These are the order Neuroptera, in which are included the Dragon-flies, May-flies, and others, amongst which are several kinds of great service in destroying Aphides. For figure of one species, see that of Chrysopa perla, or Golden-eye, p. 34.

The order of Strepsiptera, or "Bee Parasites," is almost microscopic, and is distinguished by the fore pair of wings being merely represented by twisted appendages.

The order of Trichoptera, or Caddis-flies, spend their maggot-life commonly in cases formed of shells,

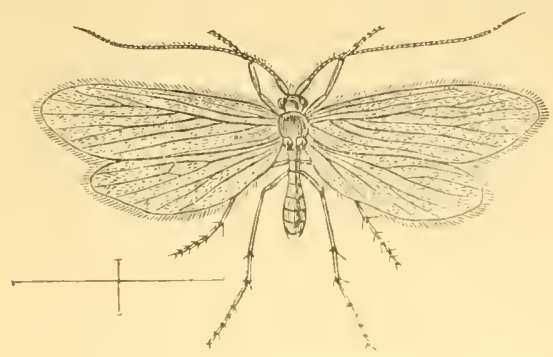

FIG. 131.-Caddis Fly.

or bits of stick, or little stones, or, in fact, of anything available, which they can spin together, in our ponds or streams.

The student will observe that the five order's, which we have considered at some length, have one great point in common: they are all quite different in the first state (as grubs) to what they are in the second (as chrysalids), and to what tlrey are as perfect insects; also that in the chrysalis state, even if the limbs are visible, still they are not able to use them; and thus we have one clear season for measures of prevention, which it is well to make the most of.

Further, that each one of these orders-the Flies, 
the Fleas, the Beetles, the Moths, and the Sawflies and Parasite Flies-have for the most part a regular shape for the grub, chrysalis, and perfect insect, by which you may know them from those of other orders. You may know a Fly-grub, chrysalis, and perfect Fly, with certainty, from a Beetle-grub, chrysalis, and perfect Beetle. We have seen that the grubs may be known for the most part by the absence, or by the number, of feet or sucker-feet; the chrysalids by being in cases, or in a skin of thin cement, or by the limbs being visible; and the perfect insects are easily known. There is a difficulty about some of the chrysalids of the Wasp tribe resembling the Beetles, but this is rather a scientific than a practical matter, for the place you find them in often shows what they are.

The remainder of the orders of insects which we have to consider are much more easily known, because from the time they begin their life they are so like the parent insect in everything, excepting the absence of wings, that they commonly go by the same name. 


\section{CHAPTER IX.}

APHIDES, SCALE INSECTS, PLANTBUGS,* \&c.

(HOMOPTERA.)

Froghoppers; Hop \& Turnip Aphis, \&c.; Apple SCALE.

( $H E T E R O P T E R A$.)

Pilant-Bugs.
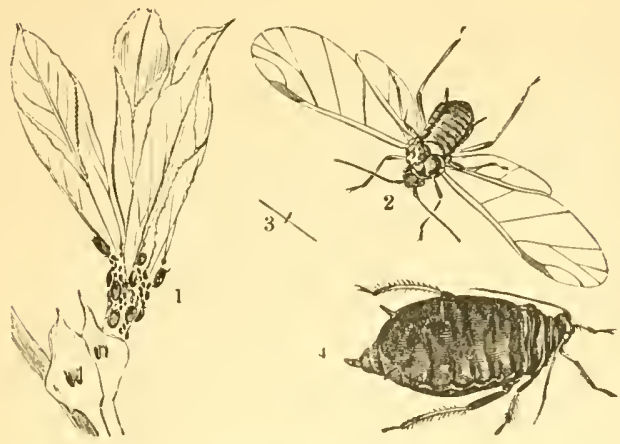

Fig. 132.-Bean Aphis: 1, infested Bean shoot; 2 and 3, male, nat. size and magnified; 4 , female.

Of the five orders which remain, and which have not as yet been noticed in detail, it will, perhaps, be best only to enter at any length on the one which

* Short notices also of Orthoptera (Locusts); Euplexoptera, Earwigs; Thysanoptera, Thrips. 
includes the Aphides and Scale Insects, with merely a slight mention of the four other orders, which are much less important to us in this country. If we try to give more than just a mention of these, it will in this short space be more confusing than useful.

These four less important orders consist of the Heteroptera, or Plant-bugs; the Orthoptera, which includes the Cockroaches, Mole Crickets, House and Field Crickets, Locusts, and Grasshoppers; the Euplexoptera, consisting of the Earwigs; and the Thysanoptera, commonly known as Thrips.

The insects of these orders, as well as most of those of the order of Homoptera, which includes the Aphides, commonly* change so little in appearance during their lives, that from the beginning of it they may be known by their likeness to the parent insect, and usually are called by the same name. The chief difference is that at first they hare no wings : if you will talie a dead Grasshopper and pull off its two pairs of wings, you will see that, t excepting in size, it is very like the newly-hatched wingless ones, which we should call larre, if we want to describe them scientifically. This first stage, withont any wings, answers to that of the grub, or caterpillar, or maggot, in the orders we have noticed. During this stage the insects eat and grow, and moult their skins, just as caterpillars do. As time goes on the wings begin to grow ; and when the monlt of the slin shows this is taking place, then they are in the second stage, which answers to that of the chrysalis. Like the chrysalis of the Beetle or the Moth, the wings are forming; but, unlike it, the legs are in a state to use, and commonly are uscd actively; the mouth also, be it of jaws or a sucker, is in working order, and very fully employed.

* There are some exceptions, as with the Coccidce, or Scale Inscets, and the Aleyrodida, or Snowy Flies.

† Sce Figs. of Locust, p. 31; Locust larva, p. 11 ; and Mole Cricket anil larva, p. 192; all of which belong to the same order as Grasshoppers, namely, Orthoptera. 
When the insect is perfect within, it moults again, and appears with the full amount of limbs, and all the powers to which it ever attains.

A description of the method of change-that is, of the whole operation of moulting from the commencement up to the insect stepping out of its cast clothing and standing perfect, besides its almost precise counterpart-will be found at pp. 21, 22.

It is useful to know exactly how this change occurs, - to see it for onrselves, and to be able to show it to others,-because, though the little wingless insect vermin may be doing no great harm, as a few here and a few there, yet they will grow bigger presently; they will by no means give us a season of peace in the middle of their lives, and afterwards they will be able to lay eggs, and will multiply. It is, therefore, well to know and to be able to show that the little creature we hardly see is the same that will by-and-bye (if it is, say, an Aphis here, or a Locust in warmer countries) cause broadcast loss and trouble.

The order of the Homopter a, " similar-winged," which includes, amongst the especially injurions kinds, the great family of the Aphides or Plant-lice, takes its name from the four wings being similar, that is, membranous; whereas in the very nearly allied order of Heteroptera, or dissimilar-winged, there is a thick coriaceous or leather-like patch at the base of the fore wings. They do not feed by biting, but by suction. The upper and under pairs of jaws are lengthened into long bristle-like growths, and enclosed in the lengthened lower lip. The whole apparatus forms a kind of beak, by means of which the insect pierces the soft parts of the plants on which it feeds, and draws out the juices. 'Thus it not only hurts the plant by sncking away the sap, but also does great harm by the number of little holes which it pierces in whatever part it attacks.

The insects of this order differ widely in form ; from that of the Scale Insect, fixed like an oyster- or mus- 
sel-shell on the bark, to the Cuckoo Froghopper, springing in its headlong leaps, with its long legs trailing far behind it; and an idea of their appearance will be given much more clearly by figures than descriptions. Some, also, are so much alike in their first :stages, that it is of use to observe that, as in the order of Beetles, the chief scctions are classed by the number of joints of the feet.

The Froghoppers or Cuckoo Flies, some of which are very hurtful to Hops, are amongst the first section, with three-jointed feet. Trimera.

The Apliides or Plant-lice; the Psyllide, sometimes linown as Jumping Plant-lice; and the small Snowy Flies (Aleyrodes), which do a good deal of harm to Cabbage;-belong to the second section, with twojointed feet. Dimera.

The Scale Insects (Coccidce) are the third section; these have feet with only one joint. Monomera.

In the first section (the Trimera) the insects which concern us the most are the Froghoppers. These live in all their stages, as far as their history is known, by driving their beak into the attacked plant, and sucking out the juices. One well-known kind is the Cuckoospit, as it is called, which is to be found, in its two first stages, on many plants, in a mass of froth which it has caused. It is said sometimes to do a great deal of harm; but I have found that merely giving the attacked plant a hard watering, from overhead, easily cleared off both the froth and insect; and if this attack should occur, the mere application of a good quantity of water by means of large garden-engines, such as are used in Hop grounds, would probably get rid of it at once.

Another kind of Froghopper, known as Jumper or Cuckoo Fly, does a great deal of harm in some years to Hops. 'This is of a yellow colour, beautifully marked with brown; but to get a hold on it we need to know where the eggs are laid from which it hatches. A nearly-allied kind is stated to lay its eggs in autumn, 
either on the surface of the ground amongst Grass, or amongst roots just below the surface. Another kind is stated to lay its eggs, by means of its ovipositor, in soft shoots.

This is an example of how thoroughly we need to know the whole history of an insect to be able to keep it in check by reliable measures at a paying rate.

Meanwhile, in this case much is done, when it appears, by taking advantage of such of its habits as

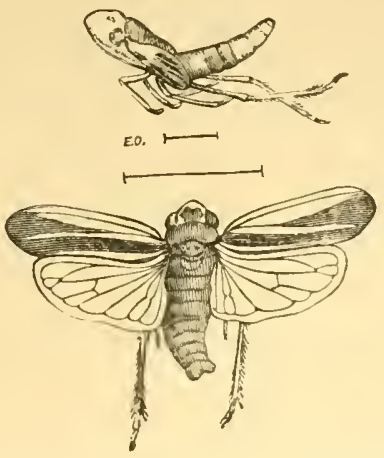

FIG. 133.-Hop Frog Fly and laıva; magnified, with nat. size.

are plainly to be seen. Trays about six feet long, made of iron, are provided, well smeared with tar, and one placed on each side of the Hop hill. The bines are shaken, and the Cuckoo Flies either fall or take their leaps for safety, and light on the tar, which promptly kills them.

The green Frog Fly of the Potato is another example of the same kind of insects, and I repeat the figure to show the partly developed wings in the state that answers to the pupa in this section of the Trimera (see Fig. 134, on next page).

The section of the Dimera (those which have twojointed tarsi) comprises the l'syllicle, Aphide, and Aleyrodide. 
The kind figured (Fig. 135) are sometimes mischievous in this country, but they scarcely require mention. They are very minute insects; their general colour during most of their lives is Apple-green, varied in the

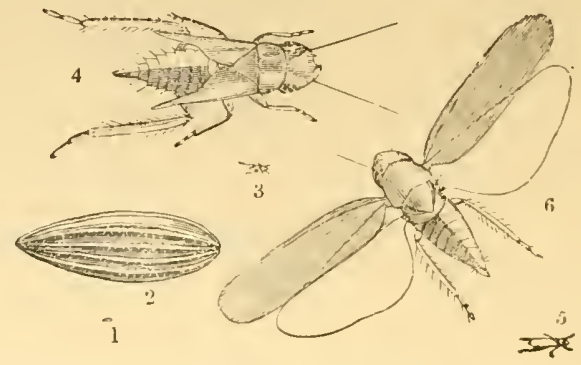

FIG. 134.-Potato Frog Flies: 1, 2, eggs ; 3, 4, pupæ ; 5, 6, Frog Flies : nat. size and magnified.

mature insect, in autumn, with different tints, especially of red. They are chiefly injurious by sucking

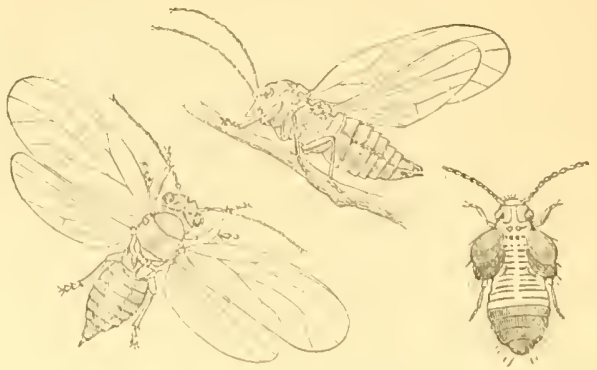

Fin. 135.-1'sylla mali; pupa of P. pysri; Apple-suckers, from life, with wings expanded, and also raised as in the aet of taking flight; nat. length one-twelfth of an inch. P'upa of l'ear-sucker, magr., after Prof. W. Siaunder's.

away the juices of the young Apple-buds, or stalks of the blossoms, or blossom buds.

The most important family in this order, however, 
is that of the Aphides, or Plant-lice. We know their general appearance well on Roses and Hops, Beans or Cabbage; and there seems to be hardly a forest, or fruit tree, or crop plant in this country, of which we can say that it is not infested by one or more kinds of Aphides, either above or under ground.

We know Aphides, in a general way, as small soft insects, having a head furnished with a beak, which

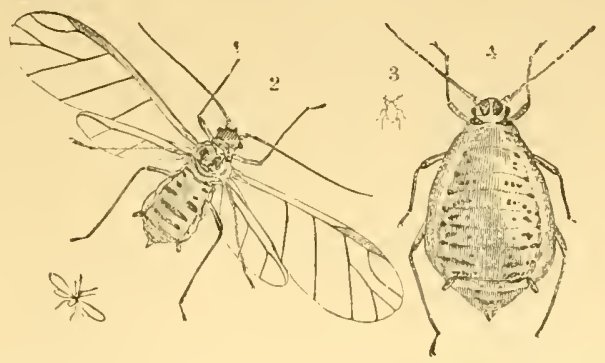

FIg. 136.-Cabbage Aphis: 1 and 2, male ; 3 and 4, wingless female; nat. size and magnified.

is often half as long as the body, sometimes quite as long, or longer; the horns are commonly long and thread-liké. The abdomen ends in a sharp, or curved, or variously formed tip, and often, but not always, bears on its upper part, near the end, a pair of hornlike tubercles, long or short, as the case may be. These tubercles are really hollow tubes, known as cornicles; what their use may be is not clearly known. Some hare considered them part of the breathing apparatus; but, from the most recent and careful observations published, they appenr to be additional means of excreting tluid.

The Aphis larvie, sometimes known as lice, are much like their parent, only wingless; the pupæ have the beginnings of wings. In the perfect state-that is, where there is the fullest amount of developmentthere are males, and winged and also wingless females; 
but in some cases the male has not yet been observed, and sometimes there are only wingless females; likewise in some cases, as with the Phylloxera vastatrix of the Vine, there is a variety of form between the kind that lives under ground on the roots, and above on the shoots or leafage.

There is so much difficulty in the study of Aphides, and often such unnecessary trouble and confusion of mind as to what we need to know for practical use, that before going on I wish to direct attention to a few points which may be of practical assistance.

There is one large tribe of Aphides (such as we know, on the Hop, Turnip, Plum, \&c.) containing upwards of 150 British species. There are also four very much smaller tribes, which live in various ways. Three of these may often be known by the kind of diseased growths they cause, such as the American Blight of the Apple, the swollen bag-like leaves of the Elm, or the Pine Apple-like Galls of the Spruce Fir ; and one of the tribes feeds on roots under ground.

The first four of these five families may be known by a difference in the veining of the wings; and the fifth, which is a root-feeder, by never having (so far as I am aware is known at present) any wings at all.

If we look at the foremost wings of an Aphis, we shall see that there is one

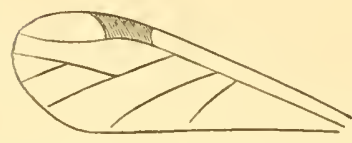

Frg. 137.-Fore wing of Aphis, of division of Aplidine. strong nerve or vein rums down it, near the fiont edge. If we now begin at the body, and count the side nerves that start from this front nerve, - one, two, three, we shall find at the third nerve that, in the Turnip, Hop, Bean, or many other's of our erop Aphides, this third nerve branches again in to two forks.

All Aphides with these two forks to the third nerre belong to one great tribe, known as Aphidince, and have (as far as we can tell from those that have been studied) the same lind of life-history. 
The second tribe has this nerve once forked. This includes only seven species, and the American Blight Aphis, Schizoneura lanigera, is an example of it. This is known as the Schizoneruince.

The third tribe has the nerve not forked at all. There are ten species of this: the Lettuce-root Aplis (Pemphigus lactucarius) is one ; but it is not very important agriculturally. This division is known as the Pemphigince.

The fourth tribe (the Chermesince) has not got this nerve. There are only eight species : the Pine Apple Gall Aphis of the Spruce Fir (Chermes abietis), and perhaps the Phylloxera of the Vine, belong to this division.

The fifth tribe (the Rhyzobiince) is wingless, and found chiefly at the roots of Grass or Corn.

Thus it will be seen that with some few exceptions, which we need not enter into here, there are clear guiding marks through the perplexities of Aphis arrangement.*

It has been well said, "Differences in structure show differences in habits;" and where we can lay our hands on some simple points like this, by which we can sort a mass of confusion into five well-marked divisions, it is well worth while to master the detail.

The life-history of the chief division-the Aphidince, with the two-forked nerre, those which chiefly frequent our crops-may be given generally thus:-'The wingless females, which are produced very soon after the males in autumn, lay eggs; sometimes singly, sometimes in clusters. From these eggs, in the following spring (or possibly before), young Aphicles hatch, which are all females : they go quickly through their changes up to the perfect state, and then they produce living young, which also are all females. These

- Such as are interested in making a thorough study of Aphis life are referred to 'British $A$ phides,' by G. B. Buckton, F.R.S., \& vols., published by the Ray Society; a long and valuable work, which places the subject in a form which can be understood. 
successive generations of living young, still all females, some of which are winged, some wingless, go on, until, in autumn, the last generation occurs, which is of males as well as females; and the females of this, as we said before, instead of producing living young, produce eggs, which start the next year's attack.

This is a general sketch of the history of the great tribe of Aplidince. This tribe includes the Corn Aphis (A. granaria), which infests the young stems of Corn and the growing Wheat-ears (see Fig. 125); the Green Dolphin, as it is called, of the Peas; the Collier of the Beans (see Fig. 132); the Hop Aphis (Fig. 139), which in 1882 caused a loss of more than a million and a half pounds sterling to this country;

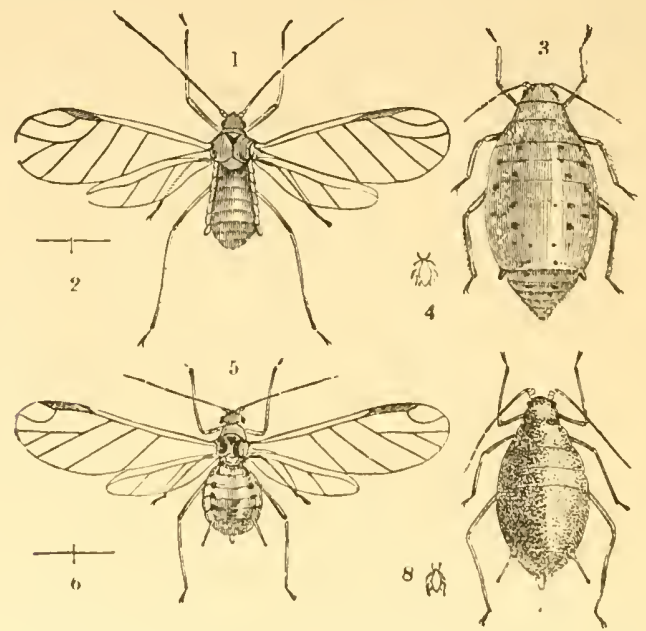

FIG. 138.-Turnip Aphides : $1,2,5,6$, males ; 3, 4, 7, 8, females ; magnified, and nat. size.

the Turnip and Cabbage Aphides; the Black Cherrytree Apliis; and many other kinds too numerous to name at present; besides the white cottony Aphis of the Beech, and the genus lnown as Pine Aphides, 
some of which are cottony, and some have a hairy covering.

With regard to what we know at present of means of prevention, our best course is, if we can, to nip the evil in the bud by destroying the very first Aphides that appear. This plan is constantly carried out in field management with regard to the Bean Aphis. When the Colliers, as they are called from their black colour, appear on the tops of the Bean shoots (see Fig. 132), these infested shoots are cut off. If the shoots and Colliers on them are destroyed, the attack, or at least a great deal of it, will be stopped; but if, instead of carrying off the fragments and destroying them, they are only thrown on the ground, the Black Aphides will just walk, or fly, back again to the growing Beans, and the labour will have been in great part lost.

This same plan is useful throughout the summer for all plants or trees, such as Apple, Plum, Cherry, or others, in which Aphides, or Green Fly, as they are often called, collect in great numbers on shoots, which may be cut off without hurting the plant. Thus, if the shoots and Aphides on them are properly destroyed at once, we get rid of centres from which attack is constantly spreading to do present harm. Also we may thus lessen the amount of next year's attack. It is the autumn brood of males and females which provide the eggs to start the attack of the following year; and therefore anything which lessens the production of broods is useful. The shoots, however, should always be destroyed at once; not merely thrown aside to wither gradually, whilst their infesting hordes gain wings to go home again.

A healthy, yet not rank, growth is one great means of lessening the bad effects of Aphis attack; as in the case of other insect attacks, the plant is thus supported through its troubles. But there is a further reason. It has been found that Aphides come to maturity more rapidly where the plant growth is so 
stunted, or the Aphides themselves are so numerous, that it may be presumed the nature of the sap is different to that in the full flow of the healthy shoot, or the Aphis is rather shortener of its food. Necessarily, maturity coming sooner, the successive broods. are more rapidty produced, and the numbers greater.
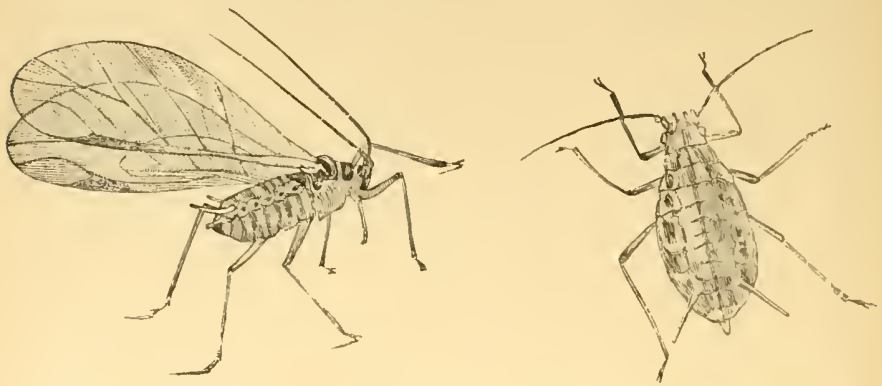

FIG. 139.-Aphis humuli: winged and wingless viviparous females, magnified.

Where we can tell with certainty that some species of Aphis migrates at a special season, from one lind of plant or tree to another, we have a most serviceable method of prevention in our hands.

It does not seem now to be open to doubt that a great part of the yearly attack of Hop Aphis, or "Fly," comes on the wing from Sloe, Damson, or plants of the Plum tribe. 'This was long ago stated by German entomologists, also laid down ly at least some of our Hop-growers; and in 1884, after careful examination of specimens of Aphides both from Hop and Plum, and reports from Hop-growers (noted at length witl figures in my lieport for that year), I mentioned that there appeared to me to be reason to believe that the great attack, which usually occurs in the form of "Fly" about the end of Nay, comes on the wing from Damson und Sloe, as well as (which at this present date of writing I still think is to some extent the ease) from IIop. 
In 1887, Prof. Riley (Entomologist of the Department of Agriculture of the United States) set the matter of migration from Plum, to Hop, beyond doubt by his observations, of which a part was read before our own British Association; he mentioned:"Phorodon humuli hybernates in the winter egg state, this egg being fastened to the twigs (generally the previous year's growth) of different varieties and species of Prunns, both wild and cultivated." From the winter egg Prof. Piley found the female, the mother of the coming tribe to be hatched, the winged descendants of which female take flight to the Plum.

The existence of many generations on the Hop, during summer, we are all well acquainted with; but during Prof. Riley's stay in Europe, and more espesially in England, he personally observed the point not previously worked ont, of the antumn migration of the Hop Aphis, back from Hop to Plum, in the close of antumn.

These observations, coming from such a high anthority as Prof. Riley, give thorough confirmation to the belief previously held as to migration; but still I do not think that in this country the whole of the attack comes on the wing from Plum, Ditmson, or Sloe, becanse (amongst other reasons) we have found Aphides - that is, wingless females and lice-on Hop as early as the end of March and the beginning of April, long before the attack coming on the wing made its appearance.

The Hop Aphides (the Phororlon or Aphis humuli) may be distinguished from the Plum Aphis, and from others of the Aphitince, by the horns being hardly longer than the body, together with the lowest joint being toothed or gibbous, and the tubercles on the forehead each having a strong tooth. The legs are short, and the lioney-tubes long.

Where there chance to he large duantities of Sloes, as, for instance, Sloe hedges, in the neighbourhood of Hop-gardens, these at least might be got rid of without loss. 
The number of remedies-such as solutions or mixtures of tobacco, paraffin, quassia, or other applieations in the form of washings or syringings-are endless, and recipes are not given here, as these

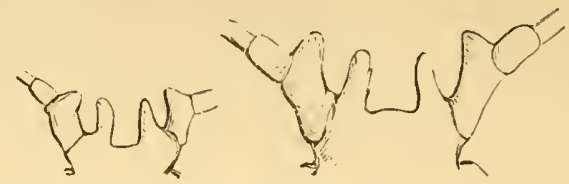

FIG. 140.-Hop Aphis : base of antenna and frontal tubercle of1, young form; 2, wingless female, magnified.

applications lie in the special province of the Hopgrower. It may, however, be noted that sometimes. washes fail in effect from the operator not being aware that in the case of many Aphides the skin is covered with a lind of mealy coating, which throws off watery application. Consequently it often happens that unless the washing lodges amongst the Aphides so as to kill them, or, again, the syringing is given with snch force as to knock them from the plants, the insects are but little hurt. It is for this reason that soft-soap is so largely used, especially by Hop-growers, for the washes: it is sticky, and thus adheres in some degree to the Aphides; also it may be made the relicle of any other application, with which it may be desired to poison the Aphides; and, thirdly, it is a good fertiliser, which, as we have observed, is important in Aphis attack.

'T'he great thing, however, that we need to know, in order to check Aphis attack, is where and how each kind spends the winter. Meanwhile our best hope as to prevention lies in allowing as few shelters as possible on trees, or in neglected bark (in fruit or tree atta(k), or at the roots of wild grasses round fields, for possible shelter of grain Aplis, and (generally) being alive to the necessity of not letting everytling drift withont thonght of the reasons low, or why, things 
happen; and, for remedy, in use of washes which are known to be suitable for the purpose in hand.

The Aphides of the remaining four tribes are much fewer in number; and of these the most important to us, in a farming point of view, is the American Blight Aphis, Schizoneura lanigera.

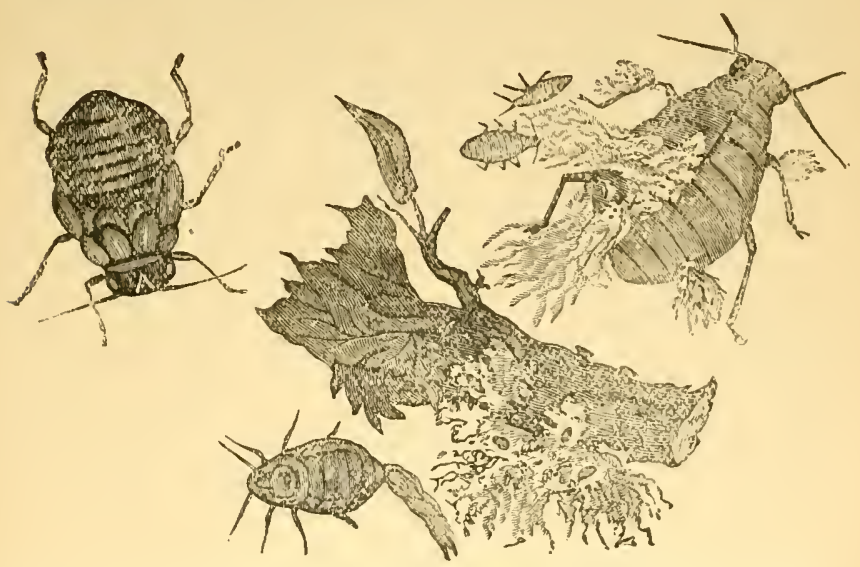

Fig. 141.-Woolly Aphis: infested Apple-spray, nat. size; wingless viviparous female and young clothed with woolly fibres; small egg-bearing female beneath the spray; pupa;--all magnified.

The few kinds of Schizoneura that we have may be known by the singly-forked third wing-nerve, and also by the cornicles (or honey-tubes, as they are sometimes called) being wholly, or almost entirely, absent. They live in rery different places: one, for instance, is found on Black Currant roots in flocky matter, like that of the most destructive kind, which is the American Blight.

This Woolly Aphis, or American Blight, is chiefly to be found in neglected orchards. The Aphides shelter themselves for the most part in crevices of the bark, or where a bough has been injured, or under young bark healing over wounds; but they may be 
found on the young shoots, and the leaves, and are distinguishable by the white cottony material which surrounds them. I have also found this kind of attack on the rootlets. The piercing of the Aphissucker causes the growth just below the bark to become swollen and pulpy; then the cells divide, and the bark above splits, and thus openings are formed, which give the Aphides new liding holes; and the diseased growth from their punctures is continued, until large tumour-like masses are formed, and the trees are very seriously injured.

The best method of checking attack is to keep the bark of the Apple trees in such a healthy state,-by means of proper pruning, and clearing away injured branches, and useless and cracked bark (and other measures), - that there may be as few crackis, and crannies, and half-healed spots, as possible ; consequently as little as possible of the shelter in which this Aphis delights. Also, when the white wool in any nook, or on any soft shoot in summer time, shows the presence of the pest, the shoots should be at once cut off, and some remedy should be well brushed or rubbed into infested nooks.

The number of different kinds of applications adrised are almost beyond counting, though the principle throughout is one. But anything will be of use which will stifle or poison the Aphides, without hurting the bark of the tree; and probahly common soft-soap, or soft-soap with a little sulphur dissolved in it, or paraftin or tobacco-juice added to it, and well rubbed or washed in, so that it may be sure to reach the pests in their sheltering noolis, will answer as well, or better, than most of the many suggested applications.

Some of the applications said to succeed should be applied (if at all) with groat caution, or they may do more harm than good by soaking into the bark. Tar is especially to be suspected, for it is apt to melt in the lieat of the sun; and turpentine, resin, and fish- 
oil, mixed and put on warm, and, in fact, anything that will thus choke the bark, is an unsafe application.

For attack below ground, the best treatment seems to be, clearing away infested roots and soil round them, and drenching the spot well with soft-soap washings or drainings from stables.

We have only six kinds of Schizoneura, and these may be known by the one-forked wing-nerve, and by having either no honey-tubes (cornicles), or exceedingly small ones. (See Fig. 141, p. 183).

The tribe of Pemphigine is generally known from the others by having no forks to the third wing-nerve; also by having the cornicles absent, or rudimentary.*

This division hardly concerns us agriculturally. There are only about seven British kinds, and, like the above, they live in very various places; some are Gall-makers, and one does a great deal of harm at Lettuce roots. When this is at work, it is desirable to water well with anything that will keep the soil thoroughly moist, and be favourable at the same time to growth; bearing in mind that below ground, as well as above, the great point in killing Aphides is to apply something that will choke up their breathingpores, as mere water, or merely fluid applications, flow off them, unless special measures for flooding are adopted.t Also, when ground is known to be infested, it is very desirable to put on a killing dressing : a handful of fresh gas-lime, put into each

* The Pemphigince have usually no fork to the third wing-nerve; but in the case of the very small Thelexes dryophila, sometimes found on Oak, this third oblique wing-nerve has one fork. The history of Aphis life is so involved that it is very dillicult to convey any plain and elear general view; but in the above short sketch I have endeavoured to give a correct abstract of the present state of information on the subject, following the elassifieation given in Mr. G. B. Buekton's admirable work, 'Monograph of British Aphides.'

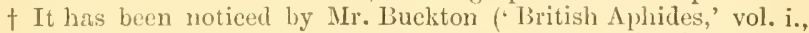
p. 35) that "complete submergence in water speedily kills most Aphides,"-an important observation, well worth consideration in the ease of root-feeding Aphides. 
hole from which a plant has been drawn, will do a deal of good; and any of the dressings we have noticed to clear out insect-life, applied from time to time, would be of service.

The simple point is not enough considered with regard to Aphis attack in the ground,- that unless by any chance infection was carried on plant, or in earth, the insect must have gone down at some previous time to start the attack; and if we kept the earth in such a state that it could not go down, we should not
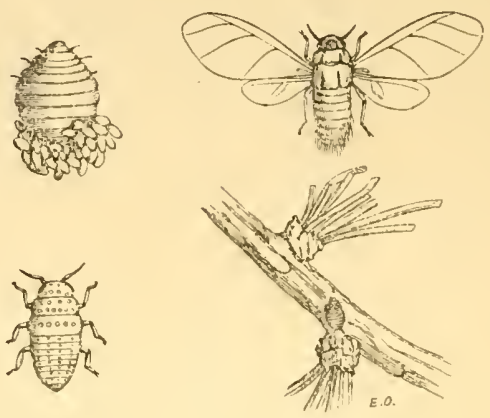

Fig. 142.-Larch Cherme : female, with eggs; winged specimen, and larva; all much magnified. Infested Larch twig.

have so much trouble. I would, therefore, strongly advise such application to the surface, and such care, that there should be no eracks, or the earth dried away from the plant, or other means allowed for ingress of the Aphis, as might reasonably be expected to keep it out.

The remaining tribe that is winged, includes the Chermes, and (possibly) the Phylloxera. It is known as the Chermesine, and has no third wing-nerve (has three, not four, oblique wing-nerves), and no cornicles.

The Chermes abictis is one of the best known of this 
family, from the singular Galls, like small Pine Apples, which it causes on Spruce Fir shoots.

The Larch Chermes, or "bug" (see Fig. 142), is sometimes very common and very injurious on Larch shoots. This is an example of a kind in which the female lives through the winter, and also never gives birth to living young; she is exclusively an egg-layer.

The Phylloxera is a world-wide trouble, but does not affect $u s$ agriculturally; therefore I am thankful not
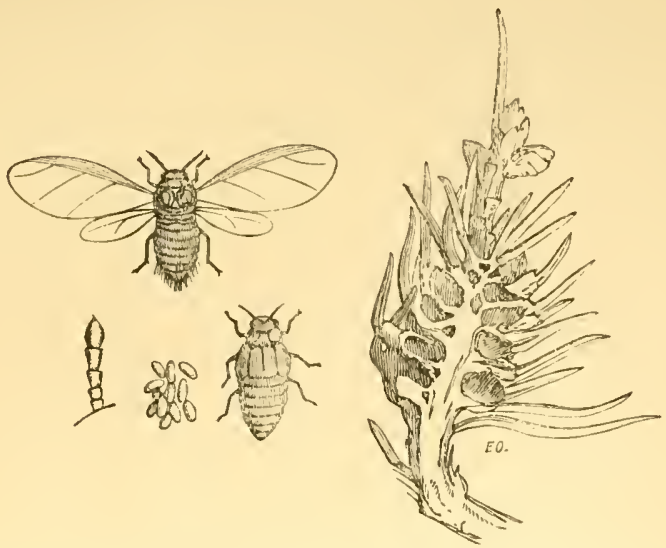

Fig. 143.-Spruce Chermes : female, pupa, eggs, and horn; all much magnified. Section of Gall.

to be obliged to enter on what at present seems an unconquered difficulty.

The fifth tribe of Aphides (the Rhyzobiince) feed mostly on grass-roots, and are wingless; and should they be found troublesome, the use of the cultivator, plenty of gaslime, and similar measures, would probably clear them out.

It is exceedingly difficult to give any clear view of Aphis life, or means of prerention, for few are known, excepting in cases where the plants are under cover, 
and therefore fumigation can be brought to bear. But the principle throughout appears to be this:Check attack by diminishing lurking-places, and also by pruning off and destroying infested shoots and parts of plants, or infested leaves (as with Cabbage), as much as you can; and where you can bring washes to bear, use soft-soap as a foundation; but where the application may be run into the ground, and thus remain round the insects, ammoniacal water, or drainings from stables, lime-water, or other drenchings poisonous to insect-life, and that will not hurt the plant, have proved useful.
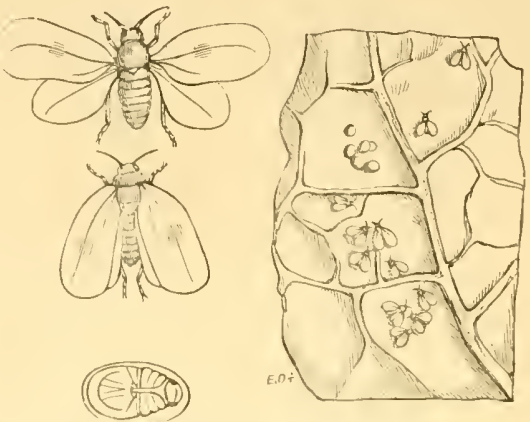

FiG. 141.-Aleyrodes proletclla: Fly and pupa, much magnified; Flies on leaf, twice nat. size.

The third family of the section Dimera of the Homoptera contains the Aleyrodide. These are not the cause of any very great amount of mischief, but they require mention on account of their peculiar difference, in larval and pupal condition, from that of the imago. Thus in the characteristics which are most observable, without minute inspection, they differ from most of the other divisions of this order, excepting the Scale insects, or Coccide, to which they bear many resemblances.

'Ihis A. proletella is a small form-minged I'ly, very 
like a small powdery White Moth in its appearance. It may be found on different kinds of Cabbage, more or less, all the year round, and towards autumn in such enormous quantities that, if the plants are stirred, the soft white flies will rise and float in the air, and settle down like miniature snow-flakes, whence its name of the Snowy Fly. They rest for the most part beneath the leaves, and draw away the sap with their suckers; and at times do a good deal of harm.

As far as is known, these Snowy Flies breed in winter as well as in summer.

The female lays her eggis in a patch on a leaf; these hatch in about twelve days, and the young spread themselves on the leaf, and shortly become covered with a scale, white, with two yellow spots. In this state they much resemble the common Scale insect, and they stick fast to the leaf, which they pierce with their sucker. In about ten days they turn (beneath this scale) to a pale chrysalis, with red eyes, and in about four days more the perfect insect comes out through the scale.

The "Scale Insects," or Coccidce, are the third section (distinguished as Monomera, from their feet having only one joint) of the Homoptera. These insects do great harm by drawing away the sap by means of their suckers.

There are many linds, differing in various points of structure, as well as form; but in the case of the Apple Mussel Scale (Aspidiotus conchiformis, Curtis), which is sometimes very hurtful in orchards, this shell-like husk, which is in shape like a minute mussel-shell, adheres firmly to the bark during winter; and under it, but not attached to it, there lies the dead body of the female Scale, and fifty or more eggs. In spring these hatch, and from them come small white flat insects, furnished with eyes, horns, six legs, and a sucker. T'hese are very active at first ; but presently each Scale larva runs its sucker into some spot it can 
pierce, begins to feed, and ceases to move. A secretion of waxy material takes place on its back, beneath which the scale forms; and after various moults, and additions by secretion to the size of the Scale, the change of the insect under it takes place to the perfect state.

This, in the female, is to a shape like that of a globular flattened maggot, greenish in colour, without jointed limbs, which lays eggs, and dies.

The males (I believe, in the present case, first
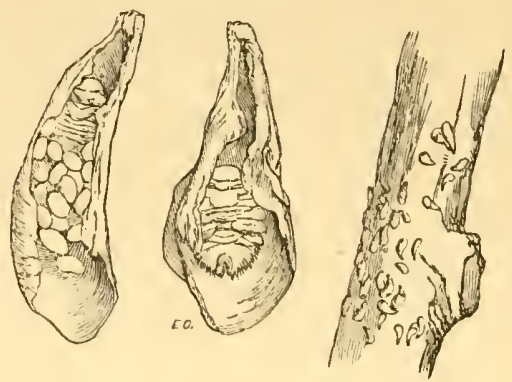

Fra. 145.-Apple Mussel Scale-female and eggs ; magnified. Twig, with Scale; nat. size.

observed not long ago by Prof. Riley) have one pair of whitish wings, and no proboscis.

The best methods of getting rid of these Scales are to prune off infested boughs, where this can be done. Where it cannot, rubbing off the Scales by means of cloths or brushes, after moistening the bark with water, or scraping them away with a knife, gets rid of many; and, generally, the same lind of remedies are useful as are applied for American Blight, such as soft-soap, with some mixture of paraffin, kerosine, or other addition, which may stifle the Scale insects which have been disturbed, and make the bark unsuitable for attack. 


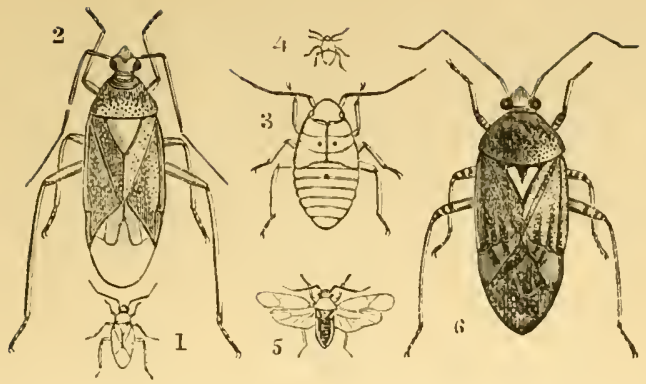

FIG. 146.-1 to 4, Potato Bug; 5 and 6 , Hop Bug, nat. size and magnified.

The order of Plant Bugs * includes both plant and water insects, which may be known by a kind of leathery patch at the base of the front wings, "dissimilar" from the rest of the substance, whence the order takes its name of Heteroptera, or "dissimilar-

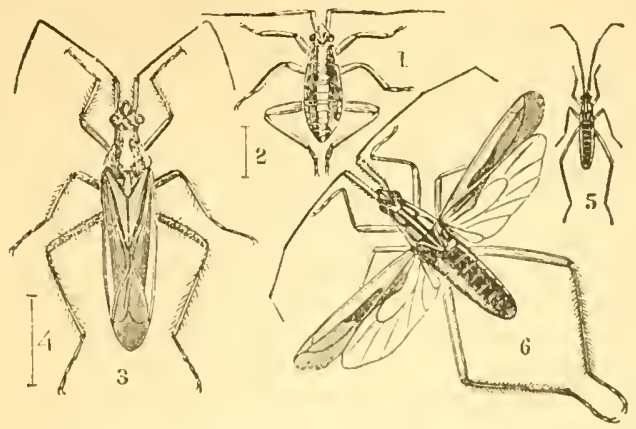

FIg. 147.-1 to 4, Grass Bug; 5 and 6, Wheat Bug, nat. size and magnified.

* The insects included in this and in the precednng orler by Prof. Westwood, are included, at the present day, in the order IIemiptera (or Rhynchota, of Burmeister), and elassel respeetively under the suborders of Hemiptera-Heteroptera, and Hemiptera-Homoptera. I have retained the distinction as given. 
winged." The long-legged insects known as watermeasurers, which we see skimming about on the surface of ponds, and the Water Boatmen, which by the help of their long oar-like front legs sweep through the water like insect sliffs, are common examples of the water frequenters of this division.

The Plant Bugs sometimes do har'm by sucking the

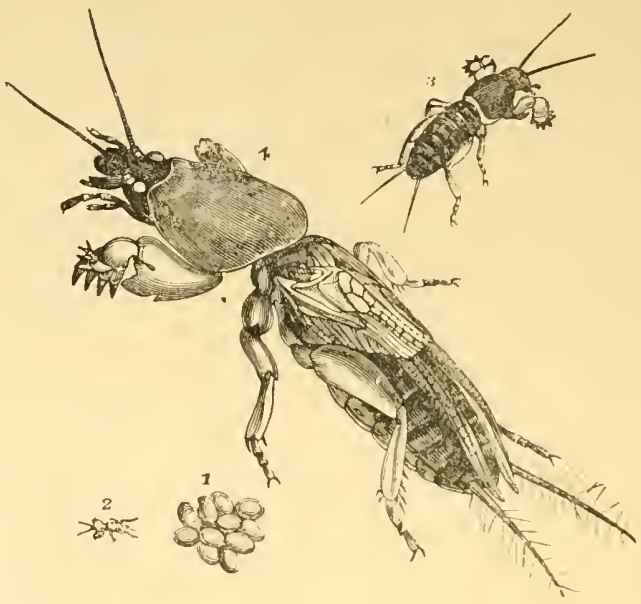

FrG. 148.-Mole Cricliet.* Eggs, larra of two ages.

juices of plants, especially the Lygus (Phytocoris) solani, which attacks Potatoes; but they are, so far as I am aware, rarely injurious in this country to any serious extent.

Some kinds, of a longer narrower shape, are to be found on Wheat and Barley. The Wheat Bug (Miris tritici) has also often been found on Grass in marshes; the Barley Bug (MI. dolabratus) is exceedingly common in Barley, and on flowers of Grass near (see Fig. 147).

* The Mole Cricket is one of the Orthoptera, and sometimes does much haim by feeding on roots both of Grass and other plants. 
Some of these various out-of-door Bugs probably do good, by means of their carnivorous habits; and with regard to the wingless kind, which, to our misfortune, occasionally teaches us that feeding on animal juices, by means of a sucker, is a characteristic of this order, I think we need not enter on its prevention here.

Three orders still remain of those of which the insects vary little in appearance throughout their lives. Of these three we do not need to enter on that of the Earwigs, Euplexoptera (Fig. 149), for thougl

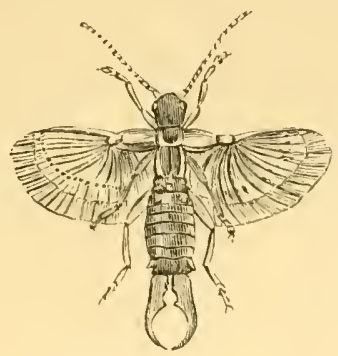

FIG. 149.-Earwig.

injurious in gardens, it does not often occur as a really widespread and serious infestation in fields. Nor ito we need to enter on the Orthoptera, the order that includes Grasshoppers and Crickets, so far as injury to our Islands is concerned; but it is worth notice that we are now and then visited by the true Locust. The unsuitableness of climate makes it very unlikely we should ever be serionsly troubled by this terrible scourge, but nerertheless some of the observations taken by the Entomological Commission of the United States of America, as to the effect of cold, and deep burying of the eggs, in retarding date of hatching, are of much practical interest to us, for the size of the eggs allows the specimens to be observed with certainty, and from what happens to them we mily at least get hints as to what very likely hapnens 
with the eggs of other insects. It is found essential to great amount of Locust presence that the eggs should be healthy, and properly deposited; that is, at the proper depth below the surfuce, and otherwise in favourable circumstances. The natural depth is an inch or thereabouts below the surface; it was found that from eggs placed two inches deep, about a third of the young Locusts managed to make their way to the surface, but none came up from eggs buried mre than two inches deep. Eggs hatched that were buried

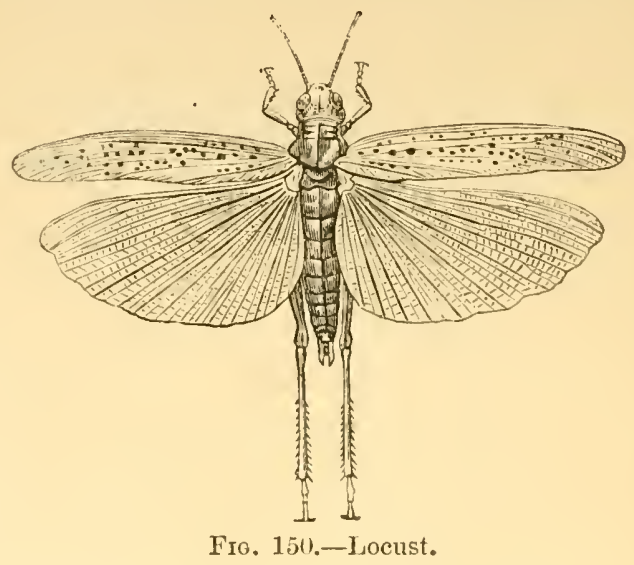

as much as twelve inches deep, and the young Locusts worked their way for an inch or two through the earth, but (as we just observed) did not come up to the surface; and at the time when these were hatched, eggs buried deeper than twelve inches were still unhatched.

It is further noticed that eggs placed deeper, though they remained unhatched whilst buried, were not harmed by lying underground, for on being brought to the surface they hatched at once. Further, it was found, with regard to the effect of warmth or of cold in hastening or retarding hatching, that the Locust 
'egg will bear freezing, but that at a uniform temperature of $85^{\circ}$, the time required for hatching was 31 days; at a temperature of $50^{\circ}$, the time needed was 116 days. Other dates are given, showing that so long as the warmth was considerable,- that is, not lower than $60^{\circ}$,- - though the time of hatching was lengthened increasingly with the drop in temperature, yet it was not very greatly altered; but below $60^{\circ}$ the time was much lengthened.

How far these experiments may apply to eggs of - our farm-pests we cannot be quite sure till we have proved it, in each case; but if, as is likely, the eggs will hatch at a moderate depth below the surface, and the grubs perish because they cannot come up, we have a useful piece of information; and further, in the fact of eggs lying unhatched and also uninjured when buried deeply, we may have a reason for the occasional entirely unexpected appearance of some crop-pest in a single field, but nowhere else in the neighbourhood.

But howerer this may be, we have instances liere of the use of putting eggs in unnatural places and circumstances, and for this purpose no means are better than thorough cultivation of the land. Thus whilst-just as with weeds - a number of the eggs are turned safely down to a depth from which we may hope they will not come up again, other's will escape, but there will be a certain quantity destroyed by what is termed desiccation, or drying. If an egg which is naturally placed below the surface of the earth, is thrown out on the surface, to the effects of air and sunshine, the fluid within will dry up, and the embryo within will consequently be destroyed.

The remaining order is that of the Thrips, Thysanoptera. 'T'hese are very small insects, which sometimes do much harm to corn. They are nearly alike in shape in all their stages, but as they are scarcely large enough to be seen by the naked eye, the figure gives a better idea than description (see Fig. 151). 
The perfect insect of the Corn Thrips (Fig. 151, 1 to 4) is blackish, but in the first state of larva or grub it is of a deep yellow; in the second it is of a paler yellow, with whitish wing-cases.

These Thrips are to be found from June onwards in the growing Wheat ears, and sometimes in the sheathing leaves of the stem. They feed on the corn grain, by piercing into it with their sucker-like jaw

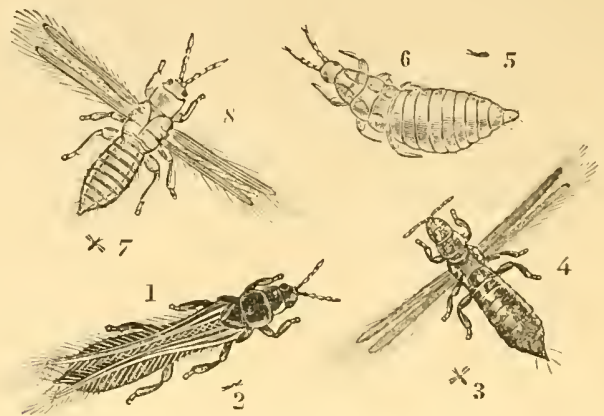

FIg. 151.-1 to 4, Corn Thrips; 5 to 8 , Potato Thrips and larra : nat. size and magnified.

apparatus, * and thus draw away the juices and cause the grain to shrivel.

Another kind, also figured above, infests the Potato, drawing away the juices in the same way as the Corn Thrips; as do also the Aphides, Scale insects, Plant Bugs, and some others, which we have just noticed, with their variously formed sucking apparatus. In the case of the Potato Thrips, dusting with dressings of lime and soot, or other mixtures, might do good; but for the Corn 'Thrips it seems impossible to find any

* The precise charncter of the mouth of this insect has been much discussed. The result appears to be, that though it is shown to feed by suction, yet that it hias a pair of long bristle-like mandibles (see Introd. to 'Classification of lnsects,' by J. O. Westwool, vol. ii., 1. 2). I have therefore in the list of orders, page 23 , placed "Thrips," Thysanoptera, amongst the Insects with jaws. 
application, as any of those used to destroy the Thrips would hurt the corn. The chief means of prevention seems to lie in clearing stubble, or in deep ploughing to get rid of Thrips which may be wintering at the roots of the removed crop, or in destroying wild grasses on which the eggs may be laid round the fields.

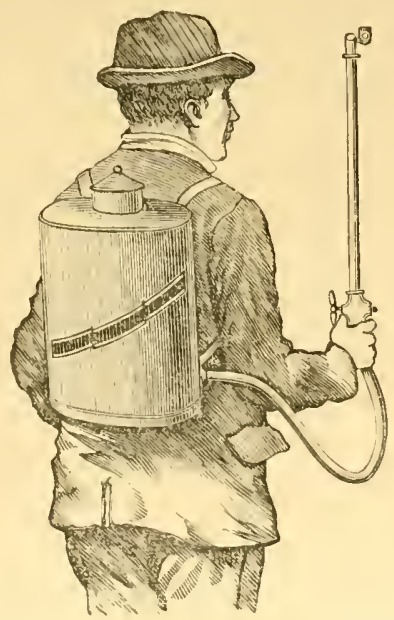

FIa. 152.-No. I Eclair, or Knapsack Pu.np.

The Knapsack Sprayer, figured above, is a very convenient form, and is noted here as being serviceable for distribution of washes and sprays for destruction of Aplides, Scale insects, \&c.; as well as for the distribution of Paris-green, mentioned at 1. 140. The Sprayer is procurable from Messrs. C. Clark \& Co., Windsor Chambers, Great Saint Helens, London, E.C. 


\section{CHAPTER X.}

Notes on Slugs, Flukes, Eelforis, Mlllepedes, and Red Spider.

With Observations on Methods of Studying Habits of

Farm Insects and other Crop Pests.

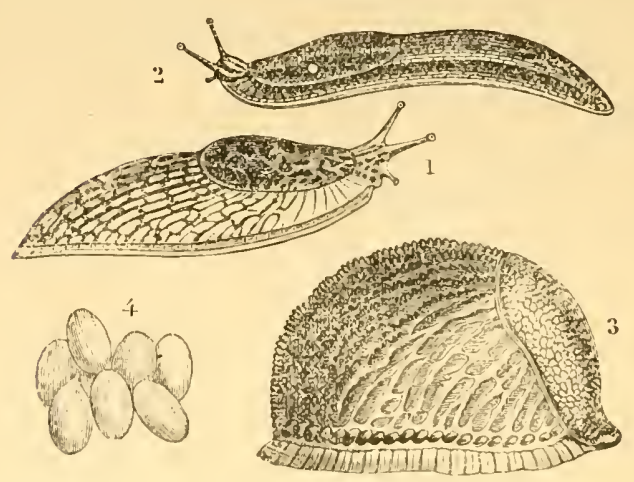

Frc. 153.-1, L. agrestis, Field or Millyy Slug; 2, L. ater, Black Slug (less than life size); $3, L$. ater (var. empiricorum) in repose; 4 , eggs.

Is the preceding pages I have endeavoured to place before the realer some of the most important points in classification and methods of life of insects, and also of the principles on which these methods of life shonld be followed up in order to check their ravages. T'o follow this up in the detail which this subject (so important in its bearing on the food supplies of the nation) deserves, would require more space, and also much more time and derotion to the subject, than can 
be given by any save special students of farm crop pests.

One thread of serviceable knowledge will, however, be seen to run through the whole of the subject under consideration, namely, - that by observing the habits of the crop insects, and using remedies which lie in the common course of agricultural operations, under the guidance of a few common-sense principles, we may in very many cases save our crops.

With regard to the direct study of Insect life, by observing the history of many insects in their different stages, the student will understand clearly what an insect is; also that it goes through three changes of condition; and also that insects are classed in large divisions called Orders, according to the nature of these changes which they pass through up to the perfect state; and according to the nature of their wings when perfect; also that the Orders are named from the nature of the wings.

It is very important to know, and to be able to show, that the manner of insect life is fixed according to regular laws, because there is still a kind of floating idea in many people's minds that insects come in some vague way; that they are formed from for or mist, or water, or decay; and that, like the ghosts and hobgoblins of childhood, they are mysterious enemies which no one quite knows how to deal with. But. once get the real history fixed as a fact, and then we know how to act.

It often matters very little whether we know the scientific name of an insect; but it matters a creat deal, when attack is going on, that we should know the nature of the insects that cause it, and also their habits in connection with the injured crop. 'There are sereral kinds of Wireworms; sereral kinds of Daddy Longlegs; several kinds of Turnip-Flea Beetle. Each of these sets (so to call it) lives much in the same way as its brethren, and it is needless (for all farming purposes) to be perfectly informed about the scientific 
differences between one or other of each set; but it is of great importance to be able to tell whether it is a Wireworm, or Daddy Longlegs grub (or so on), of some sort or other, that is injuring a crop, in order that the right means may be used to save it from the insect; and I trust that in the preceding Chapters sufficient information will be found to enable the observer to tell what orders such crop insects as are commonly met with belong to,- that is, whether they are Flies, Beetles or so on; but either for teacher or student it is serviceable occasionally just to take each Chapter separately, and look at the figures. Thus the student will see, and be able to fix firmly in the minds of those who apply for information, what are the main points of an insect in each stage.

Say it is the order of Butterflies and Moths that may be under examination; the student cannot fail to notice that the caterpillar's have commonly three pairs of claw-feet, and one to four pairs of sucker-feet, under the body, besides the candal pair; also that there are two slightly different forms of chrysalis, belonging respectively to Butterflies and Moths; and also that the shape of the horns of the Butterfly differs from the many shapes of those of the Moths. If the teacher had tried to explain this without a picture, the pupil would probably have been without an idea of what was described; but one glance at the successive pictures will have told him at once what are the main points of a Butterfly or Moth, and its caterpillar and chrysalis.

The object of minute scientific descriptions is, that we may liave a correct knowledge of the appearance of what is described; but there are few who can tell nearly as well from a description as from a figure what the described thing is like, and often a wrong idea is thus established. I would, therefore, suggest that in first instructions to pupils, teaching should be giren as much as possible by the real specimens, if these are available; otherwise by means of good 
figures. Also, when it is needed in field work to make out what insect it is which is injuring a crop, I would strongly advise the enquirer not to harass himself by doing what is called "looking out the insect," but take the state of the crop as the starting-point. Have a book with descriptions of the common erop attacks, and a good number of figures, both of the injury, and of the insect that causes it. Then look out the crop in the index, turn to it in the book, and turn over the pages relating to attacks to that crop until you come to a picture or description that suits the attack; and so you will soon know clearly (if it is one of the commonly injurious kinds) all that is needed to be known or is known about it, instead of, after long delay and trouble, still being quite uncertain whether you are right or wrong. There are not very many attacks that are commonly injurious to a serious extent to food crops, fruit, and timber, in this country ; probably if we say two hundred that would be quite an outside reckoning; and many of these may be known just as well, or better, by the state of the attacked vegetable as by the appearance of the insect.

There is one more point of farm insect study which it is also desirable to draw attention to. Our object here is to sace the crops, and to learn and teach whatever we can on this subject in the very plainest way. Plants, insects, manures, farm implements, - all have to be thought of and spoken of ; and in every case it is highly desirable to use the words that will be most certain to be anderstood by those ne are speaking to. In regard to the insects I would strongly alvise spealing of them by their commonly used English names; but still, with regard to the scientific names, it is very desirable to observe, and show our pupils, that these have a very precise meaning. Just as, in the case of the orders, there is a distinct serviceable meaning for each name; so is there in many cases for the names of the lesser divisions; and it is desirable for those who teach to make themselves acquainted with the 
meaning of these words, as thus, more likely than not, they will be put in possession of some special point, some leading peculiarity of the insect or of the division, be it genus, or family, or order, to which it belongs.

These names may or may not help us practically; but it often happens that the second name-the. specific name, as it is called, because it is used only to one species-describes some point of marling or colour, or of the kind of plant which the insect mainly frequents, which is very convenient to know. In the case of Aphides, for instance, they are often named after the plant which they infest; and with this tribe, especially, running down the columns of an index for the plant name often sares much time and trouble, where we are at a loss amongst the scientific insect names.

With regard to gaining information of serviceable methods of remedy of attack when it is present, it is of great use to benefit by the collected opinions of many farmers (of practical and scientific men), and their experience as to different methods of treatment that answer on different soils, camnot fail to be of most excellent service; but still it should be borne in mind that each man, by a little observation of the method of attack, which is often only too plain, and a little quiet thought as to what measures can be brought to bear, might often help himself very effectually.

With a slight linowledge of the habits of insect life, adder to his own of the agricultural measures that could be used to destroy the pest, or at least lessen the effect of its ravages, each grower would be fairly able to cope with attacks as they occurred; whereas if he depends only on advice, besides the damage from delay, he is very likely to get suggestions not suited to the particular circumstances. The farmer may not know the history of the insect; but, on the other hand, the entomologist very seldom linows all the practical workings of growing a crop, which it is 
necessary to know before advising measures which can be depended on to answer at a paying rate.

In many cases the different items of treatment which go to make up good farming will of themselves keep down a great deal of insect attack. By good cultivation of the surface, and proper as well as liberal manuring, by rotation of crops, and clearing fields and borders of useless trash and weeds, we turn out a great quantity of the pests which are harbouring in the ground, and also ensure a good healthy growth, such as will support the crop under moderate attack; and by the rotation of crop and absence of weeds we are often able to present starvation to our grubs, as many of them will only (or perhaps we should say, can only) live on special food.

These are the broad principles which will be sure to be of use. We shall not be free from insects any more than we shall be free from weeds; and we need a. great deal more solid field information about the habits of crop insects (and experiences of paying means of prevention) before we can think we hare them thoroughly in hand. Nevertheless the last few years have added enormously to our information, and have shown us how at least we may greatly diminish the amount of injury our crops suffer.

Details of recorded amount of this loss per acre to special crops would take too much space to insert here; but the fact of the Hop failure, through Aphis blight in 1882, causing a loss of over a million and a half pounds sterling, and the loss on the Turnip crop, by Turnip-Flea Beetle in 1881, amounting to fully, or to more than, half a million, may be taken as some slight guide to what is going on.

From insect injury, and from injury by what are described as "insect allies," the losses we suffer yearly are a most severe drag on the resources of the growers, as well as a national loss; and on these latter infestations, which are often as serere in their effects as those of insects on the attacked crops, and 
also are sometimes confused with them, some obserrations may be desirable.

In the following pages some notes are given on Slugs; and also on Water Snails, as a means of dessemination of Liver Fluke in sheep; also on Eelworm attack to various crops; also on Red Spider and Hay Mites; and on Millepedes, often known as Julus-worms, or False Wireworms.

Slugrs are injurious to almost every kind of crop. They belong to the Division Mollusca, thus described, "Animal in pairs, the body and its appendages soft, inarticulate (not jointed), enveloped in a muscular skin, commonly called the mantle, which is extremely variable in form, and has developed either within or upon it a calcareous portion, consisting of one or several pieces commonly called a shell." - Trans. from De Blainville's 'Manuel de Malacologie et de Conchyliologie,' given in Sowerby's 'Conchological Manual,' p. 3. The Shell Snail, "Pond Snails" or Limnca, and Pond Mussels, are familiar examples of Molluses with shells; the true Slugs or Limacide liave a small morsel of a lind of shell-like formation sometimes shield-shaped, placed on the fore part of the back under the slin called the mantle.

The true Slugs may be generally described (when extended or in movement) as being long, more or less spindle-shaped, cylindrical or tumid, head prominent, "tentacles" (commonly linown as horns) four in number, and two eyes placed on the tips of the uppermost pair of horns (see 1 and 2, Fig. 153).

When at rest or alarmed they draw themselves together into a lump, as shown at 3, also Fig. $15:$.

The Ficld or Milliy Slug, L. ayrestis, figured at $\mathbf{1}$, p. 198 , is a somewhiat spindle-shaped lind, about an inch and a third long, greyish in colour, and with milliy slime, and is very common.

The Arions, or Black Slugs, of which one is figured in repose at 3 , and less than nat. size at 2 , 1 . 198, are partly distinguishable by the skin being wrinkled, and 
the shield on the back shagreened. Arion ater is as much as four inches long. The colour of these two kinds of Arions is very variable, and they are stated to lay their eggs separately under ground.

One very important point to be considered, in methods of prevention, is the circumstance that the Slug can exude slime, so that it can " moult-off," as it were, a coating of lime or other obnoxious dressing thrown on it, and thus (quite getting rid of it together with the slime) be no worse for one application of any ordinary dressing. This moulting the Slug can do a few times successively, but after the operation has been repeated two or three (or at least a very few times) the creature requires an interval to regain the power; the slime reservoirs, or power of exuding slime, are exhausted for the time being, and the obnoxious dressing consequently takes efiect on the skin of the Slug and kills it.

Where there is bad Slug-attack in fields, attention is particularly needed to these points. On un-oceupied land, such a heavy dressing of gas-lime, or quick-lime, or salt, may be put on, that wherever the Sling crawls there is the obnoxious stuff, and it soon loses its slime-producing power and perishes. But very often, where erops are infested, lime is only thrown in the middle of the day or at any convenient time, just when the Slugs are sheltered from the dressings falling on them, and as it soon slacks it does very little towards getting rid of the infestation. I lave seen the Slug resting as comfortably in the slacked lime as it would under a stone.

Or again, if one dressing is given in the morning, or when the Slugs are out at feed, it often happens that it is not followed up by another before the Slugs cau protect themselves.

To do good the dressing should be thrown in the evening, when the Slugs are at feed, and again the following morning. If the Slugs should again reappear next evening, the dressing should be given 
again; but if it has been properly applied, probably there will be no need.

One or more kinds of the Marsh or Water Snails (Limnceus, scientifically) play a most seriously injurious part as "hosts" of the Liver Fluke of sheep, the Fasciola hepatica (sometimes known as Distomx hepatica), during the early stages of its life. The Limncens truncatulus, of which the shell is figured below somewhat larger than natural size, is the kind

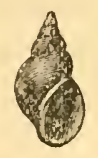

1

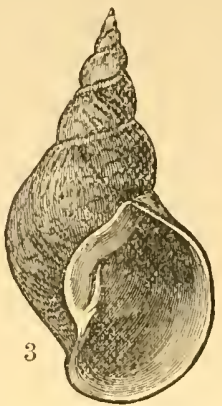

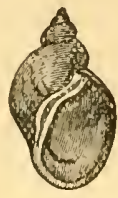

2

Fig. 151.-Shells of Water Snals : 1, Limnens truncatu'ns ; 2, L. pereger; 3, L. stagnalis.* Not quite twice nat. size when fullgrown.

which is especially recorded as infested by the Fluke in its early stages.

Regarding presence of infestation in the L. pereger, there has been difference of opinion. These "Marsh Snails" wander about, and both kinds are nearly amphibious; they may be found in damp grass as well as in pools. Of the $I_{\text {s. }}$ truncutulus it is said that it is to be found on "Banlis of slow and muddy rivers, and streams, marshes, ditches, grassy pools, waterfills, and moist places everywhere from the northernmost point of Zetlind to Jersey." + And of the $L$.

* The $I$. stagnalis is merely adiled, as, though I am not aware it is a "host" for lluke, its comparatively large size conveys the aplearance of this genus of shells more plainly.

t'Brit. Conchology,' by J. (iwyn Jeffieys, vol. i., p. 116. 
pereger " that it is fond of wandering, and may be met with at some distance from its native element, or climbing up the trunk of a Willow tree."-J. G. J.

During the years in which I had personal knowledge of habits of Limneeus at Sedbury Park, in West Gloncestershire, the L.pereger was excessively prevalent in small field ponds or drinking places, where floating water plants, weeds round the bank, and more or less mud, according to weather or season, gave every encouragement to their increase; but we only met with the truncatulus in one of these small pools.

It would have been of considerable scientific interest (if we could have had technical examination by an expert) to find whether, in circumstances so congenial to pereger, the Fluke infestation was perfected in it up to maturity, which it does not appear to reach in this species of Snail as observed in captivity. But, as a coincidence at least (whether of this, or of great amount of rabbit presence), our sheep were constantly affected by rot to so serious an extent that it was stated by the bailiff he "never killed one with a sound liver."

Neither Snails nor Flukes are connected with insect life, but this one parasitic attack is given in some degree of detail as an example of the very different successive forms which some of our farm infestations go through, and also of the very different localities in which they are to be found during their progress to maturity.

The following information is abridged from the history of the Liver Fluke, recorded from his own observations by Prof. A. P. Thomas, published, vol. xix. S. S. of the Journal of the Royal Agricultural Society of England; the figures are taken from the same paper.

The Liver Fluke, Fasciola hepatica, lives in livers of various vertebrate animals, and, in this country, especially of sheep, as well as of rabbits and lares; it averages from about an inch to an inch and a 
quarter in length, and in shape may be described as not unlike a little sole, in width about half its length, flat, and largest towards the head end. At the tip of its head part is placed the mouth, in the midcile of a small sucker, and at the point where the head joins the flat body, on the lower surface, is another sucker. The colour is pale brown.
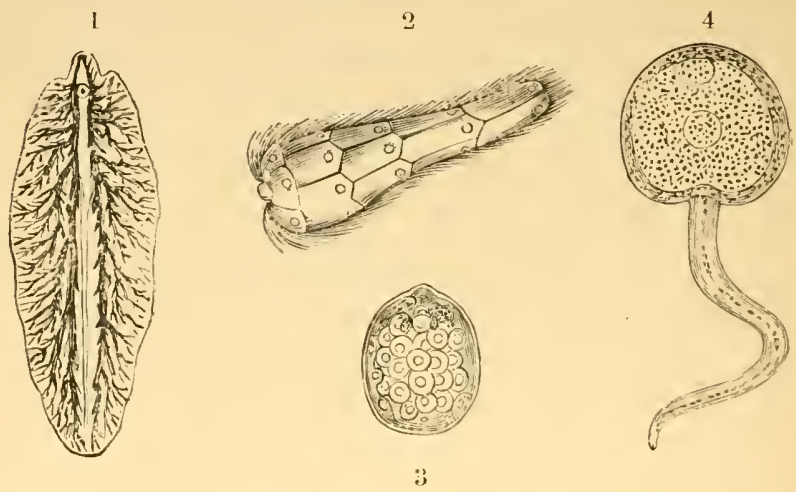

Fig. 155.--Liver Fluke in various stages: 1, Fluke, magnified, nat. length somewhat more than one inch; 2 , free embryo; 3 , "sporocyst"; 4, tailed larva, or "cercaria" : all magnified.

The eggs, which are brownish and excessively minute, are passed down from the liver to the intestines, and thus distributed with the droppings of the infested animals. If the egres fall in favourable circumstances for hatching (that is, warm weather on wet or marshy ground, or are washed into ditches or ponds), the embryo within develops in a period which may be of from two or three weelis to two or three months, according to temperature; then the contained embryo pushes off one end of the egg-shell, and swims away with great rapidity and activity.

This embryo is described by Prof. A. P. Thomas, in his minutely recorded olservations from life of this infestation, as being only about 1-200th of an inch in 
length, that is, almost too minute to be visible to the naked eye, and in shape not unlike a sugar loaf. In the centre of the largest end is a peg-like projection which is used as a boring tool, and can be withdrawn, or greatly thrust out, at pleasure.

The embryo darts and circles about in the water, large end foremost; and if in the course of its movements it meets with the Water Snail (Limneus truncatulus), it at once commences operations. It inserts its borer, and, spinning round and round on itself in the water so as to work the point in like a centre-bit, squeezes its way into the substance of the snail. Here the embryo settles into almost still life, and changes into an oval form, which, when complete, is known as a sporo-cyst, that is, a "cyst," or a bag, or bladder, of germs. Within this bag, so to call it, about ten germs develop, known as "rediæ." * Each redia as it is developed makes its way out of the sporocyst, and being furnished with a moutl and intestine, and two projections that answer the purpose of legs, it feeds on, and makes its way about within, the body of the snail.

Up to this point it will be seen there are four distinct stages of Fluke life, - the egg; the free swimming embryo ; the quiet form of the sporo-cyst, altering to a mere bag of developing germs; and the germs called redix, free from the bag, and feeding on the Suail, which ultimately (for the most part) sinks under the parasitic attack.

Continuing the history from the same observations, it is shown that in each of these rediae there form (as in the sporo-cyst before mentioned) a number of germs, but different to these in shape. The germs (the rediae) that formed in the sporo-cyst are long and narrow, about the sixteenth of in inch in length, and about one-fifth of their length in width; but the

* 'This name is given after the Italian anatomist, Redi, see Prof. Thomas's paper previously referred to. 
germs which form within the rediæ are exceedingly like Tadpoles (see Fig. 155, p. 208); they are oval and flat, and furnished with long slender tails more than twice the length of the body.

These "Fluke Tadpoles," so to call them, are technically called cercariæ, meaning animals with tails. On the escape of each cercaria from the rediæ in which it was formed, it makes its way from the body of the Snail into the water (if in a pond or ditch), but shortly attaches itself to water plants or whatever may be accessible. There it draws itself up into a round ball, exudes a gummy secretion, wags its tail violently, till at last the appendage, which has now ceased to be useful, is thrown off, and the gummy substance hardening, the cercaria remains within the covering as a little white spot on the plants, or on the locality to which it has attached itself.

It is mentioned, however, by Prof. Thomas that "if the infested Snails are crawling on the margin of a ditch or over a damp field, the cercarix, on leaving the Snail, at once proceed to form their envelopes or eysts at the bottom of the grass, and so attach themselves to the stalks or leaves near the roots."

The next step completes the circle of infestation. When the grass, to which the white speck-like cysts containing the young Liver Flukes adhere, is eaten by the sheep, or other suitable hosts (as rabbits or hares, \&c.), the young Fluke comes out of the covering, and passes to the liver of its host, increasing in bulk, after being swallowed, from about the eightieth of an inch, to the adult length of an inch or an inch and a third.

In the above note I have conveyed to the best of my power a sufficient abstract of the most important points in Prof. 'I'homas's paper to give the ordinary life-history of the linke, and in so doing I trust I shall not be considered as appropriating unjustifiably, the subject being one which ean only be dealt with by a specialist, l'rofessor 'I'homis's paper being well 
known as the record of exhaustive as well as recent observations, and also observations taken in this country. Those who wish to study the subject in detail are referred to works quoted at foot.*

Amongst methods of prevention and remedy mentioned by Prof. Thomas are the following:-

"Care must be taken to aroid introducing eggs of the Flulie, either with manure, or with fluked sheep, or in any other way. Pabbits and hares must not be allowed to introduce the eggs."

"Dressings of lime, or salt, should be spread over the ground at the proper seasons, to destroy the embryos; the cysts of the Fluke; and also the Snail, which acts as "host.",

"Sheep must not be allowerl to graze closely, for the more closely they graze, the more Fluke germs will they pick up."

"When sheep are allowed to graze on dangerous ground, they shonld have a daily allowance of salt, and a little dry food." - (Page 304 of Report previously quoted in vol. xix. of Journal of Royal Ag. Society.)

Amongst the details of treatment, of which the above is an abstract, is the observation (p. 300):"The freedom from rot of sheep feeding on salt

* 'Reports on Experiments on the development of the Liver Fluke, Fasciola hepatica,' by A. P. Thomas, F.L.S., \&c., in vols. xvii. xviii. and xix, of the 'Journal of the Royal Agricultural Society of England,' $2 \mathrm{nd}$ series.

The Life-history of the Liver Fluke is also given by the same observer in the 'Quarterly Journal of Microscopical Science,' $1883, \mathrm{pp}$. $99-133$.

The life-history, from personal observations by Ri. Lenckart, will be found in 'Zoologischer Auzieger,' Dec. 12th, 18sl, and ()ct. 'th, 18s2; and technical information regarding the development of the 'Trematorla, to which order of Iermes the Fluke belongs, will be found, with some special observations on I. hepaticum, in the 'Text-book of Zoology,' by Claus and Sedgwick, vol. i. pp. 31ti-322.

A very serviceable account, for practical purposes, compiled from various sources, will be found at pp. 127-134 of Animal I'arasites of the Sheep,' by Cooper Curtice, D.V.S., M.D., publishe t by the U. S. Dept. of Agriculture. This accunt is mainly compled from various European authorities (duly acknowledged), the infestation beino: comparatively unknown in the United States. 
marshes is well known, and is now shown to be due. to the poisonous action of the salt on the embryos, sporo-cyst, redia, cercaria, and cyst, and to its similar. action on Limnrens truncatulus itself. Even a weak solution of salt in water (containing only $\frac{3}{4}$ per cent. of salt) proves fatal to this Snail."

This principle of prevention would be especially applicable where (as in the instance, before mentioned, in West Gloucestershire) it was the custom to have exceedingly small ponds or cisterns of mason worls open to the field on one side, and very shallow, and only a few yards square. From the immense quantity of weed or grass growth in or at the edges of these socalled "cattle drinlis," and sometimes tle quantity of mud (which is stated to be the especial place of deposit of spawn of the Limncens truncutulus), there was every circumstance that was good for shelter, or propagation, of either truncatulus or pereger; and in circumstances like these a very small outlay on salt would carry destruction with it to the Snails and the Fluke embryos in the water.

Clearing the various vegetable trash, and sprinkling. some salt on the mud and into the water, would cost little, and from the details given would, in many cases, strilie in embryo at infestation which presently, when dispersed over the field, would be far more difficult to. deal with.

Stem Eelworms (Tylenchus derastatrix). - It has only been in the course of the last few yeurs that the damage caused by the Tylenchus devastutrix, a minute nematoid or thread-worm, which infests the tissues of some crop plants, and of many common field weeds, has been thoroughly brought under observation in this. country. Amongst the crops most observably infested here are Oats and Clover; Wheat is sometimes infested, and so are Beans; 'l'urnips are liable to receive infestation when subjected to it experimentally, but not (so far as lias been reported) as an evil practically. On the Continent, liye is especially subject to 
attack; Buck-wheat also suffer's; and in Holland both Onions and Hyacinths suffer much from the infestation; Potatoes also are liable to the attack. Amongst common meadow or field weeds, also liable to infestation of this Stem Eelworm, are the Daisy, the common Buttercup, the Ribwort-Plantain, Sowthistle, Shepherd's Cress, \&c.; and amongst grasses, the Annual

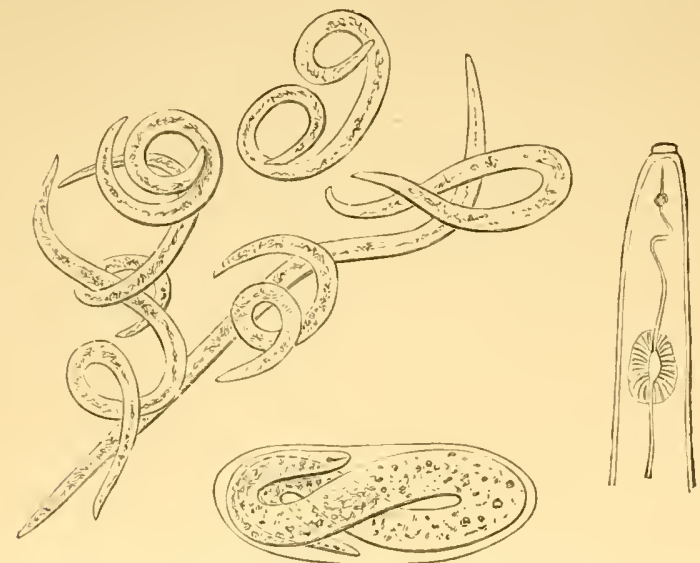

FIG. 156.- Sten Eelworm (Tylenchus devastatrix); anterior portion of female showing mouth-spear; and embryo in ers; all greatly masnified (anterior portion mag. 140 times). From figures by Dr. J. Ritzema Bos.

Pon, the Meadow Soft-grass, and the Sweet Ternalgriass.

In various linds of Eelworm attack, and especially in some kinds of infestation by Stem Eelworms, the mesence of the pest may be known by the ordinary growth of the stem, or shoot, or buts, being altered into a form so definitely characterised that this peculiar growth may be taken as a mrof of the Eelworm being within, and the attack is often named from the appearance of the diseased growtl. Thus Oat attack is lnown as "Tulip-root" (see Fig. 159, p. 216), 
or sometimes as "Segging," because the lower part of the infested stem of the Oat plant is often swelled like a Tulip-bulb, and also the leaves of the plant are often waved at the edges, and thickened like those of the Sedge, hence the term of segging or sedging. In Carnations the term "Pine-apple disease" has been given to the effects of this infestation, consequent on it so altering the method of growth as to cause the infested shoots to resemble the top of a Pine Apple. In the case of the alteration of the shape and colour of Wheat

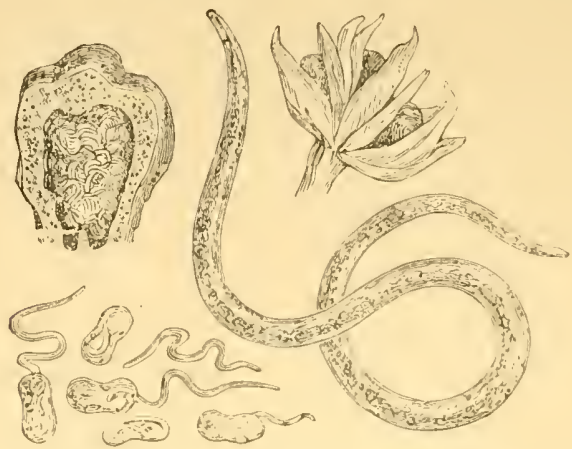

Fri. 15i.-Wormlets escaping from eggs ; section of Purples, False Ergot, or Cockle-gall, with wormlets within; after Braner's figs. (much magnified). Spikelet of Wheat, with galls (magnified). T. irilic $i$ wormlet (greatly magnified). Nat. length of largest one-serenth to one-fourth inch.

grains from presence of another lind of Tylenchus (the 'T'. tritici, see Fig. 157), the names of False Ergot and Purples are amongst those given to the attack; and in the case of a rery peculiar growth, resembling nothing so much as a little Cauliflower, which is formed on Strawbery plants, consequent on the presence of two newly observed species of Helworms of the genus Apluelenchus, the name of Caulitlower disease has been chosen to distinguish the attack.

T'his principle of naming is of considerable practical importance. Where an English name is, or can be, 
so appropriately applied to the effects of an infestation on any crop that it thoroughly describes its appearance, and at the same time is not applicable to any other kind, it is very desirable that this name should be used. And in the case of Eelworm presence, where the wormlets are so small that it requires powerful
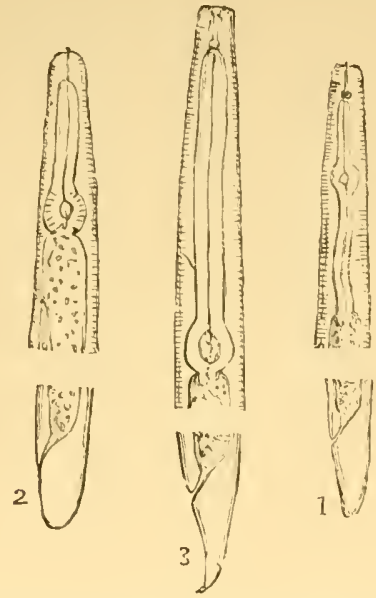

G. 158.-1, Tylenchus obtusus; 2, Aphclenchus arena; 3, Plectus oltusus, of Bastian (all enormously magnified).*

magnifiers to see them at all, it is very important to be able to tell by some well-defined external sign what kind of internal infestation is causing the mischief.

The Tylenchus derastatrix is chiefly hurtful, in this country, to Oat and Clover plants. 'The wormlets (see Fig. 156, p. 213) are excessively minute white worms; at their full growth they are not more than about one trenty-fiftl part of an inch in length, and of an

* The three species of Eelworms represented above are copjed from the figures by Dr. H. Charlton Bastian, F.IR.S., \&.e., given in l'late X. of his "Monograph on the Anguillulide," published in vol. xxv. of the 'Transactions' of the Linncan Society. 
excessive slenderness that cannot be conveyed by com monly intelligible terms of measurement. Males, females, young wormlets, and eggs, may be found together in the infested shoots.

These Eelworms belong to the family of the Anguillulide, of the order Nematoda, or "Threadworms"; and of these Anguillulide, there are many genera or divisions, as they may be called. These are distinguishable from each other in part by the form

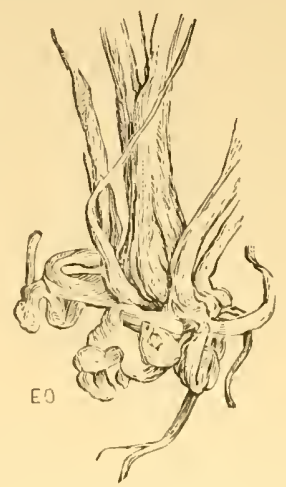

FIG. 15\%.- "Tulip-rooted" Oat-plant.

of the esophagus or gullet, and also by the presence, or absence, of a point, lnown as a "spear," in the opening of the mouth cavity. The figure (preceding page) shows some of these distinctions; it will be observed that at 1 there is a spear with a large base; at 2 , a spear without a large base ; and at 3 , there is no obvious spear. 'These distinctions, however', and the other's which are figured, are totally invisible without a powerful magnifier. It will be noticed that the figure only gives a portion of the head and tail ends; if the whole was represented, the wormlet would have to be shown (at its plesent magnified width) as from at least eight or nine inclies to a foot iong.

Returning now to the infestation of Stem Eelworm. In the case of 'l'ulip-rooted Oats, there are usually, as 
shown in the accompanying figure (Fig. 159), a number of short, stunted, pale-coloured shoots, each shoot being crumpled and folded on itself at the base of the stem. This peculiar growth, especially when joined to that of the Sedge-like form of leaves previously described, may be taken as a sign of the presence of the $T$. decastatrix in Oat plants.

In the form of Clover-sickness caused by this same Eelworm, the stallis and branches were shorter and thicker, and the buds especially much thicker, than in the healthy condition of Clover growth. This I have found to be the case in April. In speciinens examined during July, I have found the peculiar form of diseased growth more marked. There were a large number of short barren shoots about an inch long, oval in shape, with the distorted growth of leaves, forming an imbricated or tile-like exterior. These shoots were placed closely togetler; sometimes as many as five grew on an inch length of stem, one at the end, and two at each side below, so as to form together a flat fan-like mass.

They were commonly irregularly and somewhat oval or bulb-shaped; sometimes much lengthened, so as to resemble what is known as a "ducli-necked" Onion; and sometimes the lower part of the floweringstem was enlarged for an inch or two at the base. Here, as well as with "Tulip-rooted" Oat plants, the inside of the infested stem might he found hollow near the base, and with decayed matter, or palish brown powdery or granular matter, witlin.

It is to be remembered that in this brown gramular matter, and also in withering and dyiug parts of plants suffering from 'Tylenchus attack, it is not at all unusual to find other kinds of Eelworms present, which have nothing at all to do with causing diseased growth. One of the special distinctions of the 'Tylenchi is the presence of a spear on a trilobed base, which is placed in the mouth cavity.

In the case of attack of this same kind of Eelworm 
(Tylenchus devastatrix) to field Bean plants, the general effect of the attack, so far as I have observed it, is to cause a more or less stunted and deformed growth in both the plants and the seed-pods.

In a parcel of specimens sent, amongst which one: healthy plant, over three and a half feet high, gave a. kind of scale of what the growth should have been, one diseased plant was hardly four inches in height, with the stem flattened and widened and swelled at the base, and two others were only about ten inches high. In one instance there were about eight sideshoots from six inches length of main stem, these so placed that the whole plant with its shoots and pods had a kind of oval fan shape. Some of the pods were straight and rightly shaped, but a large proportion of them were stunted and distorted, and some of them were scarcely as much as three-quarters of an inch in length. The lower part of the thickened stem was much curved; and in the case of another of the plants, the stem was so miuch eurved just at the ground level that (although it was altogether scarcely more than twelve inches high) about three inches of the length was nearly horizontal.

From the above descriptions of the alterations of forms of growth which are to be found accompanying Stem Eelworm presence, in three very distinctly different linds of crops, it will be seen that these are quite sufficiently characteristic to enable any ordinary observer to juige, from external appearance alone, whether this kind of Eelworm infestation is present. It will be noticed that there is frequently a stunted, but at the same time a swelled, growth of the stem, and that this often bears on its abnormally short length as many, or nearly as many, buts or shoots (probably distorted) as would have been developed in healthy growth on the normal length of stem; also that there is a tendency to a swelling, or bulb-like formation, at the base of the stem, which is especially observable in the case of attack to Oat plants, and this bulb-like 
or oval form of distortion is often taken by the enlarged buds, or shortened shoots of Clover, suffering under "stem-sickness." Other symptoms will be found present, but the above are some of the most observable in cereals, or the common crop plants named. As we do not appear to suffer seriously from this attack to other kinds of crops in this country, it is not necessary to enter on these.

The principles of prevention are very simple, and lie mainly: 1stly, in the knowledge of the enormous vital powers of these wormlets; 2ndly, that they are to be found both in the harvested crop, and also in great numbers in the surface soil of the infested field; and 3rdly, that one kind of crop liable to attack will (or can) talie the infestation, if sowed in succession to infested plants.

With regard to the first and second points, these Tylenchi may be carried from the field in Oat straw, or Bean haulm, and may be quite uninjured in this whilst it is being used for litter. Thus in due season, in the form of farm manure, the Eelworms may be carted back again to the land. Infestation may similarly be spread by infested Clover hay thrown for fodder, but not to the same extent, for only a portion of "stem-sick" Clover yrous loug enumgh to cut. Also, if lept in a dry state, Tylenchi will regain their vital power's on being moistened.

Consequently, manure male from infested fodiler, whether straw, Clover, or other plants, ought not to be carried to fields where crops are to be grown which are liable to attack. Likewise it is desirable to collect and burn the stnbble remaining on the ground, in order to destroy in it all the wormlets which may have remained, and also all the Tylenchus eggs.

With regard to presence of the Eelworms in the land, one of the best remedies consists in very deep plonghing, so that the upper layer of earth, with the contained Anguillulicle, may lie well buried down. Or a plough witl skim-coulter attached may do the work 
very serviceably, as it is mainly in the surface of the land that the wormlets, which have left the plants as they matured, lie. This treatment should be carried out in autumn, and (if the next crop is of a kind liable to infestation), in the next spring cultivation, rich manure given to the crop. It is most desirable that this should not be of stable manure, which, it is very possible, may contain Eelworms, but rather of guano and superphosphate.

The point that one kind of crop (liable to infestation) may take it from preceding Stem Eelworm presence is very important.

Clover after 'Tulip-root, or Oats after stem-sicli Clover, should be most carefully avoided. Barley appears to be perfectly free from infestation, therefore is useful in rotation.

Special applications which liave been found most serviceable as manure in the preparation of the land, or as dressings to bring an infested crop over attack, are sulphate of potash alone, or, as a mixture, with sulphate of ammonia and phospliates.

In one special case reported of Tulip-rooted Oats in Millothian, in 1888, a top-dressing of about 1 cwt. per acre of sulphate of potash was given, with the result that the disease disappeared, and an excellent crop was cut.

In another instance regarding 'Tulip-rooted Oats (in fields from which specimens of stem-sick Clover had been sent me in the previous year) the manure applied consisted of plrospluates, ammonia, and potash, when sown, at the rate of 3 cwt. per acre. 'This produced a very luxuriant growth, with the exception of a sandy knoll. These knolls are noted as being especially subject to 'T'ulip-root.

As a remerly for "Clover sickness," produced by Eelworms, the experiments of Mr.J.J. Willis, at Tothamsted, Herts, have shown the application of a mixture of sulphate of potaslı, 3 ewt., and sulphate of ammonia, 1 cwt., per acre, to have an excellent 
effect both in checking the disease, and throwing the crop into lasting good growth. This was applied early in April. Sulphate of iron, at the rate of 2 cwt. the acre, also answered well, though not so markedly in pushing on good growth of the second crop.

The above motes give some of the main points regarding Stem Eelworm attack in Britain, taken mainly from observations placed in my hands by my contributors; and besides our own observations, I have to mention, with most hearty thanks, the constant and invaluable assistance I have received in my researches, from their commencement in 1886, from Dr. J. Ritzema Bos, Prof. at the State Agricultural College, Wageningen, Netherlands. To his identification of specimens I have repeatedly owed the certainty as to the nature of the Tylenchus, or other Eelworm infestations of less hurtful nature present, which could only be trustworthily given by a specialist. Without this assistance it would have been impossible for me to work the subject forward, and I beg to offer my sincere thanks and full acknowledgment of his valuable and never-failing aid.*

Fig. 160 (p. 222) gives a few examples of an order not of insects, but of creatures so much resembling: insects in their larral stage, both in appearance and habits, that they are often taken for insect infestations, and one name by which they are known is that of "False Wireworms." These Julus worms, or Snake Millepedes, belong, like the well-known Centipedes, to the order Myriapodu (or " many-footed "), very nearly"

* For details of the history of the Tylenchus derastatrix, together. with excellent plates, sec 'L'Anguillule de la 'Tige (Tylenchus derastutrix),' par Dr. J. Litzema Bos, Prof. à l'Institut Agrieole de l'Etat i Wageningen, Haarlem, pt. I. 1888, pt. II. 188\%. Also, by the same writer, 'Annotations, deuxieme series,' Haarlem, 1891, this being a most useful addition, practically as well as scientifically, embodying much information on our British as well as Continental attacks.

My own records of observation are eontained in my Annual lieports on Injurious Insects from 1886 to 1890 , being the loth to. 14 th Reports, inclusive. 
allied to insects, as they are formed of a succession of rings, and breatle by means of trachea, but differ from them in having much the same appearance throughout their lives, and (markedly) in never having wings.

I'hey are stated to feed on decaying as well as living animal substances, such as small worms, slugs, and grubs; as well as on decaying and living vegetables; and one or other of the various linds attack

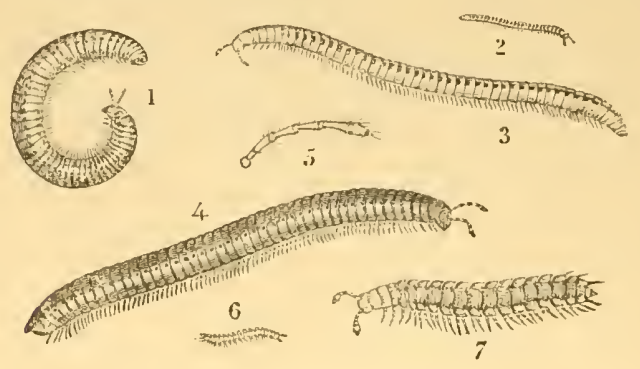

Fig. 160.-Millepedes: 1, Julus londinensis; 3, J. guttatus (pulchellus), Teach; 4, J.terrestris; 5 , horn; 7, Polydesmuts complanatus; all magnified; ( 2 and 6 , nat. size of 3 and 7 ).

Carrots and Potatoes, Cabbage roots, and roots of Kidney Beans, as well as roots of other crops grown in gardens; and also are sometimes found in great numbers at the roots of Wheat.

The females lay their eggs in the ground from Christmas until May, and the young Julide live two years before they are perfect, during which time they grow and change their skins five times, but remain (as observed above) the same in aplearance, excepting in increase of the number of the legs.

'lhe kind linown as the London Snake-millepede (1, Fig. 160), from having been specially observed near London, has, when perfect, about $\mathbf{1 6 0}$ legs, placed in two pairs on each segment.

Snalie-milleperles are to be found under clods of 
earth and stones, and under rubbish, such as bricks and pieces of wood, as well as in moss, or under bark; and I have found the flattened Snake-millepedes in heaps of leaves blown together by the wind; also they are said to propagate most freely in undisturbed ground. Therefore it would appear that thorough cultivation of the land, removing rotten roots from infested ground, and also removing all the rubbish under which they shelter, would be good treatment; likewise good dressings of fresh gas-lime on infested ground could not fail to be of service.

Julus terrestris and $J$. londinensis, figured p. 222, are of a dark lead or pitchy colour; the $J$. pulchellus is also cylindrical, but is much smaller, and of a white or ochreous colour, and when magnified will be seen to have a double row of erimson spots along each side, excepting on the four first and five last segments. From these it talies its name of guttutus, or "spotted" Millepede. After death the colour changes to a general tint of red puryle. This Millepede is excessively fond of Mangolds, and the taste may be serviceably turned to account by using slices of Mangolds as traps. Cotton calie will also attract them from attacked crops. Salt or nitrate of soda in solution will kill this kind of Millepede rapidly, but when applied so as only to dissolve gradually into the soil does not appear to do them harm.

The Polydesmus complanatus, or "Hattened Millepede," is distinguishable by being flattened on the back, and by being a little dilated at the sides. It is of a lilac or greyish colour above, whitish below, and lias the back granulated. It is stated to be similar in its habits to the Snake Millepedes.

Acarina, or "Mites,"- of which the "Spinning Nite," commonly linown as the Red Spider of Hops; the Harvest Mites; and Tyroryyhus Inngior, figured p. 224, a Nite found in hay, are fumiliar examples,form one of the orters of the class Araclenidu, which includes the true Spiders, Mites, Scorpions, \&c. 
One of the chief characteristics of this class is that the head and fore body (thorax) are almost always joined or "fused" into one piece, known as the cephalothorax. In the Spiders the abdomen is joined to this cephalo-thorax by a short stalk, something in the same manner as the abdomen of a Wasp is joined to the fore body; but in the Acarina, or Mites (with which we have much more to (lo agriculturally), this is not so; the head, thorax, and abdomen are fused, or joined

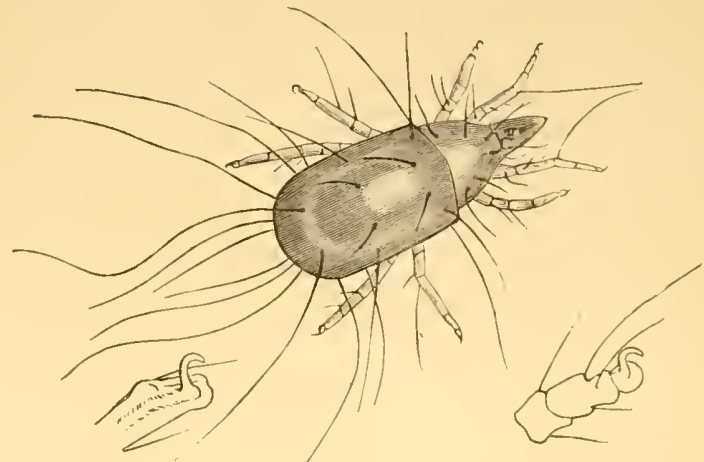

FIG. 161.-Tyroglyphus longior (from fig. by Fumoze and Robin): claw and sucker, right-hand side (from Murray's 'Aptera') ; claw and sucker on left-hand side, figured by Ew. from life: all magnified. Nat. length rather more than half the 25 th of an inch.

into one continuous mass (see Fig. 161). As a rule, all Mites when mature have four pairs of legs, excepting the "Gall Mites," or Phytopti, which have only two pairs. These Phyjtopti hatch out of the egg (as they continue) with two pairs, but usually the young of the Acarina are stated to hatch with only three pairs of legs.

The Mites are much too various in their habits and structural details to allow of entering on these points here.

The "Red Spider" ('T'etrunychns telarins), though hardly large enough to be seen with the naked eye, is 
a constant trouble, both in gardens and Hop grounds. It spins a fine web over the leaves or other parts of the plant it attacks, and amongst these threads it fastens its eggs, and under their shelter the young Red Spiders are protected.

The worst attacks of these Mites take place in dry seasons; and one desirable remedy is considered to be washing the infested plants with soft-soap, applied by
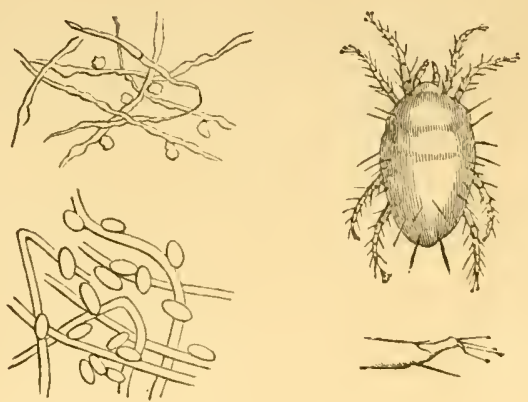

Frg. 112.- -Red Spider, eggs and web (moist and dry); all greatly magnified.

means of field washing engines, or lesser power, as may be requisite.

During winter the Red Spider shelters in crannies, under stones or clods, in cracks in Hop-poles, or, in fact, in any convenient nook; and where it is present to a very injurious extent on wall trees, I liave found that rubbing the bark thoroughly with soft-soap, or applying a mixture of gas-lime and soft-soap thoroughly, but not roughly, rubbed on by hand, did great good. A good dressing of gas-lime was also laid in a line at the bottom of the wall to keep the Mite from crawling up, and thus the trees were cured. Sufficient moisture to ensure a vigorous growth appears an important means of prevention of attack. 
The little dark red Acari, lilie small crimson Spiders in shape, and large enough to be clearly distinguished without the help of magnifiers, are often to be found in vast quantities on bark of various kinds of orchard trees in spring. For attacks of this sort scraping the bark so that there may be as little shelter as possible for small vermin of any kind in its crannies, is one very good measure of prevention. As a remedy washing or syringing with a mixture of soft-soap and sulphur is very useful, and probably the mixture sold under the name of the "Chiswick Compound," by the Chiswick Soap Co., Chiswick, Middlesex, would answer well, as a very similar one has long been known to do in South Australian practice. There is difficulty without special care and mixture of ingredients in dissolving sulphur in soft-soap wash, but in the above mixture I find it becomes thoroughly dissolved in about sixteen hours after being diluted to the desired point for safe application with water.

The Gall Mites, or Phytopti, give us an example of

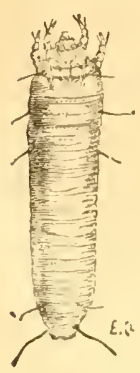

FIG. 163. yet another form. These (see Fig. 163), it will be seen, are of a cylindrical shape, and also have only two pairs of legs. They give rise to various linds of malformations of growth, as the bunches of deformed twigs on Birch trees, sometimes two or three feet in diameter, popularly known as Witches' Brooms; also the crimson spikelike growth often seen on the surface of Sycamore leaves, and various other forms of which one of the most injurious to fruitgrowers is knob-like diseased growth of Black Currant buds, caused by the Black Currant Gall Mite, the Phytoptus ribis.

The foregoing short notes of some very specially injurious linds of farm or orchard pests are not placed in technical scientific sequence, but are simply given in order to lay before the reader some of the chief points in which these Slugs, or Mites, or Millepedes, 
or Eelworms differ from true insects, and how (similarly to insects) by a knowledge of their habits and life-history, we may apply serviceable remedial measures.

In each case, however, I have given the scientific name of the order or division to which these noninsect pests belong, and their sequence in classification of the animal lingdom may be fairly given as follows. I say fairly, for schemes of classification differ, and also only a few oriters are here entered on, so that while some of those mentioned follow each other in sequence, there are in other cases many intervening between.

At the head of the animal kingdom stand the vertebrata, the back-boned animals with which here we have nothing to do. Lower in the scale, and highest of those in the preceding short notices, are :-

1. Molluscs, represented here by Snails and Slugs, pp. 198, 20t-207.

2. Insecta.-Insects, the various orders of which class as Flies, Beetles, \&c., are the main subject of this little book, pp. 1-197.

3. Myriapoda, including "Julus-worms," or Millepedes, pp. 221-223.

4. Arachnicla, the class which includes Spiders, Mites, Scorpions, \&c. ; represented here by some of the Acarina, or " Mites," pp. 223-226.

Then, missing all mention of various important divisions, notably that of the Crustacea which are little represented in agricultural attack, we come to the lower order of :-

5. Nematodes, or Thread-worm, including various kinds of Anguillulide, or Eelworms, pp. 212-221.

6. Trematodes, parasitic pests, amongst which is included the Fasciola hepatica= Distomum hepaticum, the Liver Fluke of the sheep, pp. 207-212.

And now, once again, with regard to the subject of this little book, I wish to point out that power of prevention of insect attack does not lie in the mere 
knowledge which may enable us to tell the name of an insect, but in the knowledge of its habits, which will suggest to the practical agriculturist, in many cases, how to counteract these directly by measures of husbandry; or indirectly, how, if we cannot get rid of the attackers, we may at least carry the crop through attack.

I trust that, though the foregoing observations are but a slight fragment compared to the mass of information that is needed, they may be, at least to some extent, useful; and it would be the greatest gratification to me if they should in any degree induce others to take up the work more competently than myself. And in this view I will venture to give my own ideas in the words of one of our greatest thinkers:- $-\mathrm{He}$ who would thrive in serviceable study "must, as with one eye, survey the natures of things, and have the other turned towards human usEs." 


\section{GLOSSARY.}

Ala.-Wings.

Alate.-Winged.

Alula.-Small membranous appendage to the base of the hinder edge of the wings of Diptera (two-winged flies).

Antenna.- "Horns" or "cranial feelers" placed in front of the head; various in form, sometimes thread-like, and longer than the insect; sometimes elbowed; with a club of leaves; or sawlike, feathery, or of many other forms; in butterflies somewhat like pins.

Apterons. - Without wings.

Cauda.-Tail.

Caudal prolegs.-Sucker-feet attached to the tail-segment of many kinds of larve.

Chrysalis.-A term applied to the pupal or inactive stage of life of various insects, chiefly butterflies and moths.

Clypeus.-Portion of the front of the face above the upper lip.

Cocoon.-A case, formed of silk or other materials by various kinds of larva, commonly for protection whilst they change to pupce.

Coxa.-The hip; the first chief division of the legs of perfect insects, between the thorax and the thigh or femur.

Elytra.-Horny wing-cases-term commonly applied to the upper wings of beetles.

Eyes, compound.-The common form placed on each side of the head, and composed of a large number of separate eyes or lenses placed side by side.

Eycs, simple.-Ocelli; minute single eyes placed on the crown of the head.

Fcelers.-Palpi; small appendages on the lower jaws and lower lip.

Femur, plural Femora.-CThigh; second chief division of the leg.

Halteres.-Poisers; short appendages, often like slender pins, to be found in two-winged flies, taking place of the absent lind wings.

Haustellum.-Term applied to different kinds of insect-mouths formed for suction.

IIorns.-Antenna; organs of various shape placed on front of head. 
Imago.-Insect in perfectly-developed stage, as butterfly, fly, beetle, \&c.

Labium.-Lower lip.

Labrum.--Upper lip; this is placed vertically over the lower lip, with the two pairs of jaws placed horizontally between the two lips.

Larva.-First active stage of insect life, as caterpillar, maggot, \&c.

Legs.-In the perfect insect, formed of four chief pieces,-hip (coxa), thigh (femur), shank (tilia), and foot (tarsus); with a small piece, called the trochanter, between the hip and thigh. In larvæ, short legs of various forms, and sucker feet, or prolegs.

Mandibles.-Upper jaws, placed horizontally opposite each other beneath the upper lip.

Mlaxille.-Lower jaws, placed similarly to the above, just below the. "mandibles," and furnished with feelers; thence called feelerjaws.

Maxillary palpi.-Feelers on the lower jaws.

Mouth.-Formed of six pieces, an upper lip (labrum), lower lip. (labium), with two pairs of jaws opposed horizontally between them, of which the upper pair (mandibles) are often strong, and serve for biting with; the lower pair (maxille, or feeler-jaws) are usually smaller and weaker, and are furnished with feeler's or palpi, as is also the labium. In butterflies, Aphides, ic., that have sucker-mouths, some of the above-mentioned portions are variously altered in shape.-See Proboscis.

Ocelli.-Minute single eyes, usually three in number, fixed on the crown of the head, commonly known as simple eyes.

Oviparous.-Producing eggs.

Ovipositor.-Instrument whereby the female insect lays her eggs.

Ovum.-Egg.

Palpi.-Feelers, placed on the lower jaws and lower lip.

Poisers (see Halteres).-Appendages in the place of the hinder wings of the Diptera.

Probositis.-In butterflies, altered lower jaws forming the spiral trunk; in two-winged flies, the altered lower lp enclosing the piercers.

Prolegs.-Sucker-fect, whereby caterpillars and other larve hold firmly to the substance they are placed on.

Pulvilli.-Cushions beneath the feet of flies, and some other insects.

Pupa.-Second stage of insect life, in which it is often inactive, as with the chrysalis of butterflies.

Rostrum.-Sometimes called snout, when applied to the prolonged front of the head of some kinds of beetles; also used as well as proboscis for the altered labium of Aphides.

Scutellum.-A name sometimes applied to a portion of each segment of the thorax, but especially to the triangular shield-shaped plate. between the base of the wing-cases in beetles and bugs. 
Segments.-Rings of which an insect is composed-considered to be thirteen, including the head.

Spiracles.-Breathing-pores for the most part placed along the sides of insects, or at the end of the tail, by means of which the air is drawn into or expelled from the trachce, or breathing-tubes.

Stigma.-A small thickened spot on the front edge of the fore wing of various kinds of insects.

Sucker-feet.-Prolegs; fleshy appendages, whereby larva hold firmly to the twigs, \&c., whereon they are placed.

Tarsi.-Feet, the fourth chief division of the leg; being that on which the insect rests.

Telum.-Last segment of the abdomen.

Thorax.-The three segments next to the head, known respectively as the pro-, mcso-, and meta-thorax, of which in perfect insects the first bears a pair of legs, the other two each a pair of legs and wings.

Tibia.-Shank; third chief piece of the leg; between the thigh (femur) and foot (tarsus).

Trachece-Organs of respiration communicating with the air by breathing-pores (spiracles), and conveying it by means of smaller tubes throughout the body.

Trochanter.-A very small portion of the leg placed between the hip and the thigh.

Ungues.-Claws, or curved hooks, at the extremity of the foot.

Viviparous.-Producing living young. 



\section{IN D E X.}

A.

Acarina, 223-226; characteristics of the class, 224

Aceto-arsenite of copper, 140

Acherontia atropos, 127

Aculeata, 165

Agrotis exclamationis, 141

", segetum, 141

Aleyrodes proletella, 189

Alkali waste, 92,93

American blight Aphis, 183-185; action of, on bark, 184

"Anbury," 110

Anguillulidæ (Figs.), 215, 216

Anisopteryx æscularia, 137

Anthomyia ceparum, 49 ,, radicum, 53,54

Anthonomus pomorum, 104

Aphaniptera, 28, 78, 80

Aphides, $172-175,188$; to distinguish tribes of, by nervures of wings, 176,177

Aphidinæ, life-history of, 177

Apion apricans, 107

Apple-blossom Weevil, 104

Apple Mussel Scale, 189, 190

Apple Sawtly, 154; difference between caterpillar of, and that of Codlin Moth, 155; remedies for, 155

Apple-suckers, 174

Arachnida, 227

Aromia moschata, 114

Ash-bark Beetle, 113

Aspidiotus conchiformis ( = Mytilaspis pomorum), 189, 190

Athalia spinarum, 154
B.

Balaninus nucum, 103

Barley Bug, 190, 191

Bean Aphis, to destroy, 179

Bean-seed Beetles, 108; dressing to destroy in seed, 109

Bee Parasites, 34, 166, 167

Beet Carrion Beetle, 88

Beetles, description of, in different stages, 81 ; main divisions classed by number of joints of the feet, $8: 2$

Birds, uses of, in clearing caterpillars, 147

"Blood-worm," 48

Bombyx (Gasteropacha) neustria, (Lackey Moth), 139

Bos, Dr. J. Ritzema, reference to his works on Tylenchus devastatrix, 221

Bostrichus dispar, 99

Brachelytra, 85

Bruchi, 108

Bush-harrowing, 39

Butterflies and Ioths, 122-148; larvie and metamorphosis of, 123,125

Byturus tomentosus, 98, 99

C.

Cabbage Butterfly, 16iz

"Noth, 142

", -root flies, 53, 54

Caterpillars, effect of weather on, 15; to destroy, in wood, 192 
various methods of destroy. ing, 133

Cattle and Stock Flies, 63-78

Cecidomyia destructor, 44-47 tritici, 42

Cephälemyia ovis, 75

Cephus pygmæus, 157

Ceutorhynchus sulcicollis, 109

Chafers, 89-93

", Garden, 89

, Golden, 89

Chalcididx, 163

Cheimatobia brumata, 135

Chermes abietis, 187

, laricis, 186

Chironomus plumosus, 48

Chlorops tæniopus, 59

Chrysalis, 17-20

Clavicornes, 86-88

Clearwing Moths, 129 ; metamorphosis of, 130

Clover-sickness, 219, 220. (See also references to Stem Eelworms)

Club in Cabbage, 110

Coccidæ, 189

Coccinellidæ, 120

Cockchafer, Common, 90 ; lifehistory of, 91

Cockle-gall, 214

Cocoons of Sawfly, to destroy, 153,155

Cold does not necessarily injure caterpillars, 143

Coleoptera, 28, 80-121

Common Vapourer Moth, 137; history of, 138

Corn Sawfly, 157 ; caterpillar has only rudimental claw-feet, 157

Cossus ligniperda, 131

Crioceris melanopa, 115

Cuckoo Fly (of Hop), 172, 173

Cucujus testaceus, 86

Cynipide, 159

Cynips Kollari, 159

D.

Daddy Longlegs, 38-42

Death's-head Moth, 127, 128
Deep ploughing as a remedy for infestation, 43

Dimera, 172

Diptera, 27, 28, 36-78

Distomum hepaticum, see Fasciola hepatica, 207

E.

Egg-laying, to prevent, 39 ; earthing up to defend from, 52

Elater lineatus and other species, 94

Elm-bark Beetle, 112

Euacanthus interruptus, 172

Euplexoptera, 32, 193

Eupoda, 115-120; how distinguishable, 115

Eyed Hawk Moth, 128

F.

False Wireworms, 221

Fasciola hepatica, 207

Fleas, 28, 78; life-history and prevention of, 79,80

Flies (Diptera), 27, 28, 36, 37 ; description of, in different stages, $37,49,77$

Forest Fly, 77

Frit Fly, 61

Frog Fly (Hop), 172, 173

, ,, (Potato), 173

Froghoppers, 172, 173

G.

Gall Mites, 226

Galls, Marble, 159 ; Spangle, 160

Gas.lime as a preventive of Cab. bage-root Fly attack, 55; uses of, 91, 92, 93, 111, 146

Gastrophilus equi, 65,66

Geodephaga, 83-85

Goat IIoth, to destroy caterpillar of, 131

"Golden Eye," 31, 167 
Gooseberry (and Currant) Sawfly, 153; prevention of, by destroying cocoons, $\&$ c., 153 , 154

Gout Fly, 59; early spring sowing a preventive of attack, 60

Ground Beetles, 83-85

Gryllotalpa vulgaris, 192

H.

Haltica (Phyllotreta) nemorum, 116

Hand-picking, methods of, and best time for, 127, 146

Hay Mite, 224

Heart and Dart Moth, 141

Hessian Fly, 44-47; flax-seeds of, 46 ; to destroy, in screenings, 47

Heteromera, 102

Heteroptera, 32, 191-193 ; distinction of, 191

Hippobosca equina, 77

Homoptera, 169-190 ; description of, 171; sections classed by number of joints of the feet, 172

Hop Aphis, 180-182; infests also Damson and Sloe, 180; migration of, 181 ; remedial measures, 182

Hop Bug (fig.), 190

Hornet, 166

Horse Bot Fly, 65; life-history of, 66

Hybernia defoliaria, 134; Mottled Umber Moth, 134 (see also means of prevention of Winter Moth, 136, 137)

Hydradephaga, 85

Hylemyia coarctata, 57,60

Hylesinus Fraxini, 113

Hymenoptera, 30, 149-168; description and metamorphosis of, $150-152$

Hypoderma bovis, $67-75$

Hyponomeuta padella (Small Ermine Moth), 138
I.

Ichneumon Fly (of Large Cabbage Butterfy), 161

Ichneumonidæ, 160-163

Insects, description of, 1-3; respiration and circulation of, 4-6; metamorphoses, $6-15$

Insects, perfect, description of, 24

\section{J.}

Jarring (or beating down) as a remedy for insect attack, 91 ; for weevils, 103 ; for orchard moth eaterpillars, 140

Julus Worms, 222, 223

K.

Knapsack Sprayer, 197

L.

Lackey Moth, 139

Ladybird Beetles, 120

Lamellicornes, 89-93

Larch Chermes, 186, 187

Larva, 11-15

Lepidoptera, 122-148

Licked Beef, 71

Limax agrestis, 201

Limnæus pereger, and L. truncatulus, 206, 207

Liver Fluke, 207, 212; life-history of, 208-210; methods of prevention of, 211,212 ; reports on (note), 211

Locusts, effects of burying of eggs of, 19.1

Longicornes, 114

"Looper" caterpillars described, 135

Lophyrus pini, 152

Losses, special, on Hop and Turnip erops, 203 
H.

Mamestra brassice, 142

Mangold and Beet Fly, 51

Manoold-feeding Beetle, 84

March Moth, 137

Meligethes æneus, 87

Melophagus ovinus, 78

Millepedes : flattened, 223 ; snake, 222,233 ; listory of, 222

Mirus dolabratus, 190, 191

, tritici, 190, 191

Mites, 223-226

Mollusca, 204-207; definition of, 204

Monomera, 172

Musk Beetle, 114

Mustard Beetle, 116, 119 ; means of prevention for, 120

N.

Necrophaga, 86-88

Nematoda, 216

Nematus ribesii, 153

Nest-making caterpillars, 138; to destroy, 139

Neuroptera, 34, 167

Nitrate of soda, 40,97

Nut Weevil, 103

o.

Oak Leaf-roller Moth, 148

(Estridæ, 64-76

(Estrus bovis (see Hypoderma bovis)

(Estrus ovis, 75

Onion Fly, 4!, 50

Orchard moth caterpillars, 133141 ; to destroy by Parisgreen, 140

Orders of insects, $27-31$; named fron number or nature of wings, 26 ; enumcrated, 27

Orgyia antiqua, 137

Ort lioptera, 34, 193

Oscinis frit, 61

Ox ('iad Fly, a blood-sucker, 63; the larva a ground feeder, $6 i$
Ox Warble Fly, 67-75; lifehistory of, $67-70$; effect of warble on surface of carcase, 71,72 ; loss from attack, on milk, \&c., 72 ; on hides, 73 ; preventive measures and remedies for, $73-75$

\section{P.}

Paris-green spraying, 140

Pea and Bean Seed Weevils, 108, 109

Pea and Bean Weevils, 105-107

Pear-shaped Weevils, 107

Phidon betulæe, 116, 119

Phorodon humuli, 180

Phytophaga, 115-120

Phytopti, 226

Pine Sawfly, 152

Plasmodiophora brassic $\rightsquigarrow, 110$

Platygaster tipulæ, 164

Polydesmus complanatus, 223

Potato Bug (fig.), 190

Principles of study of prevention of insect ravage, 199-203

Proctotrupids, 163, 164

Psylla mali, $17 \pm$

Psyllidx, 172, 173

I'teromalus puparum, and observations on, 163

Pupa, 17-23; transformation of from butterfly caterpillar, 19 , to perfect Grasshopper, 21

Pupipara, 77, 78; peculiarity of development of, 77

Ii.

Riape-cake, as a remedy for Wireworm attack, 97

Raspberry Beetle, 98, 99

Red Spider, and remedies for, 225

Ribbon-footed Corn Fly, 59

Rove Beetles, 85

Rhyncophora, 102-114

Salt, 39

S.

Scale-insects, 189 
Scolytus destructor, 112

Screenings, destruction of, as a preventive measure, 44,46

Sesia bembeciformis, 129

, tipuliformis, 130

Sheep-driving, to shake off caterpillars, 156

Sheep's Nostril Fly, history of, 75,76 ; prevention for attack of, 76

"Sheep Tick," incorrectly so called, 78

Shot-borer Beetle, 99-101

Silpha opaca, 88

Sirex, Common or Steel-blue, and Giant, 158, 159

Sitones, 105-107

Skimming the surface stubble, remedy for Pea Weevils, 107

Slime-fungus, cause of Anbury and Club, 110

Slugs, Black and Milky, 201; Arion ater, 205; principle of destruction of, 205

Small TVhite Ermine, 138

Smerinthus ocellatus, 128

Snails, Marsh or WVater, 206, 207

Snowy Fly, 189

Soft-soap mixtures, 140

Soft-soap and sulphux compound useful against Red Spider, 225

Spinning Mites, 225

Sprayer, Inapsack (Eclair, No. 1), 197

Spruce Chermes, 187

Stem Eelworms, $212-221$; plants infested by, 213; effects on plant growth, 217 ; remedies for, 219,220

Sternoxi, 93-98

Steropus madidus, 81

Strepsiptera, 34, 166, 167

Surface caterpillars, 141 ; effect of weatler on, 143 ; burying of, 143 ; remedial treatment for attach of, 143--1.47

$\mathrm{T}$.

Tabanus bovinus, $63,6 \pm$

Tar, injurious to bark, 137, 1s 1
T'arred boards to shake weevils down on, 105 ; to catch Hop Froghoppers, 173

Tetramera (Pseudo-tetramera), $102-120$

Tetranychus telarius, 225

Threadworms, 216

'Thrips, 33, 195, 196; nature of feeding apparatus of, 196 ; means of prevention of, 197

Thysanoptera, $133,195,196$

Tipula oleracea, $38-42$

Tortrix viridana, 148

Trematodes, 227

Trenching, use of, 111

Trichoptera, 3t, 167

Trimera (Pseudo-trimera), 120

Trimera (section of Homoptera), 172

Trogosita mauritanica, 86

"Tulip-root," 216 (see also references to Stem Eelworms)

Turnip Aphides, 178

, Blossom Beetles, 87

Turnip (or Dart) Moth, 141

Turnip Flea Beetles, 116-119; winter shelter and foodplants, 117; cultivation to prevent, 118 ; stimulants to support crop under attack, 119

Turnip-gall Weevil, 109, 110

Turnip Leaf-miner, 50

Turnip Sawfly, 15t-157; remcdies for, 155,157

Tylenchus devastatrix, 212, 215

, tritici, 214

Tyroglyphus longior, 224

IV.

Wecvils, 102-114

Wheat Bug, 190, 191

Wheat-bulb Fly, 57 ; after fallow, fil

Wheat Midge, 42

White Cabbage Butterflies, 12:, 124 ; methods of prevention for, 126

Wingless female moths, 135 ; to prevent ascending trees, $1: 36$ 
Winter Moth, 135; life-history of, 136; to check attack of, by sticky banding, 136,137

Wireworms, 93-98; life-history of, 94 ; to prevent egg-laying of, 95 ; preparation of ground to prevent, 96 ; found in turf and sometimes in dung, 97 ; fertilisers useful as preventives, 97
Wood Leopard Moth, 132

$\mathrm{x}$.

Xyleborus dispar, 99-101

$\mathrm{Z}$.

Zeuzera æsculi, 132

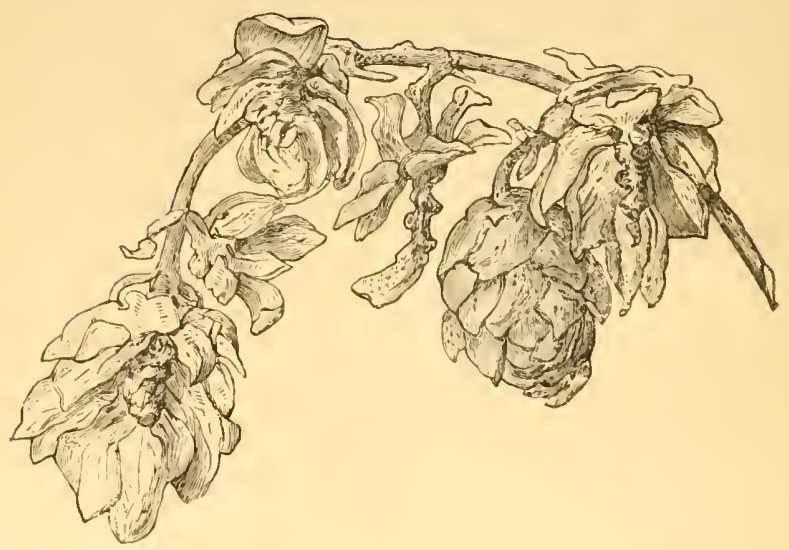

Hop-cones injured by infestation of the larva of a Cecidomyia, popularly known as the Strig Maggot. 


\section{OTHER WORKS BY THE SAME WRITER.}

\section{A MANUAL OF REMEDIES AND MEANS}

OF PREVENTION for the Attacks of Insects on Food Crops, Forest Trees, and Fruit. One vol., fully illustrated, with portrait. Demy 8vo, cloth, 5 s.

This work gives a short account of the insects commonly injurious to a serious extent in this country, with means found practically serviceable to prevent or diminish the amount of their ravages.

"A second edition of Miss Ormerod's work, highly valued by scientific agriculturists."-Times.

"Every farmer, gardener, and fruit-grower should have a copy of this excellent five-shilling Manual in his library, in order that he may know his enemies, and the best of ascertainel methods for defeating them."-Agricultural Gazette.

"The most valuable work which has been published in England on this important matter."-Bell's Weelely Messenger.

\section{A GUIDE TO METHODS OF INSECT LIPE ;} and Prevention and Remedy of Insect Ravage. Being Ten Lectures, delivered for the Institute of Agriculture, December 1883. Crown 8vo, fully illustrated, price $2 s$.

"A little volume well provided with everything that can make its contents accessible or understoo I : Illustrations, Glossary, and Index leave nothing to be desired by the student. The whole subject is treated not only with the accuracy of precise and scientific knowledge, but with the practical end always in view. The Remedies are described as well as the Attacks."-Agriculturul Gazette.

A few copies of the ABOvE WORK are still procurable. A SECOND Edition, brought up to date and much enlarged, with many additional figures, is now issued under the title of 'A Text-Book of Agricultural Entomology.'

\section{A TEXT-BOOK OF AGRICULTURAL ENTO-} MOLOGY, being a plain introduction to the classification of insects and methods of insect life, with means of prevention of insect ravage; suited for the use of agriculturists and agricultural teachers and students. One vol., pp. $238 ; 164$ figures. Crown 8vo, price 3s. $6 \mathrm{~d}$.

\section{SIMPKIN, MARSHALL, HAMILTON, KENT \& CO.} Stationers' Hall Court, London. 


\section{OTHER WORKS BY THE SAME WRITER.}

\section{REPORTS OF OBSERVATION OF INJURIOUS}

INSECTS. Royal 8vo, illustrated. For 1879 and 1880, $1 s$. each. For 1882 (with Special Report on Wirsworm) ; 1883 (with Appendix on HoP APHIS); 1884 (with Special Report on Warble Fly); 1885 (with Second Special Report on WARBLE FLY); and 1887, 1888, 1889, and 1890, each with Report on WARble FLY ; and 1891 (with Special Report on Diamond-вack Мотн) ; price $1 s .6 d$. each. The Reports for 1878 and 1881 are ont of print.

\section{THE HESSIAN FLY IN GREAT BRITAIN.}

Fully Illustrated; with Means of Prevention and Remedy. Also, The Hessian Fly in Great Britain in 1887. Crown 8vo, price $6 d$. each; 4s. per dozen; 25s. per 100.

PARIS-GREEN. Its Uses, and Methods for its Application as a Means of Destruction of Orchard Moth Caterpillars. Demy 8ro. Price 2d. each; 1s. 6d. per dozen; 8s. 6 $d$. per 100.

TURNIP FLI.-REPORT OF OBSERVATIONS IN 1881. Royal Sro, price 6 $c_{\text {. }}$; 4s. per doz.; 25s. per 100 .

WARBLE FLI. - SPECIAL REPOPTS (from 'Reports on Injurious Insects for 1884, 1888, and 1889 '). Royal 8vo, price $3 d . ; 2 s .6 d$. per dozen ; 16s. per 100.

LECTURES on the following subjects:-INJURious Insects, price $6 d$.; The Turnip Fly, price $6 d$. ; Estrid.e or Bot Flles, price $4 d$. Crown 8 vo.

OBSERVATIONS ON THE SUGAR-CANE SHOTBORER BEETLE (Ayleborts perforans). Its Habits and its recent spread in the West Indian Islands, with some suggested measures of Prevention and Remedy. 1892. Crown 8vo, price $6 d$.

NOTES AND DESCRIPTIONS OF A FEW INJURIOUS TARM AND FRUIT INSECTS OF SOUTH AFRICA. With Descriptions and Identifications. of the Insects, by OLIVEr E. JAxson, F.E.S. (This work contains the Second Edition of Observations on Australian Bug (Icerya Purchasi), the First Edition being out of print. Crown 8vo, price 2s. 6i.

SIMPKIN, MARSHALL, HAMILTON, KENT \& CO. Stationers' Hall Court, London. 




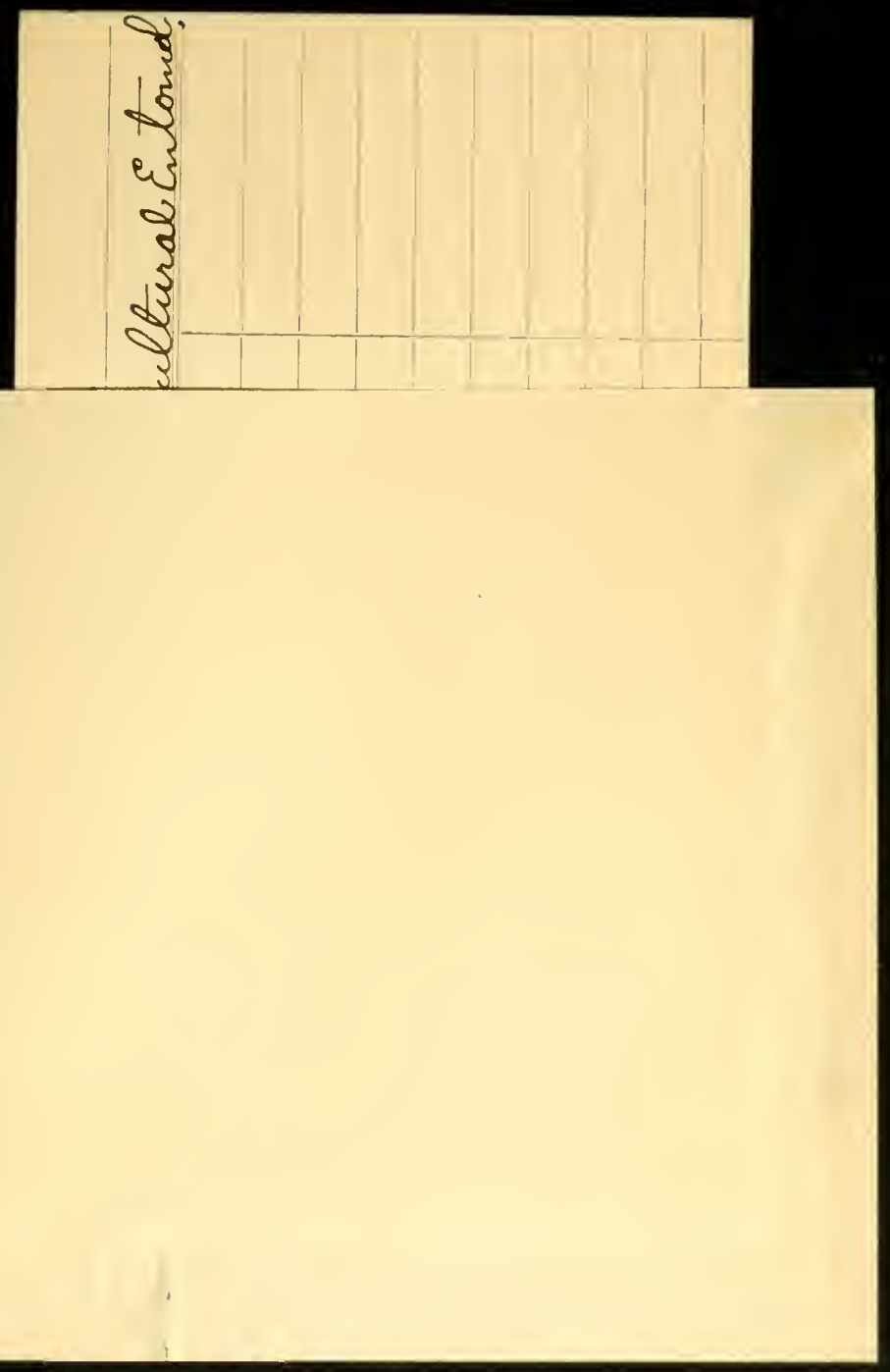


SMITHSONIAN INSTITUTION LIBRARIES

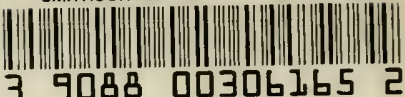
nhent SB931.073t

A text-book of agricultural entomology 